PUdLICATIOIJ 964 June, 1956

RANGE FORAGE PLANTS OF

THE CAIJADIAN PRAIRIES

J. B. CAMPBELL, K. F. BEST and A. C. BUDD

630.4

C212

P 964

1956

c. 3 


\section{9}

\section{RANGE FORAGE PLANTS $\mathrm{OF}$}

\section{THE CANADIAN PRAIRIES}

by

J. B. CAMPBELL, K. F. BEST and A. C. BUDD

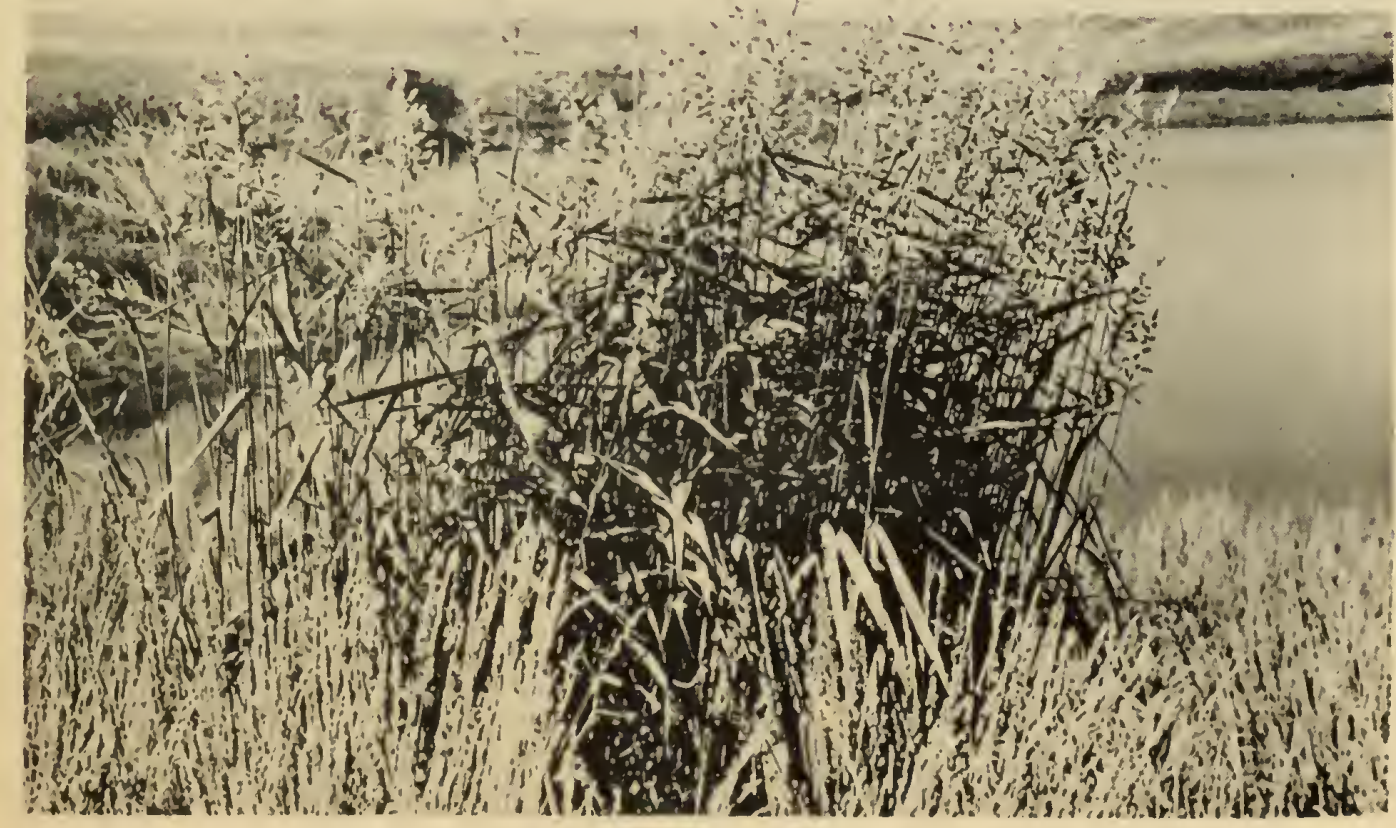

REED CANARY GRASS AND SLOUGH GRASS ON MARGIN OF POND

CANADA DEPARTMENT OF AGRICULTURE

OTTAWA, ONTARIO

630.4

$+\mathrm{C} 212$
$\mathrm{P} .964$

c. 2 


\section{TABLE OF CONTENTS}

\section{INTRODUCTION}

\section{GRASSES}

ALKALI GRASS

BLUE GRASSES

Canada Blue Grass

Canby Blue Grass

Early Blue Grass

Kentucky Blue Grass.

Sandberg's Blue Grass

BLUESTEMS

Big Bluestem

Little Bluestem.

BLUE GRAMA GRASS

BROME GRASSES

Awnless Brome Grass

Downy Brome Grass

Fringed Brome Grass

CORD GRASSES

Alkali Cord Grass

Prairie Cord Grass

FESCUES

Bluebunch Fescue

Creeping Red Fescue

Rough Fescue

Tall Fescue

INDIAN GRASS

INDIAN RICE GRASS

JUNE GRASS

MAT MUHLY

NUTTALL'S SALT-MEADOW GRASS

OAT GRASSES

Hooker's Oat Grass

Parry Oat Grass

Purple Oat Grass

Wild Oat Grass

ORCHARD GRASS

PERENNIAL RYE GRASS

AEDTOPS

Redtop

Rough Hair Grass

REED GRASSES

Marsh Reed Grass

Northern Reed Grass

Pine Reed Grass

Plains Reed Grass

$\begin{array}{cc}\text { Plate } & \text { Page } \\ A \text { and } B & \text { v-vi-vii }\end{array}$

28

28

50

50

49

51

52

53

49

51

52

53

11

11

12

15

15

17

17

18

18

16

57

57

58

58

34 
REED CANARY GRASS .

Plate Page

$46 \quad 46$

SAND DROPSEED

SAND GRASS

$23-23$

SLOUGH GRASS ...........................................

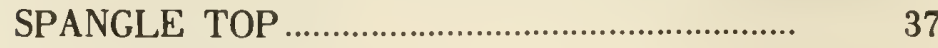

SPEAR GRASSES

Common Spear Grass .............................. $60 \quad 60$

Green Needle Grass ............................... 63.63

Porcupine Grass .................................... 61

Western Porcupine Grass ........................ 62

SWEET GRASS .............................................. 39

SWITCH GRASS ........................................... 45

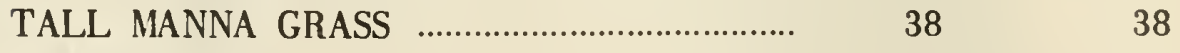

TIMOTHY

Alpine Ti mothy ................................... 47

Timothy ................................................ 48.48

TUFTED HAIR GRASS .............................. 27

WHEAT GRASSES

Awned Wheat Grass ................................. 8

Crested Wheat Grass ............................... 1

Intermediate Wheat Grass ...................... 4

Northern Wheat Grass............................... 2

Quack Grass ......................................... 5

Slender Wheat Grass................................. $\quad 7 . \ldots$

Tall Wheat Grass ................................... 3

Western Wheat Grass ................................ 6

WILD BARLEY

$40 \quad 40$

WILD RYE GRASSES

Hairy Wild Rye ....................................... 30

Nodding Wild Rye ..................................... 29

Russian Wild Rye ................................... 31

Virginia Wild Rye ................................... 32

SEDGES AND RUSHES

Awned Sedge

Baltic Rush

Beaked Sedge ........................................ 67

Low Sedge

Spike Rush

Thread-Leaved Sedge

SHRUBS, TREES, AND OTHER HERBS

Alfalfa

Aspen Poplar.

Asters

Clovers

Sweet Clover

True Clovers

Common Hawkweed.

Dandelion.

Fireweed 
TABLE OF CONTENTS - Concluded

\begin{tabular}{|c|c|c|}
\hline \multirow{2}{*}{\multicolumn{2}{|c|}{ SHRURS TRFFS AND Plate }} & \multirow[t]{2}{*}{ Page } \\
\hline & ed & \\
\hline 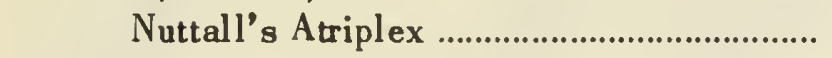 & 75 & 75 \\
\hline 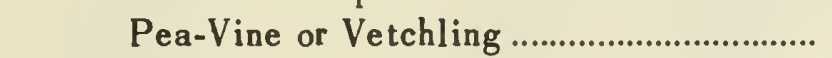 & 82 & 82 \\
\hline Ragwort & 99 & 99 \\
\hline 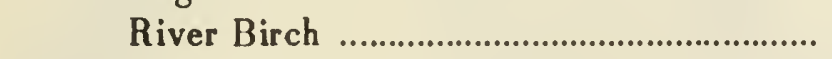 & 73 & 73 \\
\hline Roses & 79 & 79 \\
\hline Sages & & \\
\hline 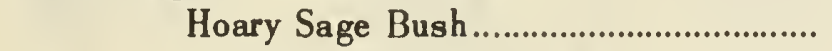 & 92 & 92 \\
\hline Pasture or Fringed Sage ...................... & 93 & 93 \\
\hline Saskatoon & 77 & 77 \\
\hline 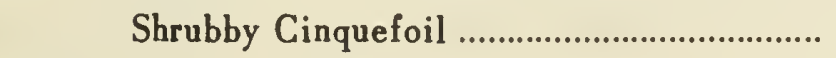 & 78 & 78 \\
\hline 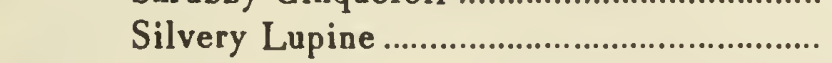 & 83 & 83 \\
\hline 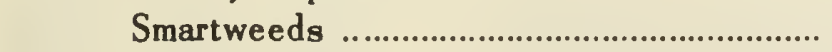 & 74 & 74 \\
\hline 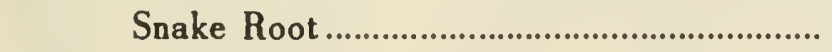 & 90 & 90 \\
\hline 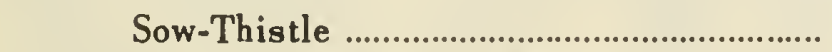 & 97 & 97 \\
\hline Star-Flowered Solomon's Seal ......................... & 70 & 70 \\
\hline Sweet Broom & 81 & 81 \\
\hline Sweet Cicely & 89 & 89 \\
\hline Vetch & 87 & 87 \\
\hline Willow & 72 & 72 \\
\hline Winter-Fat & 76 & 76 \\
\hline
\end{tabular}


Digitized by the Internet Archive in 2012 with funding from

Agriculture and Agri-Food Canada - Agriculture et Agroalimentaire Canada 


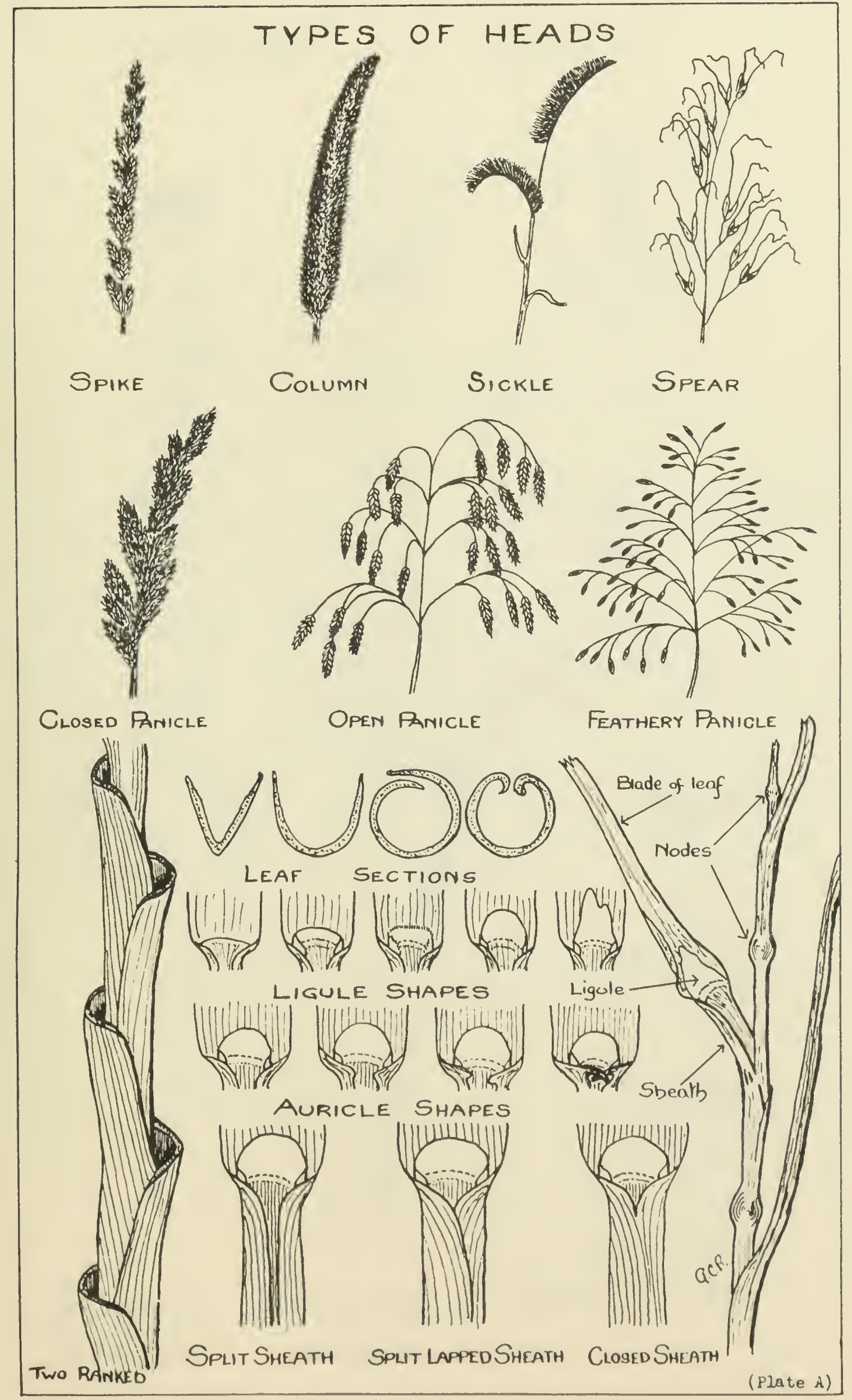





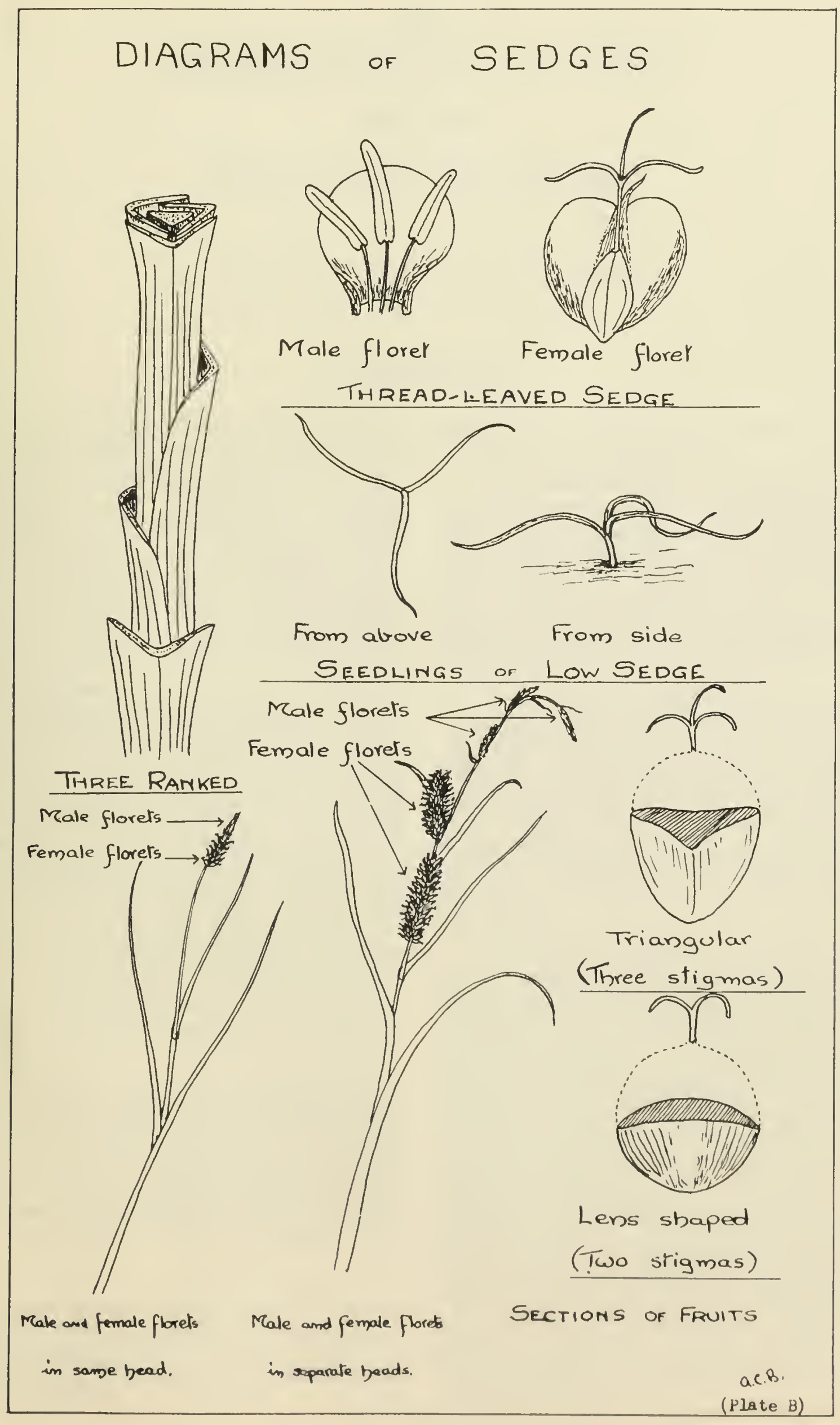





\title{
99 \\ RANGE FORAGE PLANTS \\ of the \\ CANADIAN PRAIRIES
}

\author{
J. B. Campbell ${ }^{1}$, K. F. Best ${ }^{2}$, and A. C. Budd ${ }^{3}$
}

\section{INTRODUCTION}

There are over $50,000,000$ acres of grass, shrub, and bush covered rangeland in the Prairie Area of Western Canada. This acreage produces most of the summer pasturage, as well as about 20 per cent of the winter feed supply for over $3,900,000$ cattle, 550,000 horses, and 500,000 sheep. The productivity of the rangeland is not high and varies considerably from district to district. More than 35 acres may be required to grow enough summer feed for a cow in the driest portions while less than 3 acres will be sufficient in the most favored spots.

The 50,000,000 acres used for range are enclosed by a semi-circle whose base coincides with the International Boundary between Canada and the United States. Its western edge is close to the Rocky Mountains, while the Red River in Manitoba is close to its eastern boundary. The perimeter of the semi-circle follows the Foothills of the Rocky Mountains, thence to Edmonton, Cold Lake, Meadow Lake, Nipawin, Lake Manitoba, and the Red River. Range is only one of the several forms of land utilization within this region as acres devoted to dryland farming, irrigation, and forest reserves occupy about 60 per cent of the land area. In this bulletin, the region described is called the "Prairie Area".

Over 1500 species of native plants have been collected within the Prairie Area, although few are abundant and even fewer are palatable to livestock. Within any district, four or five grasses may provide 90 per cent or more of the grazing supply, while a single grass may provide as much as 75 per cent of the forage in small sections. Thus, although there are

1. Officer-in-Charge, Pasture Division, Experimental $\mathbf{F}$ arm, Swift Current, Saskat chewan.

2. Range Ecologiat, Pasture Division, Experimental Farm, Swift Current, Saskatchewan.

3. Range Botanist, Pasture Division, Experimental Farm, Swift Current, Sakkat chewan. a large number of plant species, very few are of importance to the livestock industry.

The plants selected for inclusion in this bulletin comprise grasses, sedges, rushes, shrubs, and trees. They include those species which provide the bulk of the pasture supply, although a few others may have local importance. The habitat, growth characters, nutritive values, palatability, reaction to gruzing, and drought tolerance of each are described, while line drawings are added to aid identification.

\section{Grasses}

Of all the known plants, grasses are the most important livestock food. In addition they have many other uses as their seed and juices have been important items in human diets for many centuries, while their stems, roots, and leaves have provided fuel, thatch, and fiber for homes and industry since the dawn of civilization. One of their most important functions is to protect the soil against wind and water erosion.

As food for livestock, grasses are handled in several fashions. Pasture is undoubtedly the most common and cheapest method of utilization, although in northern districts grass used in the form of hay may have equal importance. The usefulness of grass silage has been realized for many years and today it is becoming a common method of preserving grass throughout North America and Europe. In many tropical and semi-tropical lands it is not uncommon to cut grass and feed it fresh to livestock; under the best growth conditions, this type of management will produce enough on one acre to feed four ur five mature cattle. Drying young grass, followed by pelleting or compressing is a recent development which preserves feed quality and provides high protein supplements. This grass is a versatile crop which can be handled in several fashions to provide food for either growing or mature livestock. 
Although there are over 30,000 different kinds of grasses throughout the world, nevertheless they all have common characters which distinguish them from other plants. Grasses have hollow or occasionally pith-filled stems which are divided into sections by nodes or swellings. The leaves have two parts, the sheath and blade; the sheath encloses the stem, while the blade is free. The leaves grow in two ranks, pairs being on opposite sides of the stem. Grass seeds are enclosed in chaffy covers which may be free as in wheat or which may cling as in oats. In addition there is an outer seed covering known as glumes which may enclose one or several seeds; these usually remain on the plant after the seed drops off. Several of these distinguishing characters are presented in Plate $\mathrm{A}$ and reference to the illustrations will assist to identify different grasses.

Over 140 different grasses have been reported growing in the Prairie Area. Certain of these are associated with specific growth conditions. Blue grama grass is associated with the dry central region and is seldom encountered elsewhere. Rough fescue is the distinguishing grass in the association growing in the Foothills and Cypress Hills. The bluestems are dominant in Manitoba, but are seldom collected west of the third Meridian. Thus, each district has a few important species which produce the bulk of the forage and whose growth characters determine local pasture management practices and carrying capacities.

Although most of the grasses described in this bulletin are native range plants, a few of the common cultivated species are included. These are the few which have been used successfully in grassland farming programs on different soils and under different climatic conditions within the Prairie Area.

\section{Sedges and Rushes}

Sedges and rushes are grass-like plants in that many species produce long, narrow, flat basal leaves, as well as a few stem leaves. However, they can be distinguished from grasses by a few simple characters including their solid stems without nodes, closed basal sheaths, and three-ranked leaves. A few of the distinguishing characters are shown diagramatically in Plate B.

The sedge family includes a large number of different species, in fact it is one of the largest in the plant kingdom. The species have a wide distribution also as they are abundant in both the north and south temperate zones, fairly common in tropical regions, while a few hardy members are found north of the Arctic Circle and in high mountain parks.

There are many different sedges growing throughout the Prairie Area. Plant lists prepared by the
Universities of the Prairie Provinces show over 100 different species. Many of these are rarely collected, some are associated with very specific growth conditions and are seldom encountered, while a few are common both on dry upland and in sloughs. Certain sedges are very palatable to livestock and will be grazed out quickly if not managed properly. A few are so small that they cannot be grazed by cattle, while at least one sedge spreads under heavy pasturing and thus is an indicator of an overgrazed condition. All sedges found in the Prairie Area have creeping rootstocks. These may produce stems and leaves at very short intervals and thus appear to have a bunch grass habit of growth, or the rootstocks may send up stems at widely spaced intervals, each appearing to be a separate plant. However, most species send up stems at distances of 1 to 4 inches and produce fairly dense cover resistant to erosion.

The flower parts of sedges vary considerably. Certain species have very simple flower structures with all floral parts enclosed in a single spike at the top of a short stem. Threadleaf sedge or niggerwool is an example of this type. Others, including beaked sedge, have two types of spike on each plant, the male flowers grow on a narrow structure at the tip of the stem while the female flowers are found in a thick spike in the axils of the leaves. A few species have male and female flowers on different plants.

Chemical analyses of sedges indicate similar compositions to those of grasses, although protein, fats, and digestible starches and sugars are usually higher, while crude fiber and ash contents are generally lower. At least two species cure on the stem. Sedges usually make nutritious and palatable but light weight hay.

Members of the rush family are grass-like plants also. However, their stems are usually smooth, shiny, leafless, cylindric, and filled with pith. Small perfect flowers grow near the ends of the stem and mature into three-celled capsules containing from one to many brown seeds. The technical name Juncus is derived from the Latin "jungo" (meaning to bind) and refers to the use of these plants as a binder in basket making. The family has two distinguishing characters, the flower cluster which appears to come from the side of the stem and the long leaf which continues from the point where the flower cluster emerges.

\section{Shrubs, Trees, and Other Herbs}

Although grasses and sedges provide by far the largest portion of the pasture supply, shrubs, trees, and other herbs may be grazed to a considerable degree and add fodder as well as specific nutrients to the ration. 
As a group trees, shrubs, and other herbs will total over 1400 species or nearly 90 per cent of all plants collected in the Prairie Area. Some of these are very rare, others grow only in small districts, many occur with certain plant associations, while a few are found everywhere.

Very few of the 1400 or so shrubs, trees, and other herbs are valuable forage plants. Over sixty will have poisonous properties and are a menace to livestock health. Several hundred will be so small and sparse that they are useless or, if eaten, contribute little to the fodder supply. A few, such as cactus, can cause physical injury to grazing animals. Others, such as trees, provide browse only when young, while a great number are just unpalatable. However, a few are sufficiently abundant and palatable to warrant them being classes as forage species.

Just why certain forage herbs (forbs) and certain browse plants are eaten readily is difficult to understand. They are classed as palatable because livestock can be observed eating them and in many cases with apparent relish. It is easy to understand why succulents like alfalfa, pea-vine, and dandelion are readily grazed, but the desire of livestock for willow, poplar, winter-fat, salt sage, and roses must be for other reasons. Earlier observations indicated that animals sought such species for their medicinal value. However, information available today suggests that these are eaten to secure specific nutrients, because chemical analyses reveal higher protein and phosphorus contents in the new growth of shrubs than in the associated grasses. This latter belief is substantiated further because greater utilization of forbs and browse plants is evident as nutrient contents of grasses decline.

However, broad-leaved plants do not replace grasses in livestock rations. In sparse stands, sages, roses, willow, poplar, and other species may be grazed out, but if their stands are even moderately heavy, these species may increase in abundance as grazing reduces the stands of grass. Thus, under two conditions of sparse or dense stands, a species may be rated highly as a fodder plant or as an aggressive range weed.

Only thirty broad-leaved species are described in this bulletin. They are among the most common as well as the most widespread. In addition to providing some forage, they act to resist soil erosion and on occasion their increasing or decreasing stands may be indicators of overgrazing. 



\section{CRESTED WHEAT GRASS}

\section{Agropyron cristatum (L.) Gaertn.}

Crested wheat grass was introduced into Canada in 1915 from Western Siberia. It adapted itself quickly and has been used for pasture and hay production, and to regrass abandoned and eroded land in the drier sections of the region. Although it grows well on all soils, its excellent response on sandy land indicates its particular suitability for that soil type. In the Foothills and Cypress Hills, as well as adjacent to the northern boundary of the area, it produces less than brome grass, timothy, or fescue.

Crested wheat grass is a bunch grass with dense roots which grow to a depth of 6 feet. Its leaf growth is rapid and steady from mid-April to late June, but ends by mid-July when the seed starts to ripen. Fall growth may occur during September. Highest yields are obtained from three- or four-year-old stands, after which yields are usually lower as stands become progressively sod-bound.

Because of its rapid growth during April and May, crested wheat grass either alone or with alfalfa makes excellent spring pasture. Further, it can be grazed heavily until mid-June without injuring the stand or reducing its long-time yielding capacity. Lighter rates of grazing can be practised throughout the summer. With alfalfa, and seeded in 12-inch rows, crested wheat grass makes excellent hay if cut before the end of June. It recovers rapidly from drought.

Crested wheat grass is palatable to all classes of livestock and particularly so during May and June. During these months its protein content will drop from about 18 to 10 per cent, with further decreases to about 5 per cent by October. In addition to satisfactory protein contents during the spring, the crop has a good nutritive balance between protein, carbohydrates, vitamins, and minerals.

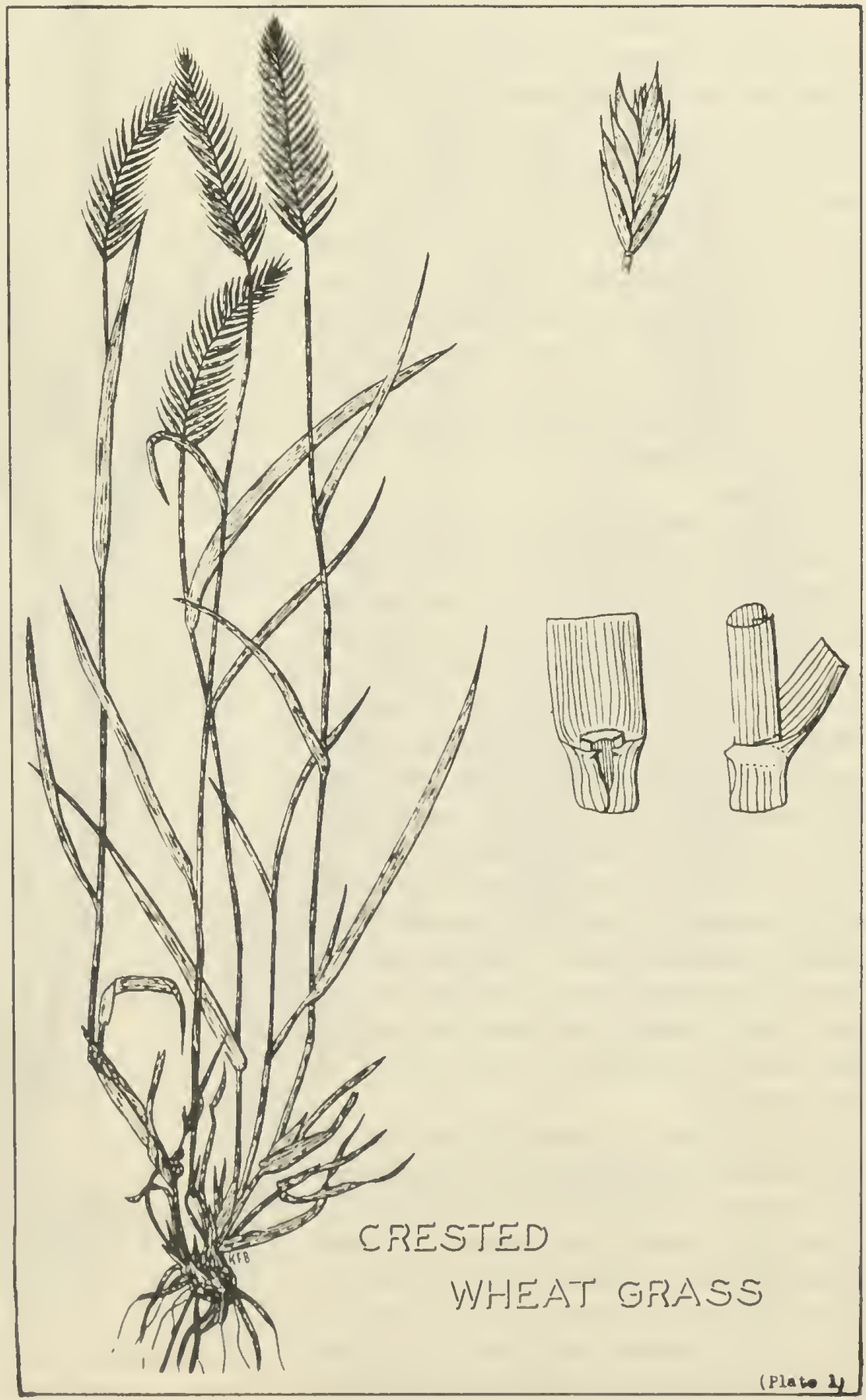

(Plate 1 ) 


\section{NORTHERN WHEAT GRASS}

Agropyron dasystachyum (Hook.) Scribn.

Northern wheat grass is similar to western wheat grass or bluejoint in growth habits and general appearance, but can be distinguished by the lighter green color and tufted appearance of the basal leaves, and the seed husk which is covered with fine hairs. It grows in mixed and sparse stands with bluejoint or spear grass on clay and loam soils, and occasionally in nearly pure stands on sandy land. It grows throughout the entire region and is considered a valuable forage plant. It is known also as thickspike, Yukon, and downy wheat grass.

Northern wheat grass is equipped with a three-way root system-creeping underground stems spread the plant and are sources of new stands, a very dense shallow root system that penetrates to a depth of about 10 inches takes advantage of surface moisture, a few deeper feeding roots may penetrate to a depth of two or more feet. This combination of root types, which feed and extend the stand, increases the tolerance of northern wheat grass to drought and its resistance to invading weeds. Dense stands of northern wheat grass seldom set seed, but individual plants will do so during years when growth continues for the 115 days required from date of first growth to seed maturity.

The plant is palatable despite its fairly coarse stem and harsh leaves. Chemi$c a l$ analyses indicate that its nutrient content follows the same pattern as other dryland grasses. Protein decreases from a high of 20 per cent in early May to about 4 per cent in October, while the energy producing el ements-fats. starches, cellulose, etc.-maintain a high level of about 45 per cent from emergence to maturity. The species cures on the stem

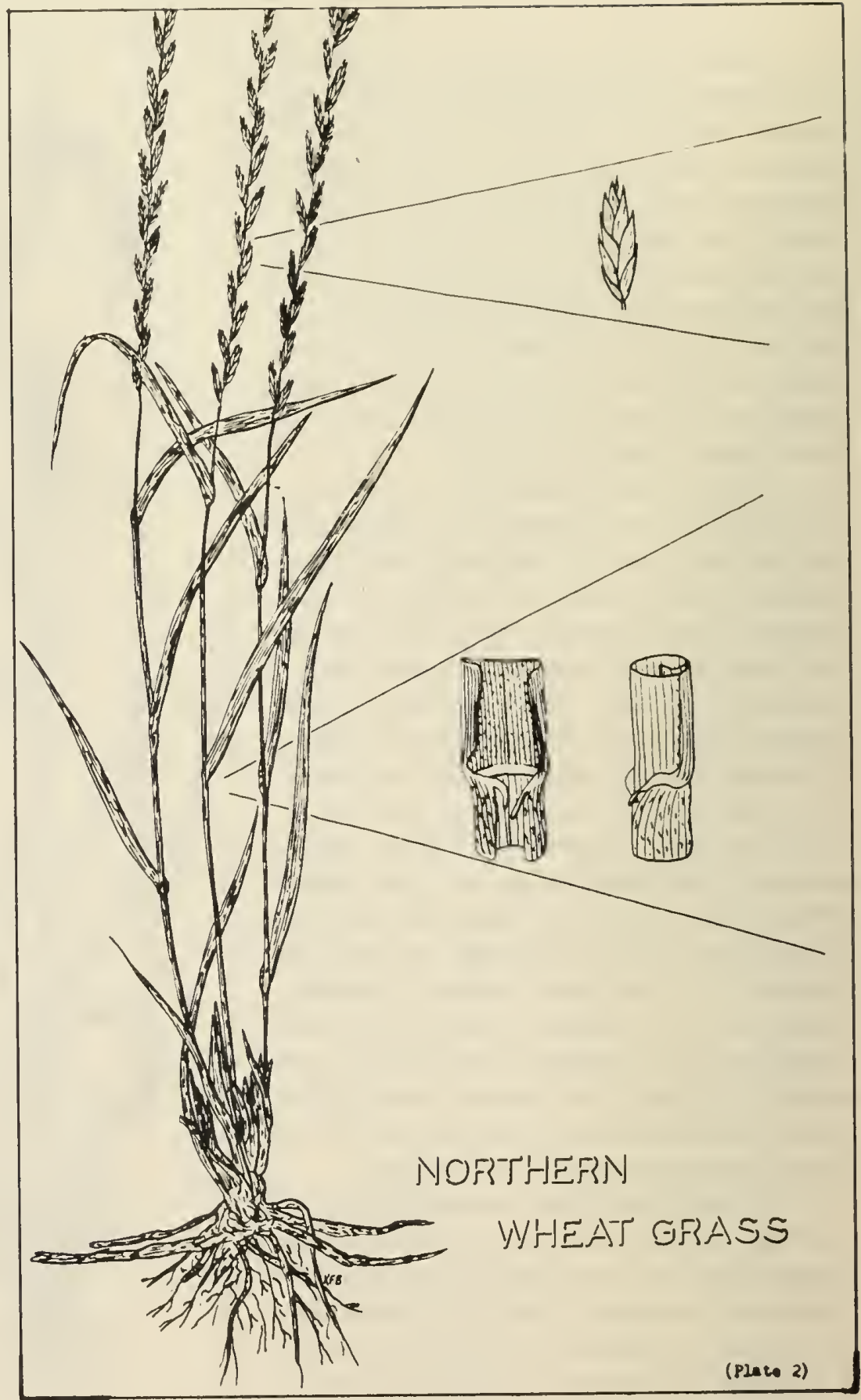

to produce palatable and nutritious winter pasture and hay. 
Agropyron elongatum (Host.) P.B.

Tall wheat grass is another of the zrasses introduced from Southern Russia. It has been grown in the Prairie Area since 1929 when it was introduced into Canada by the University of Saskatchewan. For many years it created little interest because it is coarse, not particularly drought tolerant, and slow to establish. However, recently it has demonstrated its ability to thrive in subirrigated, saline soil where wild barley is usually the dominant grass.

Tall wheat grass is a bunch grass that extends its size by producing tufts on short rootstocks at the edge of the mature plant. Long, coarse, light green basal leaves surround several 3-to 6-foot leafy stems. The spike is interrupted, that is the spikelets do not overlap as in bluejoint. Each spikelet has a character which distinguishes tall wheat grass from others in the group; the spikelets and the four to ten enclosed seeds grow away from the stem like a sickle. The seeds are large and heavy. The outer seed covering, the glumes, are square across their tops.

Tall wheat grass is more palatable than the coarse leaves and stems suggest. It is reported to be good pasture and excellent hay when cut shortly after heading. It yields well by itself or in mixture with alsike clover, despite the open spaces between the plants. Seed is harvested easily with a combine. Seeding in 12 -inch rows at a rate of 12 pounds per acre is recommended.

Tall wheat grass is a slow grower when young. However, it will fill in its stand by both new plants from seed and by extensions from mature plants. It has one other important character-it will establish and maintain its stand on moist moderately alkaline soils. It is more alkali tolerant than either brome or slender wheat

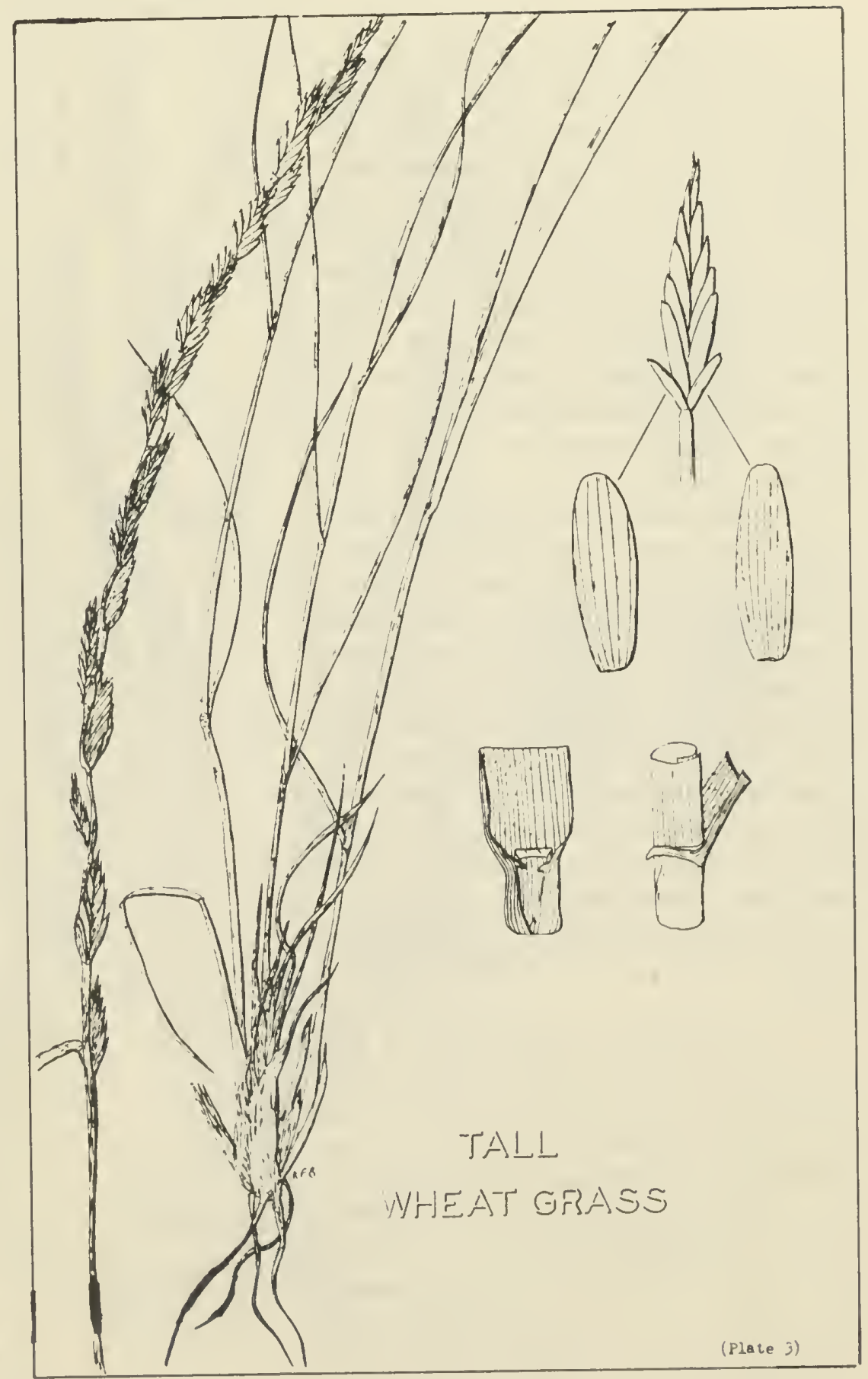

grass and nearly as much so as wild barley. It will not develop in dry alkaline sites, nor will it grow where the soil is so alkaline that native weeds cannol persist. 


\section{INTERMEDIATE WHEAT GRASS}

Agropyron intermedium (Host.) Beauv.

Intermediate wheat grass is a native of Eastern Europe which was introduced into the United States in 1932 and into Canada a few years later. It adapted itself quickly to a great variety of conditions in the western States where rainfall is greater than 15 inches annually. In the Prairie Area it has demonstrated its ability to maintain stands where brome or creeping red fescue do well. It is presently being studied by plant breeders to select high producing, as well as drought tolerant and winter hardy strains.

Intermediate wheat grass has a deep feeding root system, as well as extensive creeping rootstocks which form a tough sod. Considerable long, dark green, basal leafage surrounds 3-to 5-foot leafy stems which end in a long spike. The edges of a large number of the leaves have short hairs which helps to distinguish this grass from others closely related. The seed head consists of spaced spikelets, one at each node, each containing from two to six seeds nearly as large as oats. The glumes, that is the outer seed covering, are about onehalf the length of the spikelet and are pointed.

As intermediate wheat grass is new to many farmers and ranchers, few realize its potential value. It makes very palatable pasture in all seasons of the year. It has some curing property and usually makes a fall growth that is sought by livestock. By itself, or in alfalfa mixtures, it produces good yields of high quality, palatable hay. Seed crops are not heavy-200 to 300 pounds per acre but the tall stems and large, firm seeds make harvesting with combines relatively easy. Seed is available from most seed houses.

Information available suggests that intermediate wheat grass will be useful for pasture and hay in all districts throughout the Prairie Area where annual

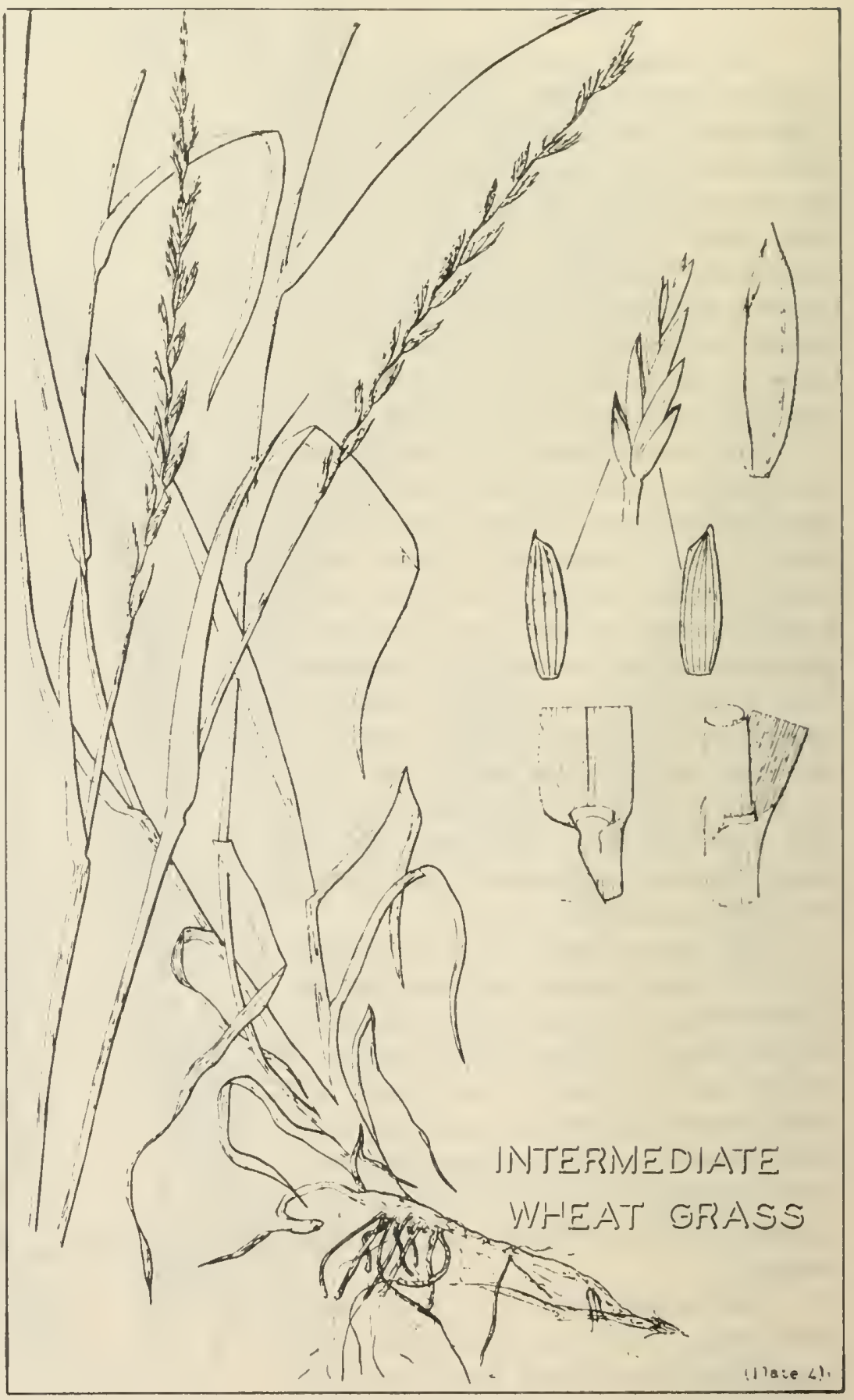

- precipitation exceeds 16 inches, or where the precipitation-evaporation is about unity. At present it is not recommended for the dry central area, except under irrigation. 


\section{QUACK GRASS}

Agropyron repens (L.) Beauv.

Quack or couch grass is an introduced wheat grass from Eurasia. It has established itself in the northern and eastern portions of the Prairie Area in hay fields, abandoned farms, and crop land. It requires considerable moisture to persist and thus has not invaded the dry central core of the region.

As with the closely related bluejoint, couch grass has a three-way root system. Scaly, yellow, creeping underground stems spread rapidly, while surface feeding roots fill the upper 18 inches with a dense mass of fiber; a few deeperfeeding roots grow to a depth of 8 or 9 feet. The leaves are green to yellowish-green, ascending close to the stem, and often spiralled. Compact heads with overlapping seeds produce heavy seed crops on all young or sparse stands. A sod-bound condition develops in three to five years after establishment and production declines accordingly.

This grass has a two-faced reputation. It is a noxious weed in cultivated fields, but a valuable hay and pasture grass wherever it has established itself in range land. Farmers generally regard it as one of the most difficult weeds to eradicate from wheat fields, whereas stockmen recognize it as palatable, digestible, and nutritious pasture during the spring and a strong hay for winter feeding. In addition to its forage quality, couch grass is a valuable soil binding plant to stabilize eroding land. Like other wheat grasses, couch grass cures on the stem. The few chemical analyses available indicate a similar protein trend to other

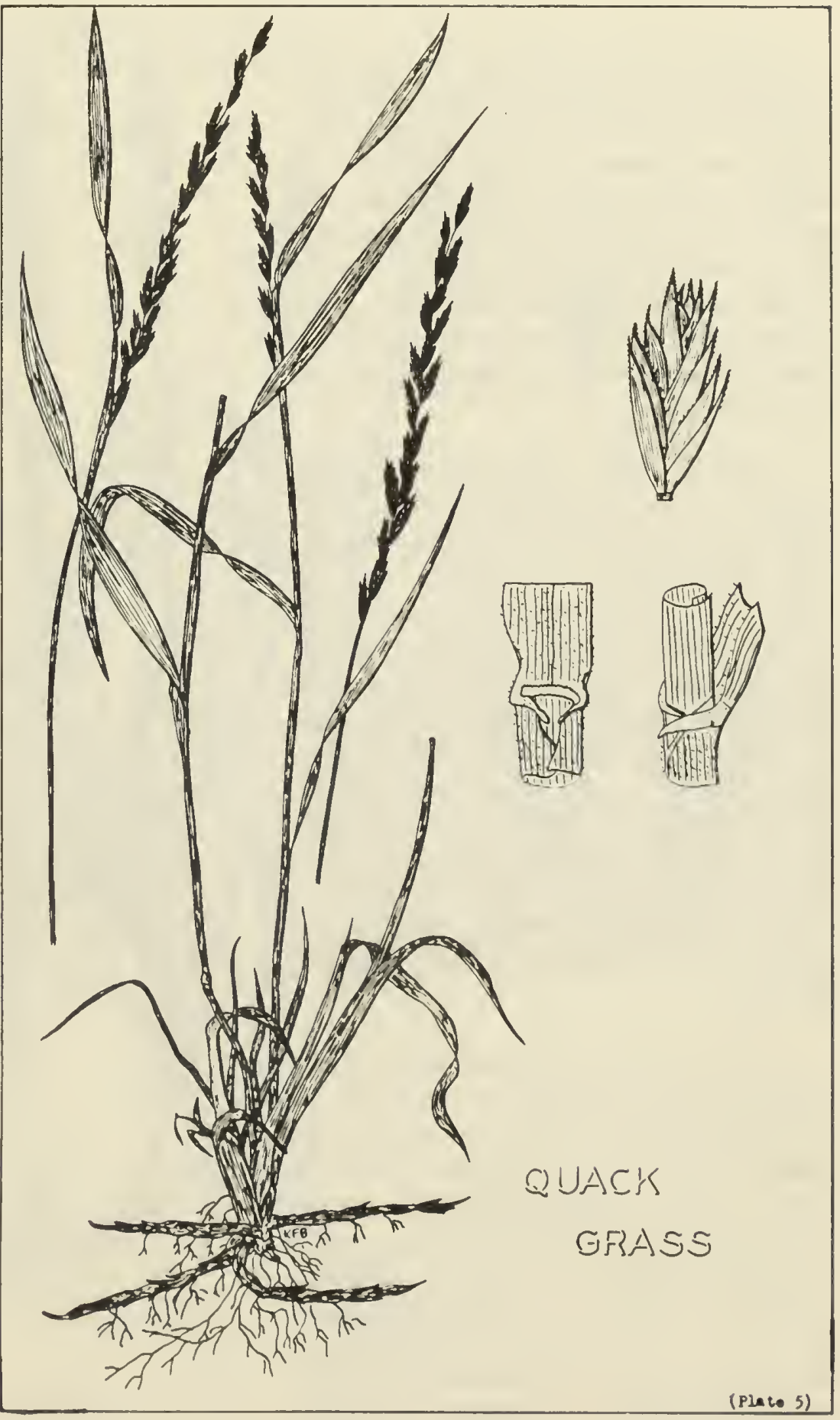
wheat grasses, but lower contents of energy foods and total nutrients. Two of its most useful characters for

range purposes are its early emergence and rapid spring growth. 


\section{WESTERN WHEAT GRASS OR BLUEJOINT}

Agropyron Smithii Rydb.

Testern wheat grass is known also as bluejoint, Colorado bluestem, western couch grass, and bluestem. It grows in fairly dense stands on clay soils in association with green spear grass, on saline soils with alkali-tolerant grasses and greasewood, and in sparse stands amongst blue grama grass and spear grass on upland sites. It is found throughout Western Canada from the Portage Plains to the west coast.

Western wheat grass leaves are rigid, blue-green in color, and grow at a 45-degree angle to the stem. The plant has creeping roots which assist to spread its stands. $\mathrm{Also}$, it has a well-developed root system to feed itself; not only do deep feeding roots penetrate to a depth of nearly 5 feet, but there is a mass of surface roots feeding to a depth of 8 inches. Thus the plant is well adapted to survive drought and to take advantage of light rains which only soak the surface horizon. Undoubtedly its three-way root system helps bluejoint to survive and produce during dry periods and to recover rapidly after prolonged droughts.

Western wheat grass is a fair yielder, producing about four times the yield of blue grama grass on upland and as much as 2 tons per acre on spring flooded sites. It rarely matures seed and requires about 110 days of growth for seed to ripen after its leaves emerge about May 1. Despite its rather harsh leaves, it is fairly palatable, nutritious, and digestible. Like many other range grasses, it cures on the stem. Chemical analyses indicate a protein content of 18 per cent in early May which declines to about 4 per cent by October; digestible carbohydrates increase their content from about 40 per cent to 50 per cent during the same period. Bluejoint is the standard

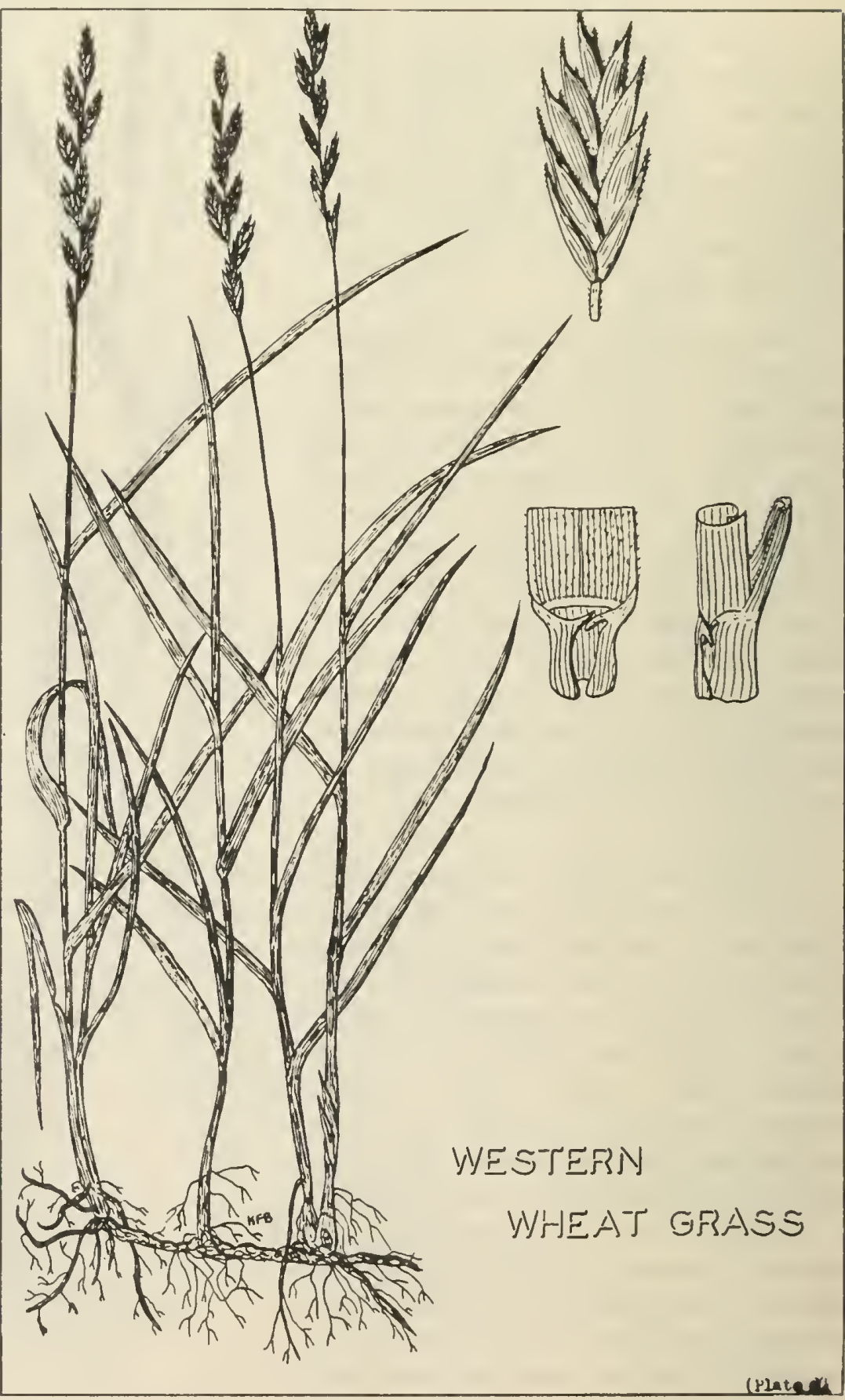

of quality for range hay and few, if any, native grasses equal it for this purpose. Feeding'tests have demonstrated that well-cured hay cut in the late leaf stage will have a 60 per cent digestibility. 


\section{SLENDER WHEAT GRASS}

Agropyron trachycaulum var. typicum Fern.

Slender wheat grass, also known as western rye, is a native of Southern Canada and Northern United States. It makes excellent growth on moist, well-drained soils, and has some alkali and drought tolerance. Unlike most other wheat grasses, its plants have a short life, seldom over five years.

Slender wheat grass has a leafy bunch habit of growth, with dense fibrous roots extending to a depth of 18 inches. It has no creeping roots, although two- or three-year-old plants may increase their basal area by tillering. The seed stalks are erect, with spikes which are either dense or very open. A relatively consistent character is the reddish or purple color of the stems near the base. Short awns extend from the seed hulls.

Slender wheat grass yields well for its first three or four years of growth. It is fairly palatable and nutritious in all stages of maturity, while its seed is sought by livestock in the autumn. Chemical analyses indicate that it has a well-balanced nutrient composition. Heavy grazing reduces stands quickly, allowing them to be invaded by weeds.

Selections of slender wheat grass have been grown as cultivated grasses throughout Canada. Because it develops its stands quickly, it has been used in rotation with annual crops and in mixtures with slower-developing but longer-lived grasses. It grows well with alfalfa, but soon disappears from a stand which contains crested wheat grass or couch grass. As a cultivated crop it is better adapted to the northern and eastern sections of the area than the dry central portion.

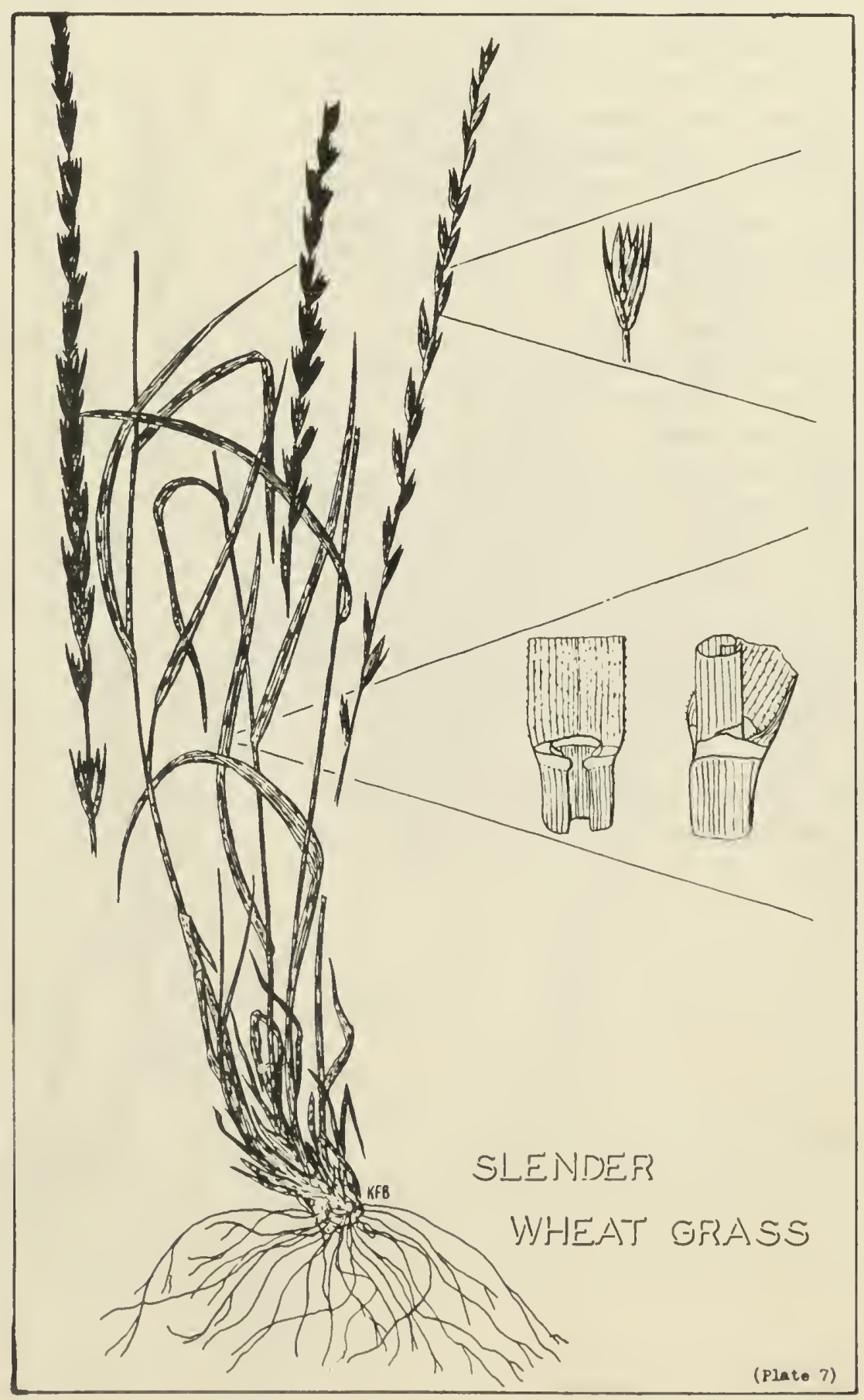


Awned wheat grass occurs throughout the range area. It is similar to slender wheat grass in growth characters, except its awns are longer and its seeds are clustered on one side of the spike. It prefers moist, well-drained, non-alkaline loam soils, and is more common in the western and northern portions of the area than in the dry central zone.

The basal leafage of the species is soft and very palatable to all classes of livestock. However, the stem and seed heads are rarely eaten. Thus, it is not uncommon to see single stalks, or two or three together, growing strongly in heavily grazed fields. The lack of palatability of the stalk and head ensures a supply of seed to establish new plants. As this species propagates itself by seed alone - since it possesses no creeping rootstocks - the non-palatable seed character is a fortunate one for range maintenance. It does not produce a desirable hay because of the lack of palatability of the straw and spikes.

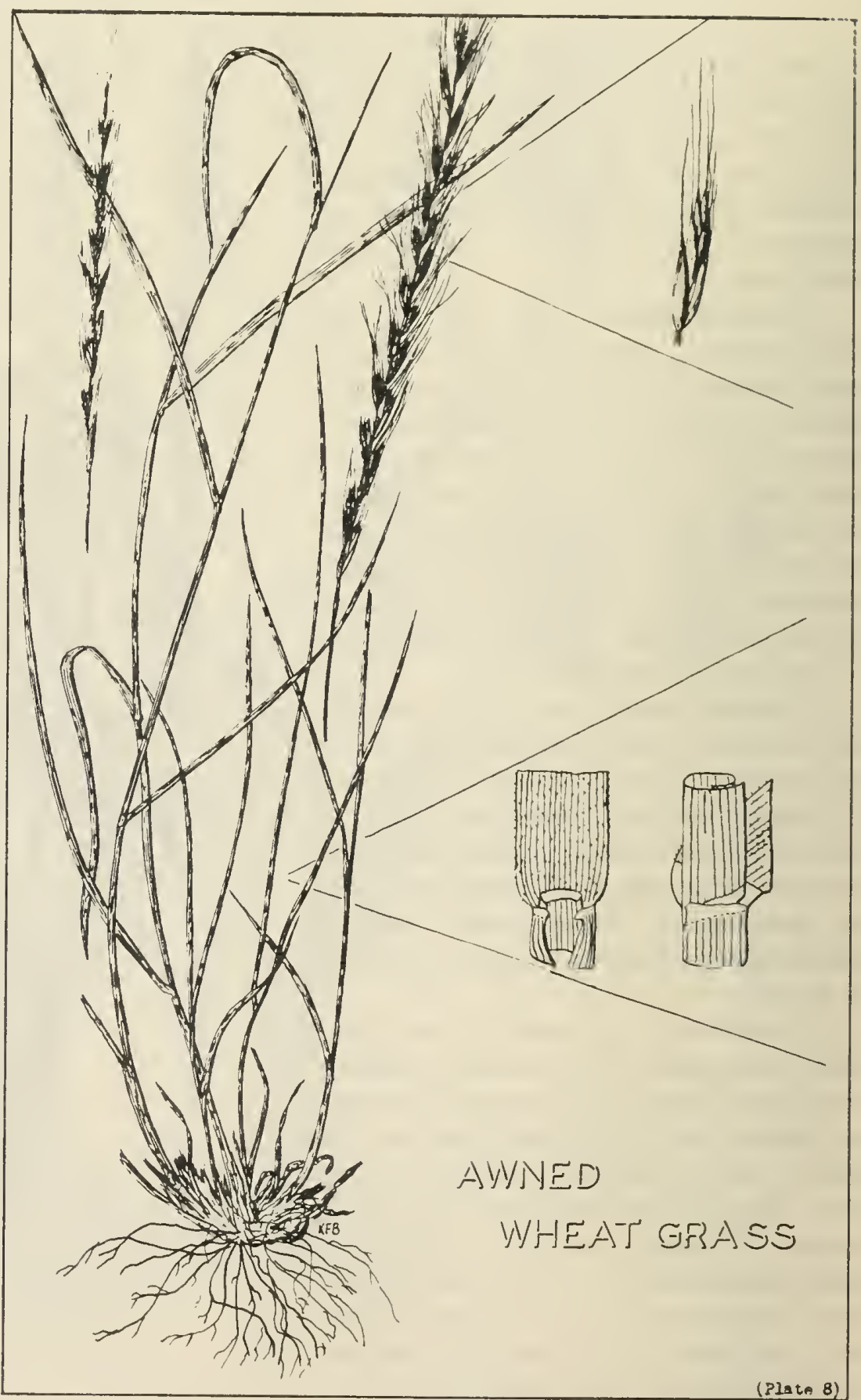




\section{REDTOP}

Agrostis alba L.

Redtop was imported from Europe in the days of early settlement and probably prior to 1750 A.D. It spread rapidly throughout North America and now is well-established wherever abundant moisture supplies are available. In the Canadian prairies this species often occupies slough edges between the upland grasses and the sedges growing in the water.

Redtop forms a dense turf. Short creeping roots spread its stand, while dense shallow feeding roots provide abundant nutrients. Its leaves are short and mostly basal. The spreading panicle bears many tiny reddish-colored flowers which have named the species. Small numerous hard seeds are matured early in summer.

Redtop appears to be less palatable than many reports suggest. Of all cultivated grasses, it is the least palatable for pasture, but can be used if kept grazed so that stem development is retarded. Reports indicate some palatability as hay, varying from fair to good. Chemical analyses show a satisfactory nutrient balance when grown on good soils. In general, it is the least productive of all cultivated hays. However, it grows on poor wet soils where few other grasses will persist, and is an excellent soil binder wherever it grows.

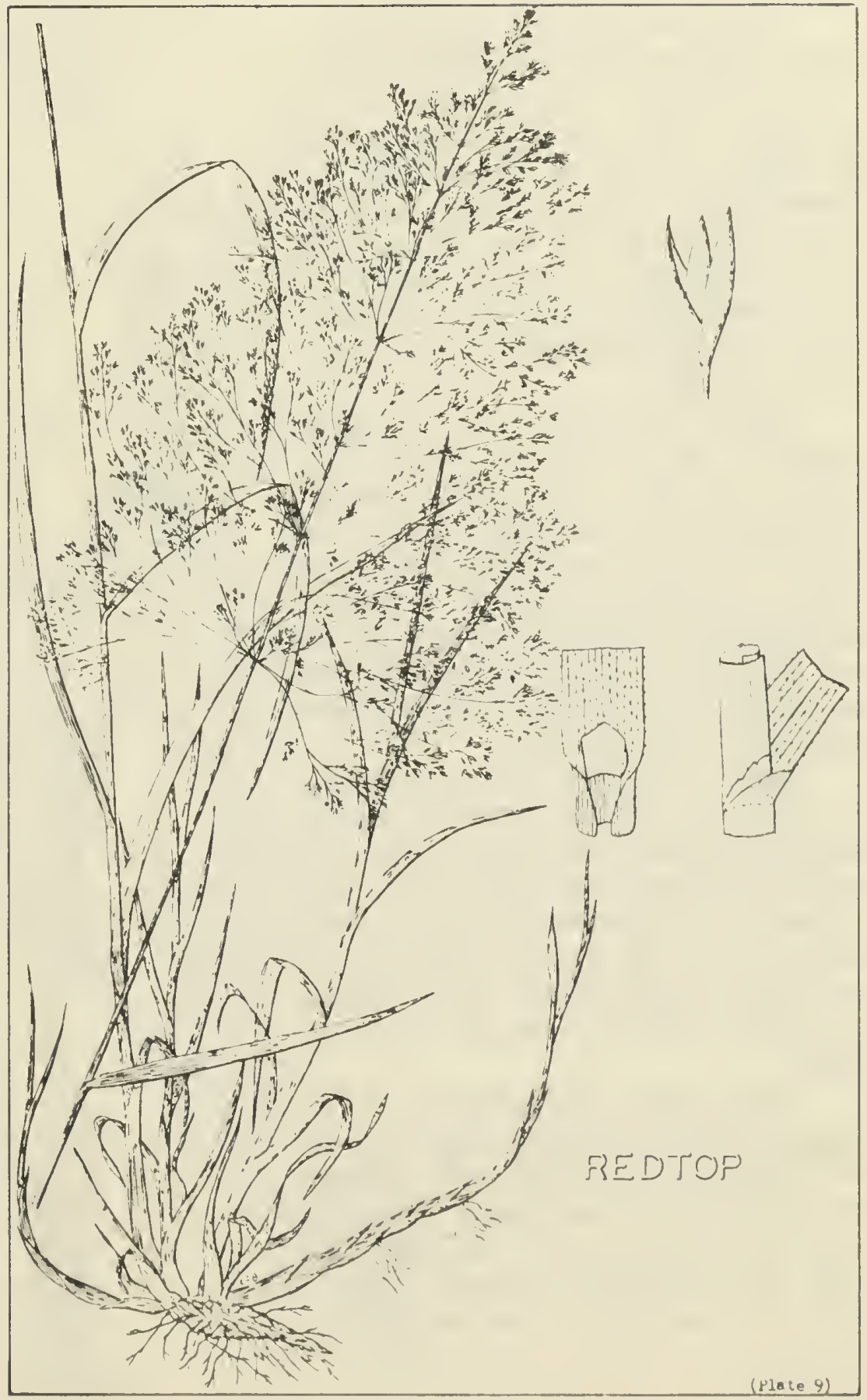




\section{ROUGH HAIR GRASS}

Agrostis scabra Willd.

Rough hair grass is a member of that group of grasses known as redtop, in fact it is often called winter redtop as well as tickle grass. It has a widespread distribution throughout Canada and the United States. It prefers to grow on moist. well-drained soils. In the Prairie Area only waste places, dry sloughs, roadsides, and abandored land support its existence. It is one of the first grasses to show green in the spring.

Rough hair grass is a short-lived perennial with a fibrous shallow root system and short leaves, both growing from a crown. Its seed stalks are from 8 to 18 inches tall and are topped with a large finely branched panicle. When walking through a stand the panicle may break off and creep up inside one's trousers. The panicle may be broken off and tumble across fields before strong winds.

Plants of rougn haur grass emerge in mid-April and make a leafy growth. Heads emerge from the sheath in late June and mature seed from late July to midAugust. By September the plants will have dried up, but can still be recognized by the small, straw-colored clumps dotting abandoned fields, dry sloughs, and waste places.

Only during April and May is this plant palatable to livestock. Nothing will eat it after the shot-blade stage, although the basal leaves may remain green and nutritive until late July. Its only other value is its ability to colonize denuded soils, thus assisting to prevent erosion.

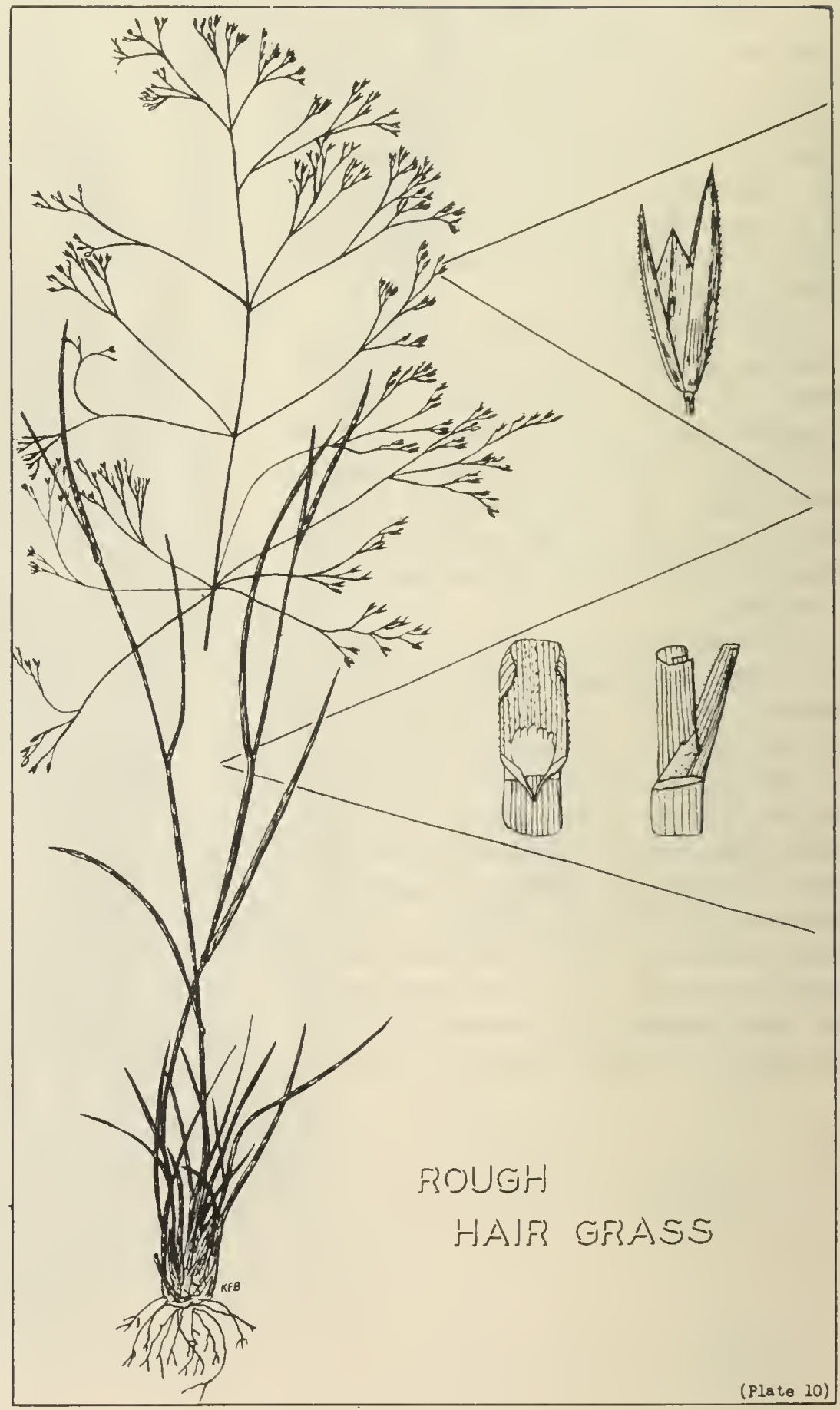


The North American home of the bluestems surrounds the Gulf of Mexico. A few species extend their ranges up the Mississippi River system and the east and west coasts, but only two appear north of the International Boundary. The generic name "Andropogon" is derived from two Greek words, Andros (man's) and pogon (beard), and refers to the long white hair contained in the head.

Big bluestem, bluejoint turkey foot, or northern beard grass grows on the eastern part of the Prairie Area. Heavy stands occurred in the days of first settlement throughout the Portage Plains and the Red River Valley. Today relic stands occur in the same districts, as well as sparse stand along the Souris and Assiniboine Rivers, and less frequently in the surrounding uplands.

Big bluestem produces from one to many bluish-colored stems growing to a height of from 3 to 6 feet. These robust stems are filled with pith like cornstalks. Its heads have from two to six branches all arising from one point and somewhat resembling a turkey's foot. Numerous white hairs fill the spaces between the seeds and twisted awns extend from the seed husks.

Bigbluestem is nutritious and palatable. During days of early settlement in the Red River Valley, it produced a large portion of the pasture and hay supply. However, it was susceptible to grazing and its heavy stands disappeared as the grazing load increased, and more quickly as the land was brought under cultivation.

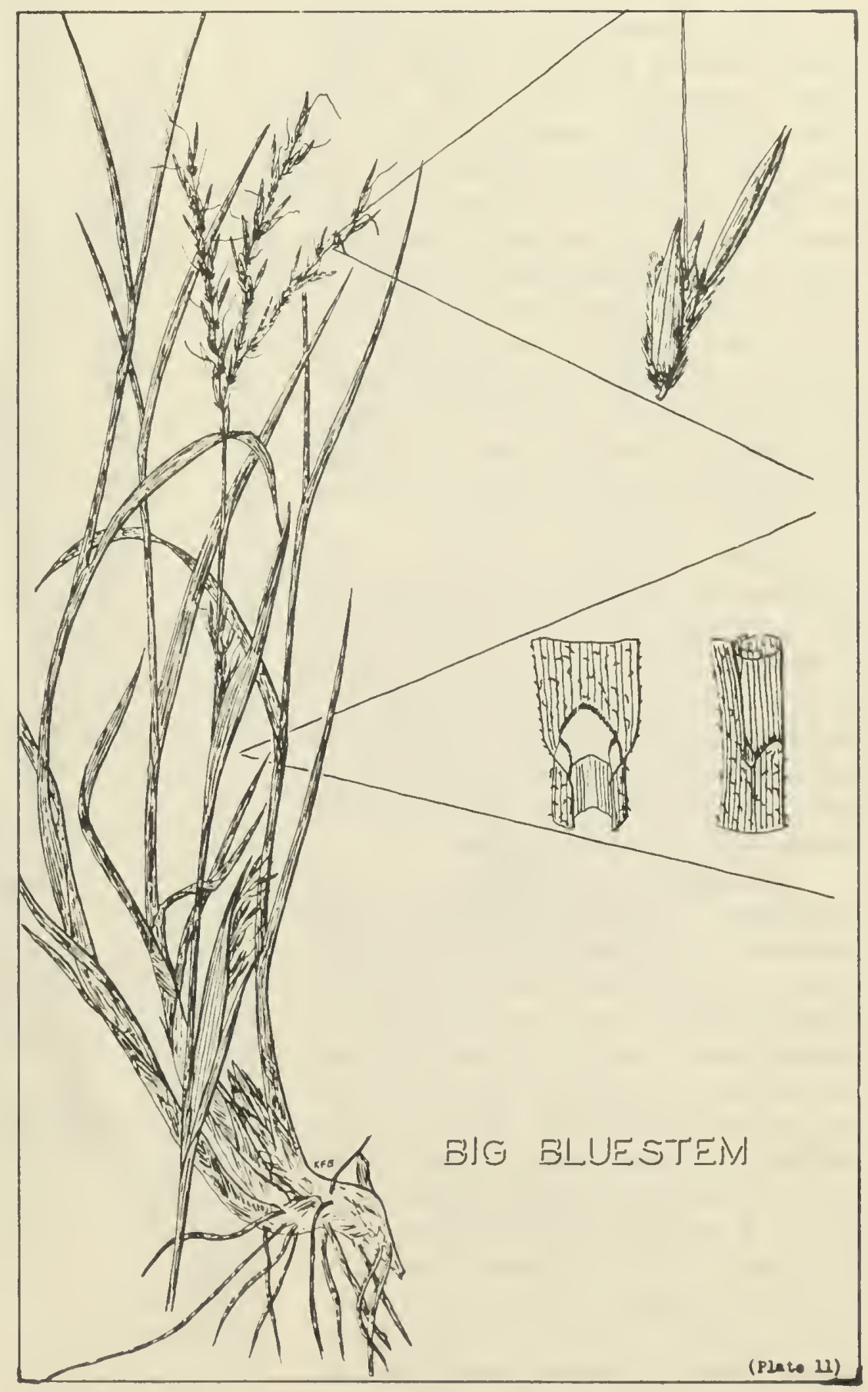




\section{LITTLE BLUESTEM}

Andropogon scoparius Michx.

Little bluestem has many common names including prairie and brown beard grass, broomsedge, and small feather grass. Its range extends from the Rocky Mountains to the Atlantic Coast, and from the Gulf of Mexico to Southern Yukon. Dense stands occur from the Interlake Area in Manitoba to the Manitoba-Saskatchewan Boundary, while small and sparse stands may be found throughout the balance of the Prairie Area on sandy and gravelly soils. It is fairly common in the Great Sand Hills, throughout the Missouri Coteau, and along the South Saskatchewan and Frenchman Rivers and Swift Current Creek.

Little bluestem is a bunch grass producing many pith-filled stems which may grow to a height of 2 feet. Numerous green or bluish hairy leaves grow from the crown to form a heavy mat in thick stands. A single branched panicle tops each stem and produces the hair covered and awned seeds typical of the bluestems. After frost the leaves will have a reddish tinge.

Although chemical analyses indicate satisfactory nutritive qualities, little bluestem is unpalatable except during the spring when its leaves are succulent and tender. After the boot stage this plant is seldom grazed, and as it does not cure but withers away in the fall, it has little to recommend itself for fall and winter pasture. Its protein content drops rapidly from a high of 14 to 16 per cent during midMay to 4 per cent by mid-August, and to still lower levels by October. Thus, at no time during its growth will it have a protein content equal to that of the high quality range grasses. In certain sandhill regions, it is considered to be not only worthless but a pest. Experience in the Interlake Region of Manitoba indicates

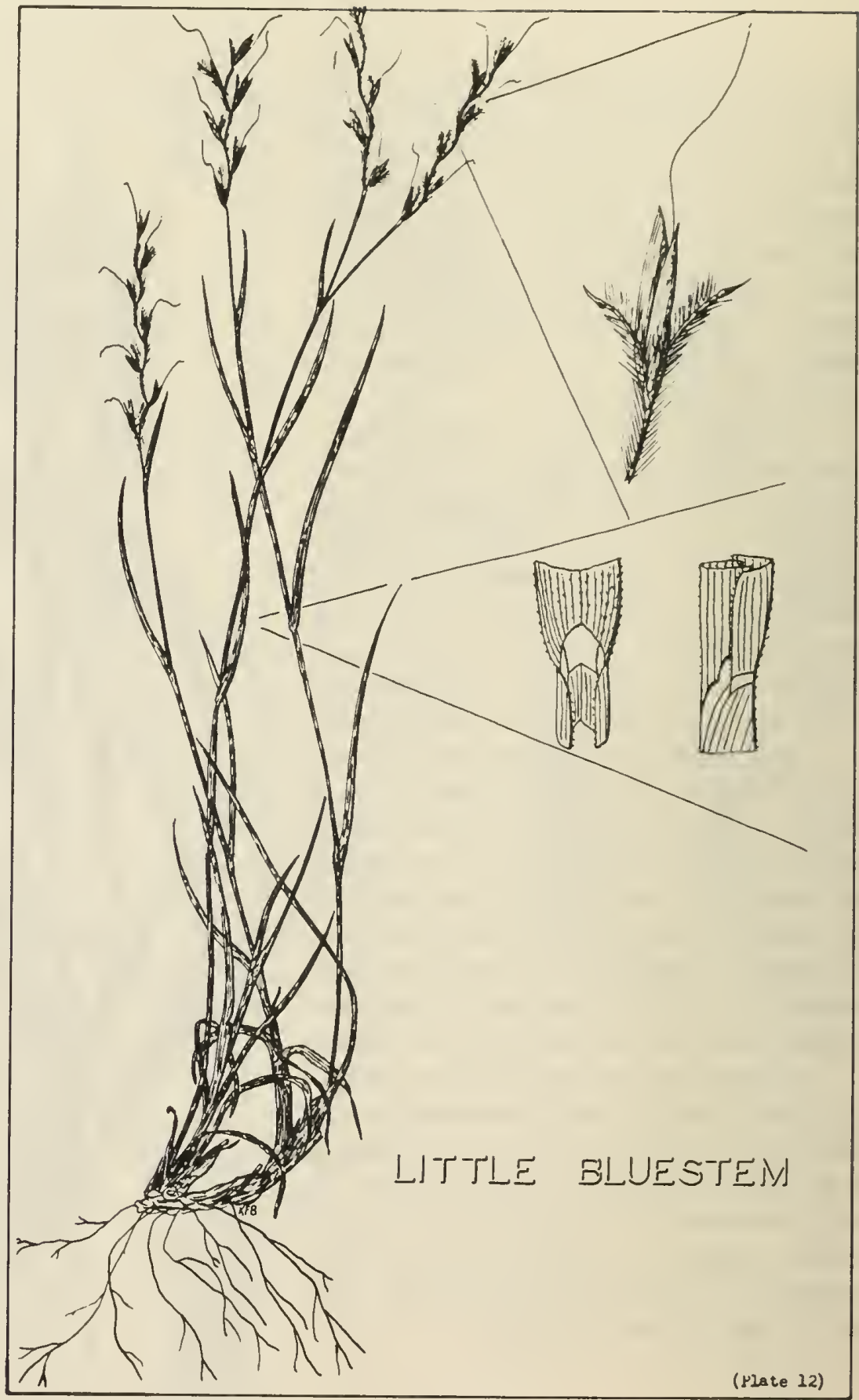

that it may be a valuable spring fodder, provided the old dry growth is burned off once every third or fourth year. 


\section{SPIKE OAT OR HOOKER'S OAT GRASS}

Avena Hookeri Scribn.

Spike oat is the only member of the Ivena or oat genus native to Canada, as all the others including the domestic and wild oat were introduced from Europe. Its range is limited also, as it occurs only on the eastern slopes of the Rocky Mountains, from Alberta to Manitoba, and southward to New Mexico. Further, it grows only where moisture is fairly plentiful as in the Foothills, Cypress Hills, Handhills, Neutral Hills, and the Parkbelt of Western Canada.

Spike oat is a bunch grass with shallow roots. The crown produces a mass of firm flat leaves and from one to several seed stalks, each of which will be topped with a panicle whose erect branches cling closely to the central column. A spikelet (group of flowers or seeds) consisting of from three to six florets terminates each branch. Hulls of the seeds are firm, shiny, and brown in color.

Seldom will spike oats grow in solid stands. Rather, single plants will be scattered among the associated species and will seldom account for more than 5 per cent of the stand. Thus it does not provide much forage and is not considered to be an important constituent of the rangeland cover. Chemical analyses reveal that its protein and mineral contents are equal to the best of the range species, and observations indicate that it is fairly palatable.

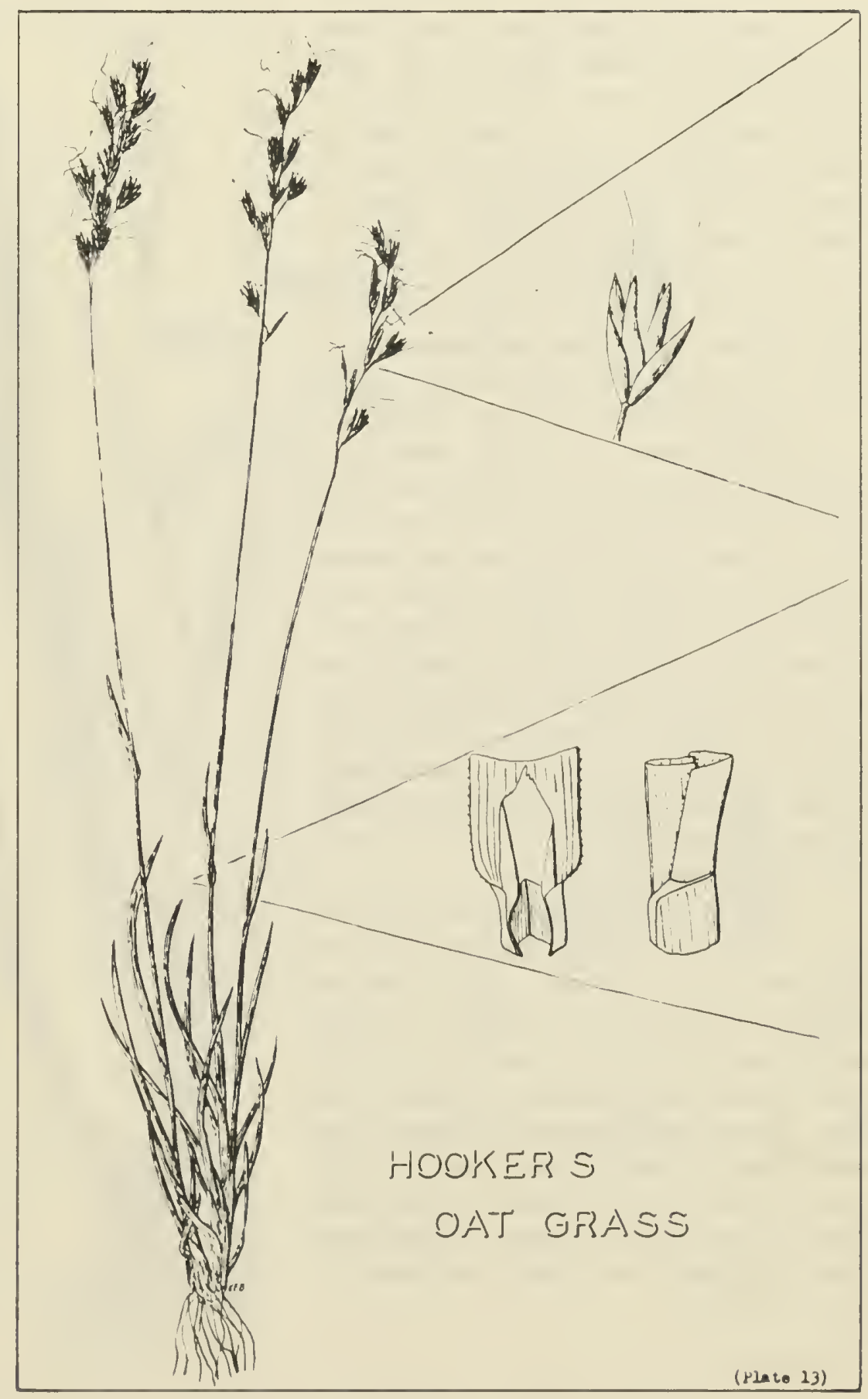




\section{SLOUGH GRASS}

Beckmannia syzigachne (Steud.) Fern.

Slough grass, American slough grass, or Beckmann's slough grass is the only species of the group which is found in North America. It is a common grass in shallow sloughs and marshes. It prefers a clay soil covered with a shallow layer of organic matter, and a sufficient depth of water to prevent the slough from drying before June 1 . Its range includes all of the United States except the southeast corner, all of Southern Canada, Alaska, and a considerable portion of Eastern Asia.

Slough grass is a stout annual. Its shallow roots support a leafy stem which may be three or more feet tall. A few basal leaves occur also, and in these an observer can see cross veins which cut the longitudinal veins at right angles to form rectangles. The branched head is classified as a closed panicle. Each branch will carry from one to four sickle-shaped spikes which produce from ten to thirty hard-coated seeds. The seeds can be stripped easily by drawing the head of the plant between the thumb and fingers.

Slough grass is palatable to cattle and horses from early stages of growth until the seed is nearly ripe. Chemical analyses indicate that nutrient elements are in good balance and that the seasonal protein trend is similar but slightly lower than that of upland grasses, dropping from about 14 per cent in early June to 5 per cent or less by mid-August. As with most grasses that grow in water, slough grass makes palatable and fairly nutritious but very light hay.

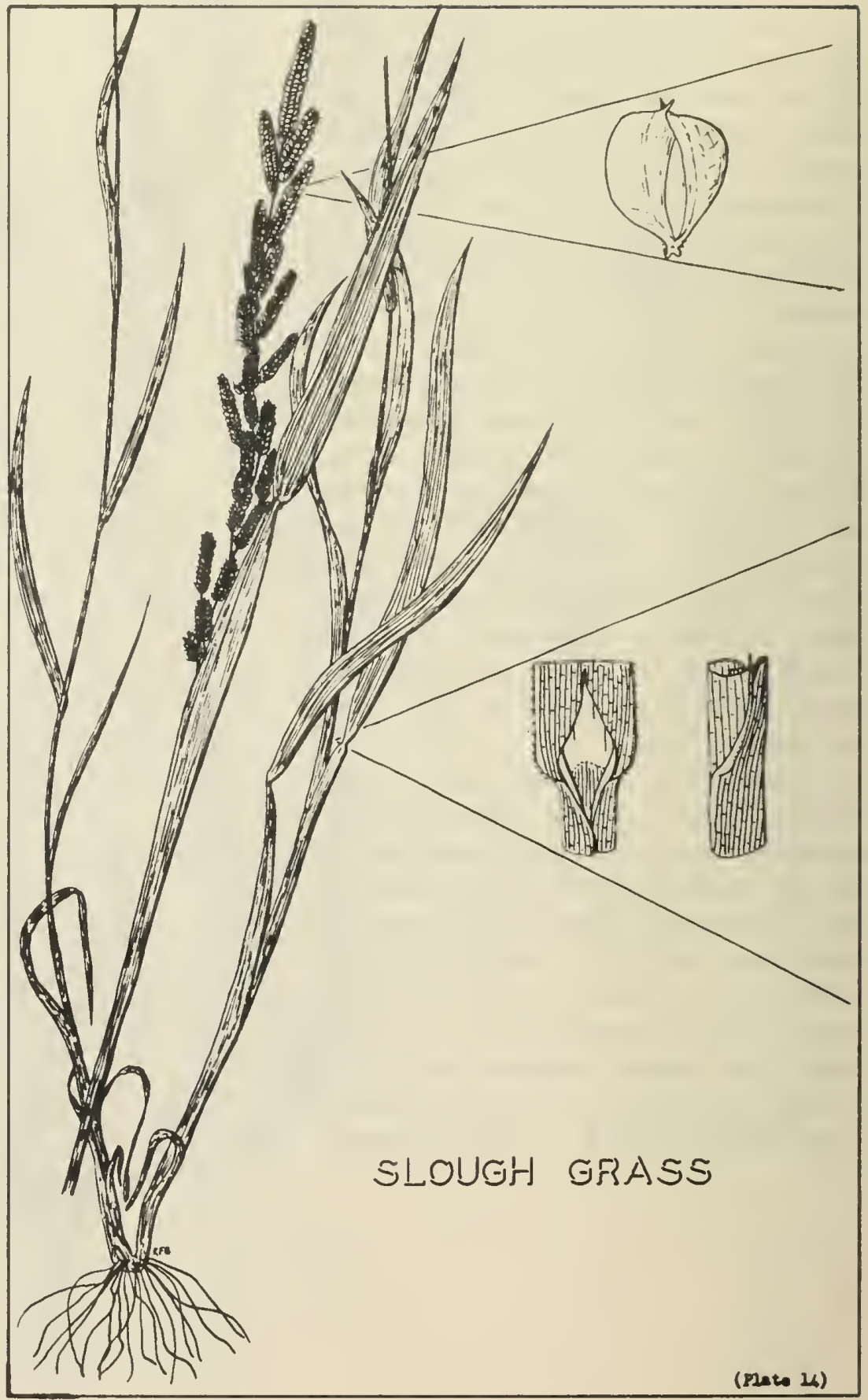




\section{BLUE GRAMA}

Bouteloua gracilis (H.B.K.) Lag.

Grama grasses are southern species. Only two extend into Canada-blue grama, which is very common throughout the prairie provinces, and side-oat grama, $B$. cutipendula (Michx.) Torr., which occurs sparsely in the Souris River basin. The name "grama" is a literal translation of the Spanish for "grass".

Blue grama is the most abundant grass in the short grass prairie. Its range extends across North America and southward through Mexico into South America. It becomes progressively sparser northward, but is quite common as far north as the tree line across Alberta and Saskatchewan. It starts growth late in the season, about May 5 in southwestern Saskatchewan and nearly a fortnight later at its northern limit of growth.

Blue grama produces a dense mat of short leaves which grow from short underground tillers as well as a crown. The pith-filled stalks are up to 16 inches tall and carry usually two dark brown, sickleshaped spikes with all the flowers clustered along the upper sides. It requires about 75 days to mature seed. It produces a mass of surface roots which extend down about 16 inches, while a few secondary roots feed down to about 40 inches.

Under the best growth conditions of short-grass prairie, an average stand of blue grama grass will yield only from 100 to 125 pounds per acre per year, which will be about 35 to 45 per cent of the totul forage production. During midsummer it does not appear to be particularly palatable, but is readily eaten during the autumn and early

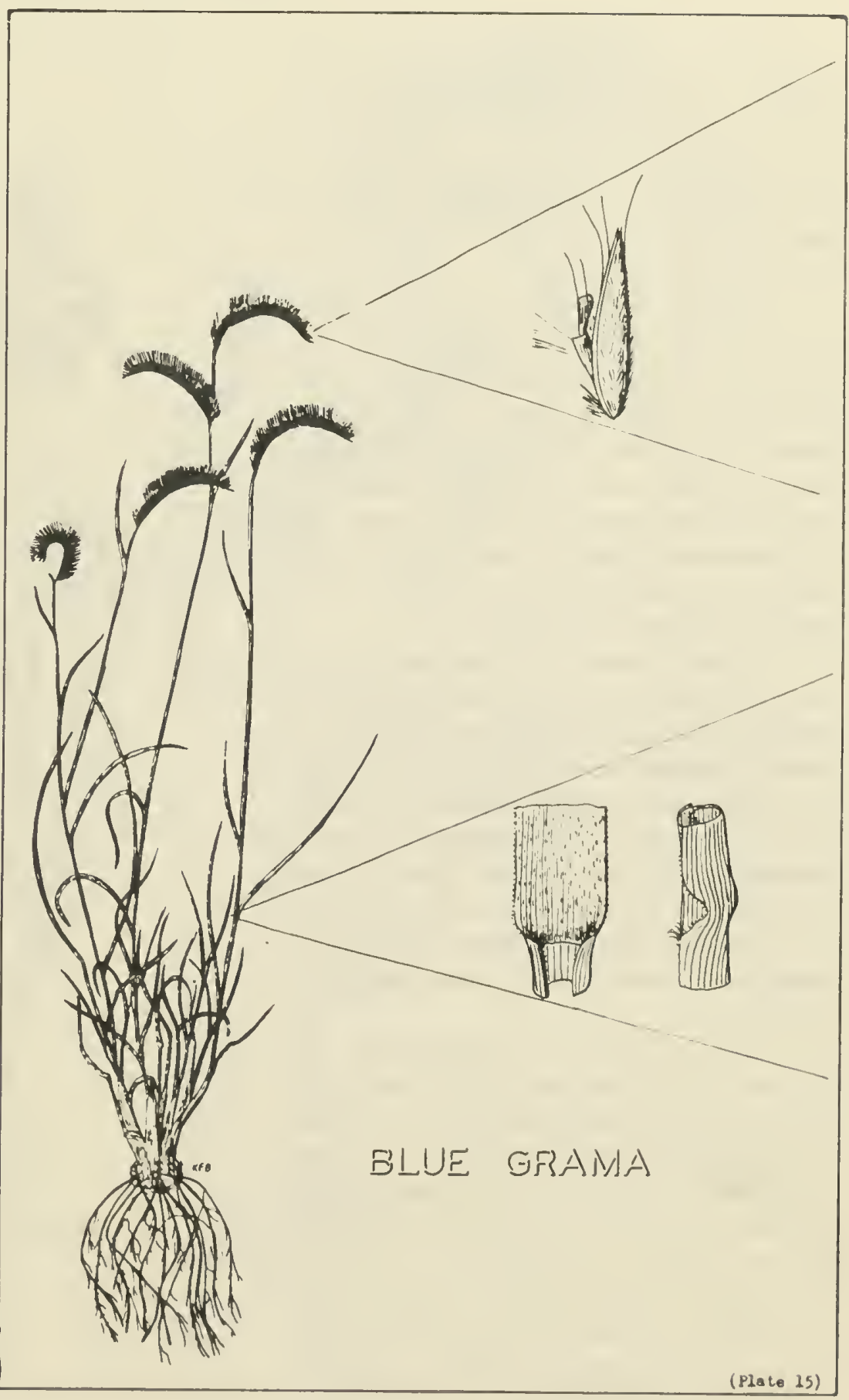
winter. It is high in digestibility and it cures on the stem. It recovers rapidly from drought and is quite resistant to grazing and trampling. Chemical analyses

indicate a well-balanced nutrient content, with protein high during the spring but dropping to about a 5 per cent level when cured. 


\section{FRINGED BROME}

Bromus ciliatus (Hook.) Shear.

Brome grasses are temperate zone grasses. Their name is derived from the Greek word meaning "food". They have a common character in that the edges of the leaf sheath are grown together to form a tube. Nearly forty species are natives of North America.

Fringed brome is a native whose range extends throughout Southern Canada and Northern United States. It possesses characters similar to several native brome grasses which are difficult to distinguish from each other and which have closely related nutritive values. Fringed brome and its associates grow in moist sites at the perimeter of the Prairie Area and at elevated sites within the region.

Fringed brome is a perennial bunch grass as are most of the native species. Its deep and extensive, but not dense, root system supports 3- to 4-foot leafy stems. The panicle is open and composed of many seeds, whose husks are covered in part or completely with short hairs. Fringed brome itself has no awns on its seeds, but some of the closely related species possess this character. Growth usually commences about mid-May.

Fringed brome is palatable to all classes of livestock from date of emergence until maturity. Sheep eat the ripe seeds with relish, while cattle and game will strip the dry leaves from the coarse stalk. Brome grasses as a group do not cure on the stem, but all produce excellent hay when cut while green and palatable. Chemical analyses show fringed brome to have a May and early June protein content of 20 per cent or more, which drops to 9 or 10 per cent by early July and as low as 3 per cent by October. Digestible carbohydrate contents increase rapidly

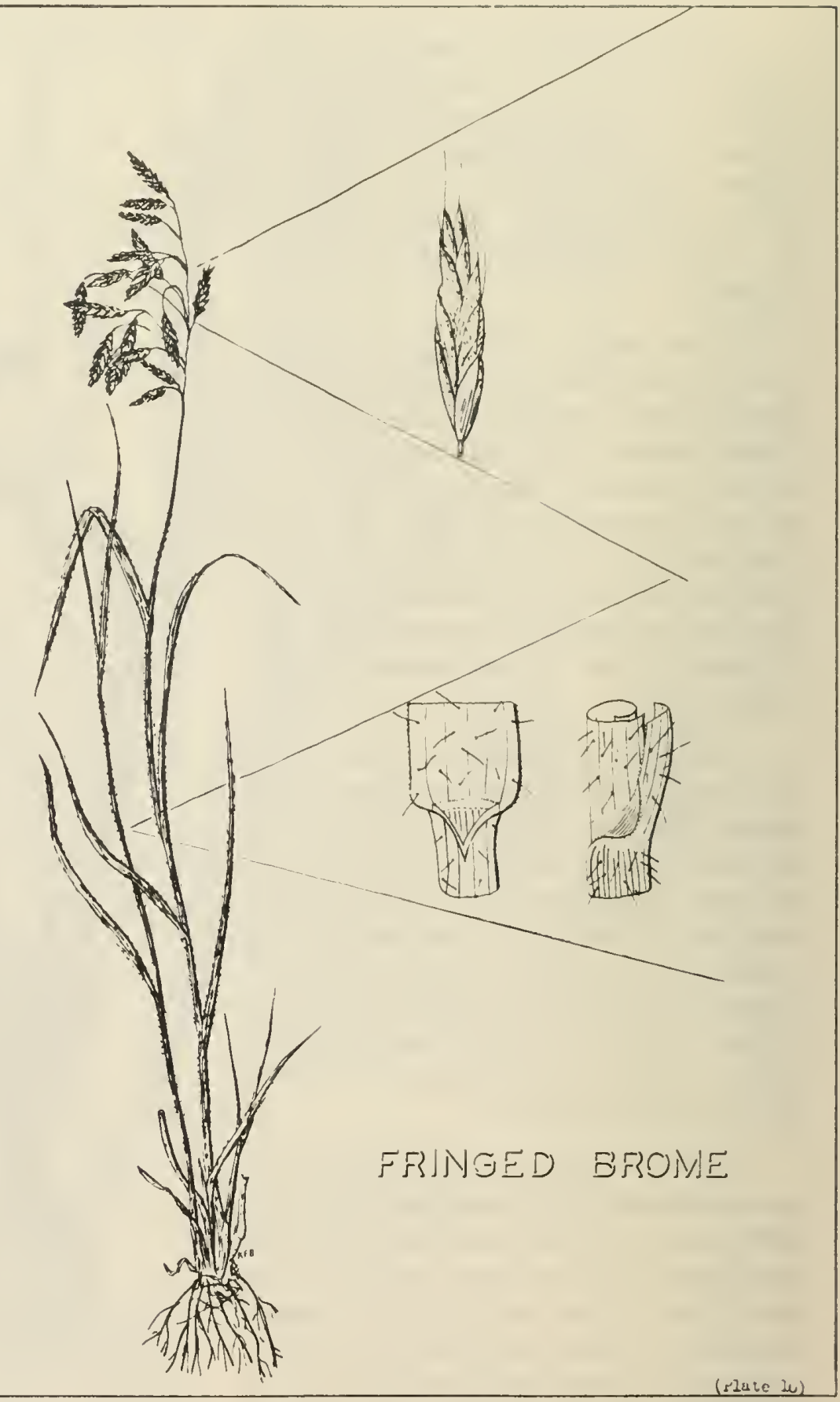

until early August but decline as the plant dries and the leaves fall off. 
Bromus inermis Leyss.

Awnless brome, smooth brome, common brome, or field brome is a perennial pasture and hay grass imported from Europe. Its home is either in the Russian Steppes or the Hungarian Plains, where it had been cultivated as a forage crop for many years prior to its introduction in North America. It adapted itself quickly and spread through the North-central United States and Western Canada. Today it is one of the best cultivated grasses forthe Dark Brown and Black soil zones of the Prairie Area.

Awnless brome has creeping underground stems or rootstocks from which the 2-to 4-foot leafy stems arise. It root system penetrates to a depth of four or more feet, but only in the first foot does a dense mass of roots develop. Both basal and stem leaves are broad, long, and tender; the sheath forms a tube. The panicle type head produces a heavy seed crop, 600 to 700 pounds per acre being not uncommon. Individual seeds are enclosed in brownish husks which may have a short awn up to $1 / 8$ inch in length.

Awnless brome is very palatable to all classes of livestock from emergence to the heading stage, after which only the basal and stem leaves and the seeds will be eaten. As the stem develops, a process known as lignification goes forward rapidly making the stem harsh, brittle, and undigestible. Growth will commence early in May, and this forage may have a protein content of from 20 to 22 per cent which drops to 4 or 6 per cent by the end of September. As the protein content drops, the the fiber increases from 18 to 35 per cent, while available carbohydrates will increase slightly from about 45 to 50 per cent. Digestibility will drop

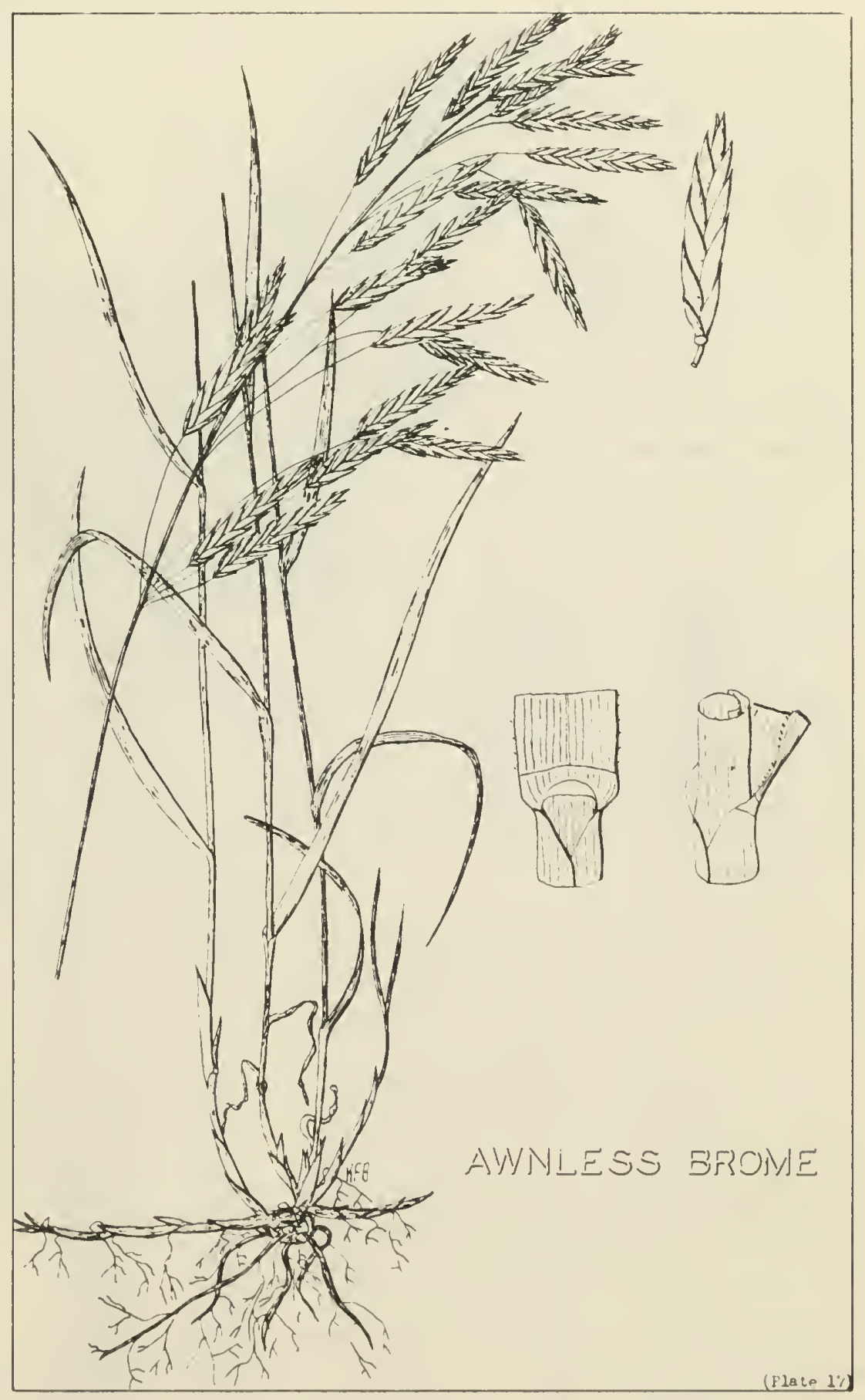

from about 60 per cent in early stages of growth to 40 per cent or less at maturity. 


\section{DOWNY BROME}

Bromus tectorum L.

Downy brome or cheat grass is an annual. It was introduced from Europe and has spread over range, pasture, and forest through the Western United States and southern British Columbia. Its only large stand in the Prairie Area is south of Lethbridge, Alberta, although small stands or even single plants can be found throughout the Foothills and into Western Saskatchewan. The species name "tectorum" is derived fron the Latin word roof, as this species grew on the thatched roofs of buildings in its native land.

Downy brome has a shallow, dense root system. From its crown it produces one to several seed stalks which are crowned with a nodding panicle. Long awns extend from the seed and catch in the fleece of sheep or hair of animals, and this assists it to spread. It starts growth as soon as the snow disappears in the spring and makes a rapid development to mature its seed and die within sixty days. Leaves are few and hairy.

Downy brome is essentially a range weed. It is palatable for from four to six weeks during April and May, but after that period it is not eaten and its dry stems create a fire hazard. Fortunately, it is not a strong competitor of desirable perennial grasses, as it invades only those sites where overgrazing and other land mismanagement practices have reduced or destroyed the natural cover. Its stands can be destroyed by cultivation and reseeding to the recommended forage crop for the district; a mixture of crested wheat grass and alfalfahas been effective in controlling the pest wherever crested wheat grass

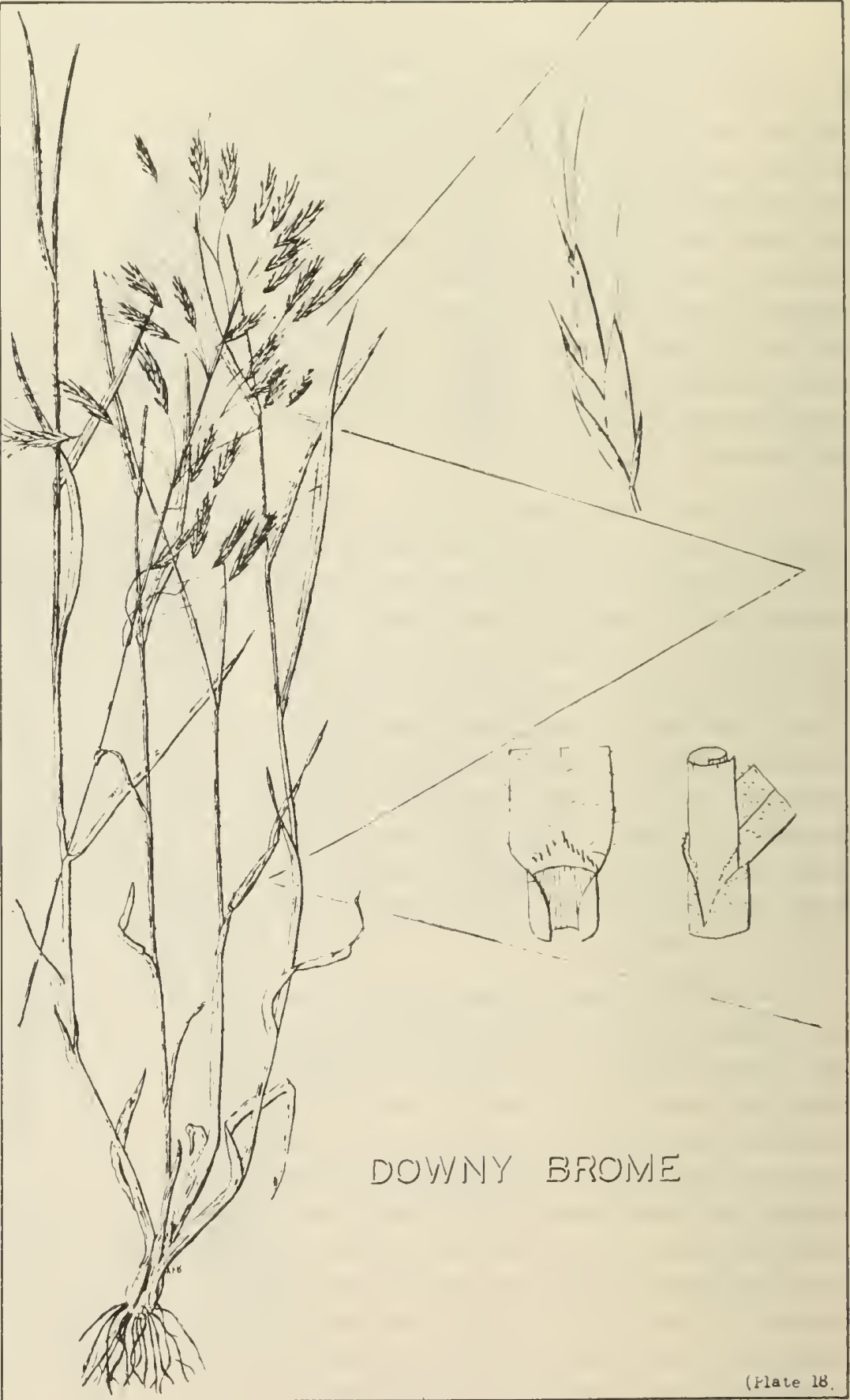
grows strongly. 


\section{MARSH REED GRASS}

Calamagrostis canadensis (Michx.) Beauv.

Reed grasses are distributed throughthe cool and temperate regions of the world. They are found growing in marshes, in the understory of forests and in dry upland sites. Few are ever dominant over large areas, but instead are sub-dominants that fill in the cover.

Marsh reed grass is the most widespread and common of the several species, extending southward from the Arctic Circle to the Southern States. It is a moistureloving plant and grows in marshes, along streams, and moist shaded draws. Occasionally nearly pure stands occur in shallow sloughs in the northern portion of the Prairie Area.

The creeping rootstocks of marsh reed grass give rise to many coarse stems which may grow to a height of 5 feet. There is considerable basal leafage and the stems produce rough lax leaves that may be one or more feet in length. The nodding seed head is often 12 inches long, with the upright branches staying close to the central column. Seeds are numerous and small, less than $1 / 4$ inch in length, and are surrounded by a dense ring of hairs that arise from the base.

Palatability of marsh reed grass is not high at any season, although the leafage may be grazed in the spring. It has been observed that palatability of this grass varies from district to district, and thus conflicting reports of its grazing characters have been published. Cut early in July, it is considered to be good hay. Excessive tramping reduces stands.

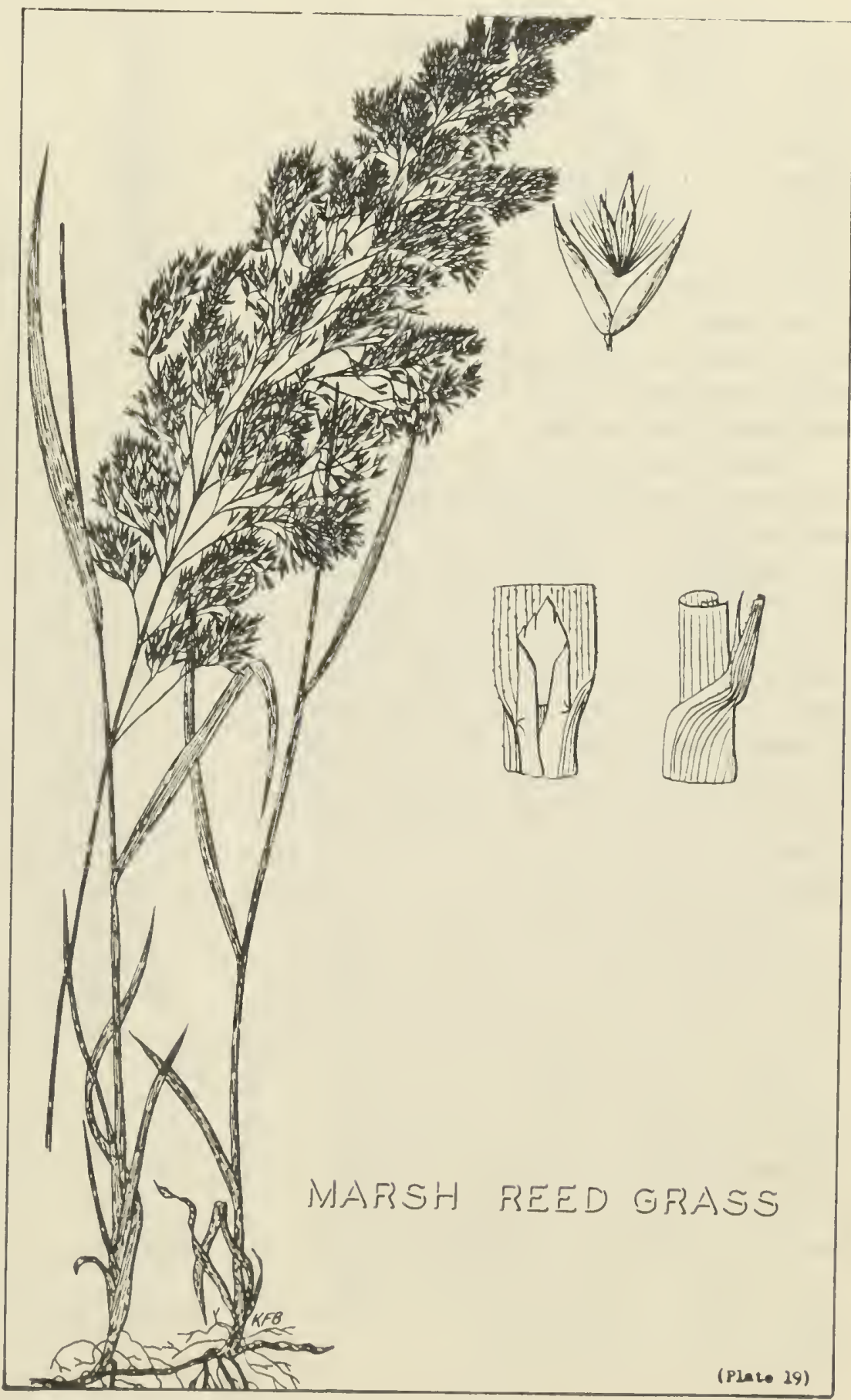


Northern reed grass has a distribution similar to marsh reed grass, but may be found at higher elevations in the Rocky Mountains. Its habitat includes springs, marshes, and meadows which have a fairly deep organic layer, and where the water table will be close to the surface throughout the summer. It does not grow in heavy or extensive stands, rather individual plants consisting of from one to six stems and the basal leafage will be separated by other grasses and sedges.

Northern reed grass has stout creeping rootstocks. It produces a small amount of basal leafage, and firm rough stem leaves. Many leafy stems arise from the creeping root, but relatively few will develop seed heads. The seed head may be from 6 to 8 inches long, with branches clinging to the central column of the stem and is readily recognized because there are numerous breaks which destroy its symmetry. The seed is less than $1 / 4$ inch in length and is surrounded by numerous white hairs that extend most of its length.

Northern reed grass leafage is relatively palatable, but the stem is seldom eaten. Watching cattle and horses grazing over a marsh or wet meadow, one will see the stems standing upright with the livestock grazing around the base of the plant. Chemical analyses indicate a high protein content during the spring, but by mid-August this will be down to about 7 per cent. Phosphorus contents are fairly high throughout the season, but drop slowly to about 12 per cent by mid-September. It is eaten readily in mixed meadow hay.

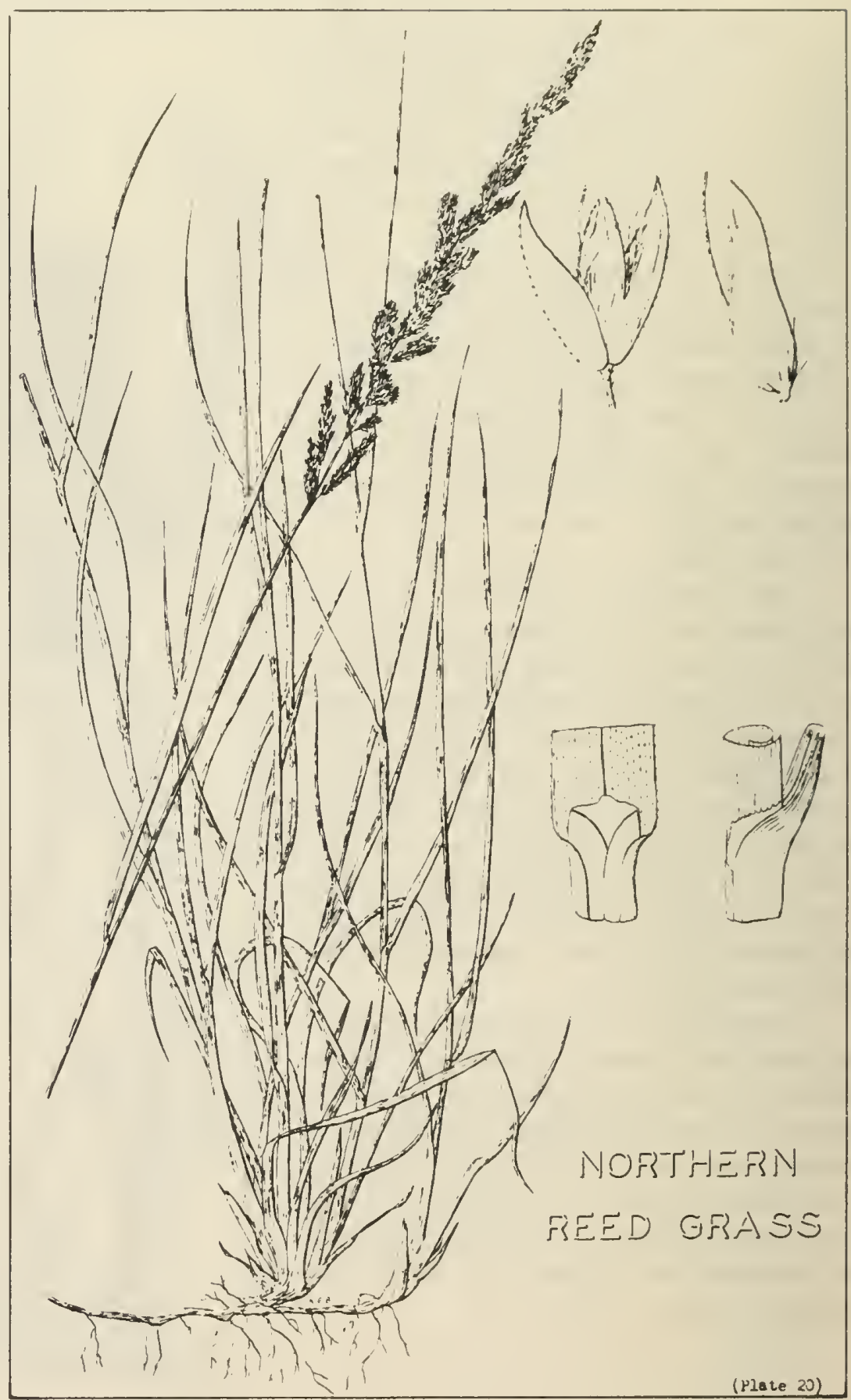




\section{Calamagrostis montanensis Scribn.}

Plains reed grass has its center of distribution in southern Alberta, and extends sparsely to the center of Saskatchewan and Alberta. It is found also throughout Montana and as far south as Utah. Its habitat includes dry prairie and benchlands, and areas where bluejoint, thread-and-needle, and hoary sage-bush abound.

Plains reed grass has slender creeping rootstocks which send up single leaves or stems at intervals. There is very little basal leafage and seldom more than two leaves on the stem, both of which cling closely. Superficially and prior to flowering, plains reed grass resembles bluejoint, but the leaves of the latter which grow at a 45 degree angle to the stem distinguish these two. The stem is erect and harsh, and seldom over 16 inches in height including the 3-or 4-inch flower head. During its flowering and seed setting stages, plains reed grass resembles June grass, but the ring of white hairs surrounding the seed hull is a character of plains reed grass which identifies it from similar appearing species.

In its younger stages of growth, plains reed grass may be eaten fairly readily, but it loses its palatability by the boot stage. It seldom forms pure stands, only one is known to the writers, and that is only a few yards square. Rather, it grows as a single stem amongst the other upland species. Chemical analyses indicate that the protein and phosphorus contents are lower than those of the associated short grass prairie species, and that crude fiber is somewhat higher.

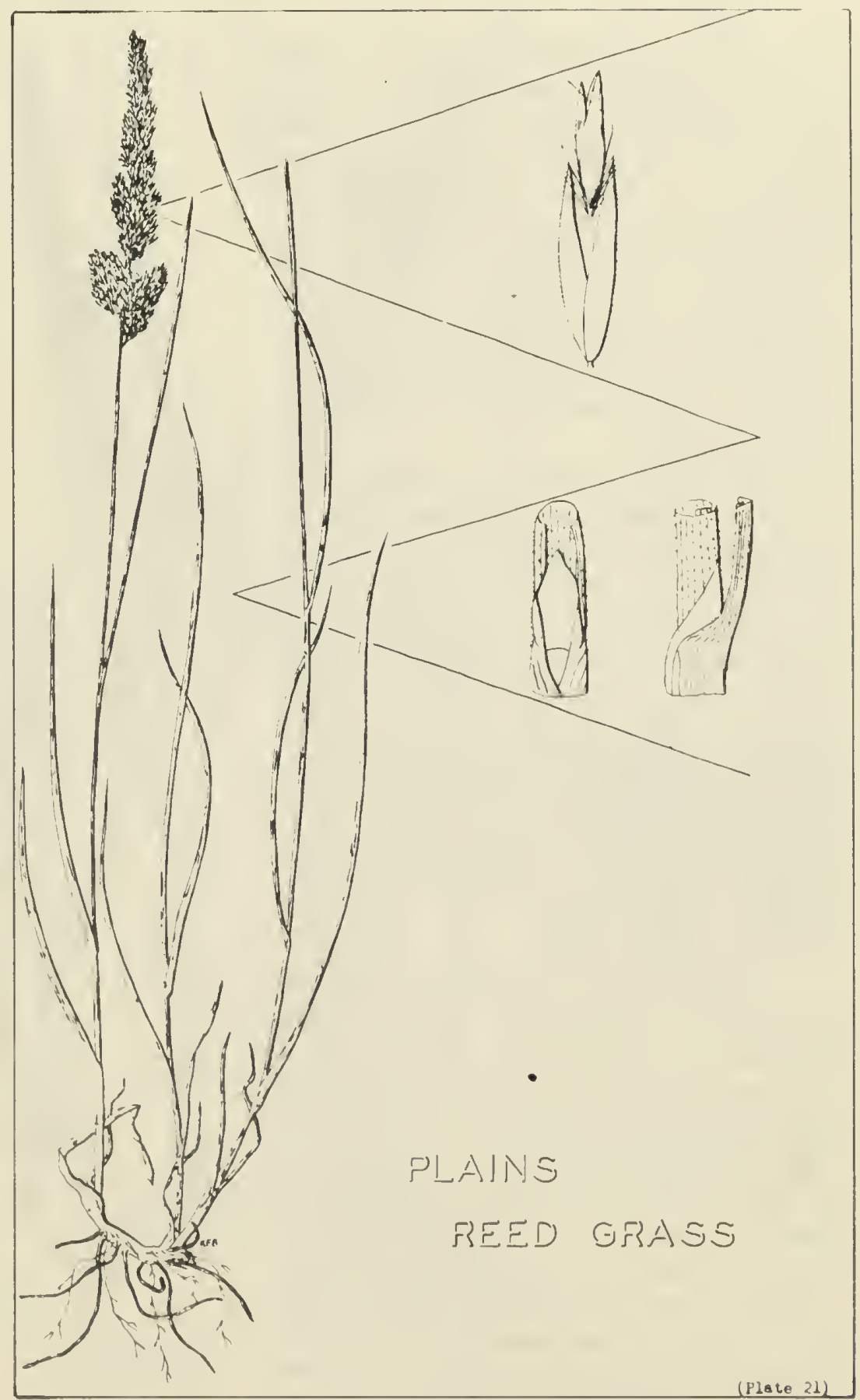


Pine grass grows in fairly dense stands in open pine, aspen, and fir woods, and in sparser stands under dense pine forests. Its range includes the four western provinces in Canada, and southward to Colorado and California. It grows from sea level to the top of the timber line, but prefers open forest sites at intermediate levels. It is common in the Cypress Hills, Rocky Mountains, and central British Columbia, and occasionally in the Northern Boreal Forests.

Pine grass grows vigorously from creeping rootstocks. Numerous tufts of leaves are often sufficiently dense to form a thick carpet. The root system is tough and very resistant to tramping, grazing, and water erosion. Although most new growth comes from the creeping rootstocks, viable seed is produced in thick heads on 2- to 4 -foot leafy stems. The reddish color of the seed head, particularly in open sites, helps to distinguish pine grass from its associated species. In general, the seed stems are relatively few in comparison with the basal leafage.

Pine grass is none too palatable except in the spring when growth is lush and tender. Close herding will force stock to graze it, but associated nutritive and palatable plants such as vetches and asters will be grazed out without damaging the resistant pine grass. Thus, management practices have to be designed to protect associated species rather than the vigorous grass. Chemical analyses reveal a relatively low protein content at all seasons; even in the early leaf stage the protein content will be less than 12 per cent, while by October or November there may be no more than 2 per cent protein in the plant. Fiber is high and fat, phosphorus, and digestible carbohydrates are lower

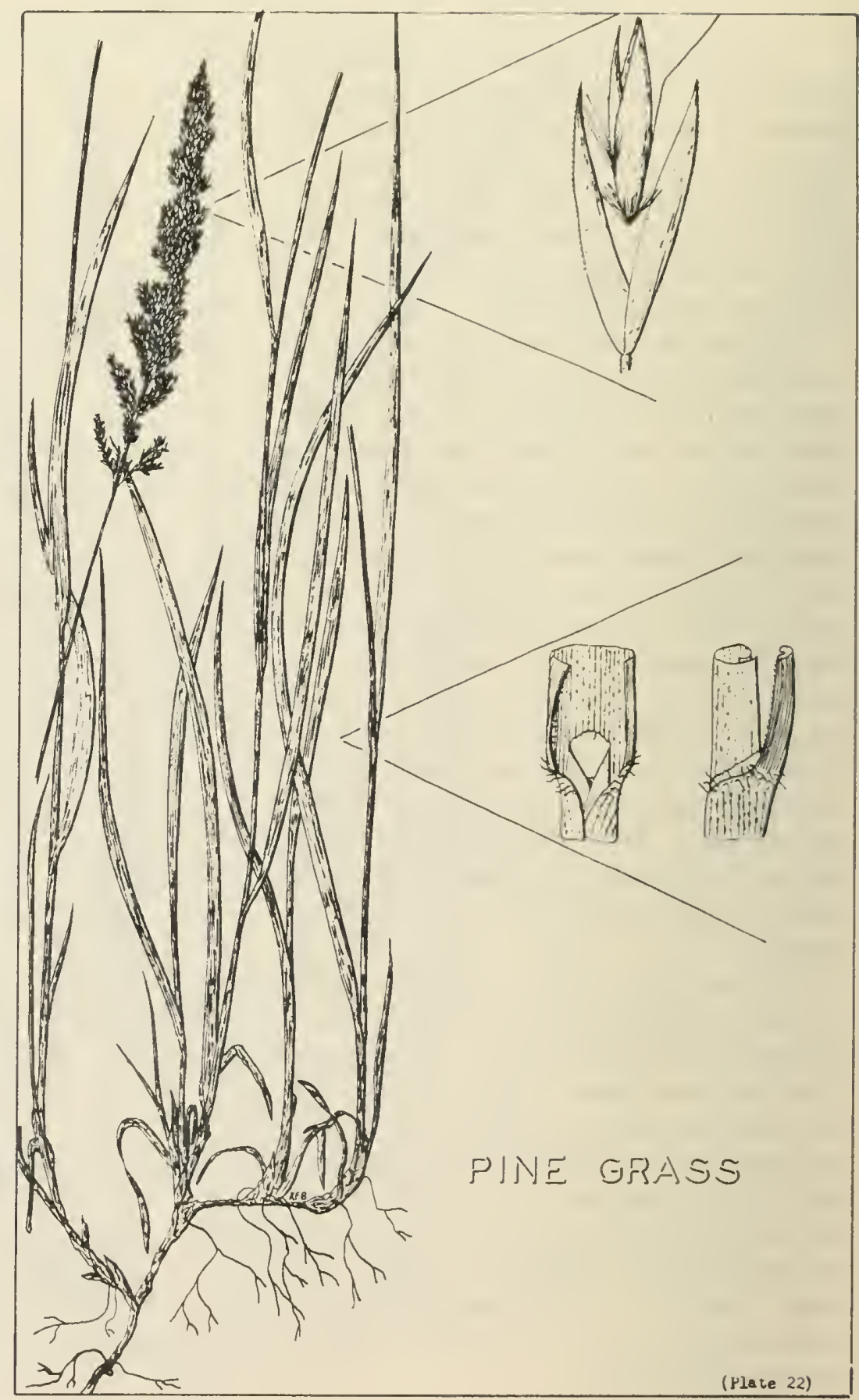

than in good range grasses. However, its wide distribution and rapid growth class it as an important range forage in areas where pine trees dominate the vegetation. 


\section{SAND GRASS}

Calamovilfa longifolia (Hook.) Scribn.

Sand grass is the only Canadian representative of the genus Calamovilfa. It grows on sandy prairie and sand dunes, along lake shores and in open forests. Its range spreads from the Rocky Mountains east to the Lake Superior region and southward to New Mexico and Kansas.

Sand grass has strong, scaly, creeping rootstocks. These send down a mass of feeding roots to a depth of about 5 feet, although most of them are found within 18 inches of the surface. The surface roots are dense and wiry, and well adapted to keep the sandy soil from blowing. Considerable harsh basal leafage surrounds the coarse leafy stems which may be up to 6 feet tall. Each stem ends in a feathery panícle which may be from 6 to 18 inches in length. The seeds are enclosed in a hull whose base is surrounded with white hairs. Leaf sheaths of previous year's growth surround the base of the stem and enlarge that section of the plant.

Sand grass is palatable during its first month of growth in the spring and after it cures on the stem in the autumn. At both periods, leafage is readily eaten, and during the autumn the livestock seek the plump and nutritious seeds. Stems are rerely eaten if other food is available. Despite its heavy root development, this species is susceptible to trampling and will disappear from sites where livestock congregate. Because sand grass is a valuable soil-binding plant on land which erode easily, care should be taken to maintain all existing stands. It is considered good winter pasture. Percentage protein contents drop from about 16 per cent during May to about 4 per cent in November. Crude fiber content does not change much during the season, but the available carbohydrates increase from about

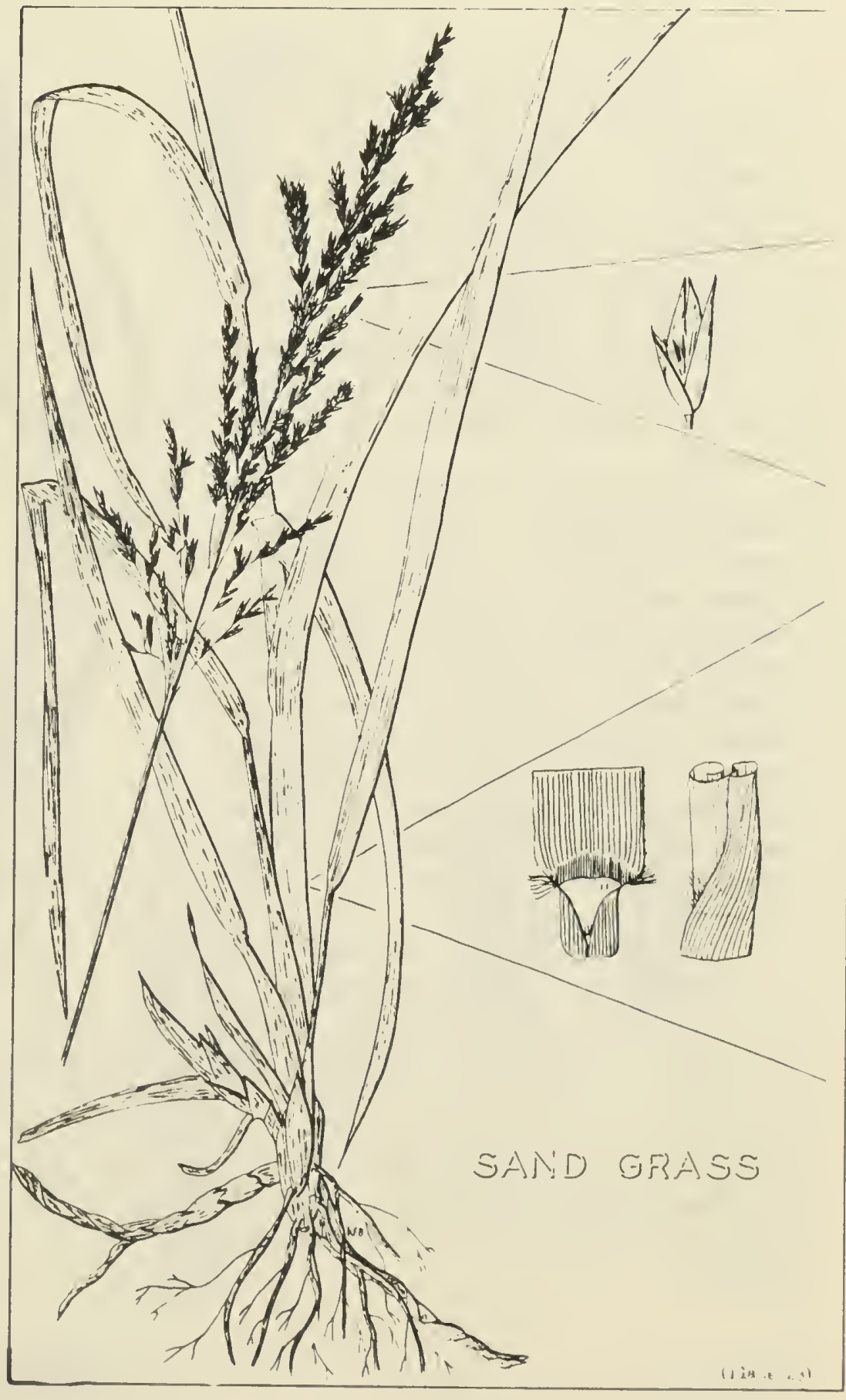

45 to 55 per cent from May to October. Despite the sandy habitat of sand grass, it does not have a high ash content. 


\section{ORCHARD GRASS OR COCKSFOOT}

\section{Dactylis glomerata L.}

Orchard grass is a native of Europe where it is known as cocksfoot. It has been cultivated for many years and is now recognized as one of the best pasture grasses in countries with moist temperate climates. It was first cultivated in North America about 1760 , and has since spread throughout the continent. It is a useful cultivated pasture grass in Eastern Canada, and has shown promise of being a desirable crop for irrigated pasture in Western Canada.

Orchard grass is a bunch grass which forms large tussocks unless it is kept grazed down. It has a dense, deep root system, and produces long, folded, shiny, dark green leaves. The 3-to 5-foot stems are leafy, and are topped with a 4-to 10-inch flower head. In general the panicle is closed, but opens during the short flowering period at which time it has a purplish appearance. The panicle has a distinctive appearance, the flower clusters are not continuous, that is, there are breaks in the symmetry of the panicle.

Orchard grass is nutritious and palatable. It requires from 20 to 25 inches of precipitation to produce high yields and nitrogen fertilizer to maintain high production. It grows well with alfalfa or red clover and, although more commonly used as pasture, it can be grown for hay. At present it is being tested for use as an irrigated pasture crop in southwestern Alberta.

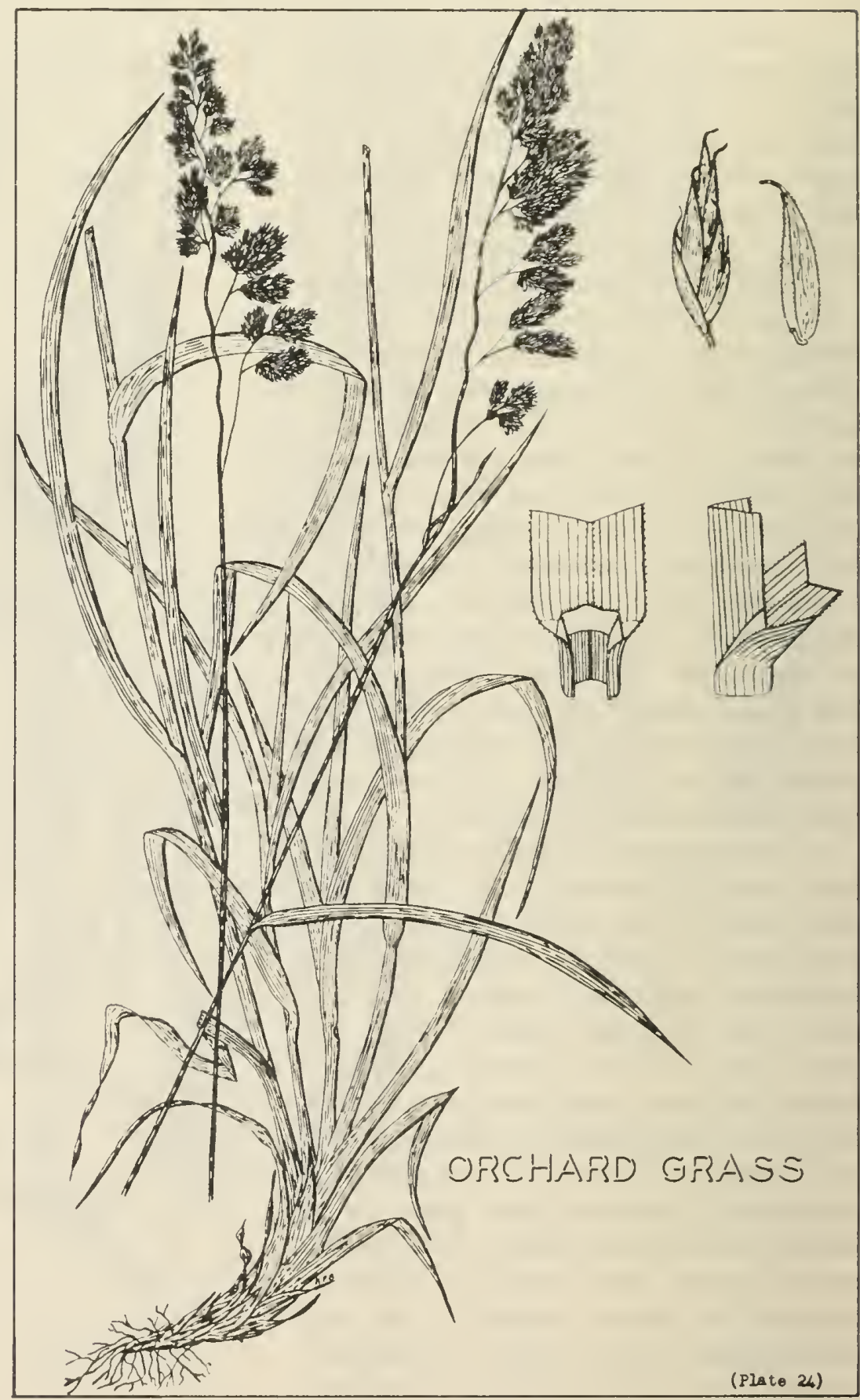




\section{Danthonia intermedia Vasey}

Oat grasses have a world-wide distribution, with members present in the rangelands of Australia, Africa, South America, and Eurasia, as well as North America. Five species occur in the Prairie Area, of which wild oat grass is the most common.

Wild, timber, or intermediate oat grass is found from Quebec to British Columbia, and as far south as California and New Mexico. It grows on meadows and upland prairie close to the tree line, and at favorable sites within the spruce and pine zones. It is common in the Foothills, Cypress Hills, and along the northern edge of the Prairie Area.

Wild oat grass grows in small clumps or on occasions may form a dense sward. $\mathrm{Plants}$ produce an abundance of basal leaves and short but numerous stems. The four to twelve purplish spikelets which form the closed panicle are crowded on one side. Flowering occurs in August and the seed crop shatters early in September. Selffertilized spikelets are hidden within the leaf sheath at the base of the stems, and after ripening the stems break off and distribute the enclosed seed.

The palatability of wild oat grass is not assured. During the spring, when it makes an early and rapid growth, reports and observations indicate that it is eaten readily. However, as soon as the head starts to form and until the end of the season its palatability appears to be of a low order. Solid stands in heavily grazed areas in the Foothills indicate that it stands grazing fairly well, but these stands appear to be the result of the disappearance of the more palatable rough fescue and awned wheat grass. Chemical analyses indicate relatively low

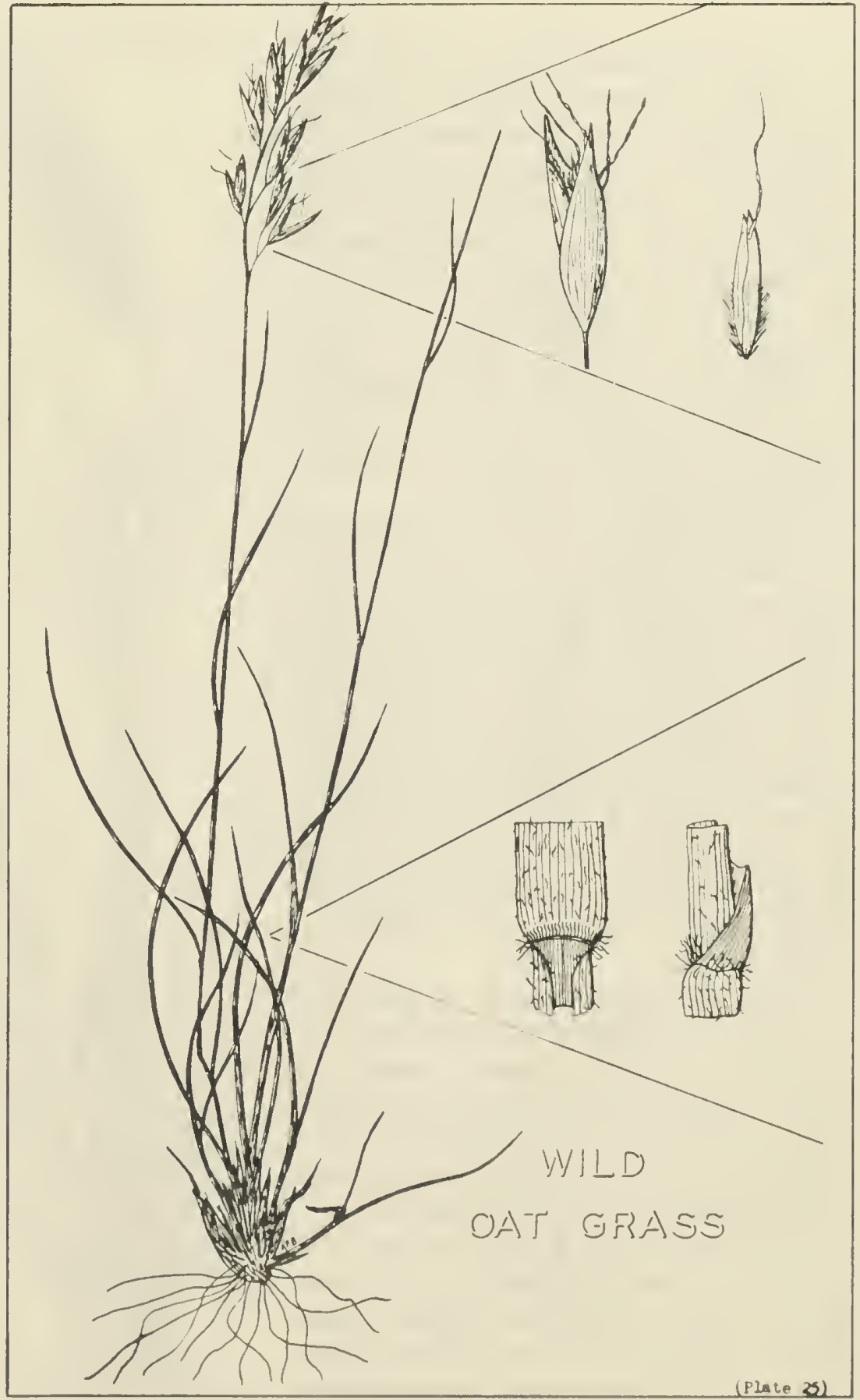

protein and phosphorus contents in all stages of growth, with a correspondingly high crude fiber content. 
Danthonia Parryi Scribn.

Parry oat grass occupies a restricted area in the southern Foothills. It has a narrow range east and west-some 30 or 40 miles-and disanpears entirely from the associations a short distance south of Rocky Mountain Ilouse in Alberta; it extends southward fron Canada as far as New Mexico. Parry oat grass and rough fescue are codominants in Foothills' pastures, with Parry oat grass forming dense communities on slopes and ridges exposed to the "Chinook" winds and rough fescue dominant in the sheltered locations.

Parry oat grass grows in tough clumps, from which the center frequently dies. Numerous overlapping, persistent, basal sheaths enlarge the base and protect young growth. Leaf blades are a light green or even yellowish-green and somewhat hairy. Year-old blades drop off before growth commences in the spring. Short, erect stems are topped with a closed panicle which carries a few large spikelets. Seeds in the exposed spikelet are seldom developed, but those enclosed in the lower sheath are usually fertile.

Very few observations are available to indicate the palatability of Parry oat grass. It is so well equipped naturally to protect itself against heavy grazing, trampling, and fire, that it persists after less resistant species disappear, although wild oat grass will outlive it in pastures containing mixed stands. Where abundant, it is considered to be an indicator of good winter pasture. Chemical analyses suggest a good nutritive balance with protein being lower during the spring than mixed prairie grasses but higher in midsummer and early autumn.

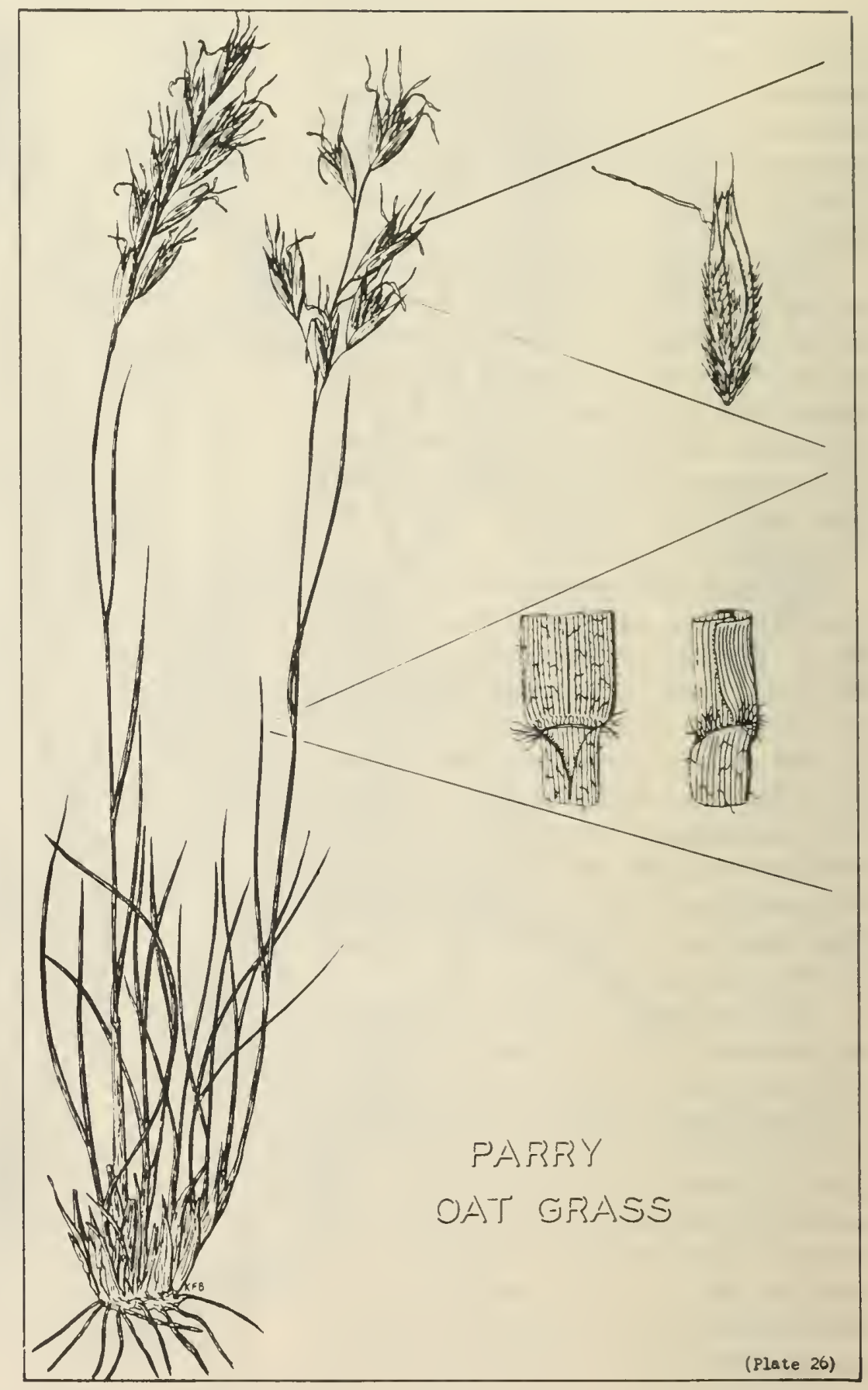




\section{TUFTED HAIR GRASS}

Deschampsia caespitosa (L.) Beauv.

Although some six different species of hair grass occur in North America, unly tufted hair grass is widespread and abundant. It occurs in the Rocky and Appalachian Mountains in the United States and Northward into all provinces of Canada and to Iceland. In the drier central portion of the Prairie Area, it grows sparsely in marshes or around shallow sloughs, while at the boundaries of the Area and in the Cypress Hills, tufted hair grass may be the most important species in all permanently moist sites, such as marshes, springs, and narrow ravines. It seldom grows under trees.

Tufted hair grass is a bunch grass, depending entirely on seed to maintain its stands. It has dense shallow roots and a mass of deep green leaves covers the crown. The leaves are folded and there is a noticeable swelling where the sheath and blade join. One to twenty straw-colored stems from 2 to 3 feet tall are produced by each plant. The head is a feathery panicle that will have several branches which grow in whorls of six or ten at points about one inch apart. There are two soeds on each spikelet. Tufted hair grass is rated as a highly palatable species that is resistant to grazing. It starts growth early in the spring and its leaves remain green throughout the summer. Very lush growth may be refused by livestock, as well as the mature leaves which are coarse and wiry. Management practices should allow seed to set in abundance because the plants are short-lived and reproduce only from seed. Chemical analyses show high protein contents of up to 20 per cent in May, which decrease to 7 per cent by August. Fiber is relatively low and phosphorus contents are well above average. Tufted

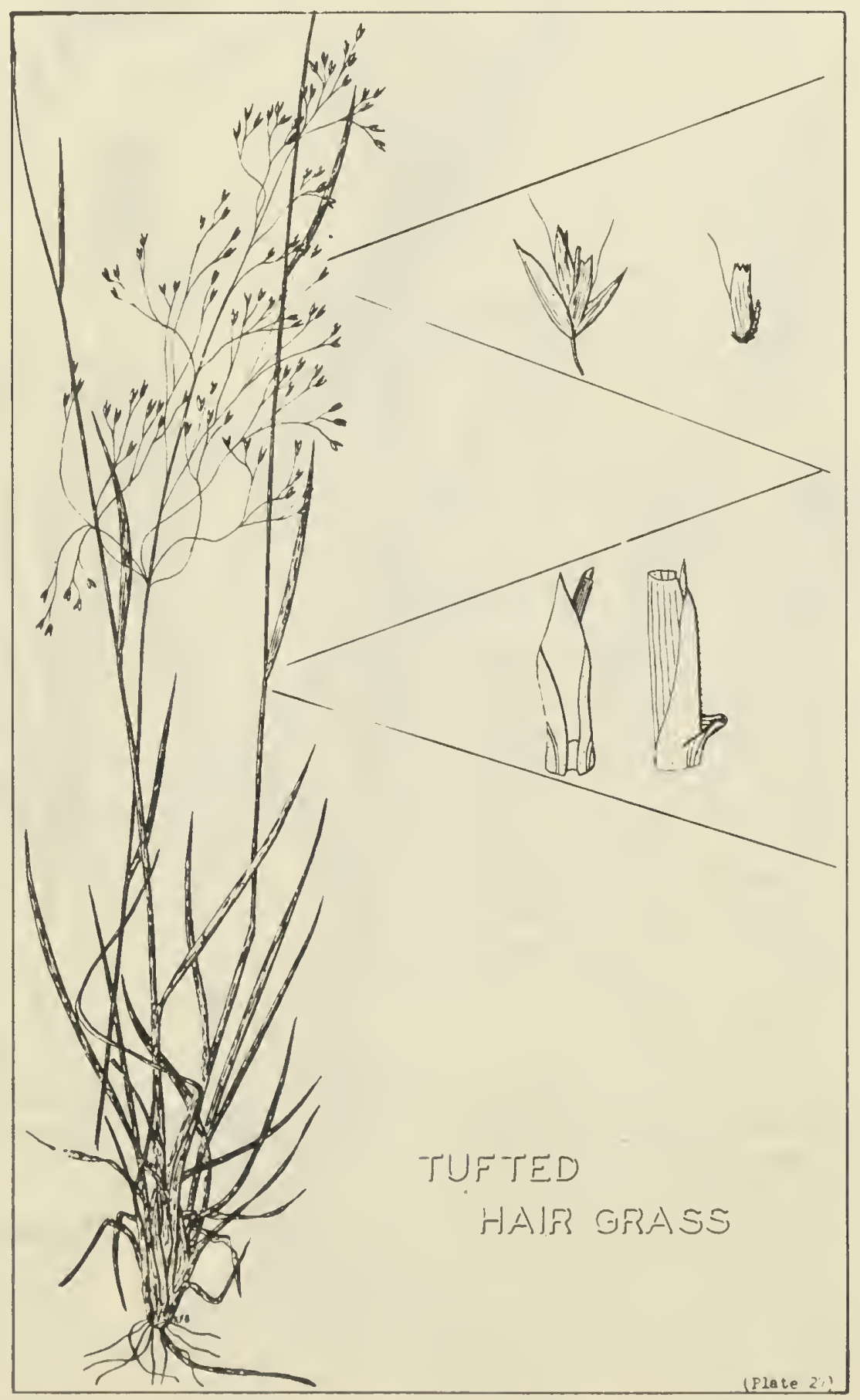

hair grass is a valuable range grass which should be preserved wherever it grows. 
Alkali grass or desert salt grass is the only species of the salt grass genus which is found in the Prairie Area. Its range extends from the Pacific Coast to the Red and Mississippi Rivers, and southward from the Northern Boreal Forest through the United States and Mexico. Its habitat includes all moderate saline or alkaline soils, particularly around sloughs, throughout flats, and occasionally on upland. Soil analyses at sites where alkali grass is abundant show that the surface layers contain from 0.3 to 0.6 per cent soluble salts, while soil samples from a 2-foot depth may contain more than 2 per cent. These concentrations are sufficient to reduce growth of all cultivated crops and most natives even under irrigation.

Alkali grass grows from scaly, yellowish, creeping rootstocks. It has a relatively dense, shallow root system, with a few deep feeding roots. There are few basal leaves, but numerous short leafy stems which may or may not end in a flower head. Male and female flower heads are on different plants, with the male flower clusters being more numerous, larger, and a deeper yellow than the female; both usually grow in the same clump.

Alkali grass will not be eaten if other forage is available because the plant is tough and wiry during all seasons of growth. If other forage is not available, then livestock will graze alkali grass readily and will make fair to good gains. The tough root system is resistant to tramping and stands are maintained even when heavily grazed. Alkali grass is an important grass to prevent and control erosion on saline soils. Chemical analyses show a well-balanced nutrient composition with protein and phosphorus

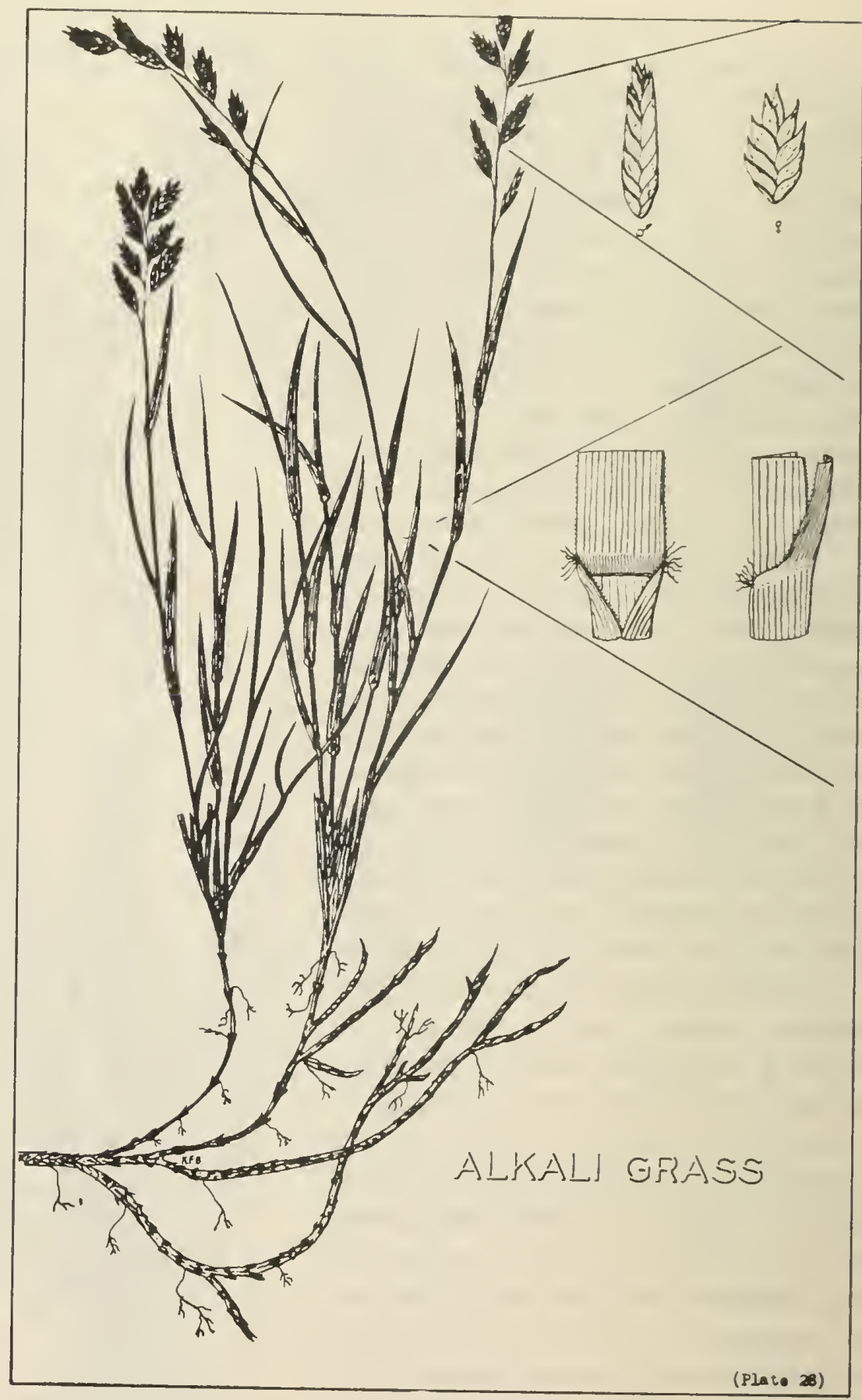

being average, crude fiber low, and available carbohydrates relatively high. 
Elynius canadensis L.

Over twenty wild rye species are natives. In general, none are very palatable to livestock, but many are useful soil binders. One introduced species, known as liussian wild rye, is becoming an important cultivated pasture grass in the Prairie Area. All rye grasses can be recognized by the two spikelets at each node in the head.

Nodding wild rye is a native species. Its range includes all of North America. In the Prairie Area it is found in sparse stands on sandy soil and along river banks, roadsides, and other disturbed ground. Attempts have been made by selection and breeding to develop strains of this grass for improved pasture and hay. The best of these is known as Mandan wild rye.

Nodding wild rye has a bunch or tussock type of growth. Deep and wide spreading roots anchor the plant firmly and provide nutrients for the yellowish-green leaves and stem. There is considerable basal leafage, and the tall stems are leafy from their base to the spike. The spike itself is about 6 inches long and nodding. The spikelets, two at each node, are rough and long awned. The plant is a heavy seed producer, but special seed treatment is necessary to remove awns before the seed can be sown through a drill.

Nodding wild rye is not very palatable, although it will be eaten in the spring. Its mature growth has been described as being "even poor bedding", although hay of fair quality is obtained when harvested in the boot stage. Although livestock will eat this hay, they do not take to it readily and their gains are seldom satisfactory. Because the plants start a late spring growth, later than most natives, very little use is made of the plant even in its most palatable state. llowever, nodding wild rye

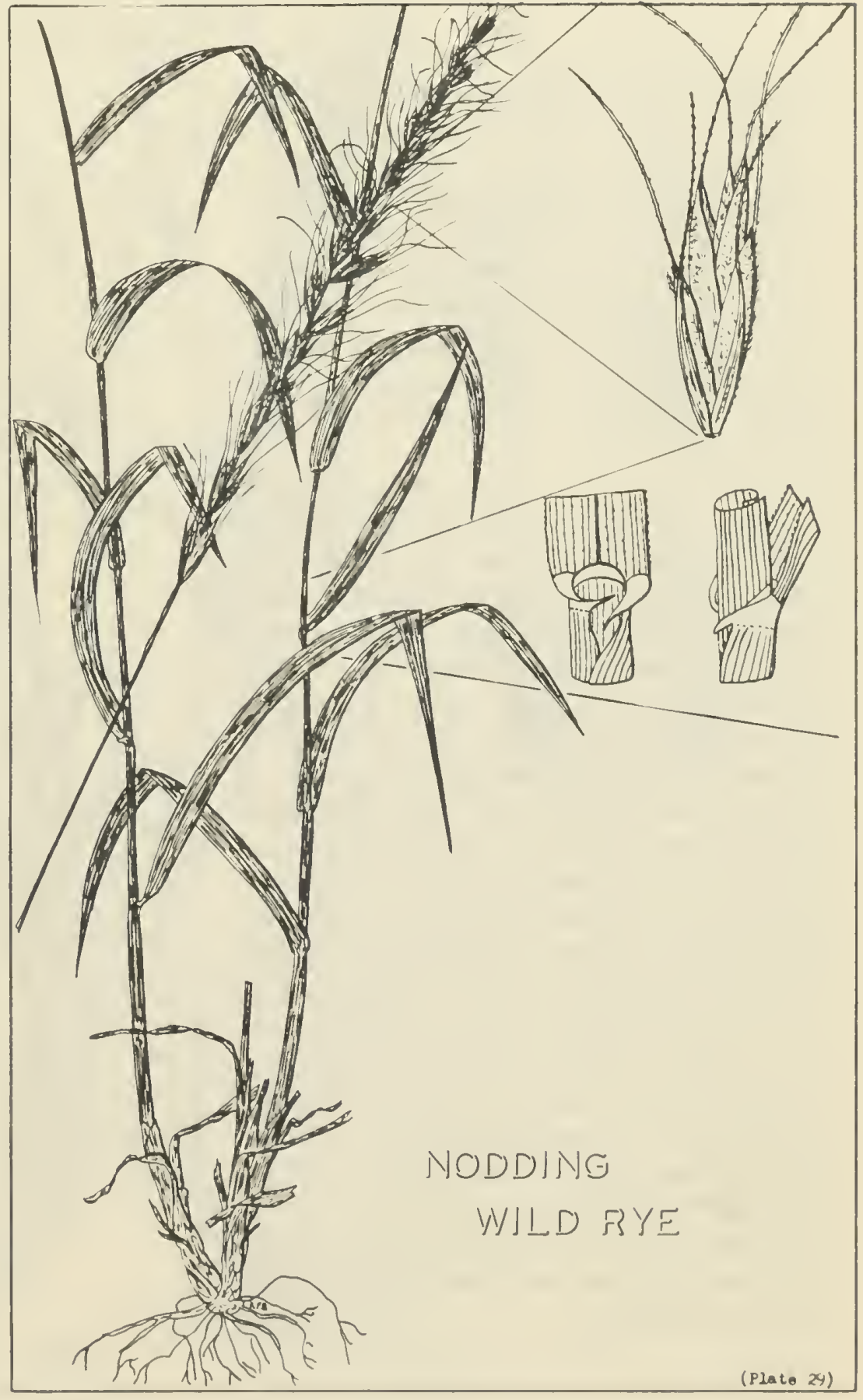

establishes itself quickly and is a useful plant to control erosion. It competes successfully with crested wheat grass. 


\section{Elymus innovatus Beal}

Hlairy wild rye grows from Alaska to the Red River in Manitoba, and southward to include the states of Montana, North and South Dakota, Idaho, and Washington It develops dense stands under open poplar and jackpine sites where the soil is sandy or gravelly. In the Prairie Area it occurs within the Parkbelt and northward, and in the Cypress Hills and throughout the lower ranges of the Rocky Mountains. It comes in quickly on all sites cleared of poplar and jack pine.

Hairy wild rye grows from slender creeping roots, as well as from the abundant seed supply. A deep and spreading root system supports the plant. There is considerable basal leafage which is light green and hairy, but the tall straw-colored stems are relatively free of leaf growth. The hairy spikes are dense, nodding, and as much as 6 inches in length. There are two spikelets at each node of the spike. These spikelets may produce from two to six flowers, each of which may develop into a seed. The entire spike is very hairy, which gives a characteristic bluish or grayish color to the head and which gives this plant its name. Hairy wild rye is not palatable and will never be eaten if other grasses are available. The coarse leaves and stems are not succulent at any times, and thehairiness of the entire plant undoubtedly discourages consumption. However, the plant fills a definite need in that it comes in quickly on denuded sites, and thus reduces wind and water erosion.

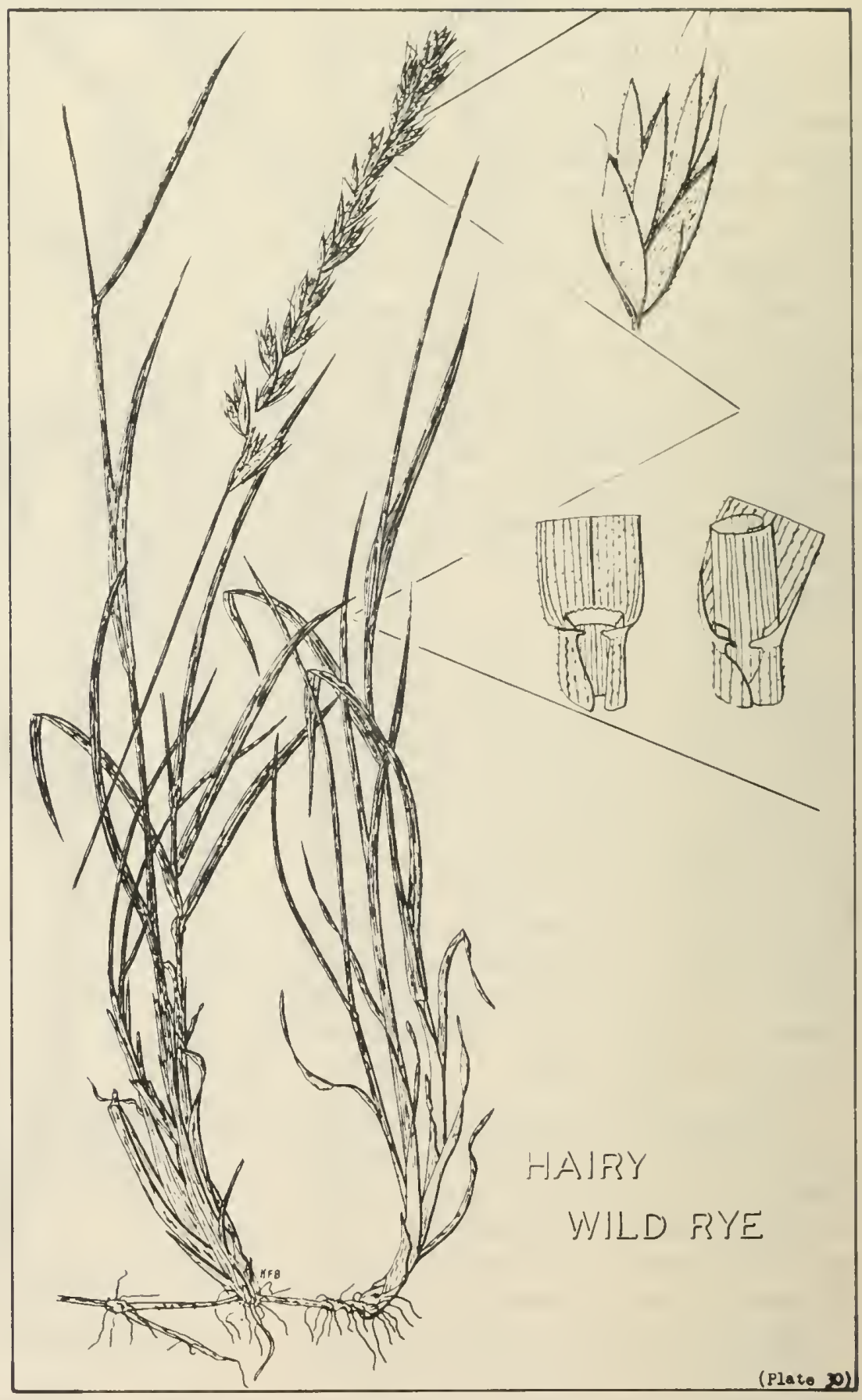




\section{RUSSIAN WILD RYE}

Elymus junceus Fisch.

Russian wild rye was introduced into the United States some forty years ago from its home in Western Siberia. Within a few years it was being tested at Experimental Stations and Universities in Western Canada. Because it is not a particularly high yielding species for either hay or seed, its better qualities of drought and cold tolerance, high protein content, and autumn palatability were overlooked when grasses were being selected for pasture in the Prairie Area of Canada. At present it is being used as a pasture crop on a few farms and new knowledge of its value and growth character should encourage its spread as a dryland pasture on loam soils.

Russian wild rye is a deep-rooted bunch grass. It produces a large number of deep green basal leaves, and a few 3- or 4-foot leafless stems which are strawcolored when mature. The seed head is a spike with overlapping spikelets. There are two spikelets at each node, and each spikelet may contain from one to four or more seeds.

Russian wild rye pasture is grazed at all seasons, but with greater relish from August to November. During this period its protein and digestible carbohydrate contents will be higher than those nutrients of other cultivated as well as of native grasses. It is essentially a pasture grass because the basal leafage develops clumps which are difficult to cut. However, it does cure into a very palatable hay which has produced excellent gains in a few feeding tests. Also, it cures on the stem as do many native species.

Russian wild rye should be seeded in wellprepared summerfallow. Seeding rates of 7 to 8 pounds per acre in 12-inch rows are recommended for pasture,

while 3 pounds per acre in 36 -inch rows are recommended for seed production. Seed supplies can be purchased from most seedhouses in Western Canada. 
Elymus virginicus L.

Virginia wild rye has a wide distribution throughout North America. In the Prairie Area it is found along streams, under poplars, and throughout moist areas generally, although it is not resistant to ponding or excessive flooding.

Virginia wild rye is a bunch grass with a few basal leaves and a large number of stems which carry long limp leaves from the base to the spike. The plant has a shallow but dense root system which fills up the soil and helps to establish stands quickly. The light green colored stems are often 3 feet tall and are smooth and shiny. The spike is erect, often partly enclosed in the upper leaf, and bristly in appearance. There are two spikelets at each node, and each spikelet will contain from two to five seeds. Awns from $1 / 2$ to $3 / 4$ inch in length extend from the tip of the shiny seed hulls.

Virginia wild rye is extremely variable in its appearance. Some forms have nearly awnless seed hulls, others have very hairy seeds, while the leaves may be either short and narrow or long and fairly wide. However, no matter the form, this grass has a low palatability rating. As with most other wild rye grasses, it has a low protein and high fiber content at all stages of growth, and a particularly low protein rating after autumn drying. It does not cure on the stem and is relatively short-lived.

Plant studies have been undertaken to select desirable strains of Virginia wild rye and to improve these strains in plant breeding programs. This work has increased yields, palatability, and stand establishment. However, in areas where it will grow, other grasses such as brome grass and timothy will outyield it and produce more palatable

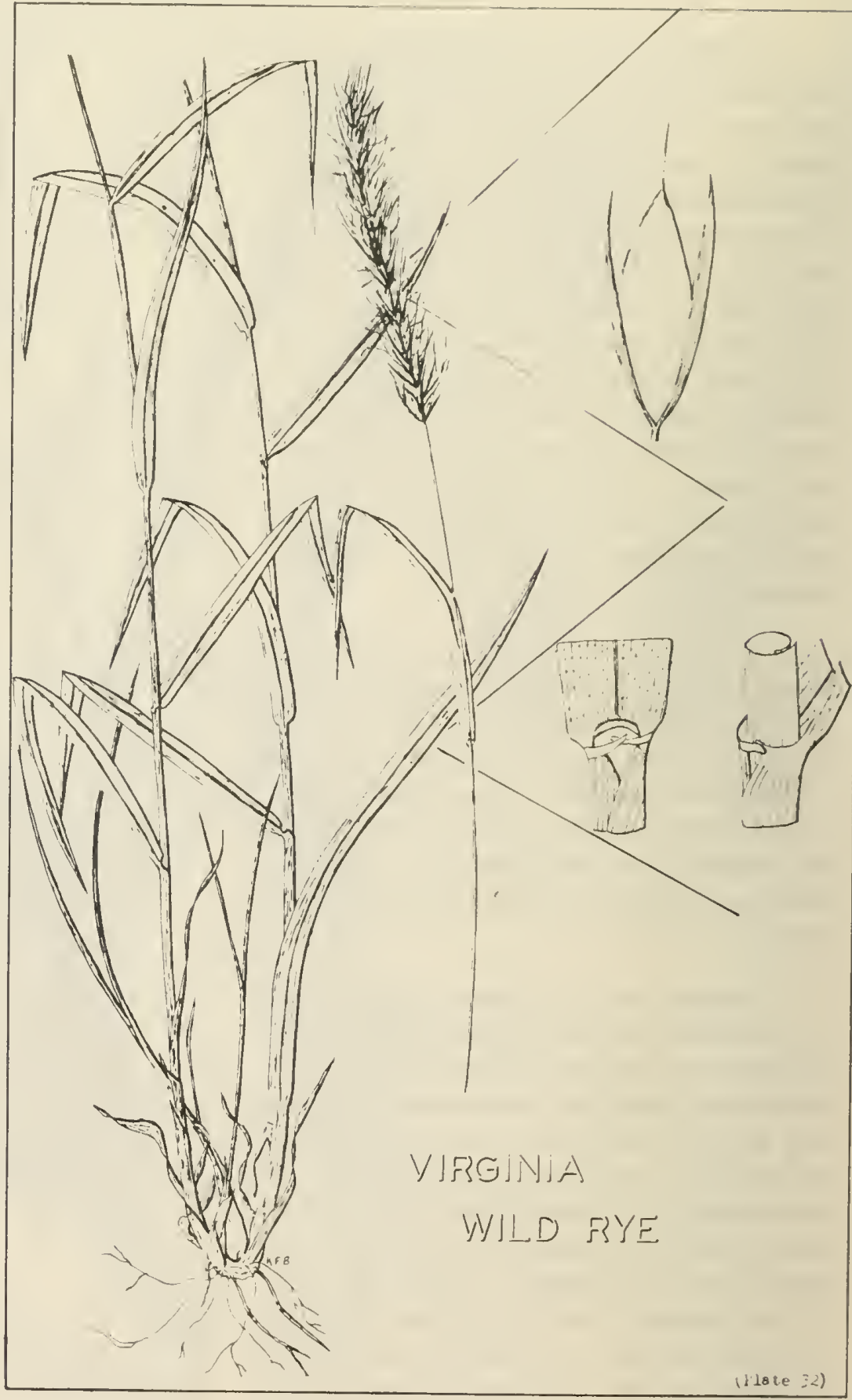

and nutritious feed. 
There are over one hundred different species of the fescue group growing in temperate regions throughout the world. A few of these have been used in cultivated pastures throughout Europe for many centuries. Two native and two introduced species are important grasses in the Prairie Area of Canada.

Tall fescue was introduced into Canada from England, but is a native of Central Europe. Since its introduction, it has been cultivated for pasture and hay for several years, and has spread from fields into waste lands in certain districts. It appears to be adapted to the moist conditions of Eastern Canada and the United States, as well as to favorable sites in the western half of North America.

Tall fescue has an open bunch habit of growth. Plants extend the ir basal area by tufts which grow from the edge of the crown. Three-to four-foot coarse leafy stems support an open nodding panicle. Seeds are numerous and short-awned.

Tall fescue has not been grown to any extent in the Prairie Area. Improved strains have been selected for marshy and wet soils in Eastern Canada and work is being conducted to determine its place elsewhere.

A closely related and very similar species - meadow fescue, Festuca elatior L. - has been tested and does well in mixtures with brome and timothy at the edge of the Prairie Area. It develops stands quickly and has some drought tolerance, but is shorter-lived and less palatable than timothy, brome, or alfalfa. It has been used to some extent in irrigated pasture mixtures in southern Alberta and Saskatchewan.

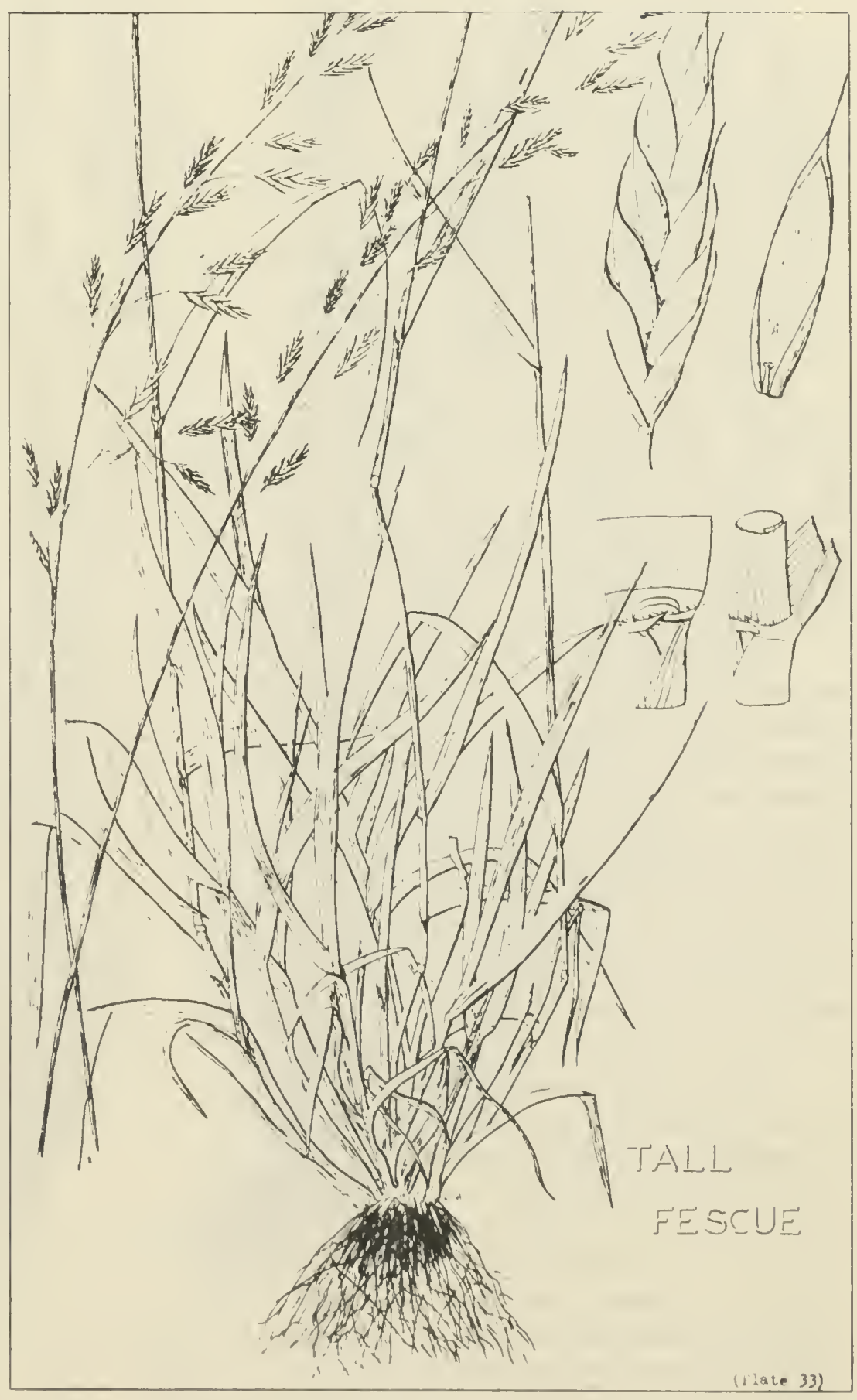




\section{BLUEBUNCH FESCUE}

\section{Festuca idahoénsis Elmer}

Bluebunch or Idaho fescue is a native species whose center of distribution is Niestern Montana. It extends northward through the Footlills in Alberta to a point north of Calgary, and eastwards along the Milk River Ridge and into the Cypress Ilills. It grows in extensive colonies in open pine and poplar forests, on exposed benchlands, in meadows, and under many other conditions at elevations between 3000 and 7000 feet.

Bluebunch fescue is deep rooted. Its dense basal leafage is fine, long, and blue colored, and spreads by tufts growing at the edge of the clumps. The few 1- to 2foot nearly leafless stems bear a 2- to 6inch closed panicle. Spikelets produce up to nine flowers, most of which will set seed. The seed hulls are strongly awned.

Bluebunch fescue is one of the most palatable forages in the association where it grows. It has average protein and phosphorus contents, which are high during the spring but decrease as summer advances. Despite its lower contents of nutrients during the fall, its cured forage is sought by livestock and eaten as readily as it was during the spring. It is resistant to grazing and tramping, but when abuse reduces its stand it is replaced by species of speargrass or the less palatable wild oat grass.

Two closely related species, sheep fescue, $F$. ovina L., and California fescue, $F$. californica Vasey, grow in the same general area. Both, however, have green leaves instead of the bluish color of bluebunch, and can be distinguished from each other by the longer awns of sheep fescue. The grazing characters of bluebunch fescue apply to these two species except that neither cure so completely and thus are less desirable

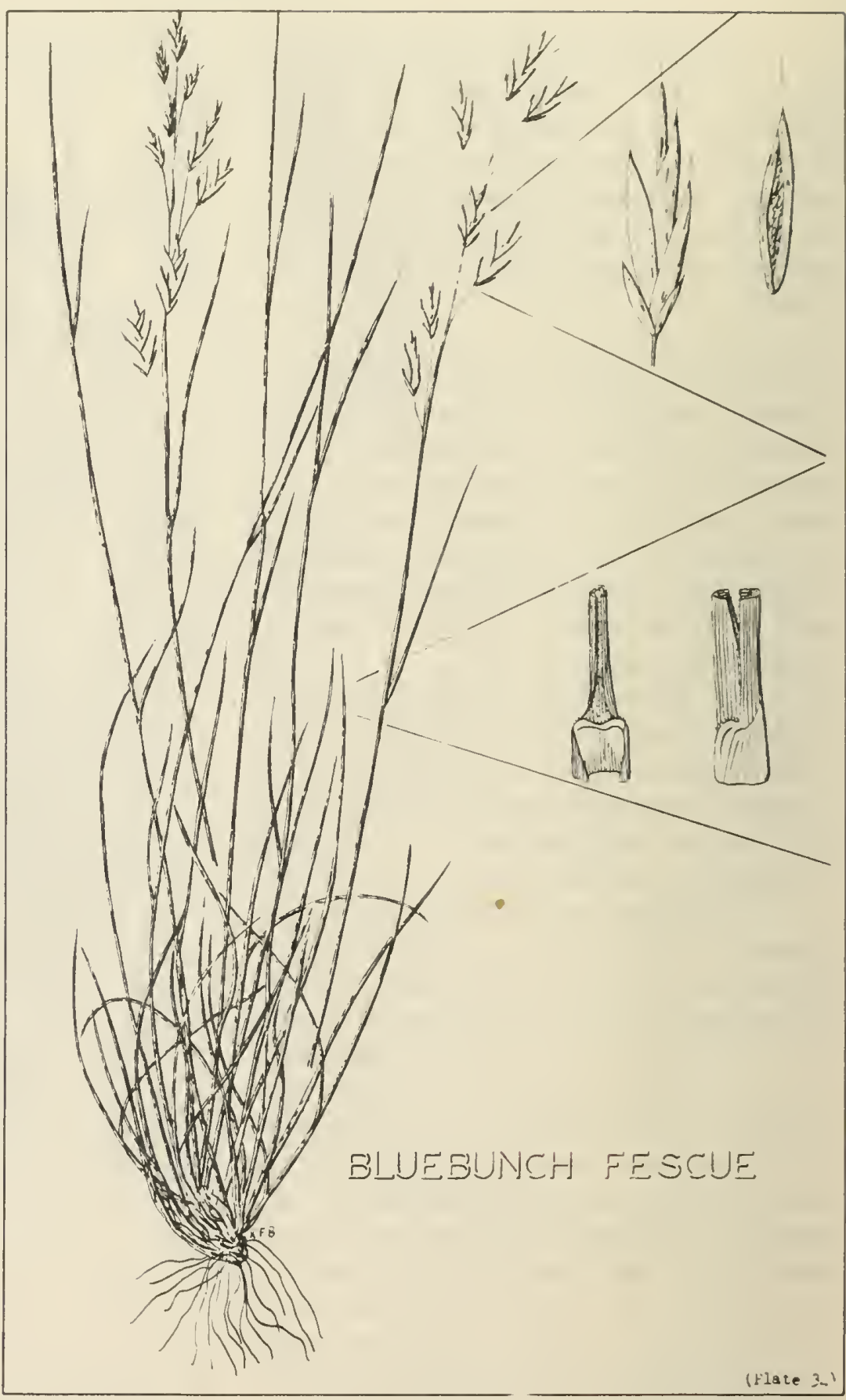

fall and winter forages. 


\section{CREEPING RED FESCUE}

Festuca rubra L.

Creeping red fescue is a temperate zone plant with a wide distribution. Forms of the species are native to North America, North Africa, Eurasia, and Iceland. In North America strains of the species are found throughout the Allegheny Mountains and Atlantic marsh areas, as well as in certain coastal ranges of the Rocky Mountain formation. It has demonstrated itself to be a very useful pasture grass at the western and eastern edges of the Prairie Area, in mixtures for irrigated pastures in southern Alberta, and to prevent erosion on irrigation ditches throughout southern Saskatchewan. It will grow farther north than any other cultivated grass.

Creeping red fescue has variable creeping habits. Some strains spread only by tufts from the central crown, while others have fairly strong underground stems. It has deep feeding roots. All leafage is basal, shiny, folded, and bright green except for the reddish lower sheath. Stems are nearly leafless, shiny, and up to 3 feet tall. The seed head is a closed panicle with purplish tinged spikelets. Seed hulls are awned.

Creeping red fescue is extremely palatable at all seasons of the year. It maintains its green color into the autumn, as well as an above average protein content. Ranchers in the Foothills regard it as the best grass for cultivated pasture in their area. It grows well by itself or in mixtures with white and alsike clover. It is essentially a pasture grass as its leafage is too short to be cut and raked readily. In a test undertaken in central Manitoba, cattle preferred it to timothy and brome during October and November.

Chewing's fescue, $F$. rubra var. commutata Gaud. ( $F$. fallax Thuill.), is closely related. However it does not possess extensive creeping rootstocks and its

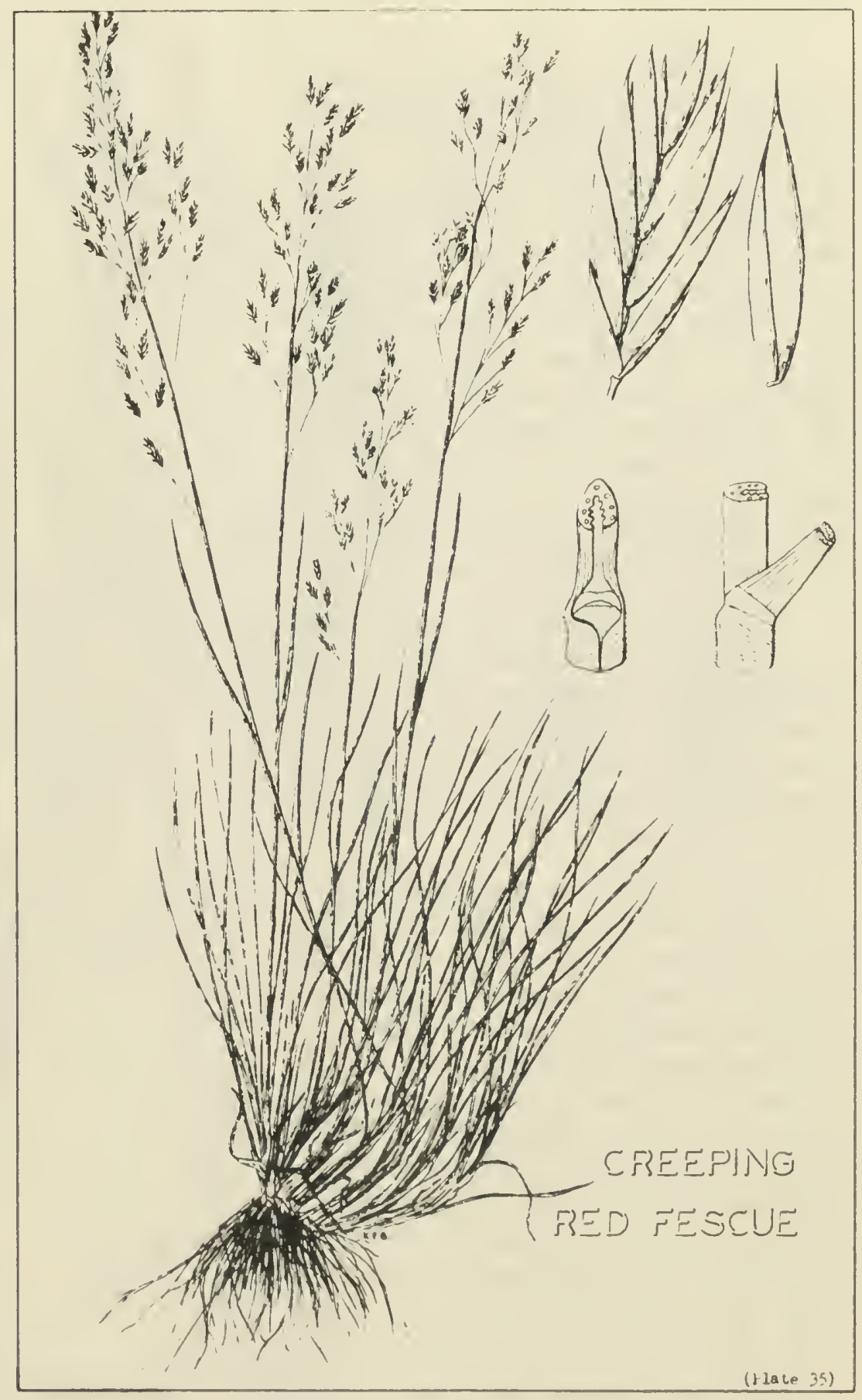

leafage is a brighter green. It is used extensively in lawns, golf fairways, and pasture mixtures. It develops a dense turf which is resistant to grazing, cutting, and trampling. 


\section{Festuca scabrella Torr.}

Rough fescue is a large tufted native bunch grass. It is found as individual plants or in small colonies throughout all plant associations in Western Canada, while dense stands occur in the northwestern section of the Prairie Area, and throughout the Foothills, Cypress Hills, Handhills, and Neutral Hills. Two climatic factors influence its dominance: it is seldom abundant where the annual precipitation is less than 18 inches and where the mean annual temperature is more than $35^{\circ} \mathrm{F}$. The species name, "scabrella", is derived from the Latin word meaning "rough" and refers to the rough edges of the leaves and stem.

Dense, dark green, rough basal leaves produce a bulk of forage, while the tall leafless stems produce easily shed seed. Growth commences early in the spring and seed matures within 90 to 95 days. Individual plants spread from tufts growing at the edge of the crown.

Rough fescue is palatable and is grazed out fairly readily. As the grazing load increases, winter oat grass, shrubby cinquefoil, pasture sage, and other lower producing grasses or weeds become dominant. Management which allows for a complete rest or moderate grazing and haying in a 6-year rotation apparently maintains stands in a productive condition. Rough fescue will cure on the stem, but early frosts may wither the plants before curing is completed. It makes good hay which has a dry matter digestibility of over 55 per cent when cut before the end of July.

The rough fescue which grows in the Cypress Hills has a peculiar protein cycle. Instead of the 16 or more per cent crude protein content possessed by most native grasses during May, rough fescue will not have more than 12 per cent protein. This increases slightly during June, but by August the protein content will be about 7 per cent and seldom more than 4.5 per cent by mid-October. Crude fiber and lignin contents are low, while digestible carbohydrates are

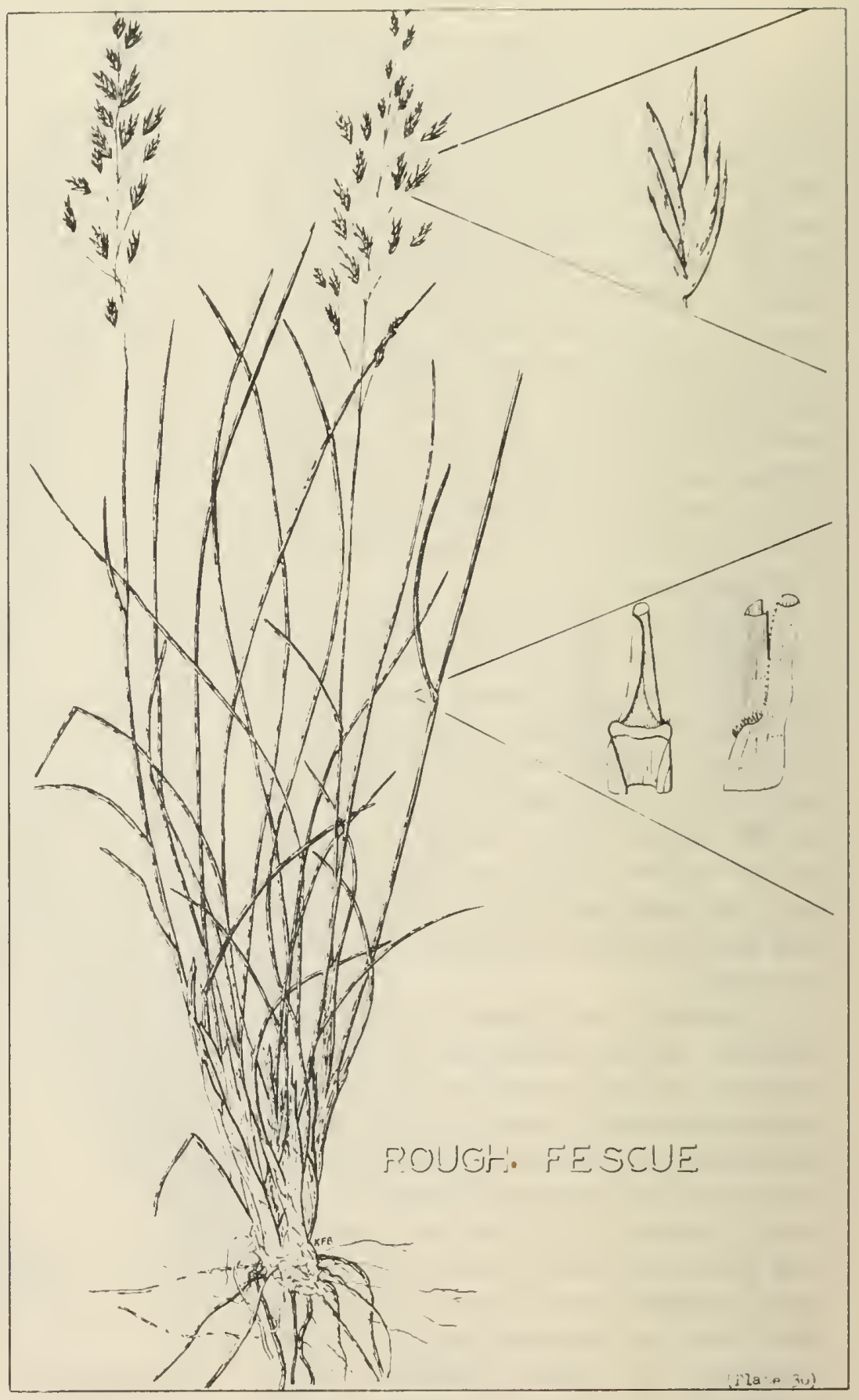

high at all times. The low spring protein content may be the cause of slow spring livestock gains in certain districts where rough fescue is dominant. There appears to be a difference in the forage value of rough fescue from district to district, as rough fescue from the Foothills seems to have higher nutritive ratings than rough fescue from the Cyoress Hills. 
Spangle top is the only representative of the Fluminia genus or group. It is known also as water fescue. It grows along streams and shallow marshes from Manitoba to British Columbia in Canada, and throughout Siberia and Northern Europe. Heavy stands occur in Western Canada in the Qu'Appelle Valley, in Rush Lake near Swift Current, and in small sloughs and shallow lakes throughout the Prairie Area.

Erect, coarse, leafy stems grow from white succulent creeping rootstocks. Some rough, long, green basal leafage develops. The straw-colored, 4- or 5-foot stems bear a feathery whitish panicle which may be a foot long. The oat shaped seeds, $1 / 4$ to $3 / 8$ inch in length, drop from the panicle before maturity. The whitish color of the empty heads identifies spangle top from a distance.

Spangle top requires a continuously moist soil for development, and preferably a deep layer of organic matter on top of the subsoil.It should be flooded until mid-June. Where flooding is for a longer period, then certain sedges, manna grass, and cat-tail will replace it. If flooding is for a much shorter period, either wild barley, alkali grass, or bluejoint will be dominant.

Spangle top makes quite palatable pasture and hay. It can be grazed fairly heavily provided it is rested occasionally, but because of its habitat, it is seldom available for early summer pasture. It should be cut for hay as soon as the water recedes and the land becomes dry enough to carry machinery. Even when cut for hay early in the season, it will be very wasty as the long harsh stems will not be eaten readily. As with all water-loving grasses, its forage is soft, easily destroyed by frost, and does not cure on the stem.

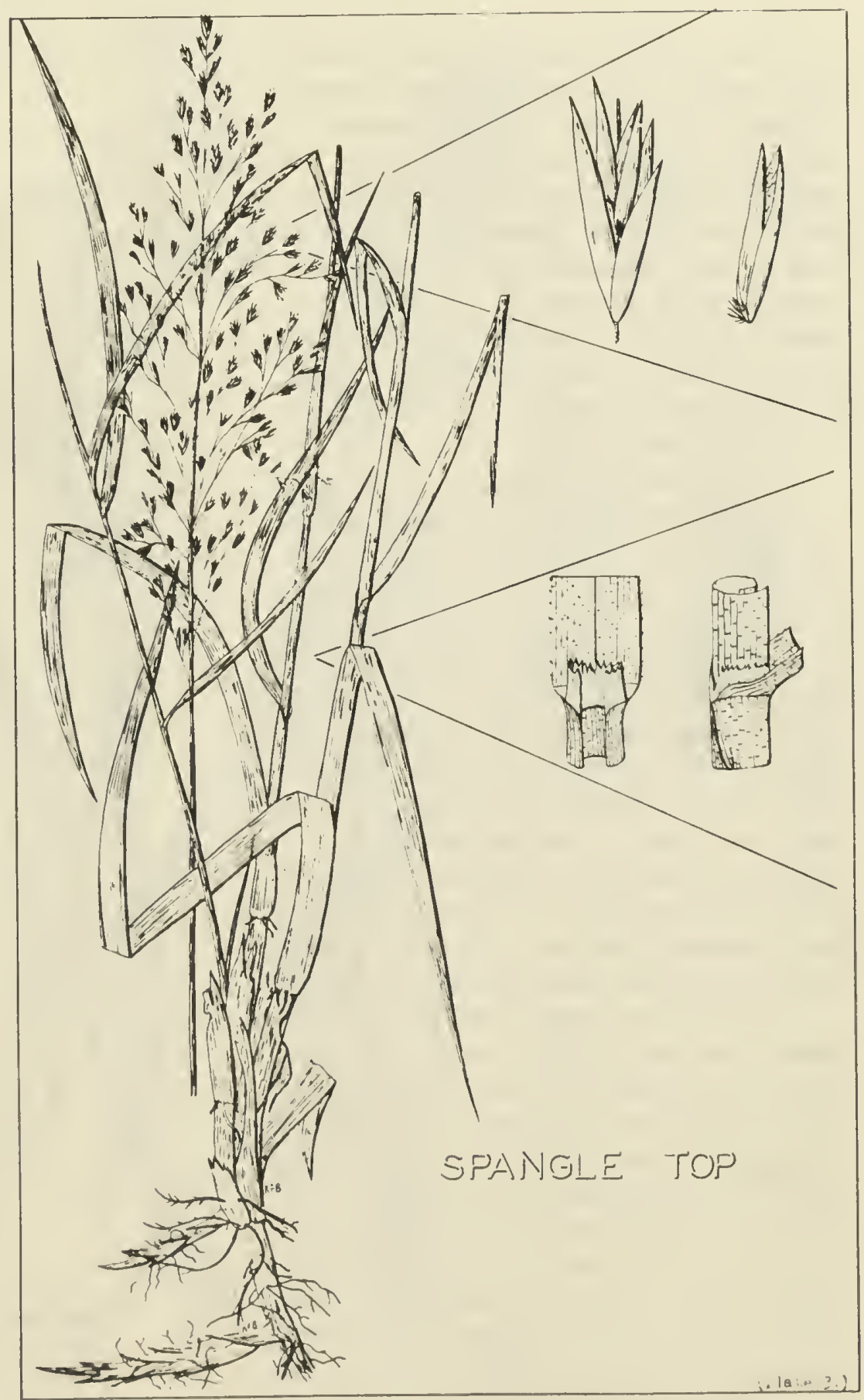

Protein contents are lower than upland grasses except during August and September. 
Glyceria grandis S. Wats.

Tall or American manna grass is the most common of the several manna grasses growing in the Prairie Area of Canada. It has distribution from Newfoundland to British Columbia in Canada, and throughout the Northern United States. In the Prairie Area it is found growing in sloughs and marshes where because of topography the water level will be shallow but continuous from early May to August. It is often found in association with sedges and occasionally in damp shaded ravines.

Tall manna grass may grow to a height of 5 feet from shallow, spreading roots. Firn: green leaves, $1 / 2$ inch wide and up to 1 foot in length, crowd the stem from the base to the panicle, also some basal leafage occurs. Cross lines occur on all leaf parts, and the leaves are folded when young. A large feathery panicle, often purplish and up to 2 feet in length, produces a heavy crop of small hard seeds. There will be from four to seven overlapping seeds per spikelet which shell easily and drop from the plant at maturity. The seed hulls have very prominent nerves, a character which helps identify the manna grasses generally.

Tall manna grass and the closely related fowl and northern manna grass are generally palatable and, because they grow in hard-bottomed shallow sloughs, are available for pasture. The heavy seed crop assures the maintenance of stands unless tramping destroys the water-holding capaciiy of the soil or grazing is so heavy that seed crops cannot be matured. The seed and panicle are eaten readily, and careful pasturing is required to ensure seed replenishments. Its high protein content of 22 per cent until mid-June drops rapidly to 7 per cent by early August. It is low in fiber and high in phosphorus

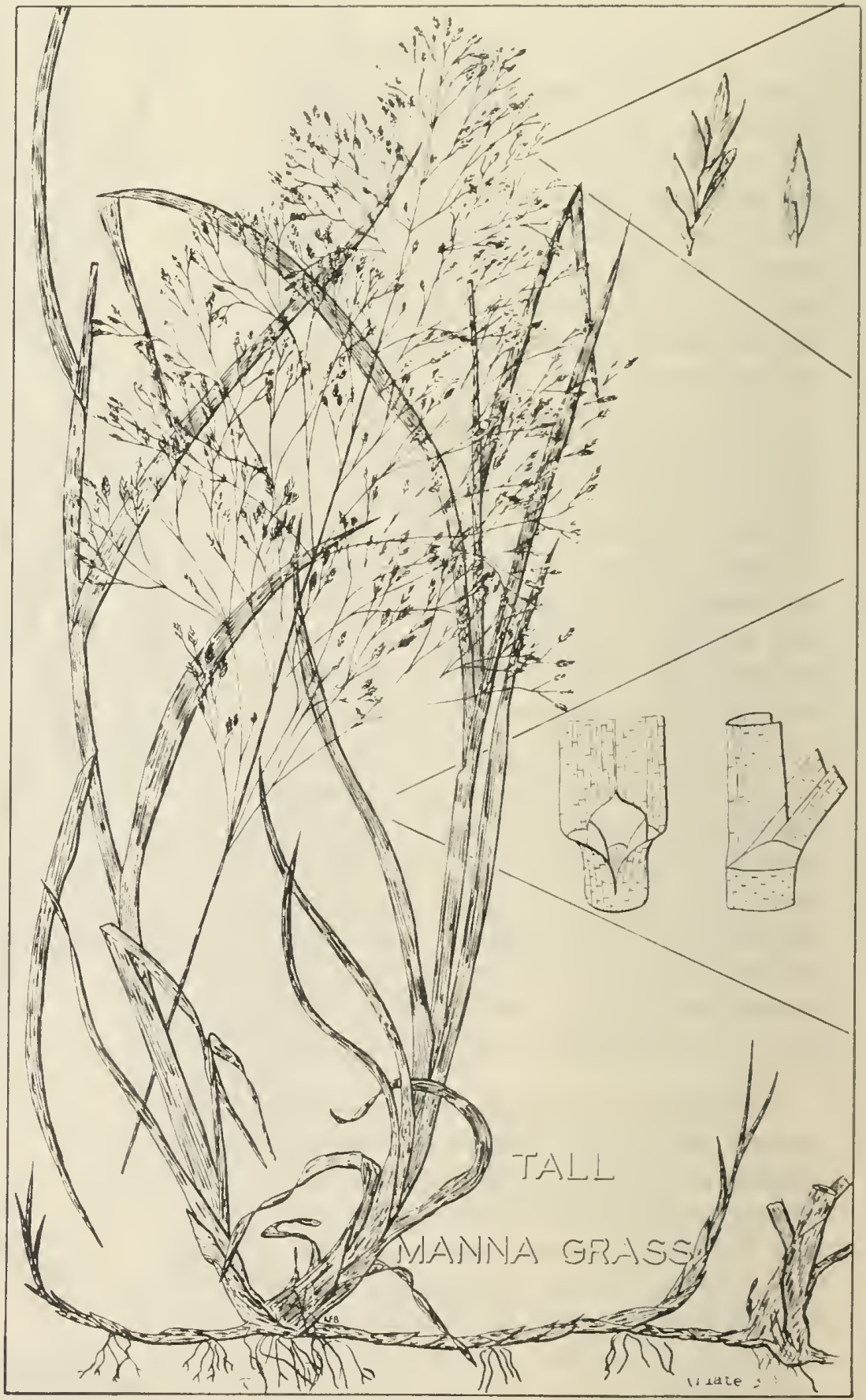

at all times. As with all marsh or slough grasses, its hay is light and wasty. 


\section{SWEET GRASS}

Hieróchloë odorata (L.) Beauv.

There are three species of the Hieróchloë group growing in North America, but the one known as sweet grass is the only representative in the Prairie Area. It has a wide distribution between Labrador and Alaska and southward to Mexico; it is found also in Europe and Asia. The generic or group name "Hierćchloe"" is of Greek derivation meaning "holy grass" and refers to its use in religious festivals to cover floors and porches of churches. In the Prairie Area, sweet grass occurs naturally in low-lying upland, in draws, and throughout abandoned fields.

Sweet grass grows in open stands from slender creeping rootstocks, as well as from seed. Its feeding roots are shallow but numerous. Tufts of short, flat basal leaves surround the stem. The seed head is a shiny open pyramidical panicle. Each branch of the panicle produces several florets, which in turn enclose one perfect and two male flowers. The single seed per floret drops to the ground at maturity, leaving the shiny, bronze-colored glumes on the stem. The entire plant has a sweet odor.

Sweet grass is eaten fairly readily, but is not as palatable as most range grasses. It adds a distinctive and pleasant odor to upland hay and does not transmit its odor to milk. Because its creeping rootstocks fill the soil, it is an excellent grass to help control water erosion.

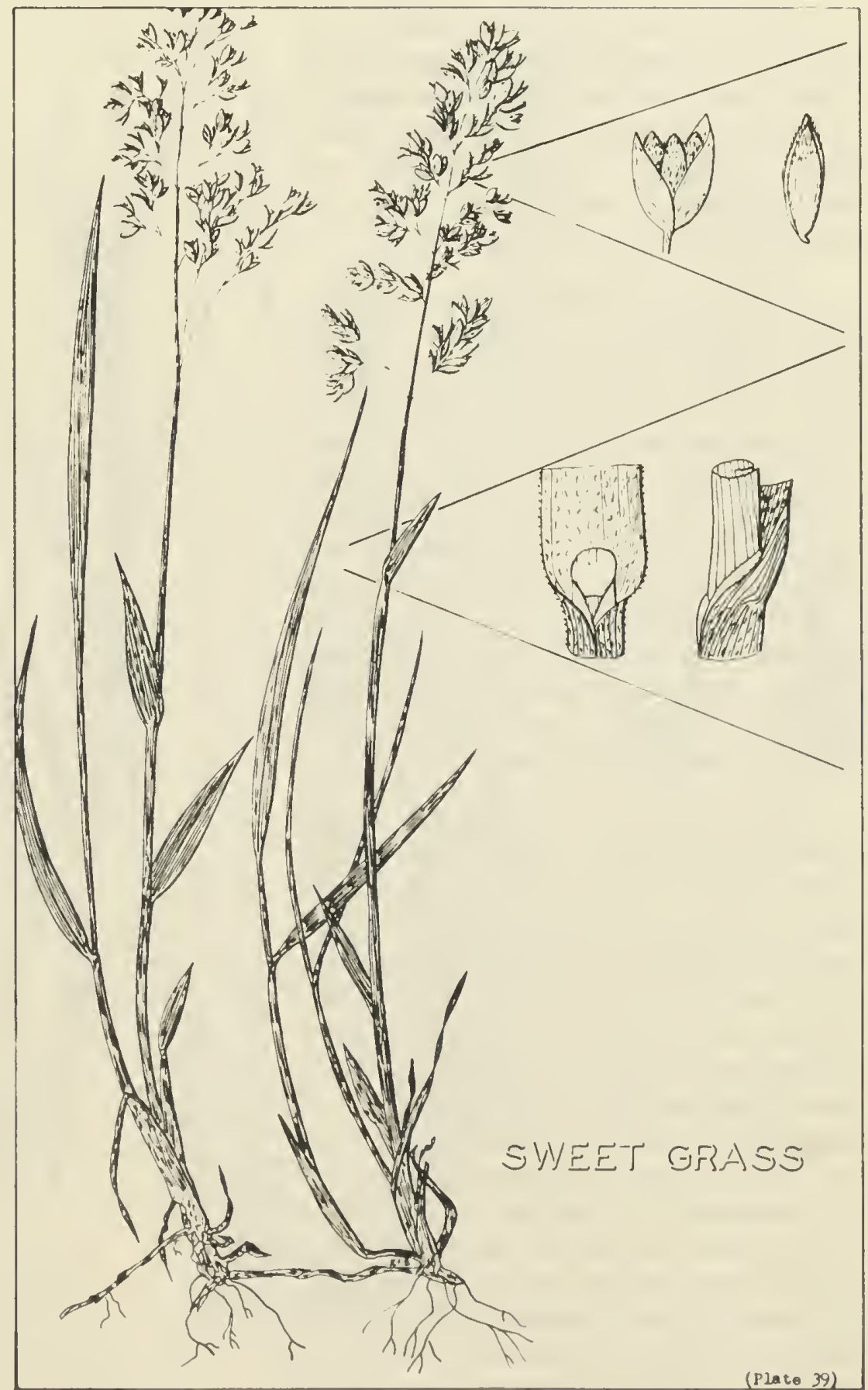




\section{WILD BARLEY}

\section{Hordeum jubatum L.}

Wild barley or foxtail barley is a short-lived perennial closely related to the common cultivated barley. It grows throughout North America in abandoned fields, saline marshes, roadside sloughs, and waste places. It may become a weed in irrigated pastures and hay fields.

Wild barley has a dense shallow root. It produces an abundance of bright green basal leafage and many seed stems which become straw-colored at maturity. The spike has three spikelets at each node, each containing a single seed. Spreading barbed awns from 1 to 2 inches long grow from the tip of the seed, and equally long barbed glumes grow from the base of the seed. The seed head, or spike, breaks up at maturity and is carried by wind, clothing, sheep's wool, and machinery. The plant depends entirely on its bounteous seed supply to maintain its stand.

Wild barley is a palatable forage until the heads form in the sheath. Prior to this date, usually in early June, wild barley produces palatable pasture which has high protein and phosphorus contents and a low crude fiber rating. Around saline sloughs and marshes it grows as the water recedes, and this habit extends the grazing season wherever such conditions occur. It also produces nutritive though low-yielding hay. However, its long barbed awns make it a dangerous hay, because they catch in the gums and other parts of the mouth where they fester and cause smelly and unsightly abscesses. Many farmers and ranchers use wild barley hay regularly during the winter by feeding it in the open on top of snow where the animals have an opportunity to select what theydesire, and the snow in contact with the heads

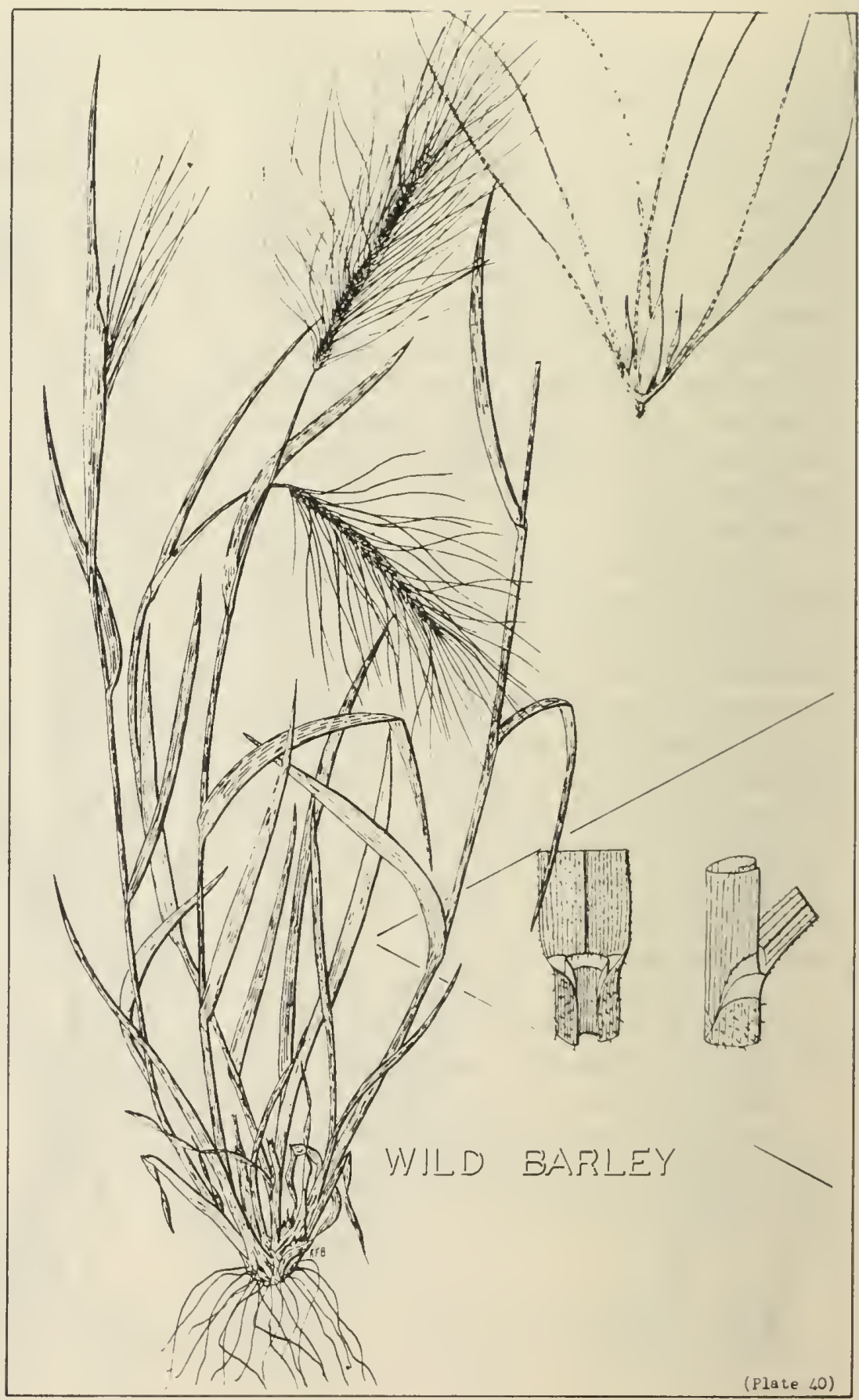

makes them softer and thus more palatable. Cattle can make better use of wild barley than sheep or horses. 
June grass is a long-lived bunch grass native to North America, Eurasia, and Africa. It is found throughout the Prairie Area. In the short-grass prairie it grows in association with blue grama and spear grass, in the Foothills with rough fescue, in open glades in the Northern Boreal Forest with hairy wild rye grass and reed grasses, and with little bluestem in the Interlake Area in Manitoba.

June grass seldom grows in dense stands, but rather as single plants in mixed communities. It is shallowly but densely rooted to a depth of 14 to 18 inches, with a few deeper roots extending 30 inches into the soil. Short, ribbed, flat, dark green leaves grow in tufts, and slender erect, nearly leafless stems grow to a height of from 1 to 3 feet. The head is a closed or tight panicle, almost like a spike or column, that opens during the short flowering season in mid-June. Seed is abundant, usually of low fertility, and matures within 75 to 80 days after growth commences in the spring. Plants vary considerably in the ir appearance under different growth conditions, particularly in height of stem which increases as better growth conditions occur; the short, ribbed, basal leaves are characteristic.

June grass is palatable during the spring and late fall. However, it appears to lose its palatability after the flowering period and until curing is completed. It has a 20 per cent protein content during the the early spring, but this decreases rapidly during June and July to a low of 4.5 per cent by November. Phosphorus, crude fiber, and digestible carbohydrate contents are similar to those of the good prairie grasses. June grass cures on the stem.

There is only one district in the Prairie Area

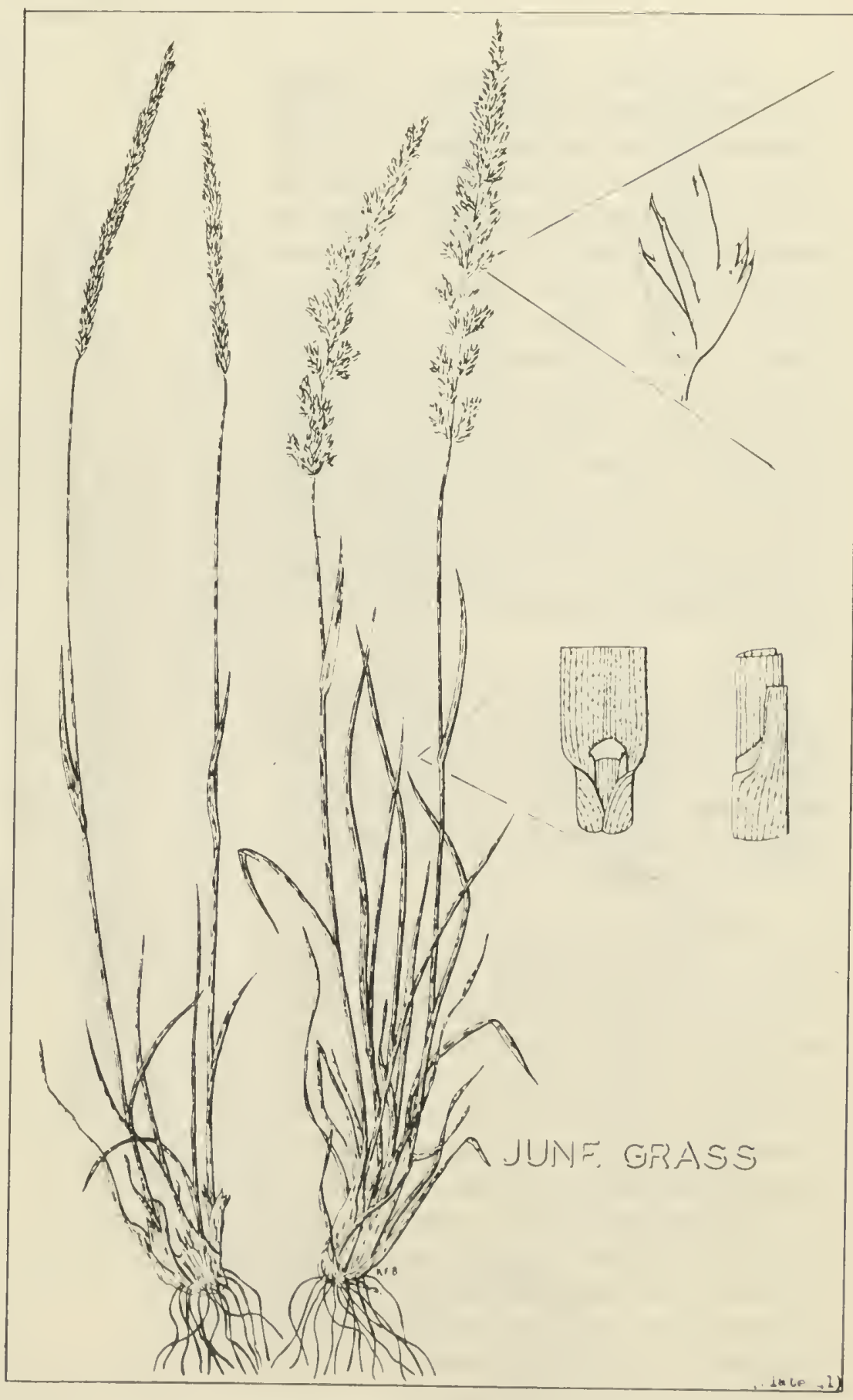

where it is known to be the dominant grass. This district is located between Kindersley and Kerrobert in west central Saskatchewan. 


\section{PERENNIAL RYE GRASS}

\section{Lolium perenne L.}

Rye grasses are natives of Europe and Northern Africa where they have been cultivated since before 1600 A.D. Two species have been imported to North America where they have a fairly wide distribution along the Atlantic and Pacific Coasts; neither will maintain stands within the

Great Central Plains region. The best known of the rye grasses is perennial rye grass, a short-lived perennial which is one of the most important pasture grasses throughout Western Europe, Britain, New Zealand, and the South Atlantic States. The second important species is known as Italian rye grass. It is an annual, but otherwise similar to perennial in appearance and habitat.

Perennial rye grass has been cultivated in Europe for over 400 years, and since 1800 in the Eastern United States. In nrder to produce high yields, it requires a fertile soil, from 30 to 50 inches of rainfall yearly, and a mild climate.

Perennial rye grass is a bunch grass with a relatively shallow root system. Its basal leaves are dense, dark green, glossy, and folded when young. The short stems are nearly leafless and terminate in a spike. The spike might be mistaken for a wheat grass head by a casual observer, but close examination shows that the spikelets are set at right angles to the stem which distinguishes it from other common grasses. Seeds are numerous, about $1 / 4$ inch long, and awnless. This species can be identified from Italian rye grass because of the short awns on the seeds of Italian.

Perennial rye grass is excellent pasture but seldom grows tall enough for hay production. It is commonly grown with white and red clover, and the mixture will often have protein contents in excess

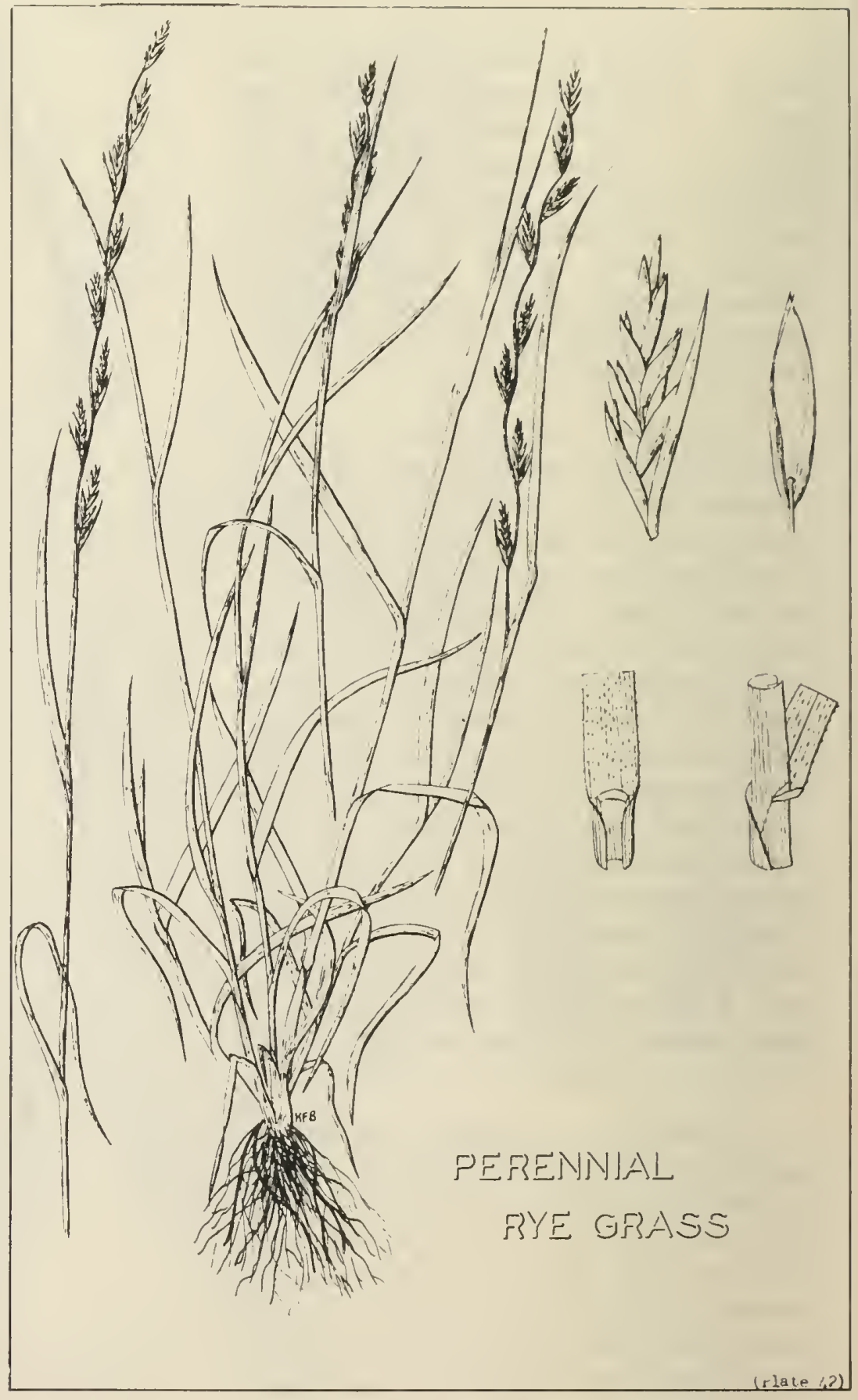

of 30 per cent. Unfortunately, it is dormant during hot midsummer weather, as well as being unpalatable and less nutritious at that time. 


\section{MAT MUHLY}

Muhlenbergia squarrosa (Trin.) Rydb.

Over fifty species of muhly grow in North America. The home of most is along the Atlantic'seaboard and the Gulf of Mexico. Four species occur in the Prairie Area, but only one, mat muhly, is abundant and widespread. Another species, scratch muhly, $M$. asperifolia (Nees \& Mey.) Parodi, grows in dense stands in a few places. One of the largest known surrounds a small saline lake in the center of the Great Sand Hills. In general, muhly grasses are rated as from poor to fairly good forage plants.

Mat muhly is a perennial that occurs throughout Southern Canada and west of the Mississippi River in the United States. In the Prairie Area it is found on shallow, moist, slightly saline soils, as well as on dry upland from the Interlake Area in Manitoba to elevations of 6000 feet in the Rocky Mountains. It will invade eroded sites where better forage grasses cannot establish themselves.

Mat muhly has a dense, shallow root system, as well as fine creeping rootstocks. Dense tufts of short, dull green leaves surround the one to many seed stems. The stems grow in a zig-zag fashion from node to node, and are topped with a slender, interrupted closed panicle. Very little seed is produced.

Mat muhly is not very palatable. Its wiry leaves and stem may be hard to eat off; they certainly are difficult to mow. However, its palatability is undoubtedly associated with the abundance of associated species, because it is eaten when more palatable species are scarce. Mat muhly cures on the stem and is eaten more readily after the first snowfall than in midsummer. Protein and phosphorus contents are somewhat lower

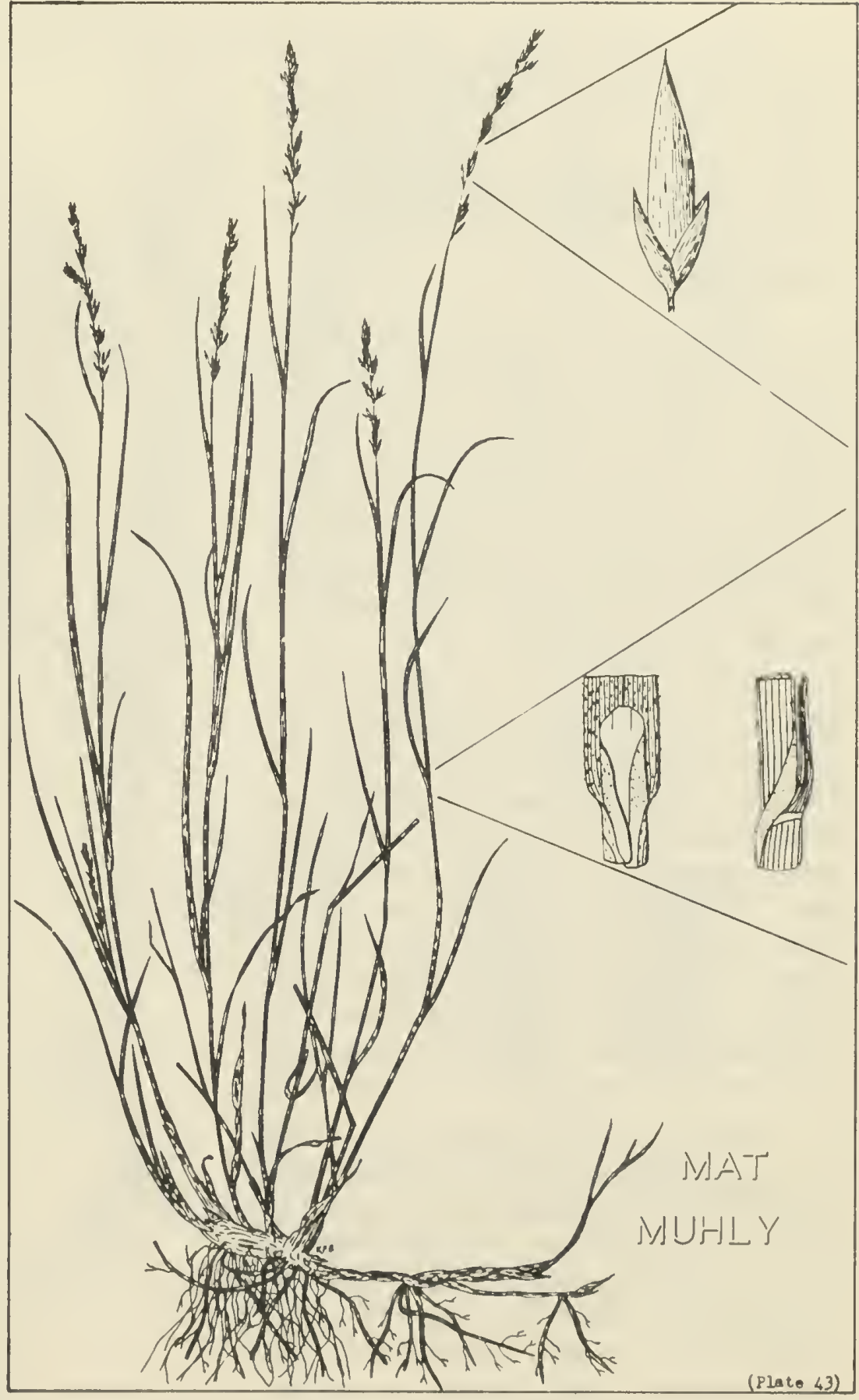

in the spring than those of common prairie species. 
Rice grasses have been named because certain species supposedly resemble cultivated rice. There are twelve species of rice grass growing in North America. Four of these occur in the Prairie Area, but only one, Indian rice grass, is important as a range forage.

Indian rice grass occurs throughout the western half of North America from central Alberta to southern Mexico. In the days of early settlement in Colorado and Utah, it was very abundant and highly regarded as a range grass. Indians ground its plump seed into flour from which they made bread. In the Prairie Area it is common on sandy soils and abundant locally throughout the Great Sand IIills.

lndian rice grass is a bunch grass growing from very deep feeding roots. Its old leaf sheaths persist at its base and help protect the numerous Iong, deep green, folded basal leaves. Leafless seed stalks grow from a tuft of leaves to a height of 2 feet. The feathery panicle has a whitish color caused by the light colored chaff. There is a single round seed per floret which is surrounded with white hairs. The seed itself is black colored at maturity and is tipped with a short awn.

Indian rice grass is rated one of the most palatable of native grasses. Undoubtedly its palatability has contributed to its disappearance. Its green spring growth and lush summer foliage seem out of place on the sand dunes and dry sandy soils where it is most abundant today. It cures well in early autumn to provide nutritious and palatable winter grazing. Its hard seed coat reduces its germination for at least a year after maturity and the hairs which surround the seed have to be processed before it can be seeded

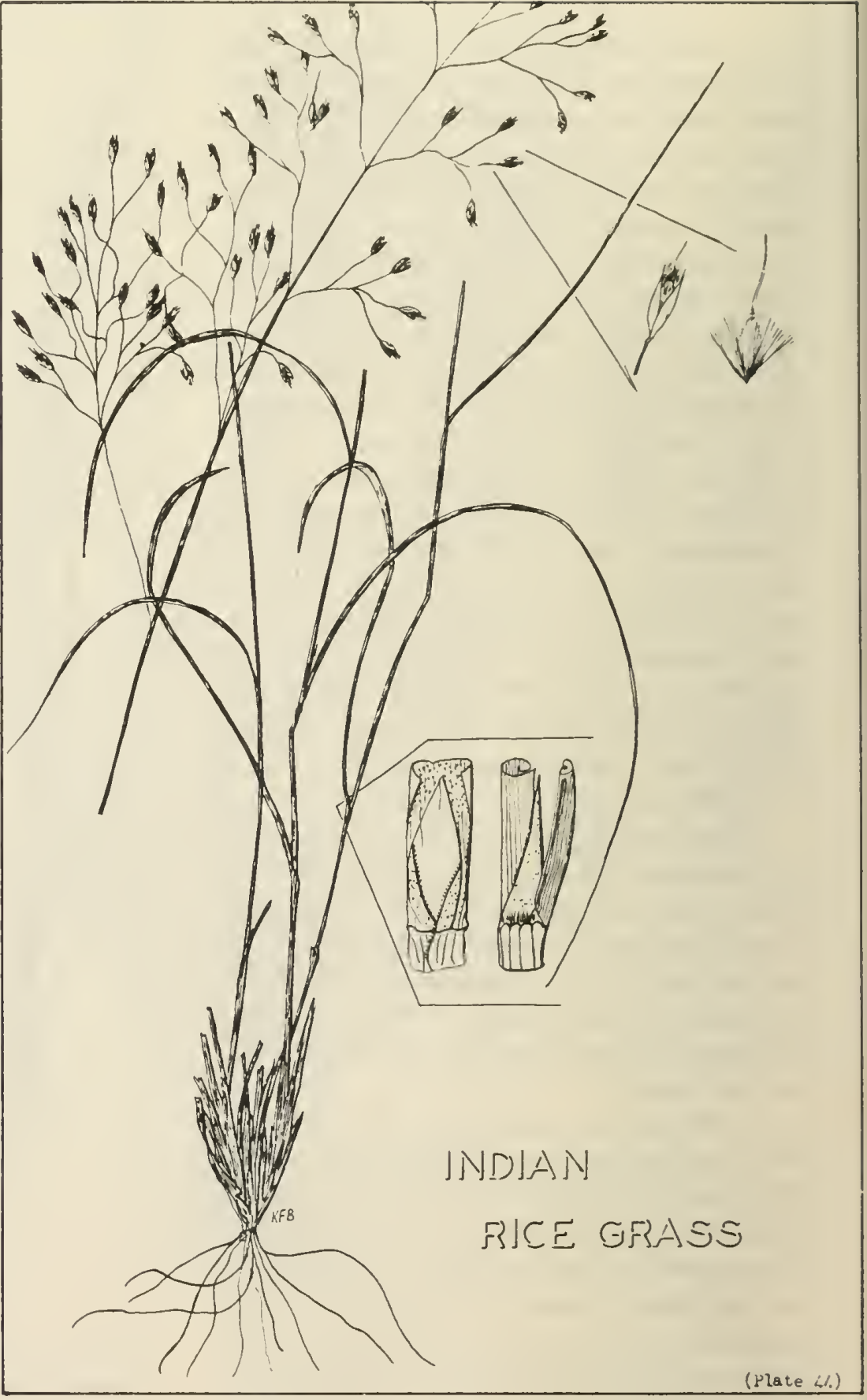

through a drill. Its spring protein content is not so high as its appearance suggests, but it carries a relatively high protein content into the autumn. 


\section{SWITCH GRASS}

Panicum virgatum $\mathrm{L}$.

Panic grasses belong to the millet tribe of plants. There are over 500 different species growing largely in the semitropical regions of the world.

Switch grass is the only member of the panic grass group of importance in the Prairie Area, and then only in Manitoba and Southeastern Saskatchewan. It is also common throughout Quebec, Ontario, United States, Mexico and Central America. It prefers low-lying, moist, light loam soils, but does produce rank growth along streams in districts where it is conmon.

Switch grass is a perennial sod-former growing from short, stout, scaly, creeping rootstocks. Because of its short rootstocks, the stems are crowded and thus a plant often looks more like a bunch grass than a creeper. It has few basal leaves, but long, somewhat bluish-colored stem leaves occur from its base to its panicle. The panicle is feathery and nodding. The single seed per spikelet is small and hard. Germination is usually poor. Strains have been selected for regrassing purposes in Kansas and New Mexico.

Switch grass is palatable when young and is readily grazed until the flowering stage. After this date its harsh, woody stems and leaves are not attractive to livestock if other grasses are available. Good hay can be secured by cutting prior to the emergence of the panicle. This grass was of considerable economic importance during the period of settlement in Manitoba, but it is of little importance today as many of its extensive stands have disappeared into cultivated fields, while overgrazing has reduced its abundance on native sod.

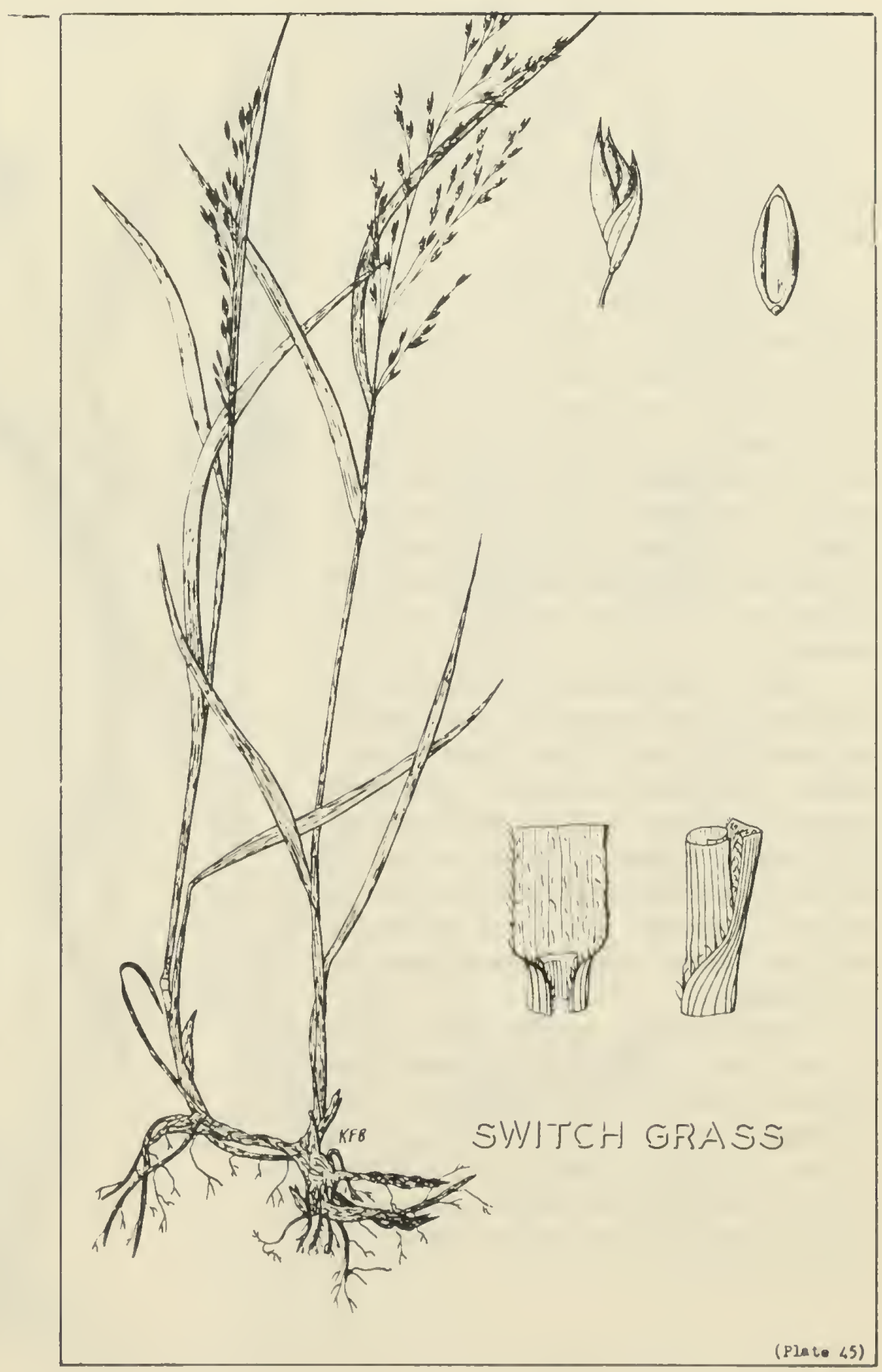




\section{REED CANARY GRASS}

Phalaris arundinacea $\mathrm{L}$.

Reed canary grass is native of both North America and Europe. It was recognized as an excellent forage over 200 years ago in Sweden, and much of the seed used to establish stands elsewhere was imported from that country. It has been grown in Canada for over fifty years.

Reed canary grass grows in clumps which spread by stout creeping rootstocks. Deep feeding roots provide nutrients for a dense cover of long, wide, light green basal leaves and tall leafy stems. The head is a closed panicle, open only during flowering and is interrupted. There is one seed per spikelet, but many spikelets grow on each branch of the head. The outer husks are whitish and shiny, and the enclosed seed is shiny brown, as long as a flax seed but narrower.

Reed canary grass is palatable. It produces good pasture that is eaten avidly, and excellent hay either alone or with alfalfa. Although heavy seed crops are produced, the seed shatters easily making it difficult to harvest with farm equipment. As with all water-loving grasses, its hay is soft and somewhat wasty and is not the hard feed desired to feed range cattle during cold weather.

Reed canary grass will stand ponding for from six to eight weeks, provided the water is not too deep for the leaves to get above the surface, and provided the alkali content of the soil is low. It also grows on upland where 20 or more inches of precipitation occur during its growing season, or under irrigation.

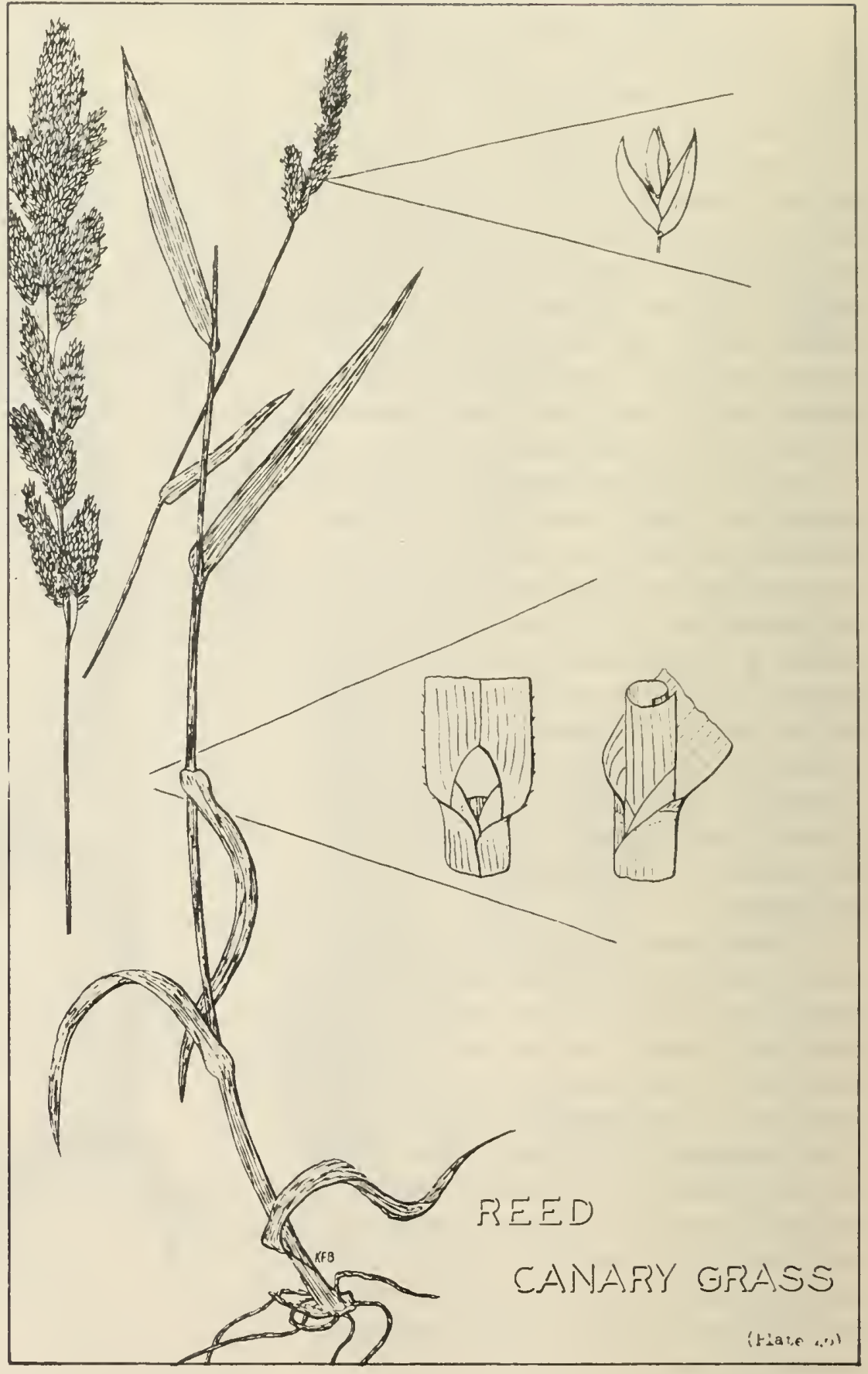




\section{ALPINE TIMOTHY}

Phleum alpinum L.

Alpine timothy is a world wide species growing in mountain bogs and meadows in North America, Europe, Asia, and Africa. Within the Prairie Area it has been collected only in the Rocky Mountains and the Cypress Hills. It has been suggested that the North American type is a different species to that found in Europe. However, the differences are small and most botanists prefer to consider them one species.

Alpine timothy is a shallow rooted perennial with short creeping rootstocks. It has fairly dense basal leafage which is soft and light green in color. The stems are up to 2 feet in height, reclining at their base, and carry a few leaves. The panicle or seed head is tightly closed, about 1 inch in length, somewhat eggeshaped, and bristly. The seed is yellowish, enclosed in urnshaped awned husks, and is slightly smaller than that of the cultivated species.

Alpine timothy is eaten readily by all classes of livestock. It makes a relatively early growth in view of its naturally cool habitat. It is entirely a pasture grass, not only because it grows in places where harvesting equipment would be useless, but its low growth habit makes it difficult to mow and gather. It has a somewhat higher protein content in late summer than its cultivated namesake.

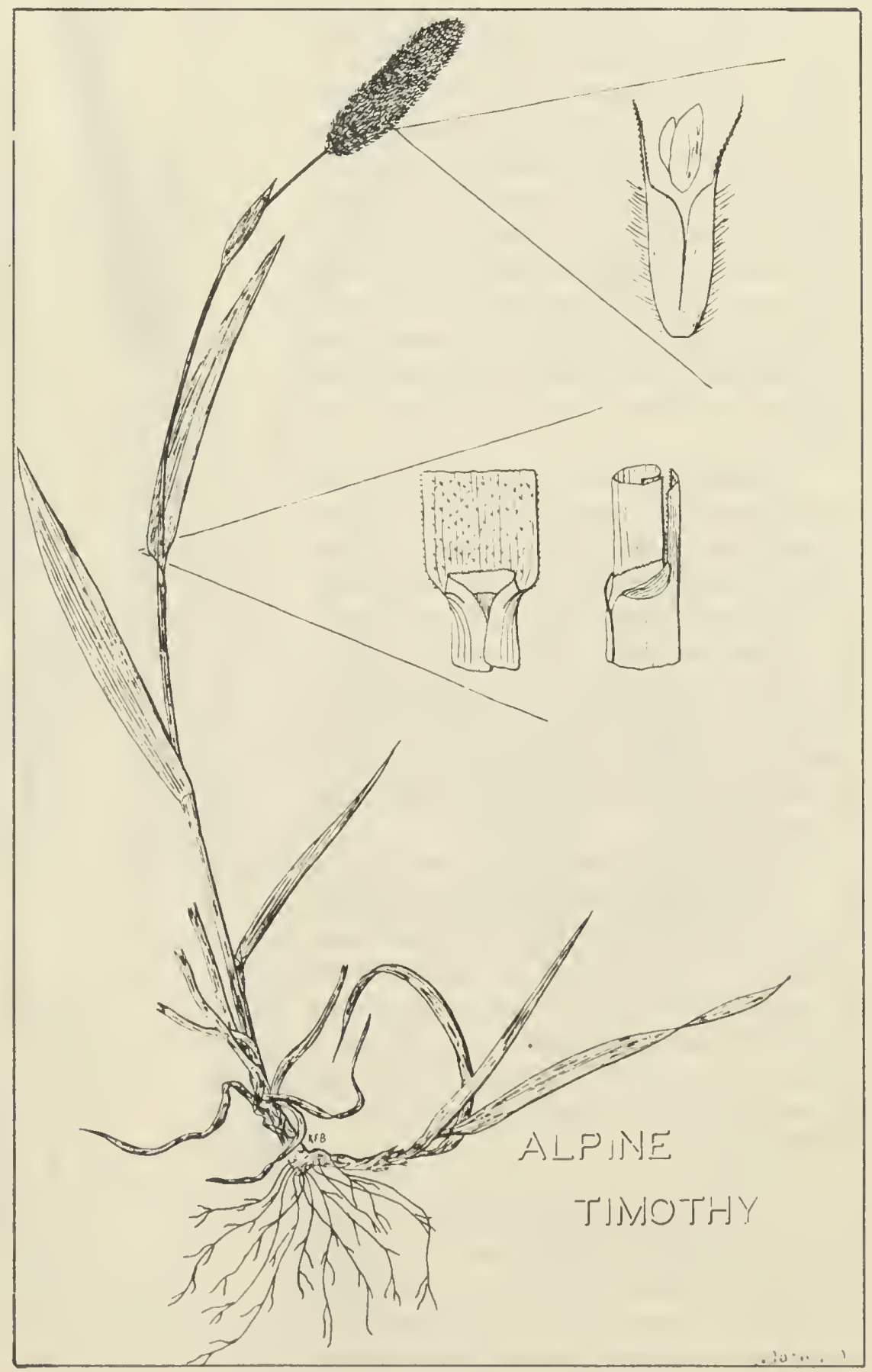




\section{TIMOTHY}

Phleum pratense $\mathrm{L}$.

Timothy was imported into North America in mixed hay or in ballast of ships. However, it was adapted to the New England States and spread quickly. Its forage value was recognized as early as 1750 , when seed was collected from wild stands and sown in cultivated fields. As with all new grasses, it had many local common names, but retained the name timothy from one of the early producers, Timothy Hansen. It moved from New England into Eastern Canada before 1800 and westward as the country was settled.

Timothy has roots extending to more than 4 feet. Its crown consists of a group of bulb-like or swollen sections. These produce a mass of basal leafage and usually one leafy stem which ends in a seed head. All leaves are soft, light green in color and from 2 to 6 inches in length. The seed head is a cylindrical panicle which may be 6 inches long. The single seed per spikelet is small; it is enclosed in an awned urnshaped husk.

Timothy is palatable as pasture and hay. During early growth, it has a protein content of up to 20 per cent, but this drops rapidly to 7 or 8 per cent by the time seed is mature, and to 4 or 5 per cent by late fall. Of all grasses studied in an irrigated pasture test at Swift Current, timothy was the most palatable during its leaf and early stem stage.

Timothy requires considerable moisture supplies to maintain its stand. Then annual precipitation is less than 18 inches, other grasses will produce more and probably better pasture or hay. Ilowever, in areas where moisture is sufficient it will spread from cultivated fields into adjacent range land. This has occurred in Manitoba, along the northern edge of the Prairie Area, and in the Foothills. Unfortunately, many of these stands developed from seed much poorer

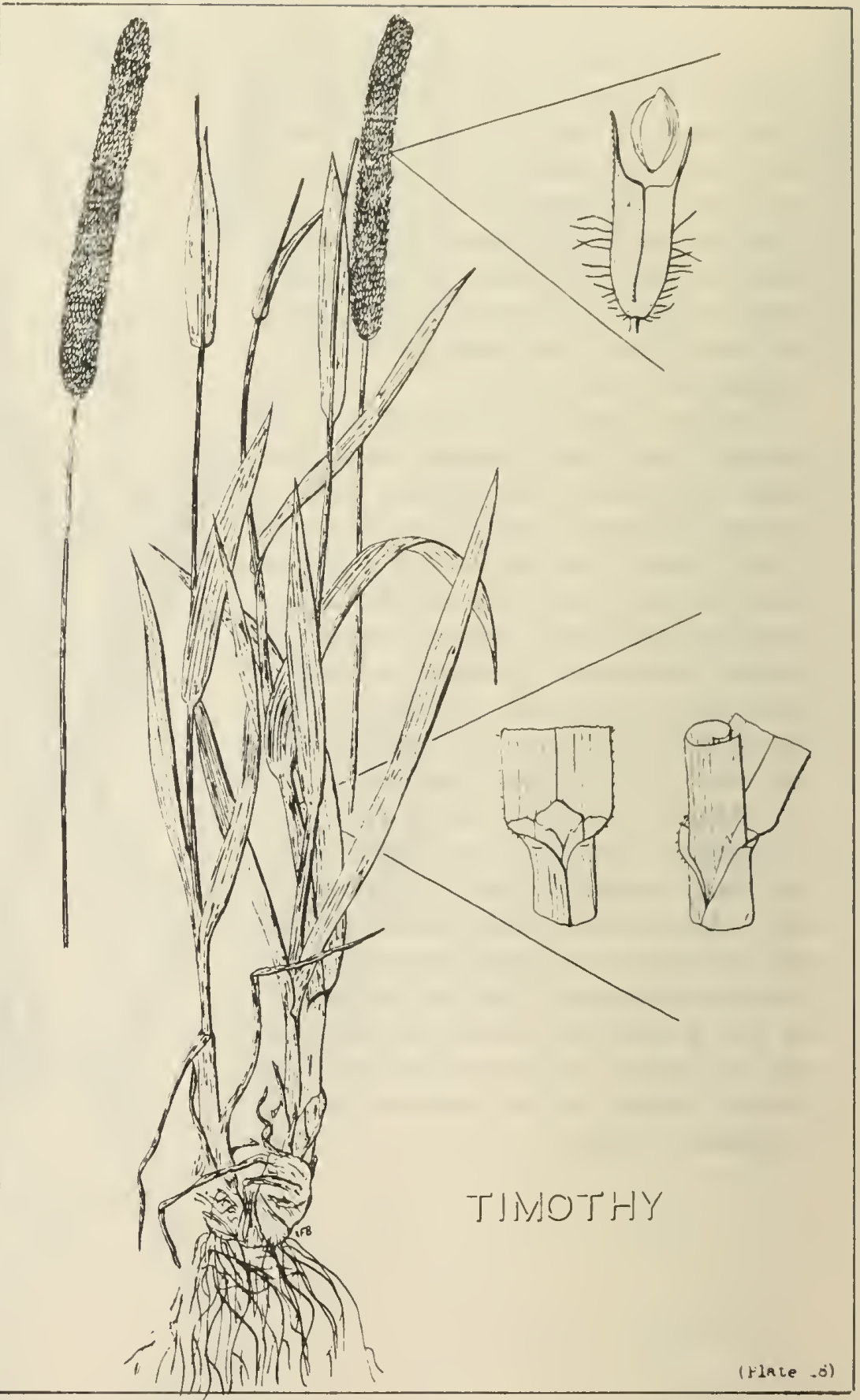

than is available today, thus the quality of the feed produced is lower than that from strains selected recently. Most stockmen like timothy, particularly for spring and fall pasture. 
The blue grass or Poa group is one of the largest amongst grasses. Species are distributed throughout the world from sea level to high elevations in the mountains, and in dry, moist or saline sites. The group is distinguished from other grasses by its boat-shaped leaf tips. Of the nearly seventy species native to North America, some sixteen grow in the Prairie Area; of these, five are important forage grasses, although none are high yielders.

Canby blue grass is a native bunch grass. Its range includes most of Western Canada and the states west of the Mississipi River. In the Prairie Area it is common on slightly saline meadows in the dry central part of the region, but will grow sparsely in dry sloughs and slightly alkaline marshes elsewhere.

Canby blue grass has a relatively shallow root system, not over 2 feet deep. It produces considerable light green, flat, soft basal leafage often covered with gray patches of fungus. The straw-colored stems are seldom over 2 feet in height and end in a short, dense, closed but branched panicle. The seeds are about $1 / 4$ inch in length, narrow, with the hull a shiny straw color.

Canby blue grass is fairly palatable during early growth, but as it grows in fairly open stands it does not produce much forage. It will invade irrigated alfalfa or alfalfa-grass stands where it adds very little bulk and detracts from the nutritive value of the feed. Its protein content drops rapidly from a high of 20 per cent in early spring to 10 per cent by the end of June, and to lower levels late in the season. Its phosphorus content is above average throughout the growing season.

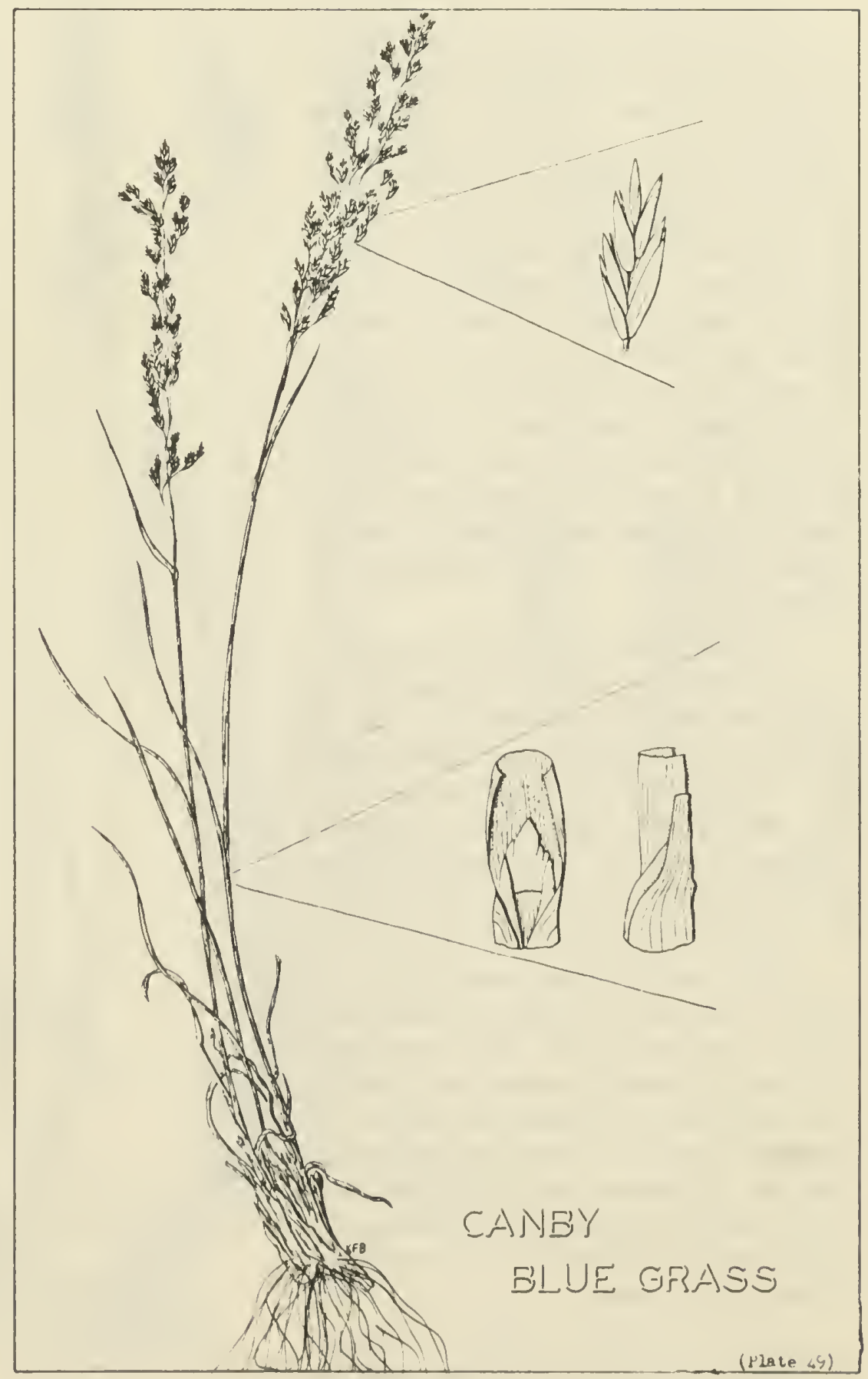


Canada blue grass is a native perennial known also as flatstem blue grass and Virginia blue grass. It has wide distribution throughout all of Canada and the Lnited States, and is an important cultivated grass in Eastern Canada and the States of New York, Pennsylvania, and Maine. In the Prairie Area it is found throughtout western Manitoba and locally in central Saskatchewan and Alberta. It grows on a variety of soils of low fertility or those having poor drainage characters. Its ability to persist and produce on poor quality soils has made it popular for regrassing eroded areas. It requires more moisture than is available in the dry central portion of the Prairie Area.

Canada blue grass has a dense creeping root system, as well as numerous fibrous roots that extend deep into the soil. Its numerous basal leaves are short, folded when young, nearly flat at maturity, and boat shaped. The short stems are flat or compressed and end in a uarrow panicle. Numerous seeds are produced, each with a few cobweb-like hairs at the base.

The short, dense basal leaves of Canada blue grass are quite palatable from early spring until late fall. Under some conditions of growth it makes fairly productive hay, but it is better known for its pasturing qualities of resisting grazing and tramping. In certain areas it is used as a lawn grass and for golf fairways. Occasionally, it is found growing in mixtures with Kentucky blue grass.

Spring protein contents of Canada blue grass are high, 18 to 22 per cent, but the natural seasonal decline will reduce this level to 4 or 5 per cent by October. Observations indic ate that Canada blue grass has some natural curing properties
Poa compressa L.

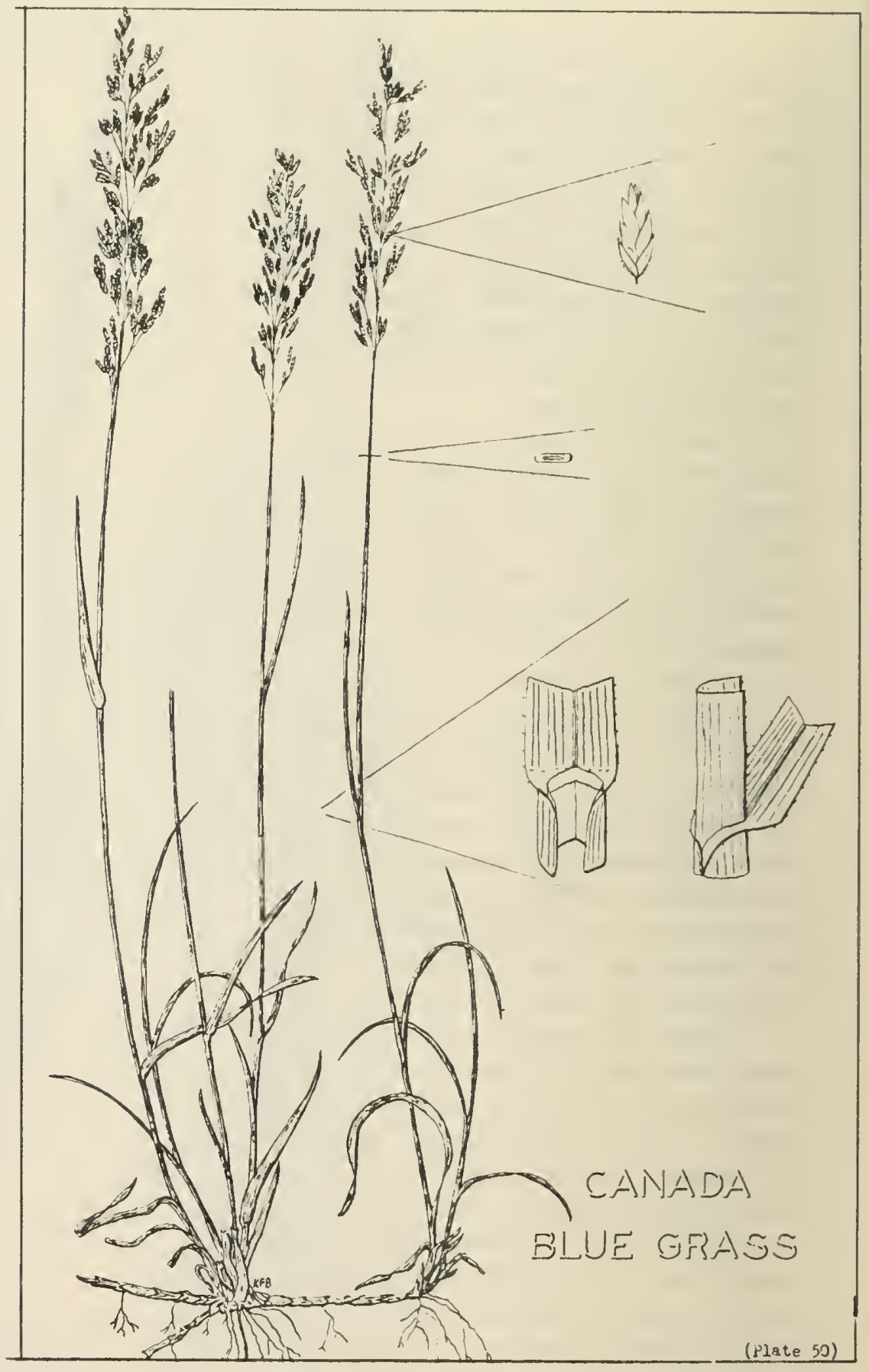

as livestock, and particularly horses, maintain their condition when pasturing it during the autumn and early winter. 


\section{EARLY BLUE GRASS}

Poa Cusickii Vasey

Early blue grass is a native of Western North America, extending westward to the Pacific Coast from Saskatchewan and southward from the Yukon to California and Colorado.' It grows throughout the Prairie Area, although rarely found in the extremely dry central portion. It seldom grows in heavy stands, but rather as individual plants or in small groups amongst the grass and shrub cover.

Early blue grass is a small bunch grass with short dense roots which seldom penetrate more than 12 inches into the ground. Numerous short, very slender leaves grow from the crown, as well as several nearly leafless 2 -foot stems. The seed head is a straw-colored, dense, closed panicle, which produces numerous shiny seeds about $1 / 4$ inch long. During the short flowering period in early June, the head enlarges considerably and becomes almost silvery in color; this character makes the plant easy to recognize.

Early blue grass is palatable only during the spring and early summer, after which it dries up and often withers away. However, during the early season, its rapid growth provides a good bit of fodder and its soft lush leaves are attractive to livestock. Spring protein contents are as high as 25 per cent, but this falls rapidly to 10 per cent by mid-June and to as low as 4 per cent by August.

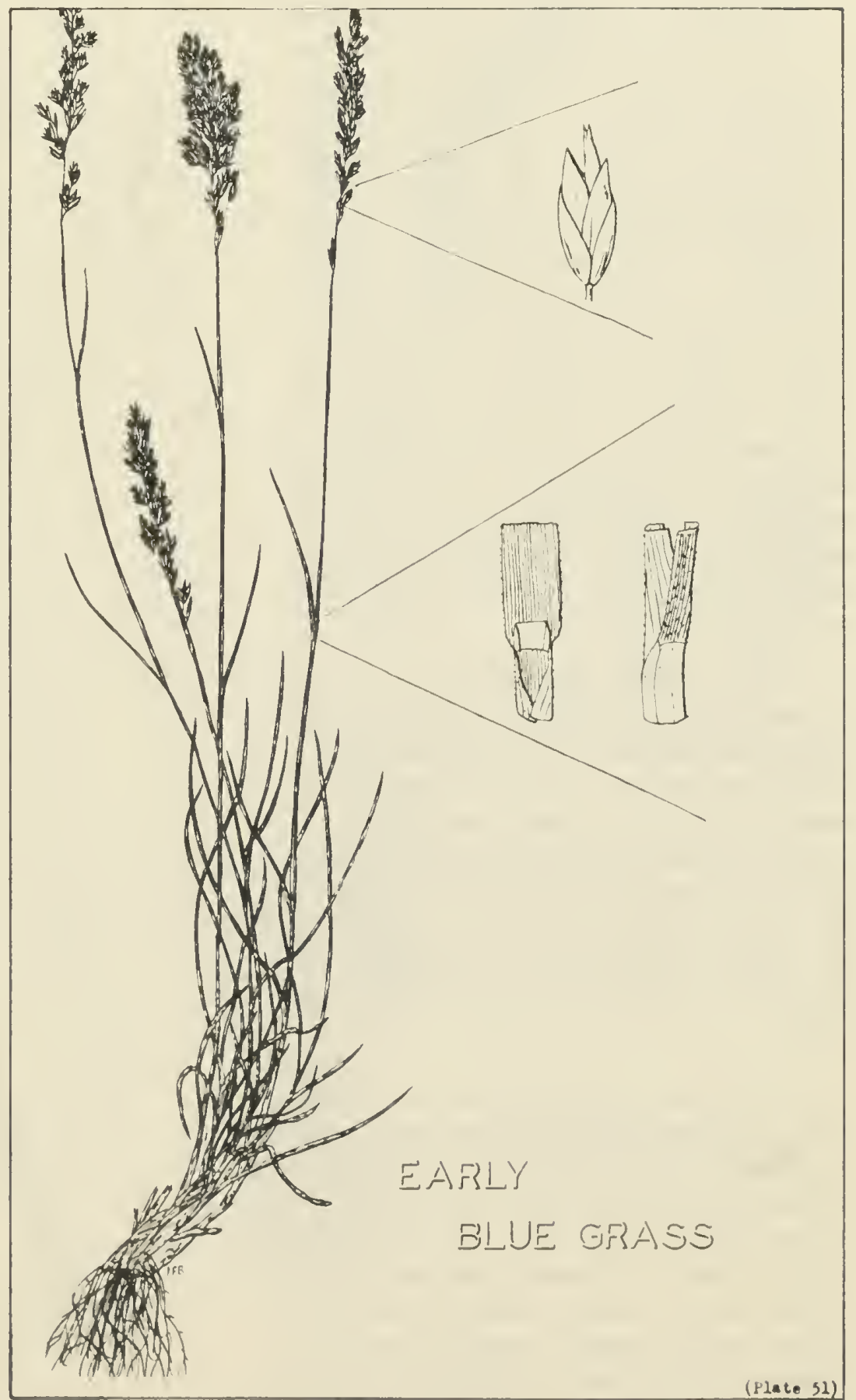




\section{KENTUCKY BLUE GRASS}

Poa pratensis L.

Kentucky blue grass was introduced into America from Europe before 1700, but made slow progress in its establishment for nearly fifty years. However, as settlement moved westward from the New England States, this grass followed so rapidly that the Indians referred to it as the "white man's foot grass". Today the species is widely distributed throughout North America and has invaded range lands to such a degree that it is often considered to be a native. In the Prairie Area it is an important species, particularly in western Manitoba and throughout the transition zone between prairie and forest in central Saskatchewan and Alberta. Elsewhere it occurs in sparse stands along coulees, in brush, and other protected places.

Kentucky blue grass has dense creeping roots which extend its stand, as well as deep feeding roots. Its short boat-shaped leaves are mostly basal, although a few occur on the 2- to 4-foot stem. The flower head is an open pyramidical panicle, usually with five branches at each node; of these the center and outer branches are long and the others short. Seeds are numerous and each has a mat of cobwebby hairs at its base.

Kentucky blue grass has been considered to be one of the best pasture grasses in Eastern North America. However, it requires more moisture than is available in the Prairie Area, and thus has never been popular for pasture purposes where rainfall is less than 20 inches annually. It is the grass commonly used for lawns in Western Canada, and is usually seeded for this purpose in mixture with white clover.

During the spring Kentucky blue grass is palatable and very nutritious. However, unless it is kept grazed down, it soon becomes stemmy and unpalatable. Unless

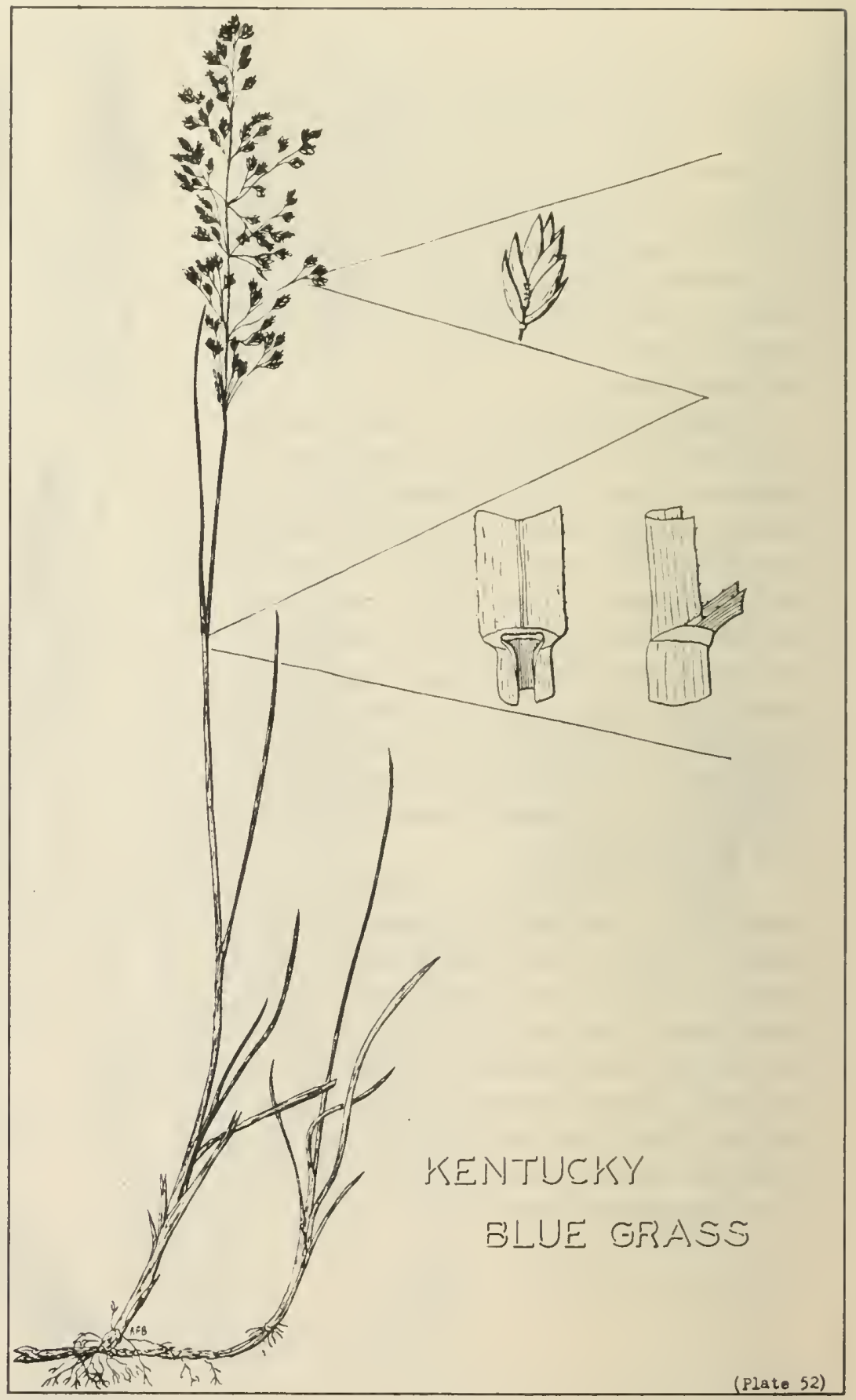

the ground is. fairly moist all the time, the stands become patchy. Protein contents may be as high as 30 per cent for a short time during the spring, but drop rapidly as heading occurs. 
Poa secunda Presl

Sandberg's blue grass is a common native that grows throughout the Northern Great Plains and westward across the Rocky Mountains to the Pacific Coast. Its southward extension continues through Mexico and Central America to the southern tip of South America. It is found throughout the Prairie Area, but is more abundant within the dry central region in southeastern Alberta and southwestern Saskatchewan than elsewhere; in these districts it accounts for from 10 to 15 per cent of the total grass cover.

Sandberg's blue grass is a small bunch grass. Its roots seldom penetrate more than 1. foot into the ground. It has numerous fine, folded basal leaves and a short stem that may reach a height of 12 inches. Its seed heads are closed panicles which are straw colored and shiny when mature.

Sandberg's blue grass makes a rapid growth in late April and early May, often before spear grasses and bluejoint show green. It flowers in late May or early June and matures its seed by early July. Its leaves then wither into whitish clumps; these remain dormant until September when some new growth may occur. It is drought resistant and during dry years spreads as less drought tolerant species die back.

By no standards can it be considered a good forage grass, as its leaves are not very palatable and it is a low forage producer. By mid-June all stock will avoid it, and if plants happen to be grazed after this date they will invariably be dropped from the animal's mouth. Some authorities consider the plant to be a pasture weed because it may increase its stand as better grasses are killed out. During April its protein content may be as much as 25 per cent but this will be reduced to 5 per cent by

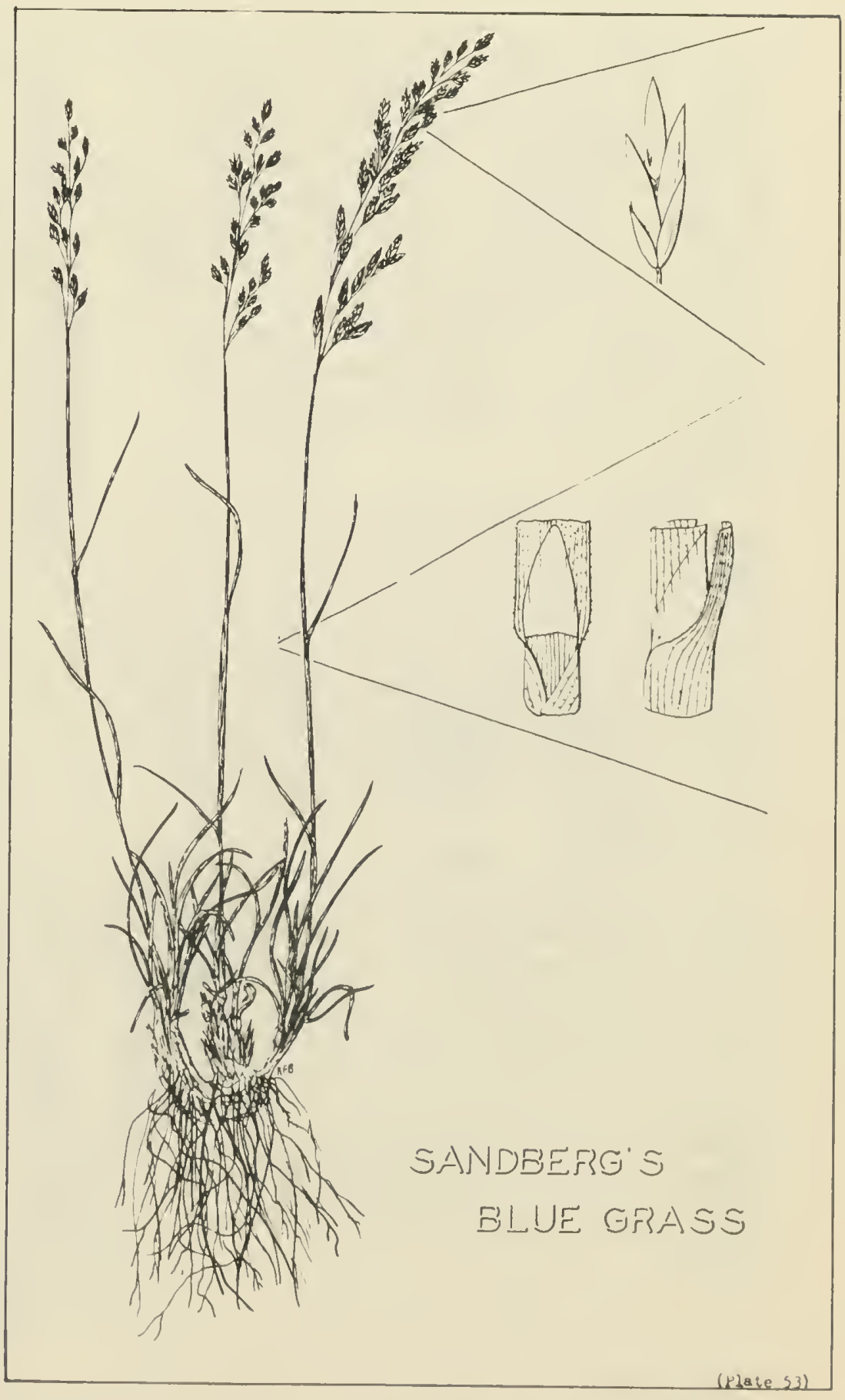

early July. Its extremely early growth, and greenness when all other grasses are still dormant, help to identify Sandberg's blue grass. 
Nuttall's salt-meadow grass has a range that includes the western half of North America, as well as the States of New York and Maine and the Maritime Provinces of Canada. It is quite common throughout the Prairie Area where it grows in saline soils with high water tables. The most extensive stand known occurs on the strip of low-lying land connecting Lakes Chaplin and Old Wives in southern Saskatchewan, where it grows in association with the poisonous seaside arrow grass, Triglochin maritima L.

Nuttall's salt-meadow grass is a perennial bunch grass with a relatively shallow root system. Numerous fine, flat short basal leaves grow from the crown. From one to ten stems grow to a height of 2 feet. The very open pyramidical panicle produces a considerable seed crop with from four to ten seeds per spikelet. The seeds are small and overlap each other in the spikelets.

Nuttall's salt-meadow grass is quite palatable in its early growth stages. As maturity advances palatability declines. In some districts this grass is harvested for hay, but its low yield in most areas makes it an expensive feed. Further, it has a relatively low protein content at maturity, as well as being high in ash and fiber. Because it grows in stands with poisonous plants, heavy pasturing may result in livestock losses caused by the associated species.

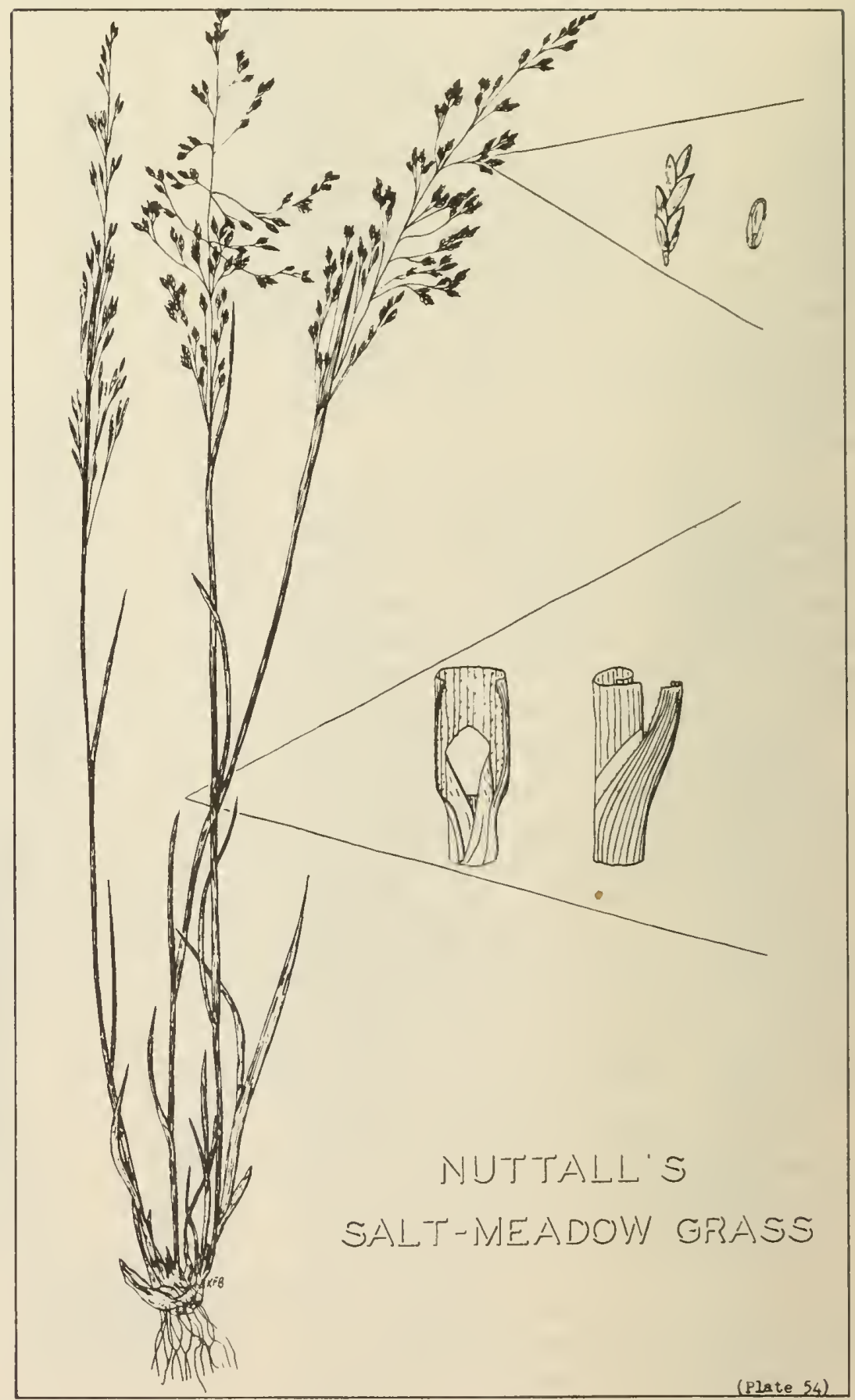




\section{PURPLE OAT GRASS}

\section{Schizachne purpurascens (Torr.) Swallen}

The purple oat grass group is represented by a single species in North America. This species has a range from coast to coast in Canada, but is rarely found west of the Rockies in the United States. The name Schizachne is derived from Greek words and means "split chaff", a reference to the split end of the seed husk.

Purple oat grass, also known as false melic, is a shade-loving grass. It grows only in forests, and is more common in coniferous forest areas than in those where broad-leaf trees are dominant. Thus in the Prairie Area it is found only at the northern and western boundaries of the area and throughout the Cypress Hills.

Purple oat grass is a spindly bunch grass with a shallow, sparse, and rather coarse root system. The 3 - to 4 -foot stem arises from a few, flat, lax basal leaves. Usually a single leafless stem grows on one plant. The panicle is open, purplish in color, and with a few flowered drooping branches usually in pairs. Long awns extend beyond the seed hull.

Purple oat grass is not an important forage grass. It is seldom abundant as it grows as single plants amongst the cover. Its yield is low and the grass itself is light, that is, it will have a high water content when growing. No palatability rating has been assigned to this species, but observations suggest that it is only moderately palatable. Protein contents are low and fiber contents high at all stages of growth.

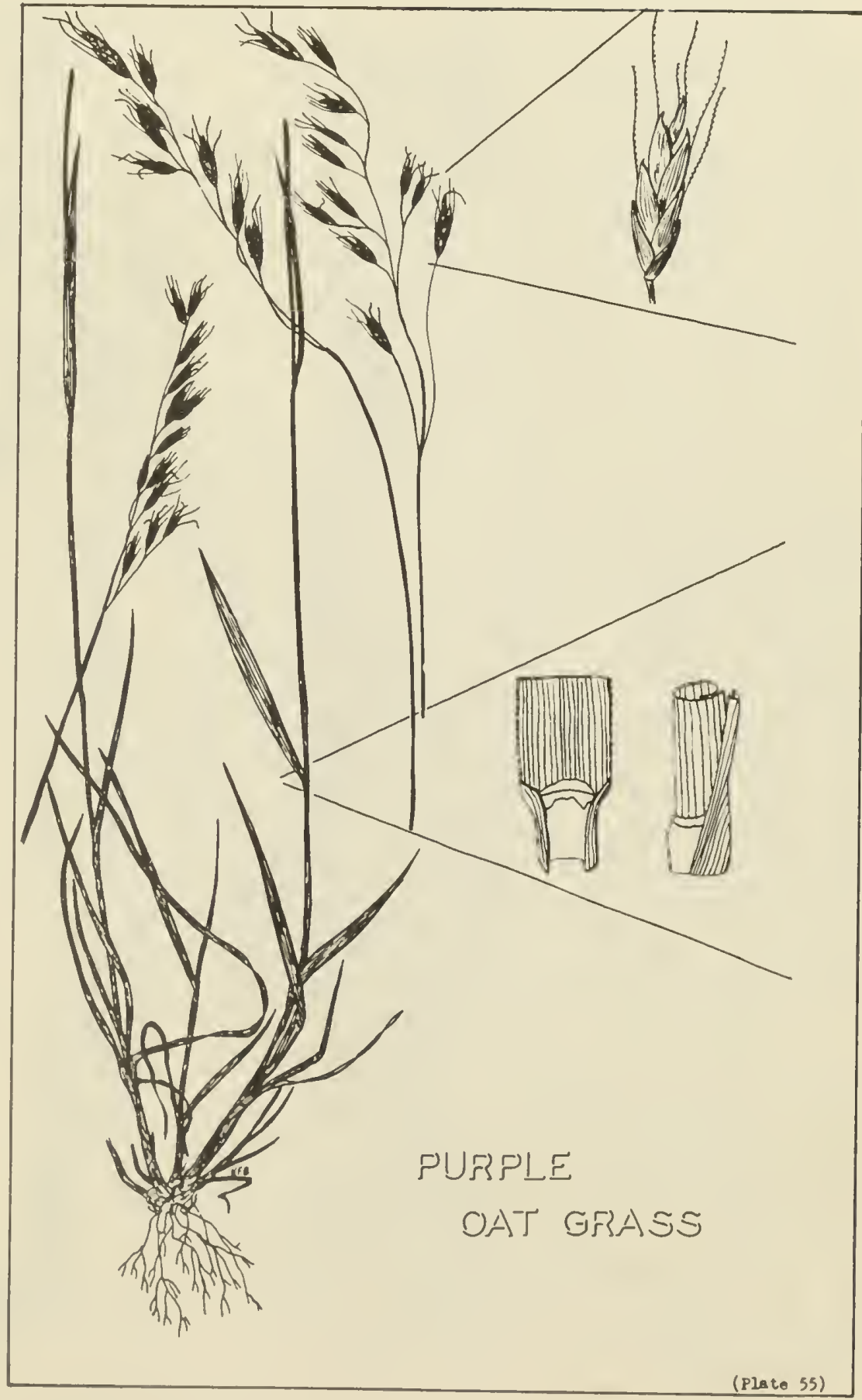


Indian grass species are generaily warn weather grasses growing in the eastern half of North America. Only one species occurs within the Prairie Area, and its range is within the drainage basin of the Red River in Nanitoba. The genetic or group name "Sorghastrum" literally means "a poor imitation of sorghum". The name is quite appropriate because plants resemble tall spindly sorghums, while their feeding values are relatively low after maturity.

Indian grass is one of the common grasses which compose the cover in the area adjacent to the Red River in Nanitoba. The associated grasses include big and little bluestem and switch grass.

Indian grass is a creeping-rooted species. In addition, it has a dense, deep root system for feeding itself. Leaves are relatively few, flat, tapering to a point, and as much as $l$ foot in length. The leafy stems may be as much as 7 feet tall, but are usually about 3 feet in height. Seed heads or panicles are from 6 to 14 inches in length, quite bushy, dense, and usually yellow. A large quantity of seed is produced. The $1 / 2$ inch awns which extend from the seed hulls give a bristly appearance to the panicle.

Indian grass is palatable in its early stages of growth. However, as with most other coarse grasses, it loses its tastiness and feeding qualities after heading occurs. Protein content drops from 18 per cent in early spring to 6 or 7 per cent by August, while fiber increases from about 25 to 35 per cent during the same period. Frost destroys its nutritive qualities. It does not cure on the stem.

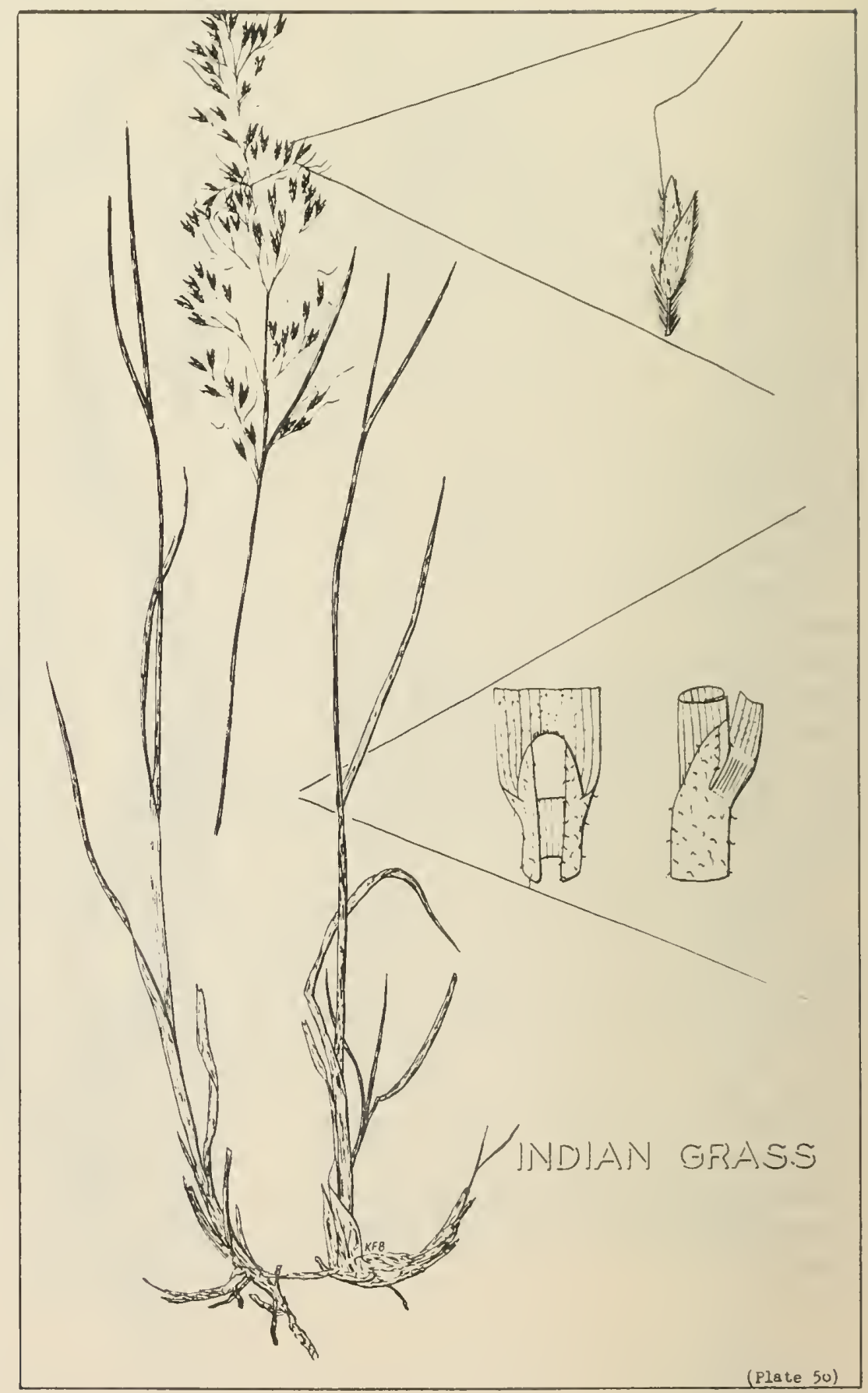




\section{ALKALI CORD GRASS}

Spartina gracillis Trin.

Cord grasses are found throughout the world. They have taken their name "Spartina" from the Greek word "spartine" which was a type of tough cord. Because certain species are very salt tolerant, cord grasses have been planted in the estuaries of rivers where they help to bind the sand and actually build land by catching floating soil and debris.

Alkali cord grass is a native whose range extends between the Red and Mississippi Rivers and the Pacific Coast. In the Prairie Area it is found in sandy saline flats, around the borders of alkali sloughs, and along shallow streams where drainage is poor. The largest known pure stands grow on the extensive flats of the Great Sand Hills in western Saskatchewan.

Alkali cord grass has strong, scaly, creeping roots, as well as a deep feeding root system. Basal leaves are long and tough, and have tiny saw-like teeth along their edges. The seed stem is 3 to 4 feet in height. The flower head consists of from four to eight spikes which cling to the wavy stem. Each spike consists of up to forty pairs of closely packed spikelets, all growing on one side of the spike and away from the stem.

Alkali cord grass is not particularly palatable in any stage of growth. Its protein content is comparatively low at all seasons of the year and conversely its fiber content is extremely high - over 40 per cent at maturity. Despite its harsh characters, it is used as hay in areas where it abounds and livestock winter on it fairly well when

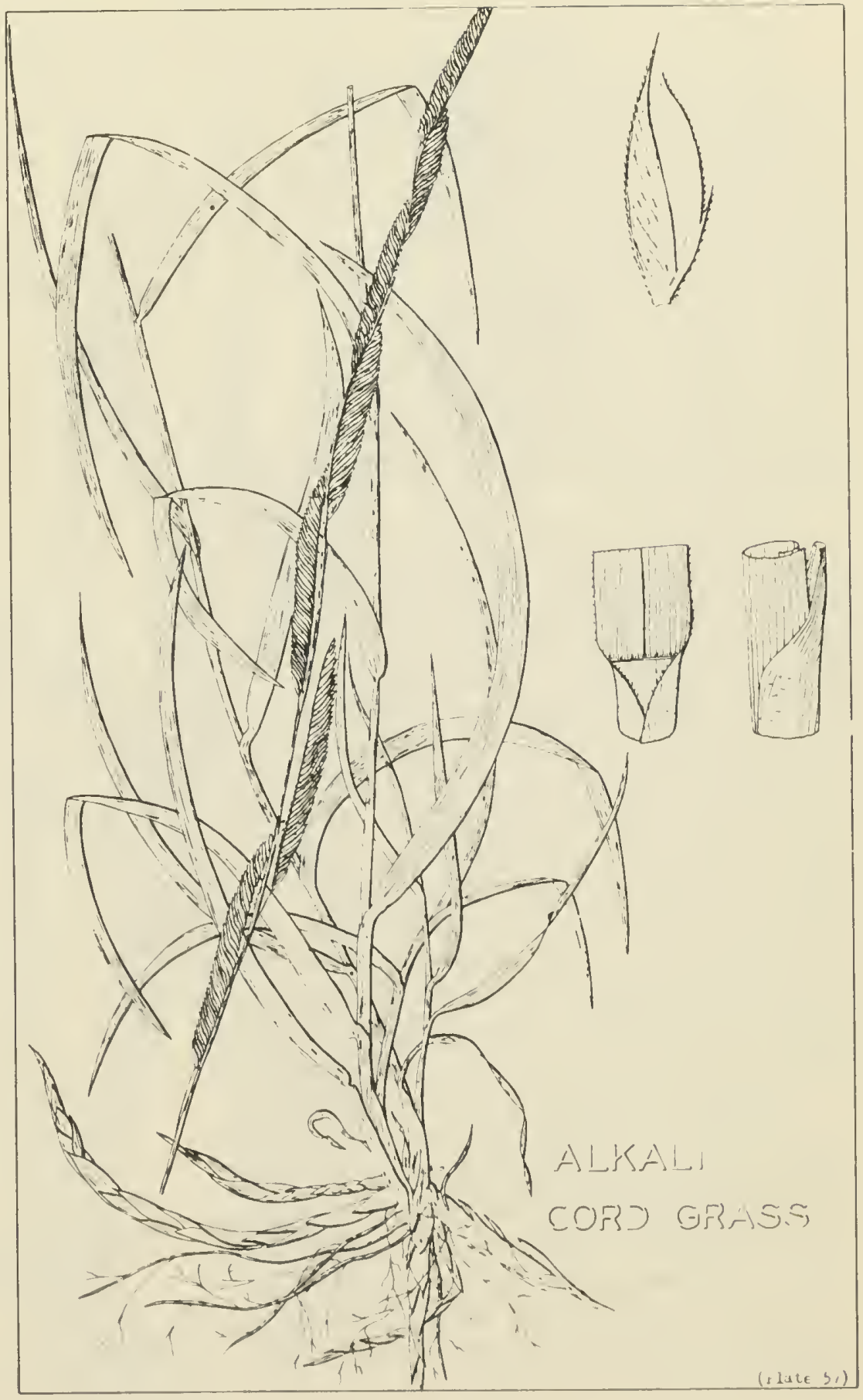
supplemented witl grain and alfalfa.

Various attempts have been made to regrass alkali cord grass flats with more palatable forages. However, no other species has established equivalent

stands, and in fact very few of the cultivated grasses will even grow under the saline conditions wherc alkali cord grass thrives. 


\section{PRAIRIE CORD GRASS}

Spartina pectinata Link

Prairie cord grass is a grass of fresh water marshes, although there are stands extending into brackish marshes along the Atlantic Coast. This grass has a limited range within the Prairie Area. It develops alnost pure stands in marshes along the Red River and its tributaries, and occurs in mixed stands with big bluestem, switch grass, and Indian grass on adjacent uplands. It is common in the area known as the Interlake Region in Manitoba. A few small stands occur in Saskatchewan as far west as Swift Current.

Prairie cord grass develops thick stands from thick, scaly, creeping roots. Its feeding roots are dense and may extend 6 feet into the ground. Dense stands of basal leafage are often 2 feet in height. The leaves themselves are wide at their base but converge to a pointed tip, their edges are rough, and as the leaves dry up the edges roll inward to form a tube. The heads consist of from ten to twenty spikes which cling to the main stem. Each spike is composed of up to forty pairs of spikelets, all growing on one side of the spike and away from the principal stem. Awns extend from the seed hulls to give a somewhat bristly appearance to the spikes.

Prairie cord grass is seldom grazed if other forage is available. However, it will be eaten or at least the upper part of the leaves will be grazed while stock seek food in the shallow water where it grows. Large quantities are cut for hay in central Manitoba, but this hay requires grain supplements to keep livestock healthy.

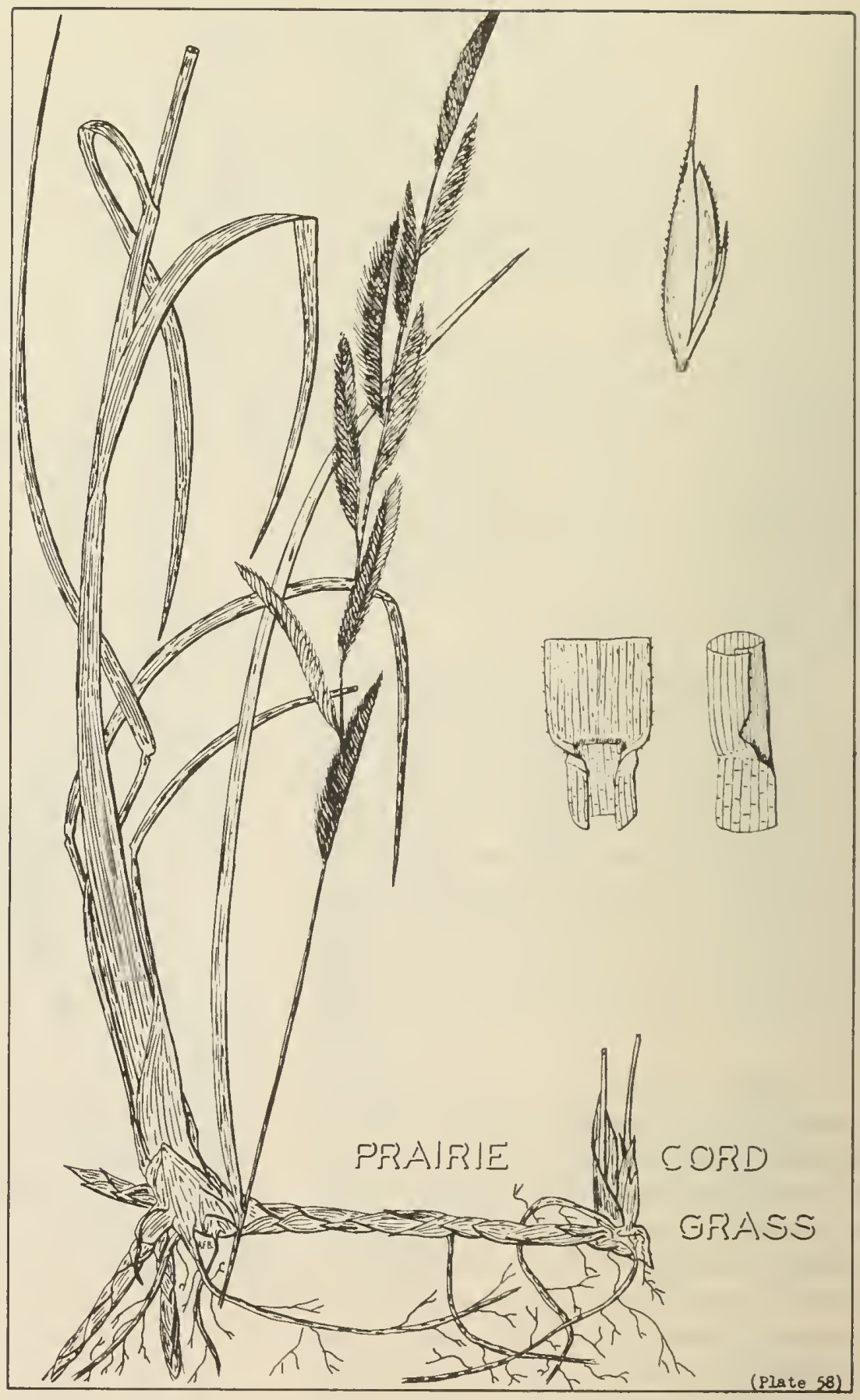




\section{SAND DROPSEED}

Sporobolus cryptandrus (Torr.) A. Gray

The dropseed group contains nearly forty species native to North America. However, they are generally southern grasses and only three are known to occur in the Canadian section of the Northern Great Plains. The group name "Sporobolus" means to "cast or drop a seed" and refers to the habit of shedding seed before maturity.

Sand dropseed has a wide distribution throughout Southern Canada, the United States, and Northern Mexico. In the Prairie Area it is often the dominant grass on stabilized sand dunes, while sparse stands are found in all areas with sandy soils. Heaviest known stands occur in the Great Sand Hills and along the Qu'Appelle River. It is the most abundant and only important "dropseed" growing in the Prairie Area.

Sand dropseed is a small bunch grass with roots that extend to a depth of 4 feet. Its leaves have a tuft of white hairs where the sheath and blade meet. It has solid stems which are often 3 feet tall. The seed head is a closed panicle when it emerges from the leaf, but opens into a pyramidical inflorescence at flowering. The panicle has single branches at each node, each spikelet contains one seed only.

Sand dropseed is rated as highly palatable in the Southern States, but only moderately so in the Prairie Area. It starts growth about mid-May, later than associated species, and matures its seed before the end of July after which the leaves cure. Unlike most grasses, sand dropseed is unpalatable after curing occurs. Protein contents are nothigh at any stage of growth and fiber contents are higher than for blue grama grass or other short-grass prairie species. An important

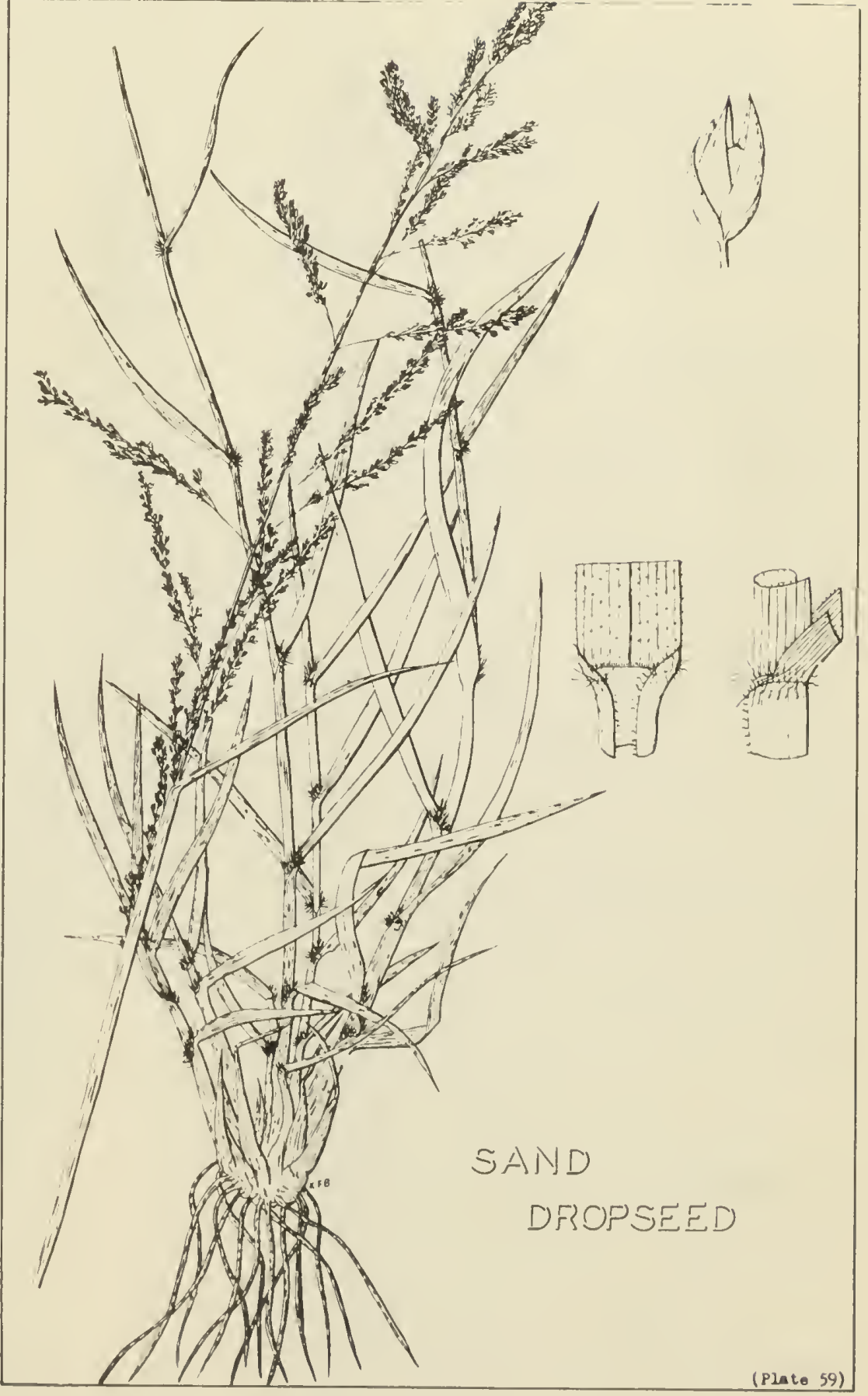

character of the seed is its long life. Experiments show a high viability even after 20 years of storage. 


\section{SPEAR GRASS}

Stipa comata Trin. and Rupr.

Spear grasses or needle grasses have a world-wide distribution. Most are excellent forages, but a few have sharp pointed seeds which cause mechanical injuries to livestock while one is known to be poisonous. Six needle grasses occur in the Prairie Area.

Spear grass or needle-and-thread is a long-lived perennial which occurs throughout Ilestern Canada and extends southward through the United States into Mexico. It is one of the most important native grasses in the Prairie Area, although its stands become progressively sparser from the dry central portion where it produces nearly 50 per cent of the pasturage to the Parkland where it is quite rare.

Spear grass is a bunch grass with a root system extending about 3 feet beneath the surface. Its gray-green leaves grow in a dense cluster. One to ten straw-colored stems are prostrate at the base and grow to a height of 2 feet. The panicles are loosely spreading and branched. Each branch carries several one-flowered spikelets. The seed hull is round, straw-colored, about $1 / 2$ inch in length, and ends in a twisted bent awn from 3 to 4 inches long. A sharp needle-point callus occurs at the lower end of the seed.

Spear grass is probably the most palatable of all native grasses. Its leaves start growth in late April and grow rapidly until mid-June, at which season the shotblade emerges. Flowering commences in early July and seed is mature and dropped by early September. Protein contents of spring growth will be over 20 per cent but decrease to about 5 per cent when curing is completed. The species is drought tolerant and resistant to frost, but can be grazed out with heavy pasturing.

Recent studies have shown that the leaves are light in comparison to their length during the spring.

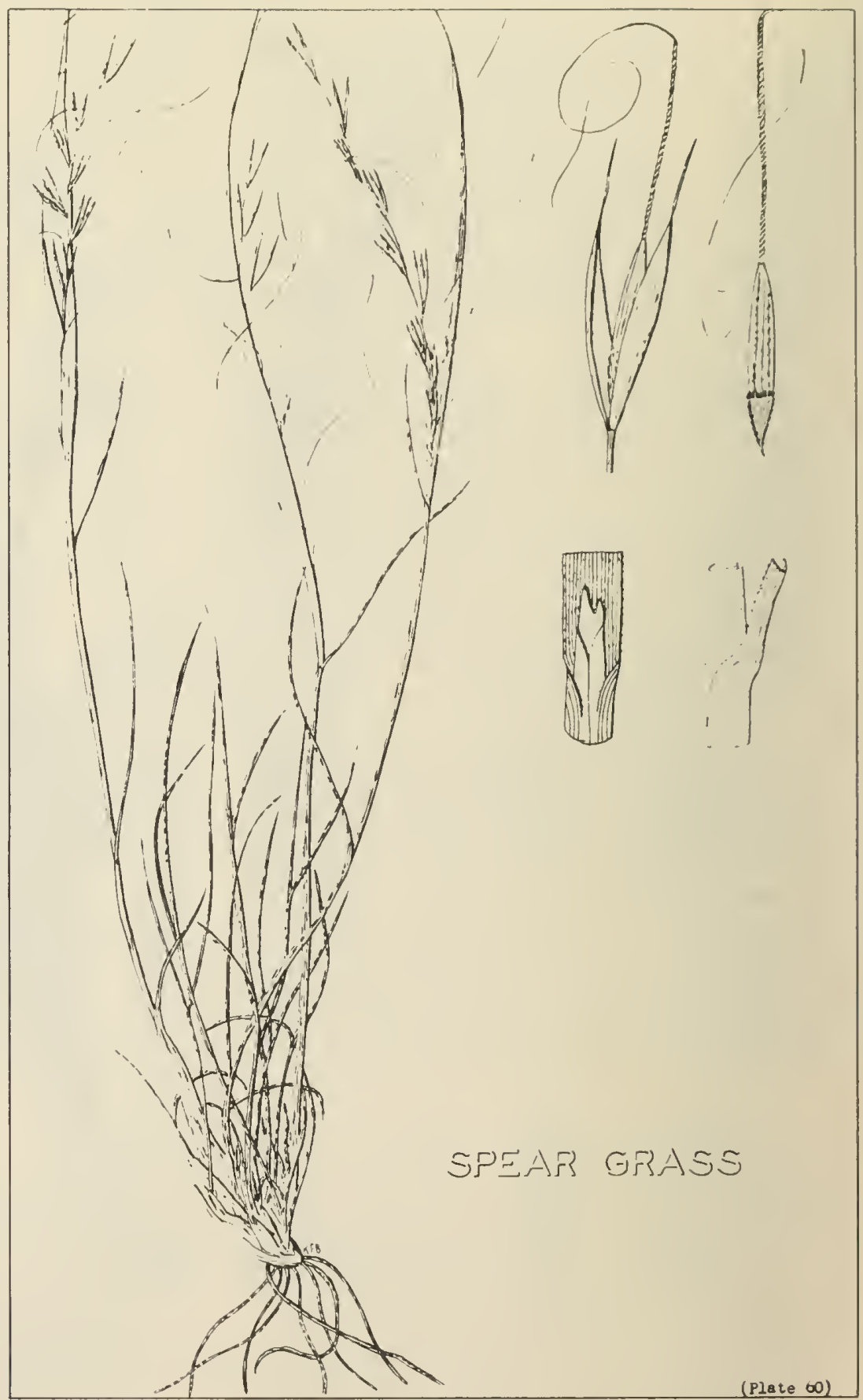

This has indicated the need for protecting spear grass pastures until mid-June. Other work has shown that a cow requires about 5,000 plants per day in order to satisfy her appetite. 
Stipa spartea Trin.

Porcupine grass is an eastern species, being locally abundant in Eastern Canada and the Northeastern United States. Within the Prairie Area, it is fairly common throughout western Manitoba with heavy stands occuring on sandy soils adjacent to the Assiniboine River in both Saskatchewan and Manitoba. Plants have been collected also throughout the Parkland region of the Prairie Provinces.

Porcupine grass is a robust bunch grass. Deep feeding roots form a dense mat near the surface and thus effectively control erosion on the sandy plains where the species makes its best growth. Many narrow leaves over 1 inch in length grow to form a very coarse forage. The whitish-colored stems which may be over 4 feet in height terminate in an open panicle which produces up to thirty or more seeds. The seeds are nearly an inch in length including the needle sharp tip. A long, twisted, twice bent awn grows from the upper end of the seed. Seeds calch on clothing, hair, fur, and wool after which the sharp callus easily penetrates the skin. Another distinctive character of the species is associated with the basal leafs sheaths - the old sheaths persist to form a very straggly crown.

Porcupine grass is poor feed. Even its early spring growth is coarse and not too palatable. From the time the seed head has emerged from the stem until the seed is dropped, no animal will willingly venture through a stand. After the seed drops off, some grazing may be obtained. In the few districts where porcupine grass is dominant, it is a common management practice to burn off the old growth, a treatment that does not injure old plants but does prevent the establishment of

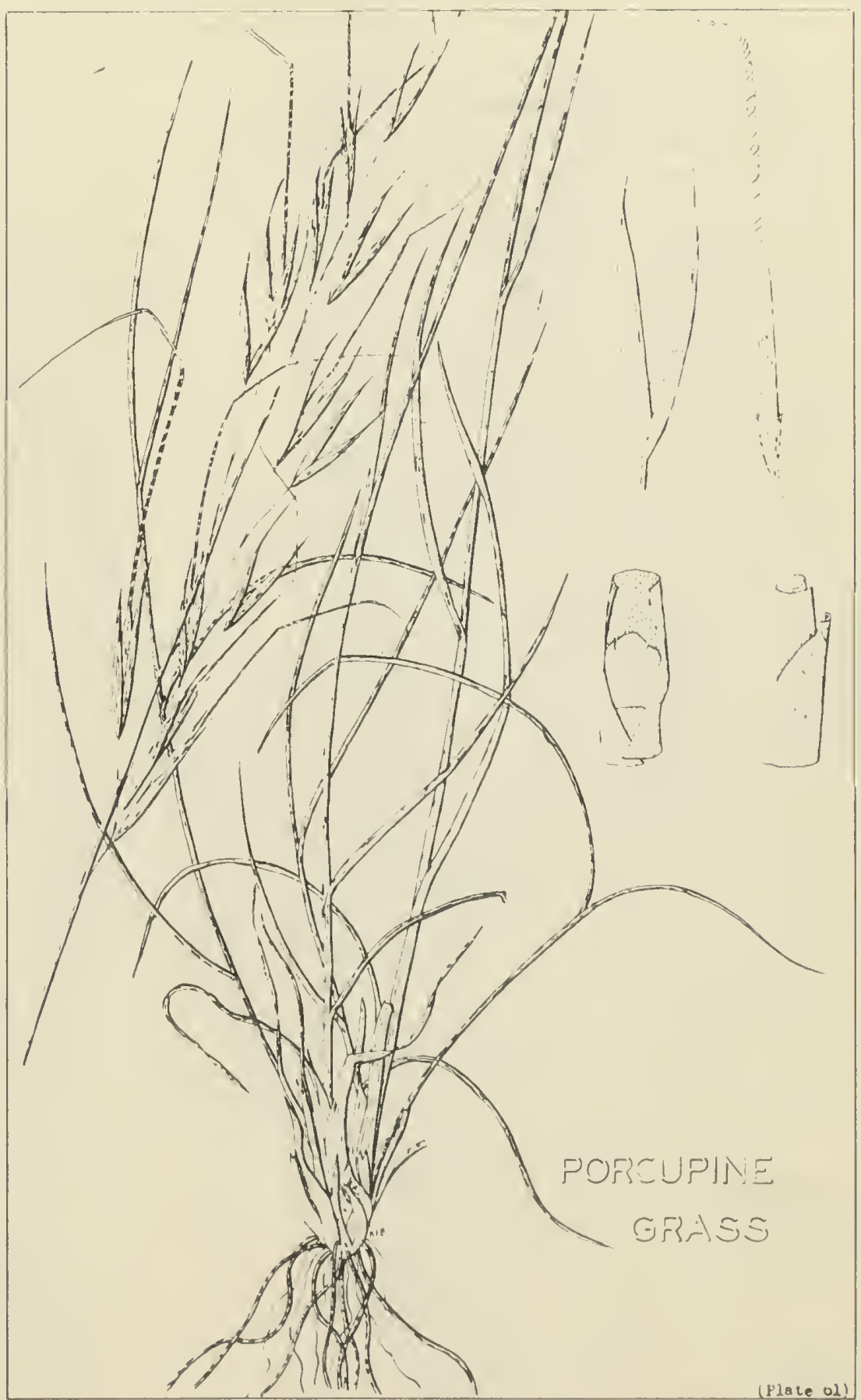

seedlings. The Prairie Irea is fortunate in that there are very few large stands of this grass. 
Stipa spartea Trin. var. curtiseta Hitchc.

Western porcupine grass is not a particularly good name because it looks more like the common spear grass than it does like the robust and harsh porcupine grass. In fact, its leafage is hard to distinguish from the former species, although its leaves are somewhat longer and pale green instead of the gray-green of common spear grass.

Western porcupine grass is usually the dominant species on loam soils in the central part of the Prairie Area. Whereas common spear grass is the dominant needle grass in the dry central area and porcupine grass may be the dominant needle grass in the Parkland, western porcupine grass is the most abundant needle grass in the area between these two extremes. It is found only in the Prairie Provinces and the States of Montana, Wyoming, and the Dakotas.

Western porcupine grass is a shortleaved bunch grass. Its roots extend to a depth of 3 feet. The flowering stems are about 3 feet tall and produce up to thirty sharp-pointed seeds in the feathery panicles. The seeds are about $1 / 2$ inch in length and terminate in a 3-inch awn which is twisted and bent. In undisturbed stands the old basal leaf sheaths cling to the crown as do those of porcupine grass.

Western porcupine grass is fairly palatable to all classes of livestock except during the period between emergence and dropping of the seed. This grass starts growth late in April, matures and drops its seed by mid-August, and is cured by September. In general its nutritive and curing properties are considered to be somewhat poorer than those of common spear grass, but it is rated much higher in these regards than porcupine grass. Its calcium-phosphorus

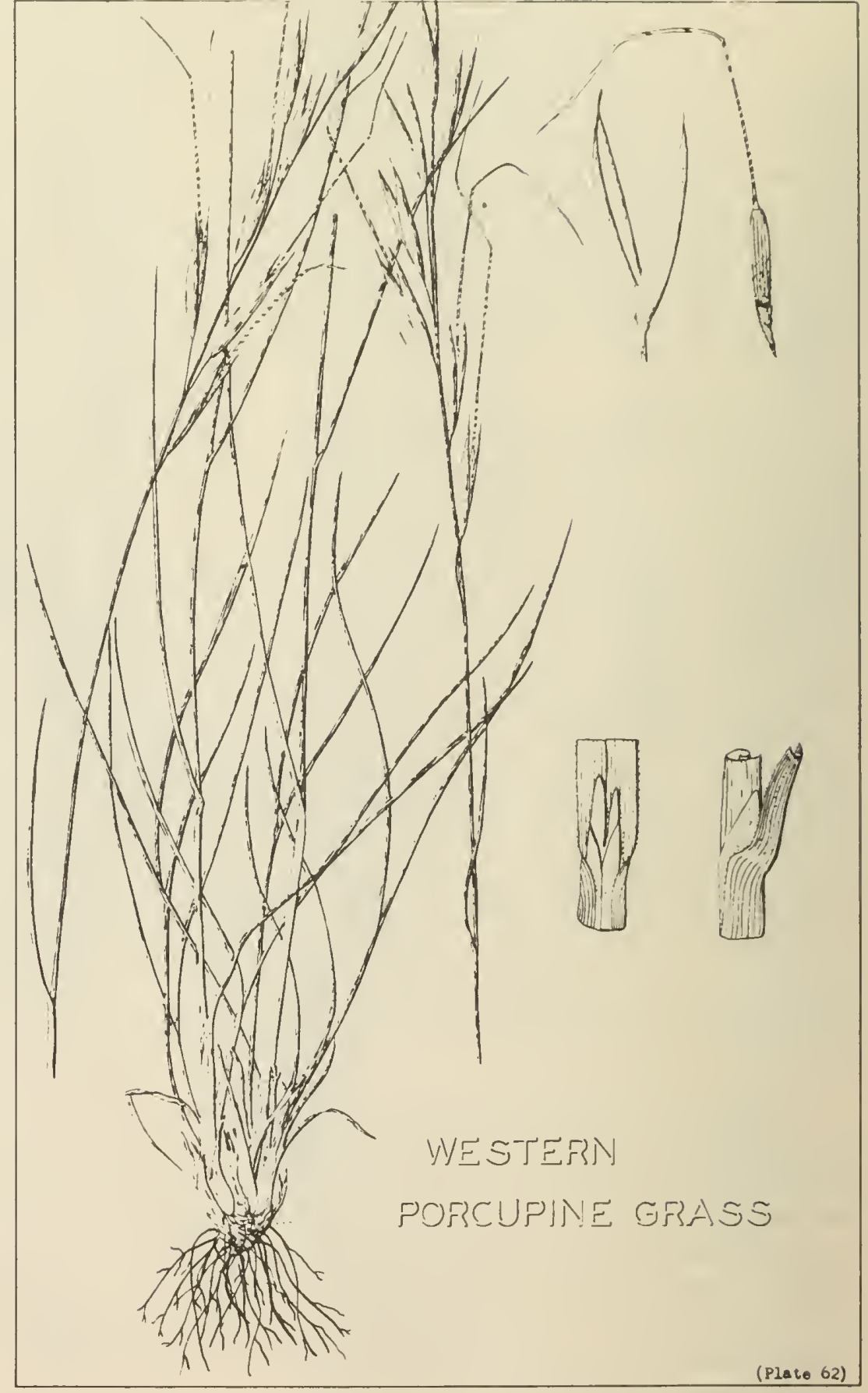

ratio after curing is approximately $5: 1$, about the same as for all good native grasses. 


\section{GREEN NEEDLE GRASS}

Stipa viridula Trin.

Green needle grass is known also as green feather grass. It is a grass of the Central Great Plains of North America, although there are a few records of its occurrence near the Atlantic seaboard. It is found everywhere in the Prairie Area, although few dense stands occur. Its best growth is made on heavy clay soils where it grows in association with bluejoint. Good growth is made also on sandy land if its deep feeding roots can reach a water table.

Green needle grass is a bunch grass with a dense root system which feeds down to a depth of 8 or 10 feet. Long, green, narrow basal leaves surround the 4 foot greenish-colored stems. Small black haircovered seeds are produced in abundance. There is no sharp pointed callus as in other needle grasses and the awn is weak and seldom over 2 inches in length. There are white hairs at the junction of the leaf blade and sheath and along the edges of the sheath.

Green needle grass is regarded as the most palatable of the needle grass group. It starts growth in late April, matures seed by mid-August, while curing is completed by mid-September. During these several stages of growth all livestock will seek this species and graze ịt readily. Spring protein contents will be over 20 per cent, and although some reduction of protein occurs as the plant matures, even late fall protein contents are often over 8 per cent. The ability to retain a relatively high protein content is one of the outstanding characters of this grass. In addition, it is drought and cold tolerant and moderately resistant to grazing.

An improvement program is under way to obtain a higher yielding strain. One of these selections known as green Stipa grass has been tested extensively in

Nestern Canada. On the basis of present information, it is expected that this grass will be a useful forage crop for the Prairie Area. 
Awned sedge is one of the principal plants which grow in non-alkaline shallow sloughs throughout the Prairie Area. In addition, it has a wide distribution beyond the region as it is found in similar sites in most of North America and throughout Northern Eurasia.

Awned sedge grows from strong rootstocks. Numerous three-angled leafy stems arise from these at relatively close intervals, in fact over 4.00 stems per square yard is not uncommon. Leaves are three-ranked and soft, with the underside covered by a dense mass of short hairs. Although the leaves hang down, if lifted to their full height, their tips may be more than 4 feet from the ground. The male flower head grows at the end of the stem and is dark brown and narrow. The female spike grows amongst the upper leaves; it is brown and thick when mature and each seed ends in a short awn.

Stands of the type described above will yield from 2 to 3 tons of palatable, nutritious, aromatic hay per acre. To obtain such yields the stands should be protected from grazing and the water supply needs to be sufficient to flood the stand until early July. However, awned sedge produces palatable pasture for cattle and sheep. Unfortunately, overgrazing reduces stands very quickly.

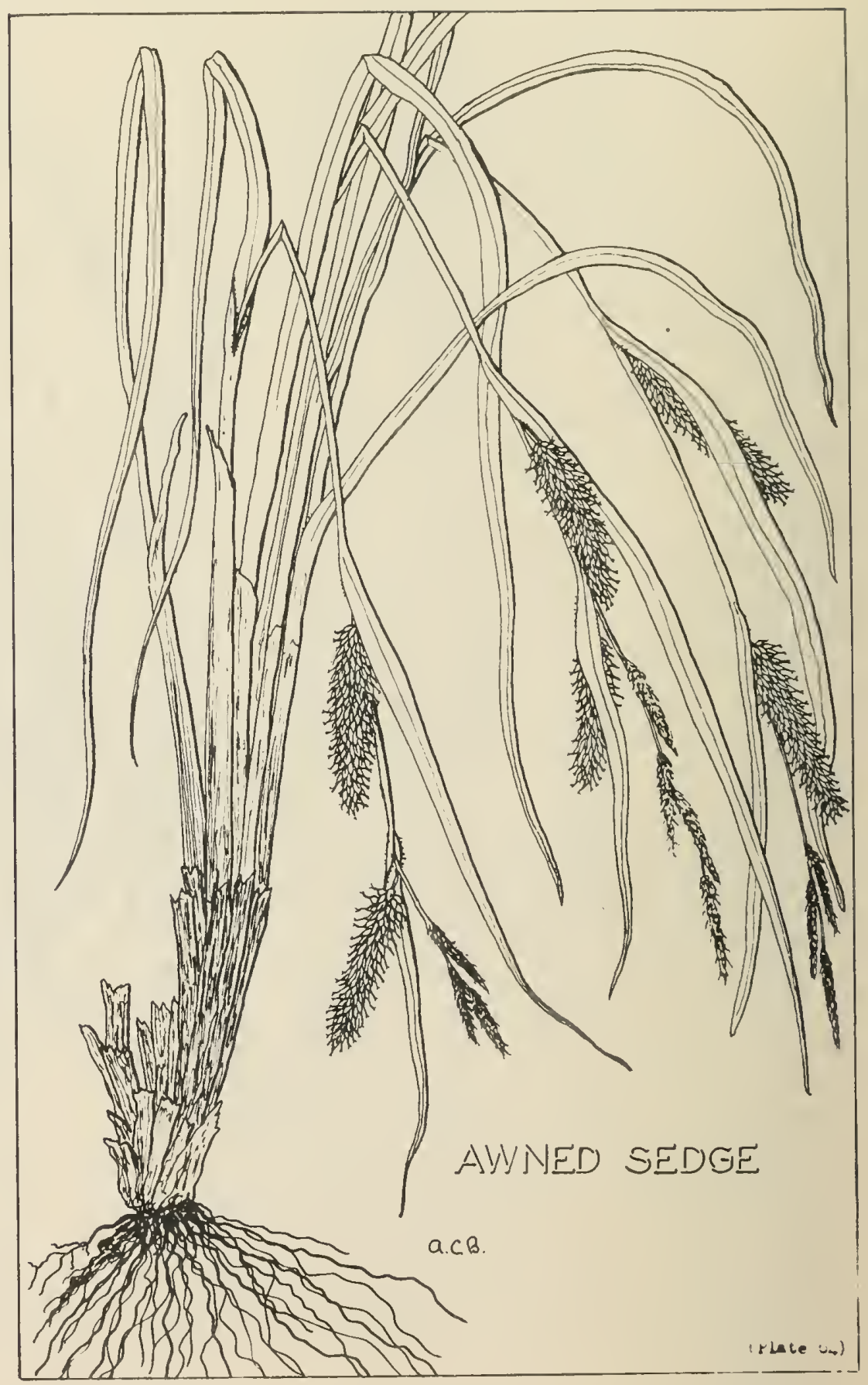




\section{LOW SEDGE}

Carex eleocharis Bailey

Low sedge is one of the most conmon dryland plants of the Great Plains Area of North America. Its range extends from Yukon to the Gulf of Mexico, and it may be found at elevations of 1000 to 7000 feet above sea level. It has been collected throughout the entire Prairie Area, with the heaviest stands occurring on overgrazed or eroded rangelands.

Low sedge is the smallest of the dryland sedges. A shallow rootstock sends up single planis at distances of 1 to 3 inches apart. These plants consist of a central three-angled seed stalk and either three or six leaves growing from the crown. The leaves are about $1 / 8$ inch in width and seldom more than 2 or 3 inches long. The single seed head per plant has male flowers at its tip and female flowers immediately below, while its total length is seldom more than $1 / 2$ inch. The seed matures early in June and the brown heads and drying leaves are distinctive at a season when grasses are green.

Heavy stands of low sedge indicate an overgrazed pasture. A casual observer nay confuse the brownish color in June with carryover of grasses. However, closer observation will differentiate between the brown color of maturing sedge and the gray-brown of carryover. Insofar as is known, low sedge is fairly palatable, but its low growth and poor yield and the fact that it spreads as overgrazing progresses makes it little better than a pasture weed. Where it becomes dominant, stockmen are advised to cultivate the pasture and reseed with grasses recommended for the district.

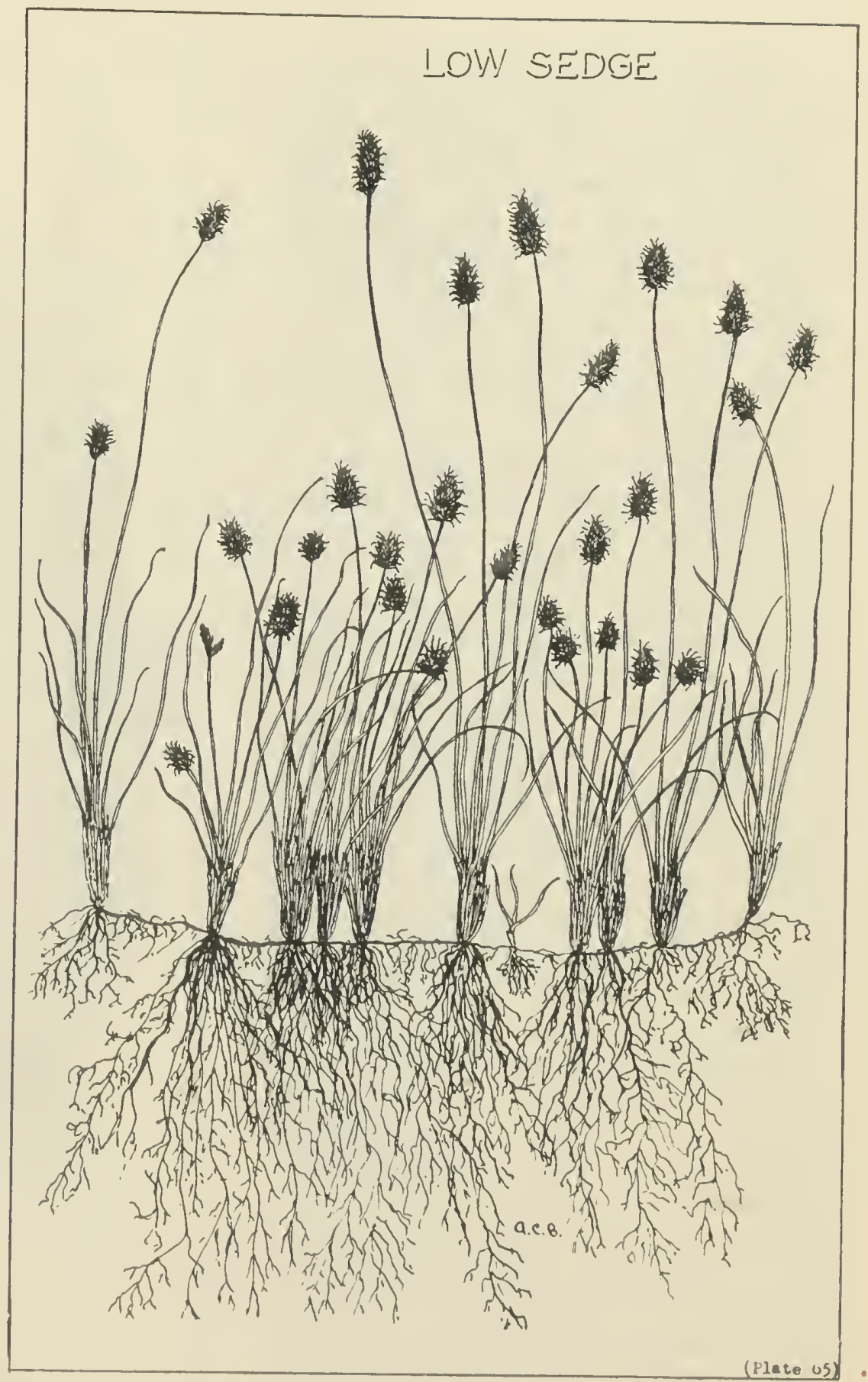

Two other small dryland sedges are

often confused with low sedge and both may occur with it. Sun-loving sedge, C. heliophila llack, has wider, glossier, and more numerous leaves and it usually has more than one flower cluster on its seed bearing stem.

Blunt sedge, $C$. obtusata Liljebl., is very similar to sunloving sedge except that its seeds are nearly black in color when mature. Neither of these sedges produces nuch forage, although both are apparently palatable. 


\section{THREAD-LEAVED SEDGE}

Carex filifolia Nutt.

Thread-leaved sedge, niggerwool, or hair sedge is a short growing, dryland member of the sedge family. Its distribution includes all of Western North America from the Yukon to California and throughout the Northern Great Plains. It is more common in dry regions than where moisture is abundant. Its heaviest stands occur on sandy flats, exposed gravelly ridges, and at other sites where the soil may be shallow or infertile.

Thread-leaved sedge is easily recognized by its fine, thread-like, upright, deep green, rolled, glossy leaves which may attain a length of 6 inches. Plants develop dense clumps, so dense that an observer would call the several small plants a single bunch grass; this character is caused by the numerous crowded shoots growing from the rootstock. Male and female flowers grow in the one head, with the male growing at the tip of the spike and the female at the base. The spike is oval-shaped, located at the extreme tip of a stem, and shiny after the seeds have ripened. A sure character to to identify thread-leaved sedge is the chestnut brown dead leafage which surrounds the base of the leaves.

Thread-leaved sedge is one of the most common plants growing in the shortgrass and mixed-grass regions of the Prairie Area. In a few districts it is dominant, but generally occurs as a sub-dominant with blue grama grass, common spear grass, and June grass. It is usually more palatable than the associated grasses, while chemical analyses suggest higher protein and phosphorus and much lower crude fiber contents.

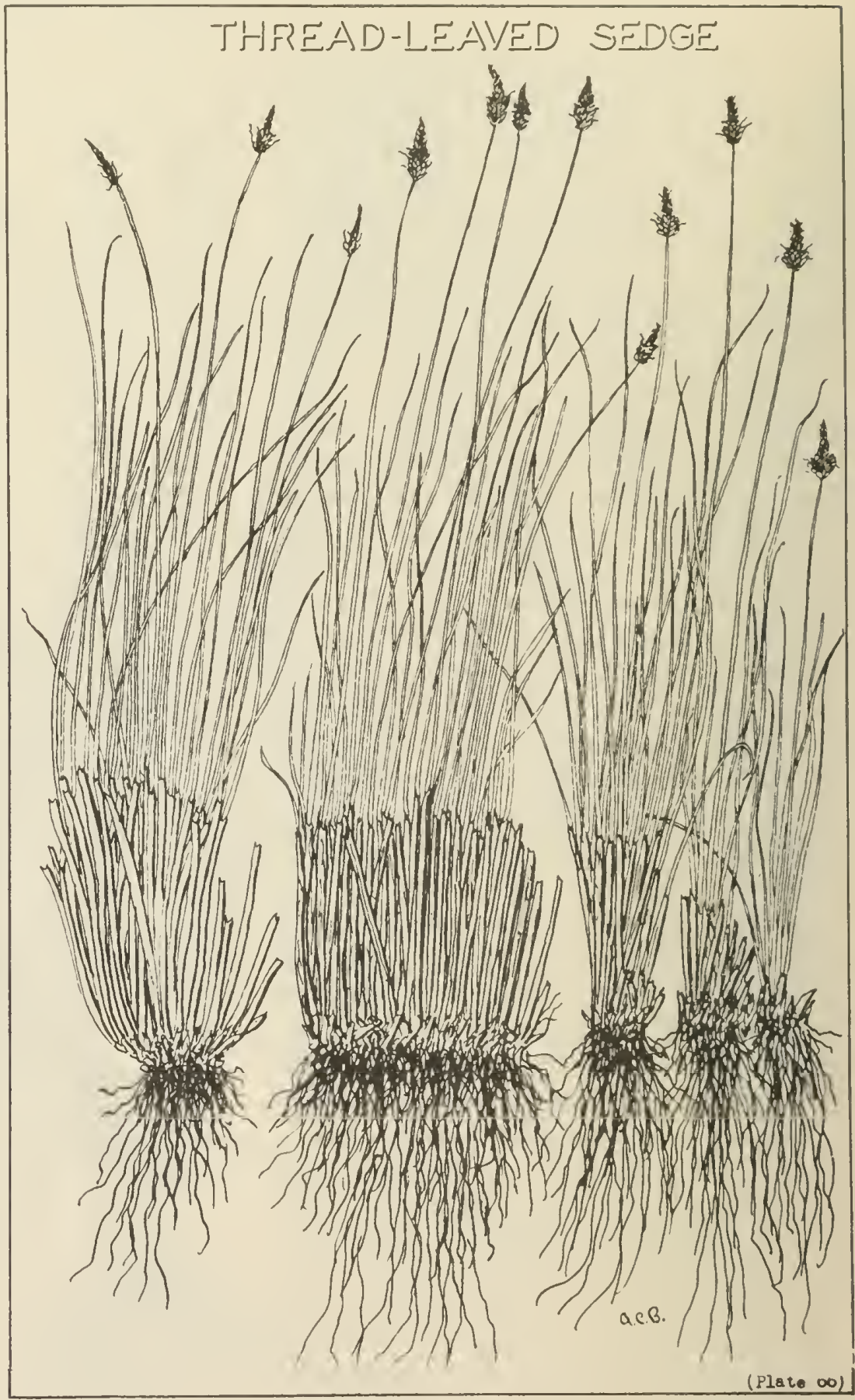
Its numerous fine, tough, black roots fill the soil to a depth of 3 feet and thus the species provides excellent protection against soil erosion. It withstands grazing better than the grasses with which

it grows and, although trampling may tear the plant into two or many parts, this severe treatment seldom affects its future growth. 
Beaked sedge is a close relative of awned sedge, in fact only small visible differences differrentiate these species. They grow under the same conditions, the stands yield similar tonnages per acre, their boundaries of growth are similar, their reactions to grazing and hay production are alike, and they grow together in mixed stands. From a practical viewpoint they are identical, from a botanical viewpoint there are interesting differences.

Beaked sedge grows from strong creeping rootstocks. Its soft leaves grow in whorls of three and are entirely free of of hairs. The male spike grows near the tip of the robust three-angled stems, while the thick female spike grows amongst the leaves. An important difference between awned and beaked sedge occurs in the female spikes, as the seeds of beaked sedge end in a distinct curved beak.

Dairy cattle milk heavily on beaked sedge hay and beef cattle will eat it readily. However, hay which grows in water will be light and should be supplemented with grain to obtain full utilization of its nutrients. Its protein and phosphorus contents are high and its crude fiber content low. Harvest before the end of July to obtain good quality feed.

A similar appearing species, water sedge, $C$. aquatilis Wahl., grows in brackish or saline springs and marshes. It has fewer and narrower leaves and the base of its stem is reddish. It is not palatable and seldom if ever grazed.

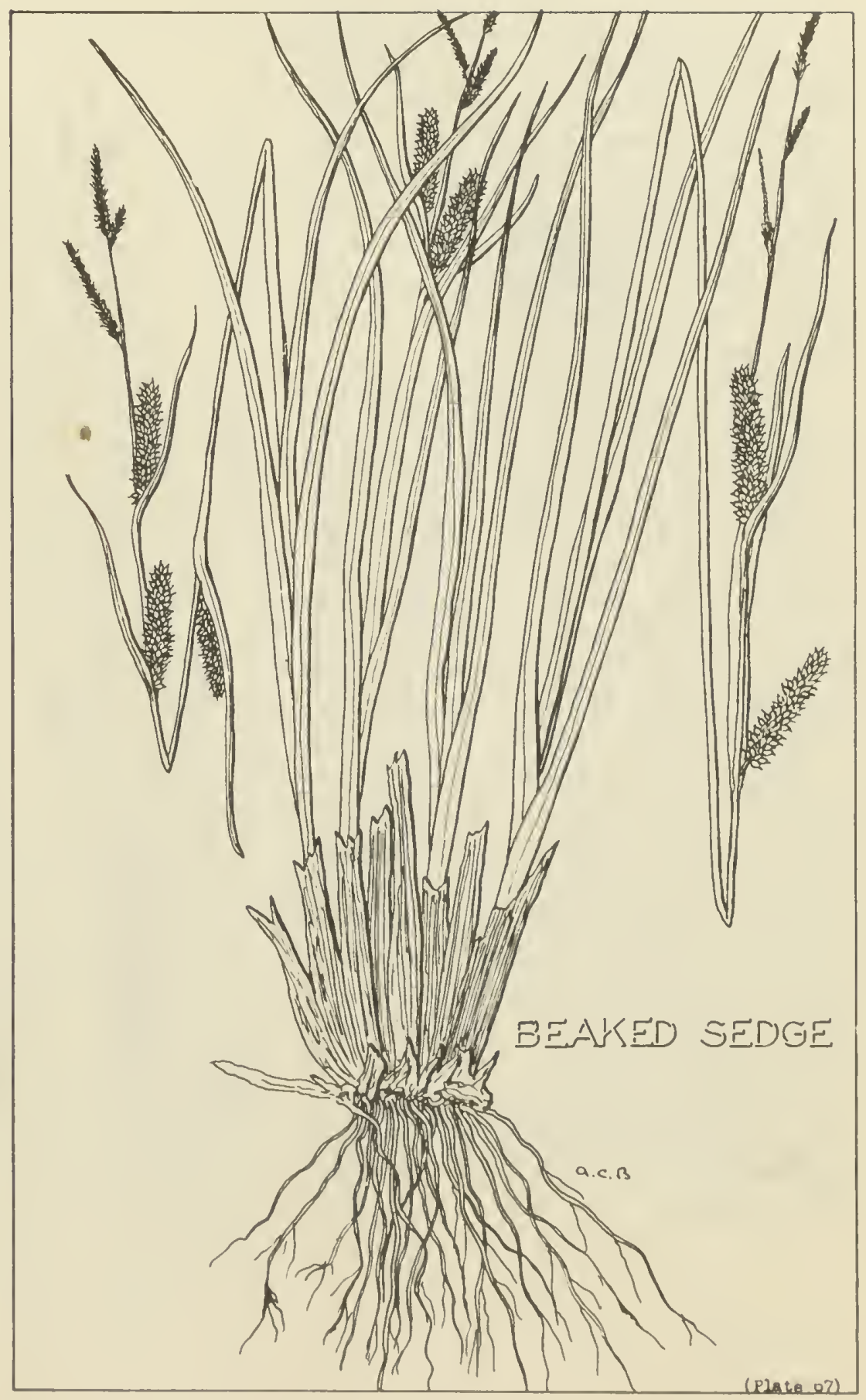


Spike rush is another common member of the Cyperaceae family. It inhabits the muddy, moist shores of marshes and grows profusely in shallow sloughs throughout the southern portion of the Prairie Area. In addition, it will persist in areas of considerable alkalinity provided its moisture requirements are satisfied. It has a wide distribution throughout Canada, the United States, and Eurasia.

This is a perennial plant growing from a creeping rootstock. Its numerous tough roots fill the soil and send up tufts of stems at close intervals to height of 16 inches. The stems are round or oval and are filled with pith. A few short leaves may develop around the base, but the rounded stem is the prominent feature of the plant. Each floret is complete in that it contains both male and female organs. The seeds are yellowish-brown and shiny.

Spike rush is palatable to horses, so palatable in fact that they will wade into sloughs to graze it during nearly all stages of its growth. Cattle eat it readily but less avidly than horses. During the spring and summer, it will have high protein, phosphorus, and carbohydrate contents and be low in fiber and fat. It does not make good hay, as its palatability seems to disappear with the drying of the slough. It can be fed as an emergency winter roughage, but should be supplemented with both grain and better quality hay.

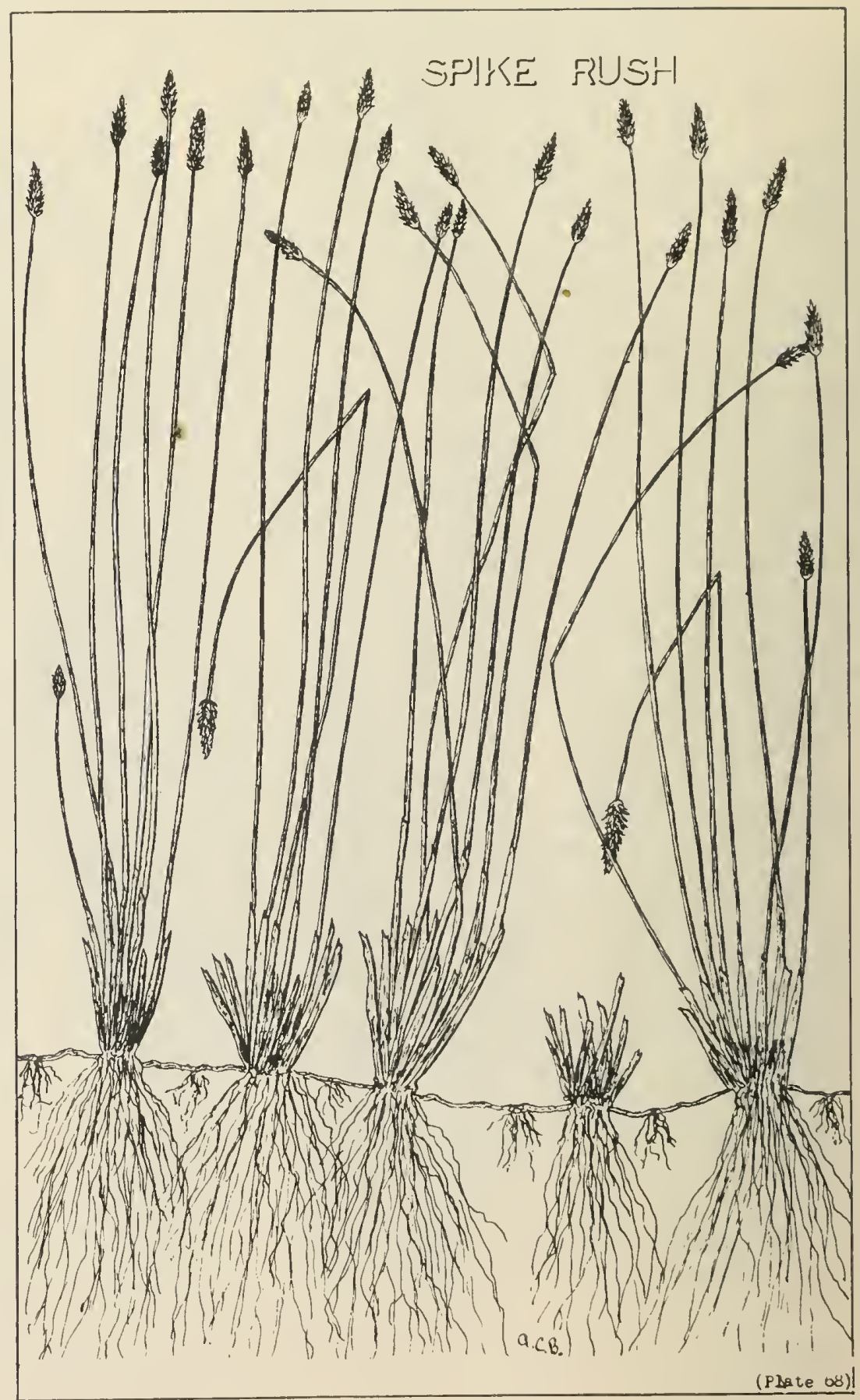


Baltic rush is so called because of its prevalence along the shores of the Baltic Sea. However, it has a widespread habitat, being found throughout Europe, Asia, and North Anerica. Dense stands seldom occur in the Prairie Area, but it is prevalent on all soils with a high water table, while sparse stands occur on nearly all sandy land. Because of the toughness of its stem, it is also known as wire rush.

Baltic ruslı has strongly developed, dark brown rootstocks, as well as an extensive and deeply penetrating fibrous root system. Numerous stens rise from the rootstocks, each terminating in a nodding flower cluster. A long bract or leaf continues from the stem above the flower head. Small scaly leaves surround the stems at their base.

At sites where soil moisture is available throughout the summer, Baltic rush will maintain a continuous growtl. While green and in sparse stands nixed with grass, it is eaten readily and if cut early enough and properly cured it makes a palatable but light component of native hay. However, it loses palatability when it dries out or after frosts. It has a higher protein content than many range grasses, while its fiber content is relatively low. Because its extensive rootsystem is an efficient soil binder, it is an excellent plant for erosion control. Children of pioneer settlers used the wiry stems to make "daisy chains", while some Indian tribes used the stems to make baskets and mats.

Although Baltic rush is the most common of the Juncus family growing in the Prairie Area, plant lists slow that seventeen different species occur. Toad rush, J.bufoni's L., grows everywhere around saline lake margins, while the tall growing Dudley's rush, J. dudlevi Wieg., is

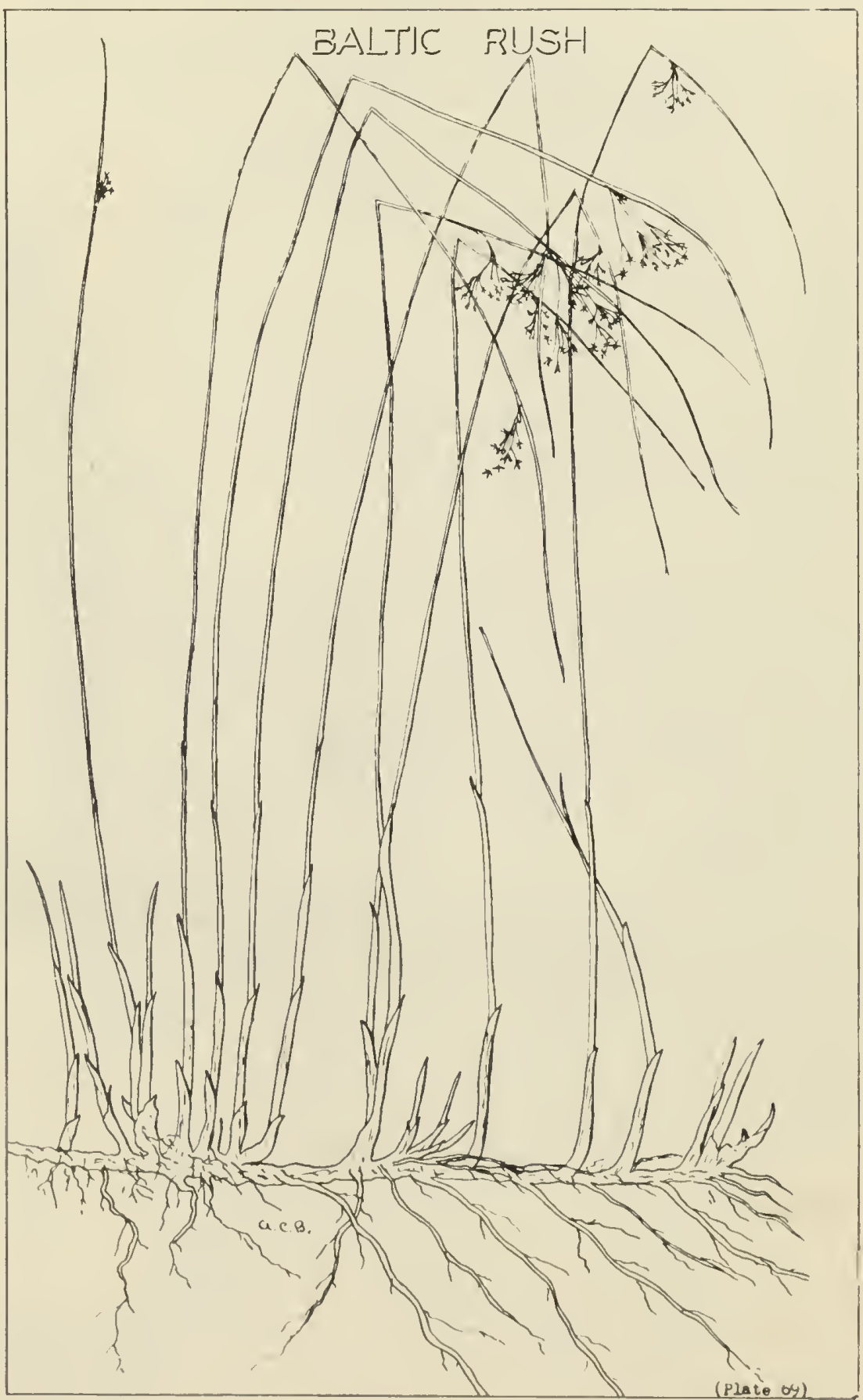

common in sloughs where a constant water level of about 2 feet is maintained. In general, species of this family have low palatability ratings. 


\section{STAR-FLOWERED SOLOMON'S SEAL}

Smilacina stellata (L.) Desf.

Star-flowered Solomon's seal is a member of the lily-of-the-valley family and is the most common of the fifteen representatives of that family occurring in the Prairie Area. It is distributed across Canada and from the Boreal Forest southward as far as Virginia and Colorado. It seldom occurs in dense stands but rather as spaced plants amongst the associated grasses. Although it may be found in relatively dry areas, its occurrence is more common in moist meadows and around groves of trees. It is known also as three-flowered Solomon's seal and wild spikenard.

Smooth, light green stems, 1 foot or more in height, grow from white rootstocks. From six to ten smooth leaves up to 5 inches in length grow on opposite sides of the stem, but not in pairs. Small, delicate, white, star-shaped flowers grow at the summit of the stem. Greenish berries with dark stripes in the immature stage turn black at maturity.

Very little is known about the usefulness of this plant except that it is grazed readily by all classes of livestock. Its early spring growth is particularly attractive to sheep and cattle, and even when cured sheep have been observed grazing its dry leaves. However, because of its open stand, it does not add much to the forage supply.

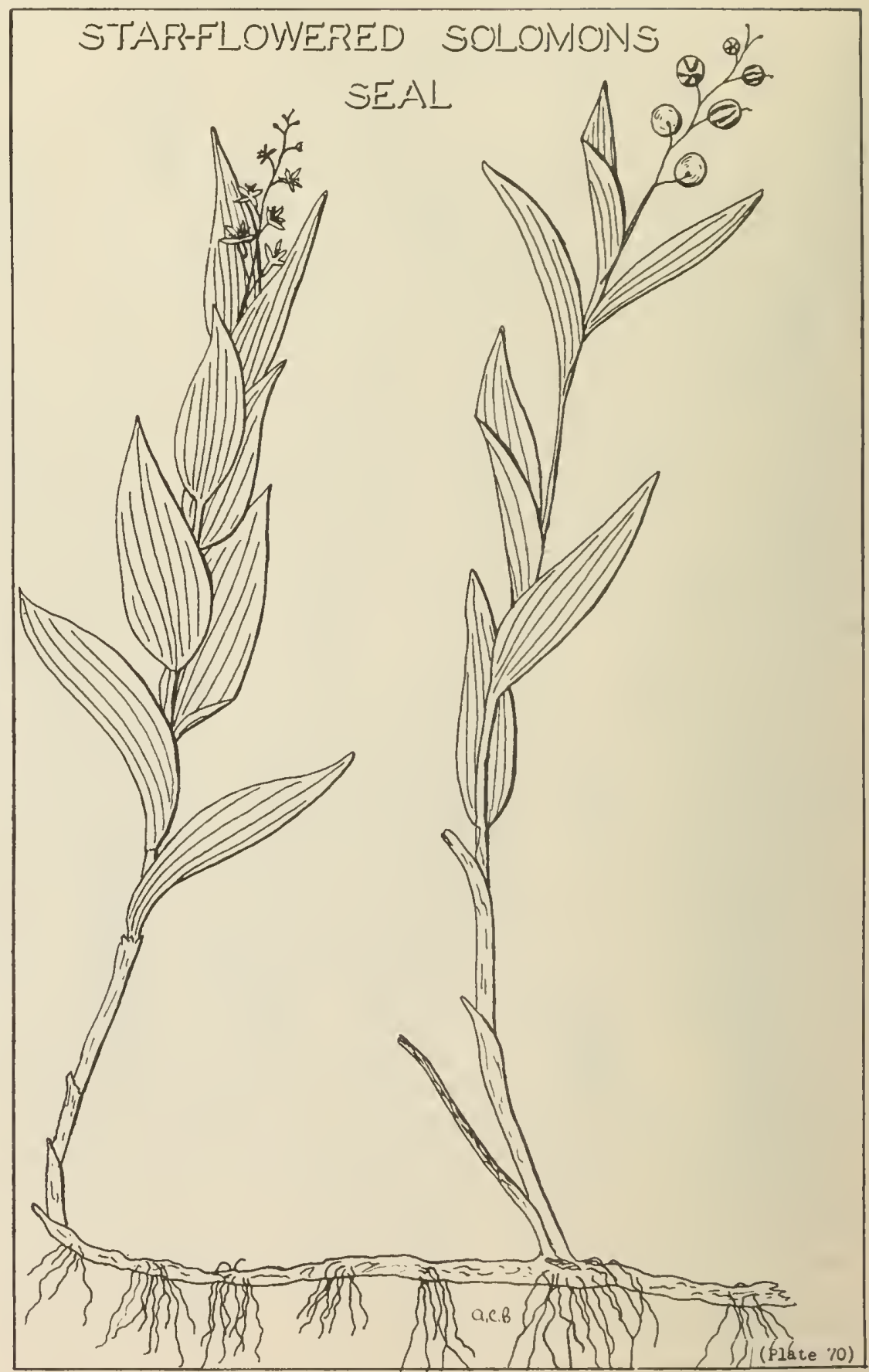


Aspen poplar is the most common tree throughout the Prairie Area. It has a wide range as it is found from Newfoundland to Alaska, and southward as far as Tennessee in the east and New Mexico in the west. During the past fifty years it has increased its stand in the Parkland and has spread southward into the drier portions of Alberta and Saskatchewan. It has many local names including trembling or quaking poplar, trembling aspen, and popple, all referring to the trembling motion of the leaves in very light breezes.

Aspen poplar is a forest-forming tree, although it grows also in open stands. Its smooth whitish or greenish bark covers most of the trunk, but rough black bark may cover the first few feet with black spots becoming smaller and fewer upward. The leaf stalks are flattened and bear smooth toothed leaves which are from 1 to 3 inches in width. The male and female flowers, which are on different trees, appear before the leaves in the form of pendulous catkins. This species reproduces stronglyby root shoots, but heavy grazing tends to slow this development.

Nearly all classes of livestock including game will graze aspen during all seasons of the year, but seldom heavily enough to check its spread. Leaves as well as young twigs will be eaten readily. Chemical analyses of these indicate high protein and phosphorus and extremely low crude fiber contents - all characteristics of good forage.

As aspen grows on nearly all soil types where climate is favorable, its presence is not a good indicator of soil quality. However, on poor soil its growth is slow and spindly, and its associates will be range weeds. On fertile soils it develops open stands with individual trees up to 60 feet in height; where these conditions

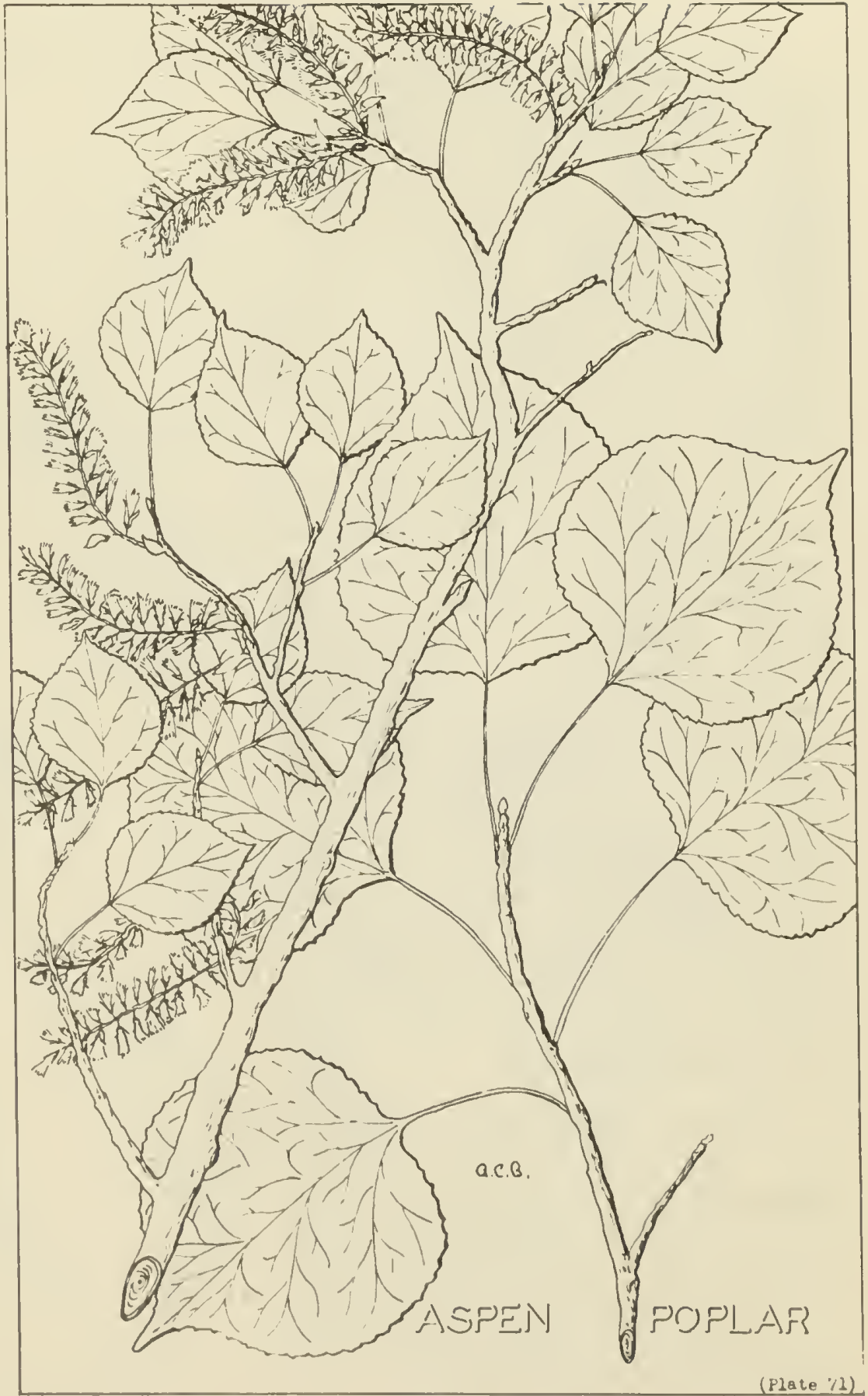

occur the aspen grows in association with palatable and nutritious grasses and forbs, a combination which makes excellent pasturage. 


\section{WILLOW}

Salix spp.

The willow group contains many different species, most of which are extremely difficult to identify. They have a wide range also, growing on moist slopes and flats, along river banks, and in mountain meadows throughout the northern hemisphere. They may be very small slender shrubs or large trees suitable for lumber. Studies of the willows growing in the Prairie Area indicate that there are over fifty different species, all shrubs or small gnarled trees.

Willow and poplar have many characters in common and in some instances are hard to distinguish. However, Prairie Area poplars are trees, while willows are shrubs. Poplars usually have a long leaf stem whereas willow leaves have short stems or none. The buds of poplars are covered with several sticky scales. but the buds of the willow have a single shiny scale whose color is usually dark brown. Poplar leaves usually have saw-toothed edges, while willow leaves will have smooth or only finely serrated edges. As with the poplar, willows have male and female flowers on separate trees and in most cases the catkins appear before the leaves. A few species have creeping rootstocks.

Willows are good browse. Sheep and deer eat the leaves and twigs more readily than cattle, but cattle probably utilize them to a greater extent because of their grazing habits. Chemical analyses show that all willows have higher protein and phosphorus conients than grasses and the young growth is lower in crude fiber.

Because willows grow only in moist locations, they will not snread into dry grassland as will the aspen. In fact, as heavy grazing reduces the grass cover, there is usually a reduction also in the willow population caused by both tramping

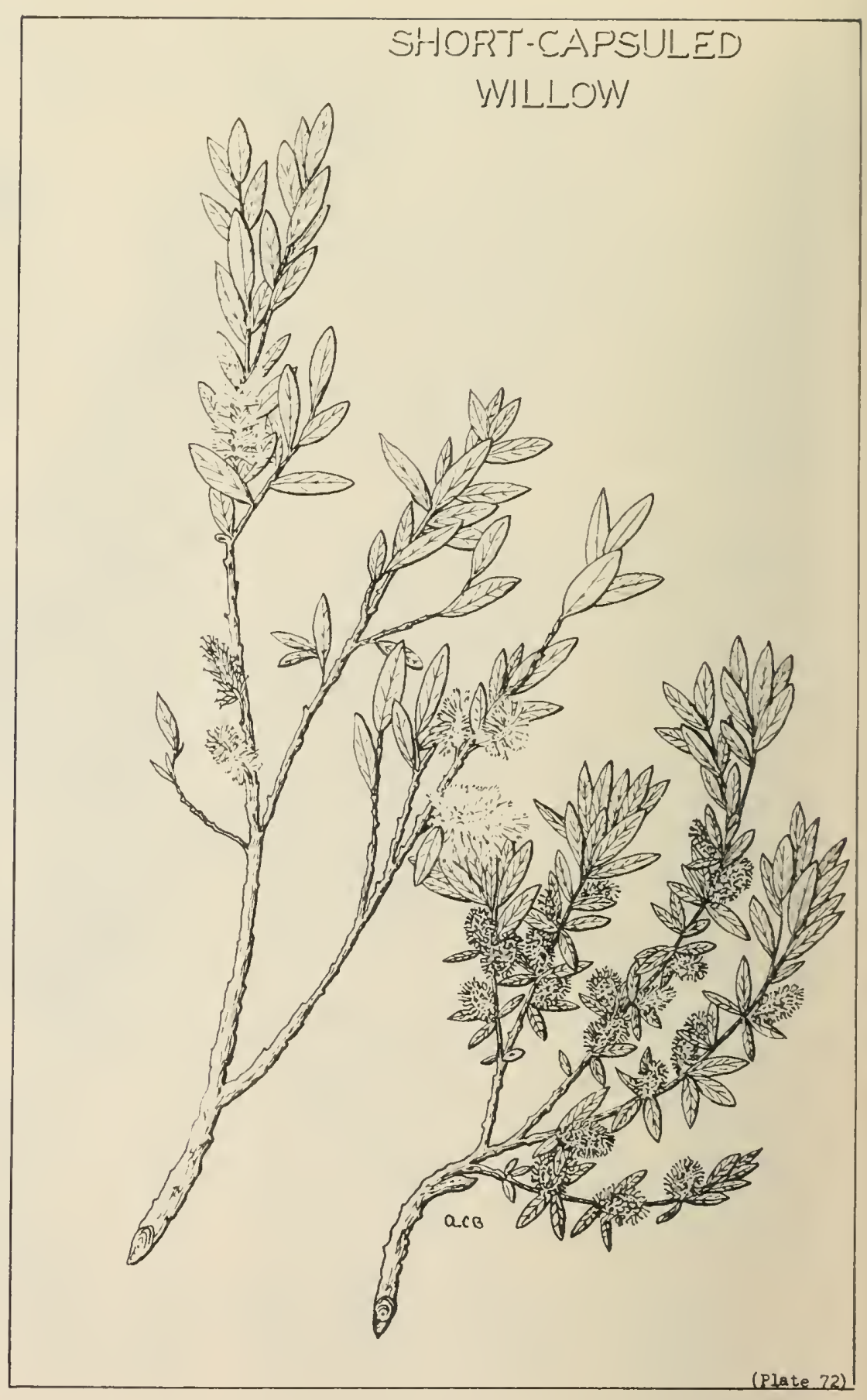

and grazing. Thus the disappearance of willow, and particularly the broad-leaved shrubby types, may be an indication that overgrazing is occuring. 


\section{RIVER BIRCH}

Betula occidentalis Hook.

River birch is the most common birch growing in the Prairie Area. It occurs on moist flats along river banks and in moist sandy flats from Nanitoba to the west coast and from Yukon to California. In the Prairie Area its heaviest stands are found within the Great Sand Hills in western Saskatchewan. It has many common local names including mountain birch, water birch, swamp birch, and black birch. River birch occurs either as a short tree or as a tall dense shrub. Its dark brown aromatic and resinous bark is dotted with gray-colored lenticels. The leaves are seldom over 2 inches long and the edges have a double serration, that is, the teeth appear to be in pairs with one larger than the other. As with other birch species, it has separate male and female flowers, but both grow on the same tree. The fruit is a small nut enclosed by a scale in a small cone.

Birches generally are not good browse, in fact they will be eaten only by very hungry animals. However, ranchers from the Great Sand Hills report that cattle will break off the branches to reach the young stems during the winter and early spring.

There are a few other species of birch occuring within the Prairie Area. Low birch, B. glandulifera (Regel) Butler, is quite common in acid soils in mountain and northern swamps, while paper birch, $B$. papyrifera Marsh., and yellow birch, $B$. lutea Michx., are not rare in the eastern part of the region. A closely related group, the alders, resembles the birches and may beconfused. Characters which help to seperate these groups include the smoother

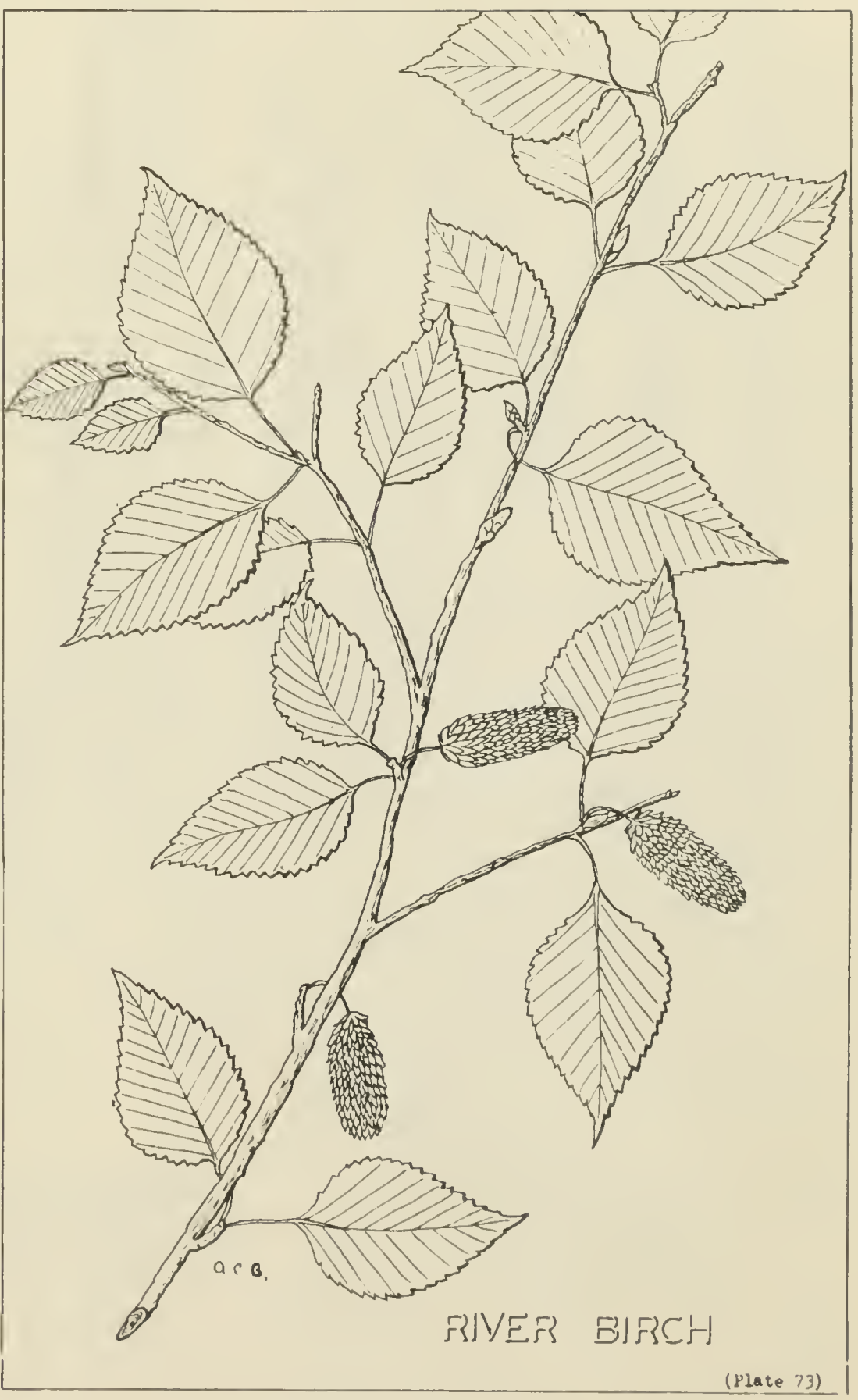
bark and the rounder leaves of the alder. Birches and alders are poor forage plants. 


\section{SMARTWEEDS}

Persicaria spp.

Smartweeds are members of the buckwheat family that grow in shallow water or along the margins of non-saline sloughs throughout the northern hemisphere from the Equator to the Arctic Circle. In the Prairie Area they dominate the vegetation in sloughs which contain less than 2 feet of water in the spring and which will be dry by midJuly. The common co-dominants will be awned and beaked sedge. Smartweeds are known also as Lady's Thumb (because of the darker leaf center, water pepper, and persicaria. Both annual and perennial forms are known. The same species may grow on land or in water.

The spike-like cluster of small white or pink flowers is surrounded by leaves which are long, oval or lance-shaped, and with a darker green center. Most aquatic forms are hairless, but the leaves and stems of those growing on land are usually very hairy. The stems have nodes or joints similar to grasses; these are enclosed by small membranous or leafy sheaths.

The smartweeds which grow in water and which can be harvested as sloughs dry up make excellent aromatic hay, but those which have developed entirely on dry land are harsh and unpalatable. Leafy and green smartweed hay will contain 15 per cent or more protein with corresponding low levels of crude fiber. In combination with the sedges or water fescue, smartweeds make palatable and nutritious but light hay. Smartweed is less attractive for pasture and will be seldom grazed. This latter fact is important because smartweeds which are pastured are credited with causing "yellows" or bighead" in livestock with white skins; the

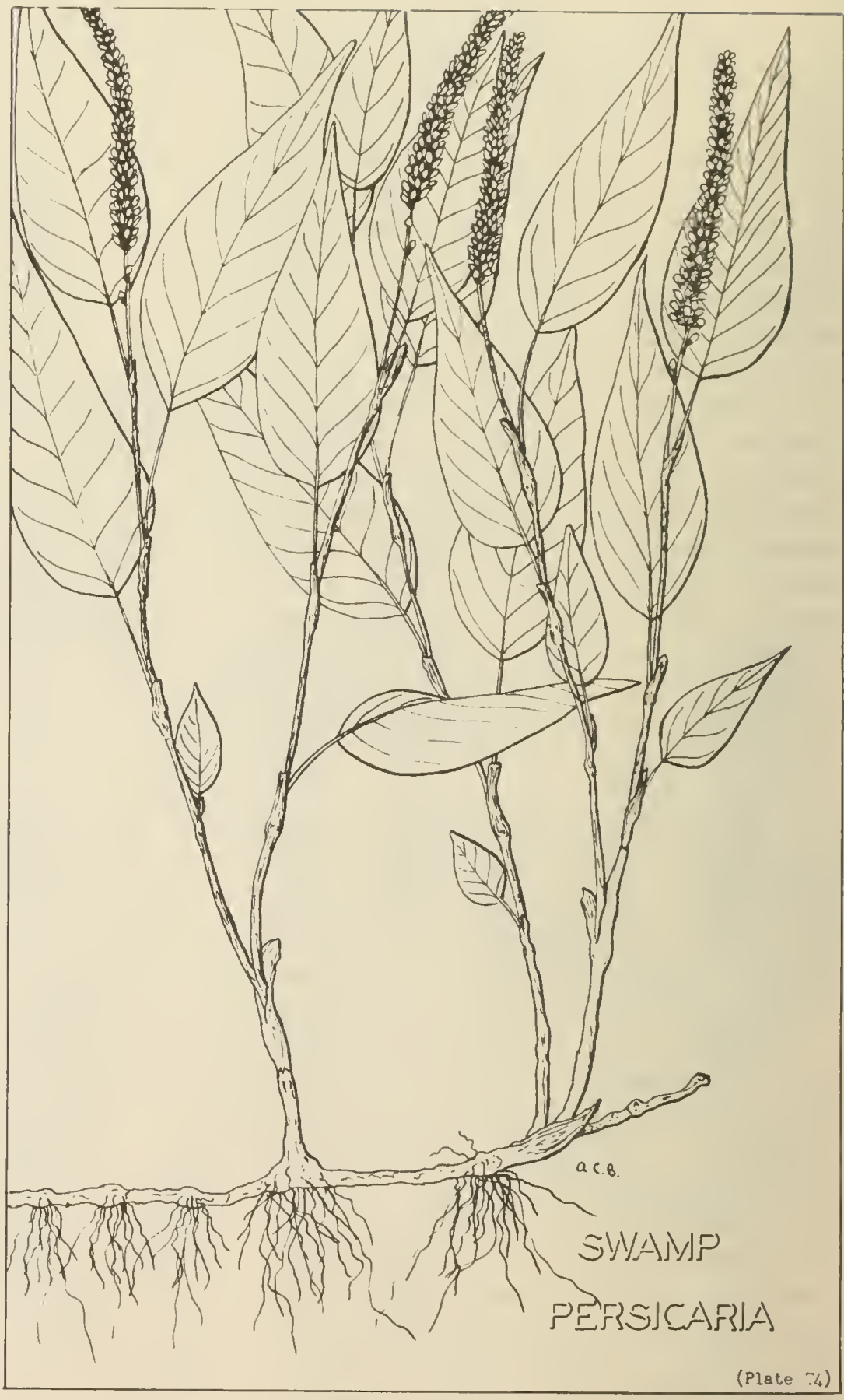
condition is seldom if ever produced when fed in well- cured hay. 
Atriplex Nuttallii S. Wats.

Nuttall's atriplex is a member of the goosefoot family whose center of population is in the southern parts of Alberta and Saskatchewan, though it extends southward through Colorado and Nevada. It grows well on moderately saline soils in association with bluejoint and on shallow soils dominated by blue grama grass.

Nuttall's atriplex is a low-growing perennial shrub whose branches seldom attain a height of more than 1 foot. The leaves are usually alternate, long oval, without stems, pale green, and scurfy. The yellowish male flowers grow on one plant and at the end of the branches, while the female flowers are on other plants and are usually surrounded with leaves. Its deep root system assures its protection against drought, although new stems grow slowly after being grazed or destroyed by dry conditions.

The palatability rating of Nuttall's atriplex is high for all classes of livestock despite its unappetizing appearance. Although it will be grazed at any season, reports indicate that it is preferred in the autunm and winter. Chemical analyses show protein contents of over 10 per cent in late autumn, while phosphorus contents will be nearly twice as great as for the cured grasses. As with many other shrubs its crude fiber content is low, while that of ash will be high.

Members of the A triplex group are found throughout the temperate and tropical portions of the world. They are the dominant shrubs in the deserts of Australia and in many of the salt flats throughout the Western United States. They are rated as good to excellent forage plants wherever they grow, but require

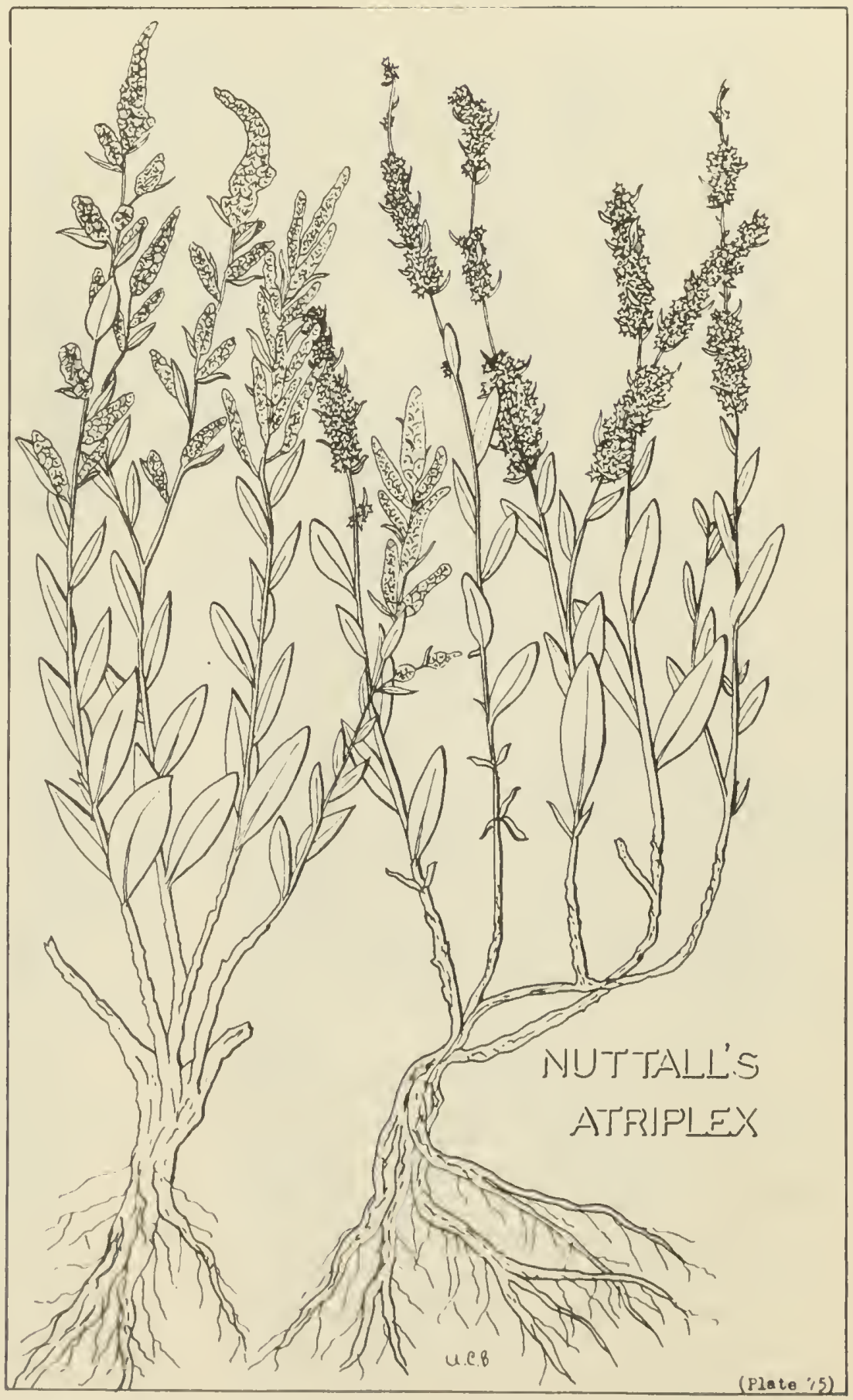

careful management to maintain their productivity. 
Winter-fat or white sage is a member of the goosefoot family whose range coincides closely with the semi-arid area of Nestern North America. Both of its scientific names are derived from Latin words, Eurotia referring to the white hairy herbage and lanata to the dense woolly growth covering the leaves. It grows on all welldrained soils, but may occur on shallow eroded sites as well as on soils containing considerable alkali.

Winter-fat is a low growing shrub seldom more than 18 inches tall. Numerous branches grow from the woody base, each of which produces many linear leaves. The male and female flowers are separate, with the male growing above the female. Its ash-gray color and hairiness are its most distinguishing features during the summer.

The palatability rating of winter-fat is very high for all classes of domestic livestock and game. Its nutritive content is in good balance, with protein and phosphorus being exceptionally high even in late fall. The deeply penetrating root system assures a moisture and food supply at all times. Its rapid recovery after drought is a feature of of its growth.

Unfortunately, winter-fat can be grazed out and has been on many range areas in the Western United States. The palatability of all parts of the plant and its susceptibility to damage by tramping are reasons why it disappears from the cover. However, it can be maintained in a productive condition if the associated grasses are managed to maintain a carryover of from 40 to 50 pes cent during years of average growth. Overuse of winter-fat for one or two years will not reduce its stand provided a good growth season reoccurs to revitalize old plants and to produce seed.

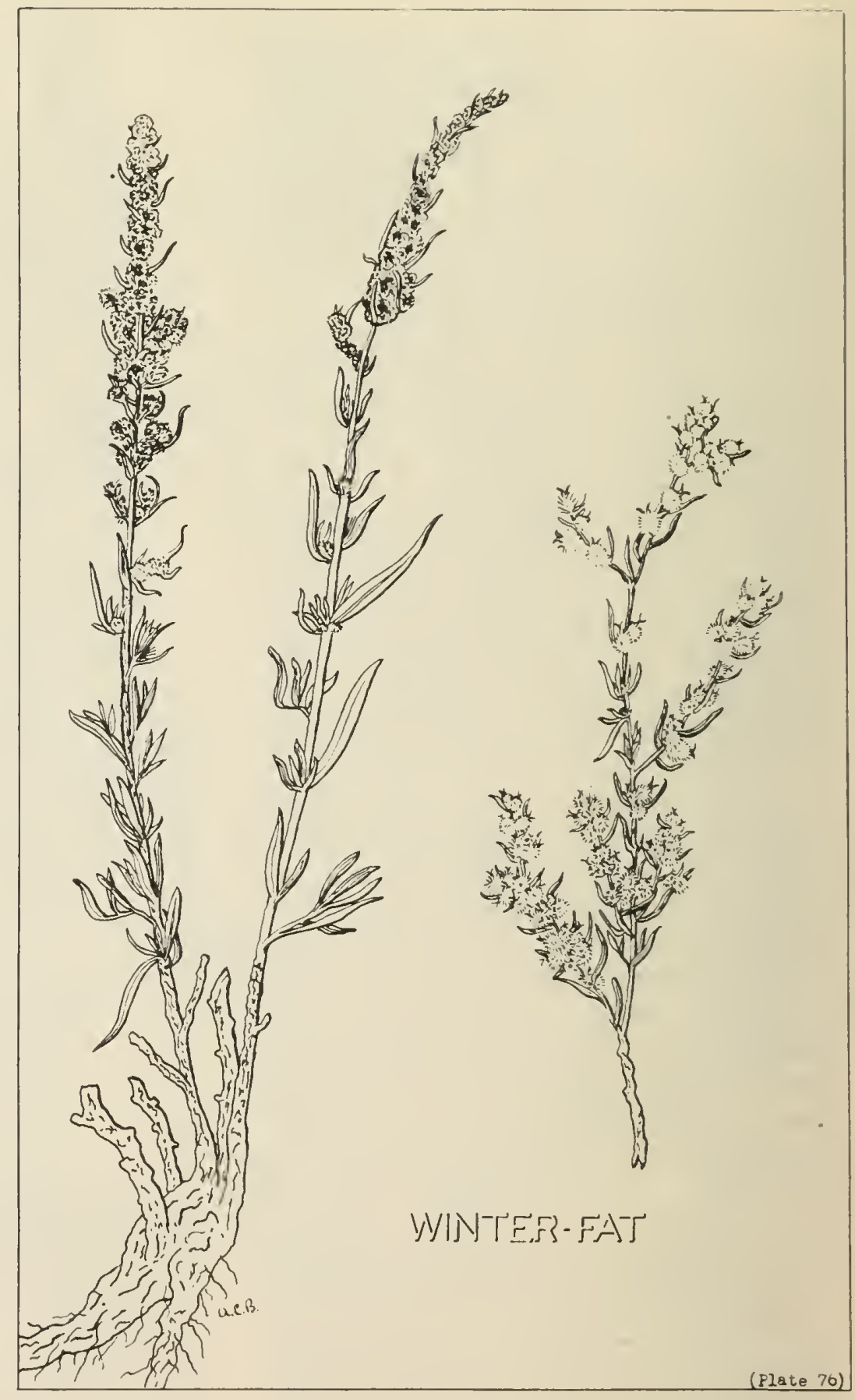

Winter-fat is a good ornamental plant, easily grown under dry conditions. 


\section{SASKATOON}

\section{Amelanchier alnifolia Nutt.}

Saskatoon, shadberry, service-berry, and June-berry are all conmon names for a native member of the apple family. It is found throughout the temnerate portions of North America and grows under a range of conditions fron dry sunny slopes to sharded sites in coniferous forests. In the Prairic Area it is an inhabitant of shaded coulees and the adjacent upland.

Saskatoon may be either a clense shrub or a small tree, although the shrub type is the more common. The ash-gray stems produce an abundance of round or round-oval leaves which are smooth on the unper side but hairy below. The upper portion of the leaf margin is saw-toothed, but the lower third or half will be entire; ten to fourteen pairs of conspicuous veins extend from the mid-rib to the edge of the leaf. The round fruit is purplish with a bloom.

Because of its wide distribution, palatability, and availability to grazing animals, saskatoon is recognized as one of the best browse plants for all classes of domestic livestock and game. As with other browse plants there will be a greater utilization after midsummer. Phosphorus analyses indicate a high content of that mineral during the entire year, while protein analyses show similar trends to the protein cycle of poplar.

Grazing may reduce its vitality but saskatoon is one of the most persistent browse snecies. As livestock graze the outer tips, there is a greater growth of the inner foliage, which in time may develop into short trees. Thus moderate rates of grazing improve the stand of this species.

There are several species of Amelanchier growing in North Anerica, although saskatoon is the

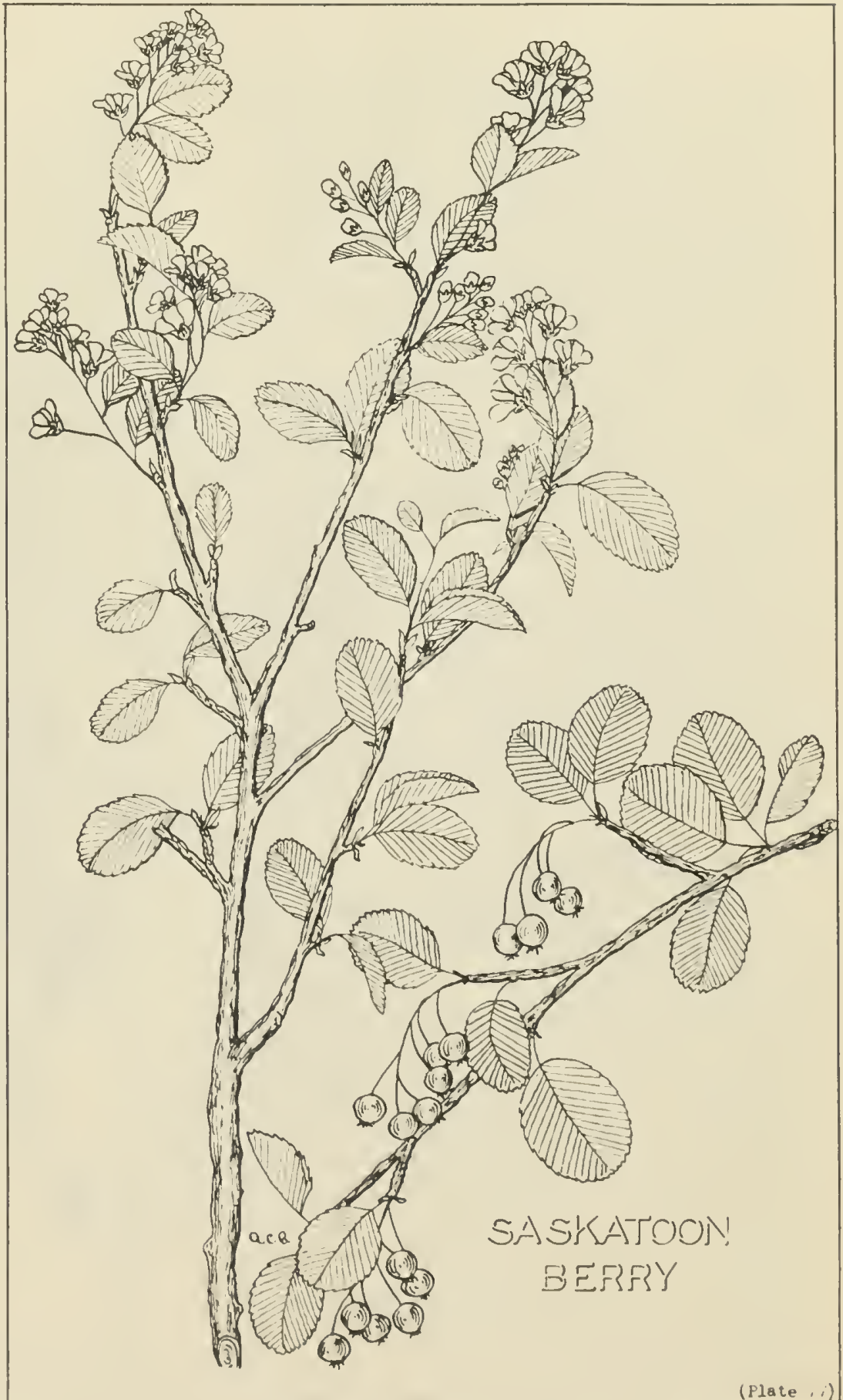

only one conımon in the l'rairic Area. All species produce edible fruit. 


\section{SHRUBBY CINQUEFOIL}

Potentilla fruticosa L.

A common range plant of the rose family is shrubby cinquefoil. It has a widespread distribution throughout Asia, Europe, and North America. It prefers valleys, bogs, or cool moist plateaus. In the Prairie Area it is abundant in the Foothills and Cypress Hills, while small stunted stands are found throughout the region. The name fruticosa refers to the shrubby type of growth. Other common names are yellow rose and buckbrush.

The cinquefoil grows from a woody crown which shows annular growth rings. The numerous 1 - to 3 -f oot stems are covered with shreddy thin bark, while the young branches are clothed with grayish hairs. The leaves have from three to seven leaflets whose bases are so close together that the leaf might be considered to be palmate. The leaflets are leathery, hairy, and pointed at each end. The plant produces yellow flowers and blooms from June until freezeup.

Cinquefoil is seldom eaten as long as other food is available. When sparse stands are heavily grazed or when heavy stands increase in density and size, there will likely be overutilization of the associated palatable grasses. Sheep will make greater utilization of cinquefoil than other domestic livestock or game. The surest method of control is to mow dense stands every third or fourth year, but rotations and moderate grazing rates will maintain associated grasses and forbs. It is an easily grown ornamental and valued for this purpose because it produces a profusion of flowers during a long season.

As with many other browse plants, cinquefoil leaves have a relatively high protein content ( 12 to 15 per cent on July 30 ), a low fiber content,

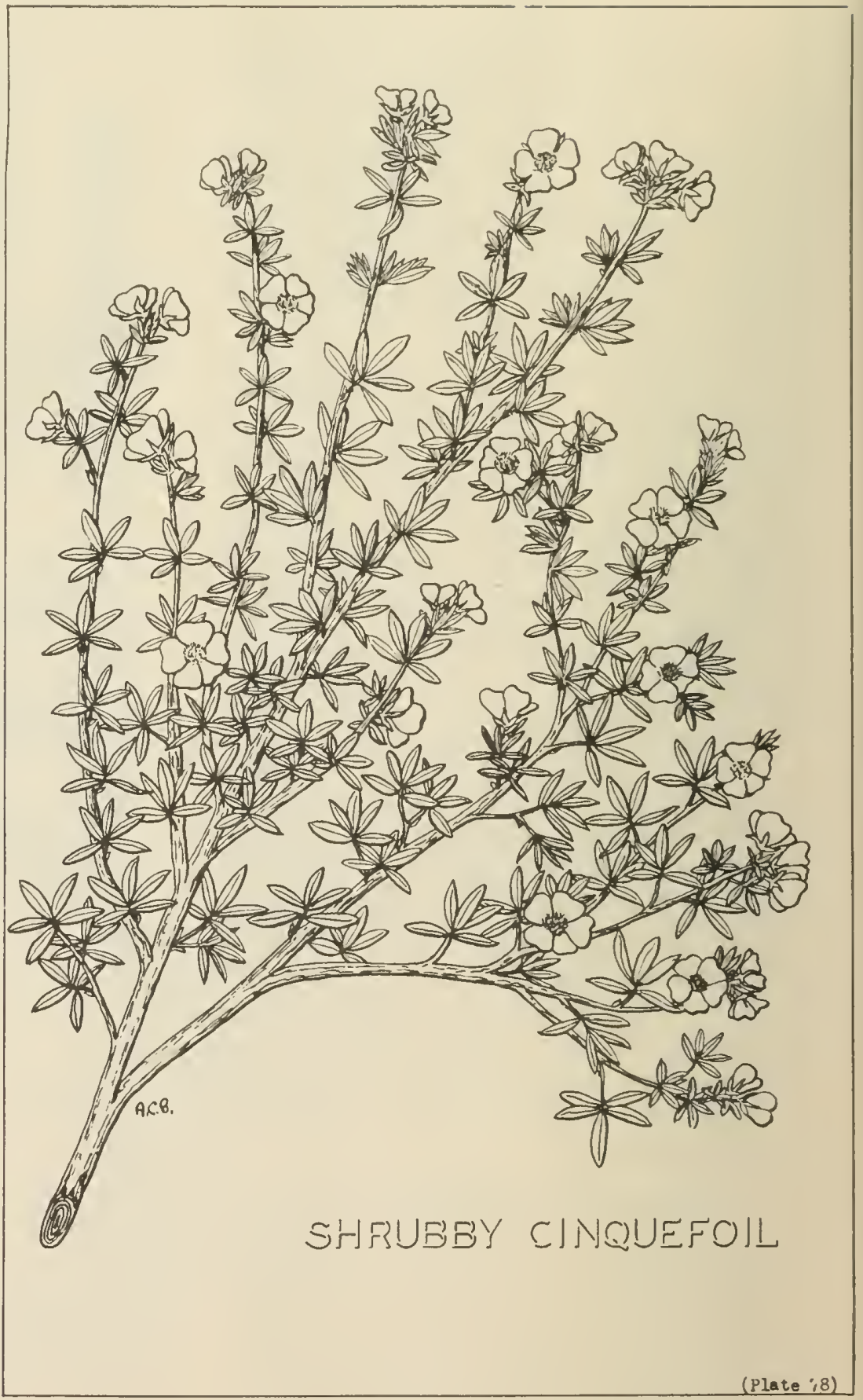

and considerably more phosphorus than the associated grasses. 


\section{ROSES}

Rosa spp.

Roses have a widespread distribution throughout the temperate zone of North America where nearly 100 different native species have beén identified. In the Prairie Area some eight or ten species are found, but only five or six are common. Of these the prickly rose, $R$. acicularis Lindl., which grows on the open plains and around bluffs, prairie rose, $R$. arkansana Porter, and Wood's rose, R. Woodsii Lindl., which blooms at the margin of bluffs and in open woods are the best known.

Roses as a group are easy to distinguish from other plants. Their brown spiny stems, small, green and saw-edged leaves, white, pink or red flowers, and their red fruits are characters easily recognized. However, it is often difficult to identify one rose species from another, not only because the characters of a species are variable, but because the species hybridize readily to create plants having characters of two or more species.

Palatability of roses varies greatly - between species, between districts, and between livestock. Sheep will browse the leaves and hips (fruits) of nearly all species and in fact will overgraze sparse or open stands. Cattle eat Wood's rose readily, especially in the autumn and on ranges where browse is more abundant than grass. In general, roses can be classified as less palatable than most grasses, but as palatable as most browse species, especially for sheep. Nutritive values, as determined by chemical analysis, are fairly well balanced with protein contents of 10 to 12 per cent during July and August. Phosphorus content is not so high as that of aspen, but still well above that of associated grasses. The fiber

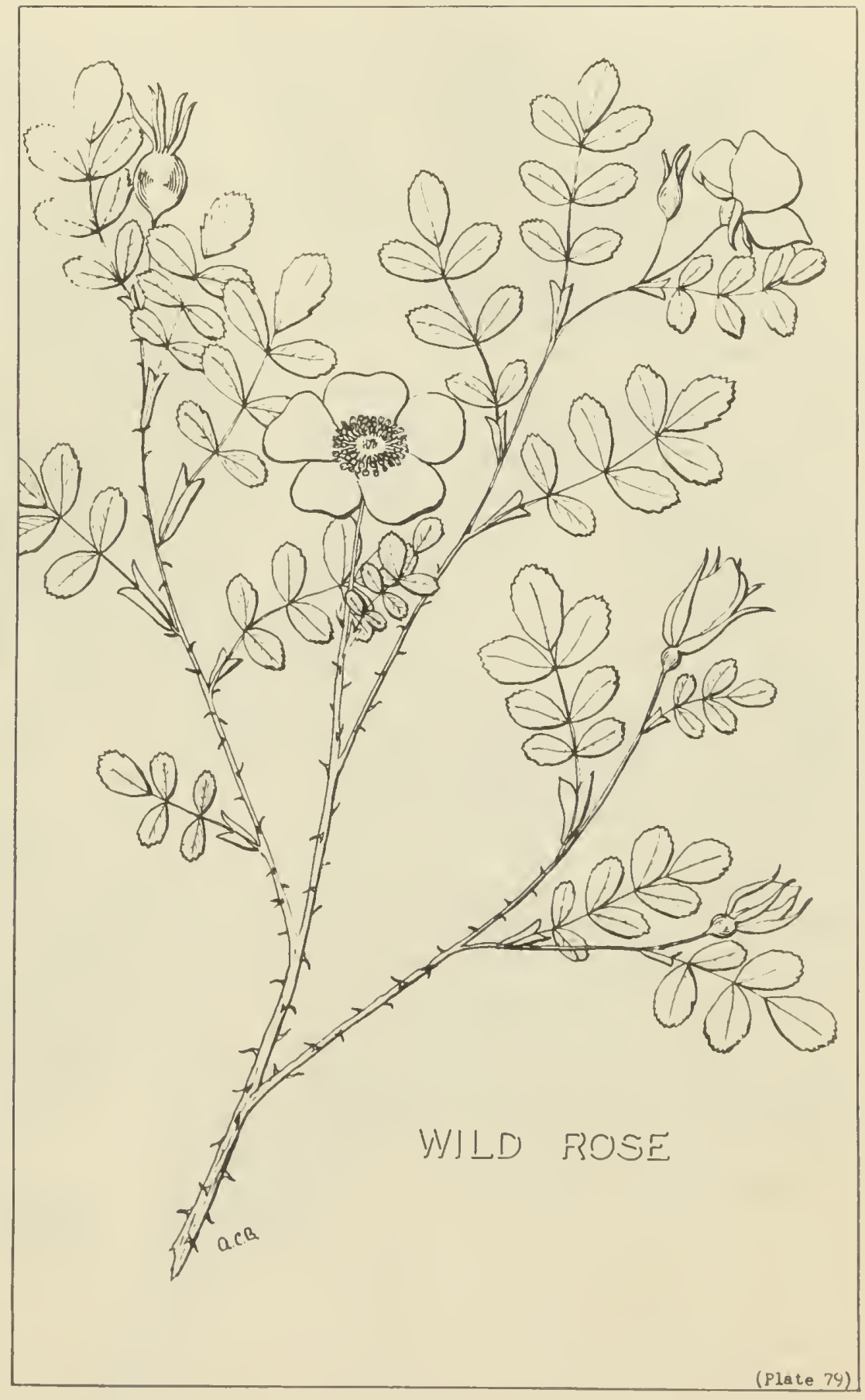

content of the leaves is low. 


\section{GROUND PLUMS}

Astragalus succulentus Richards and A. caryocarpus Kev.

The Astragalus or milk-vetch group is part of the pea family. Over twenty different species occur in the Prairie Area. Amongst these are species poisonous to livestock, as well as a few which are apparently palatable and nutritious.

Amongst the most interesting of the Astragalus are the ground plums. These two almost identical species cling to the ground, their stems creep between grass plants and their leaves intermingle with the grass leaves. Single plants may be as much as 3 feet in diameter. Small creamy flowers in A.succulentus and equally small purple flowers of $A$. caryocarpus develop into plum-shaped fruits up to $1 \frac{1 / 4}{4}$ inches in length. These are green in color before maturity but become pale brown or even reddish when ripe. It is reported that the Indians of the Prairie Area ate the green fruit either raw or boiled, while cattle have been observed to search pastures for both both fruit and leafage.

Ground plums are becoming rare. They preferred to grow in deep, fertile soils which were selected by homesteaders as the best farm land. In addition they have been heavily grazed. Although there are few records indicating their nutritive qualities, those available suggest relatively high protein and low fiber contents.

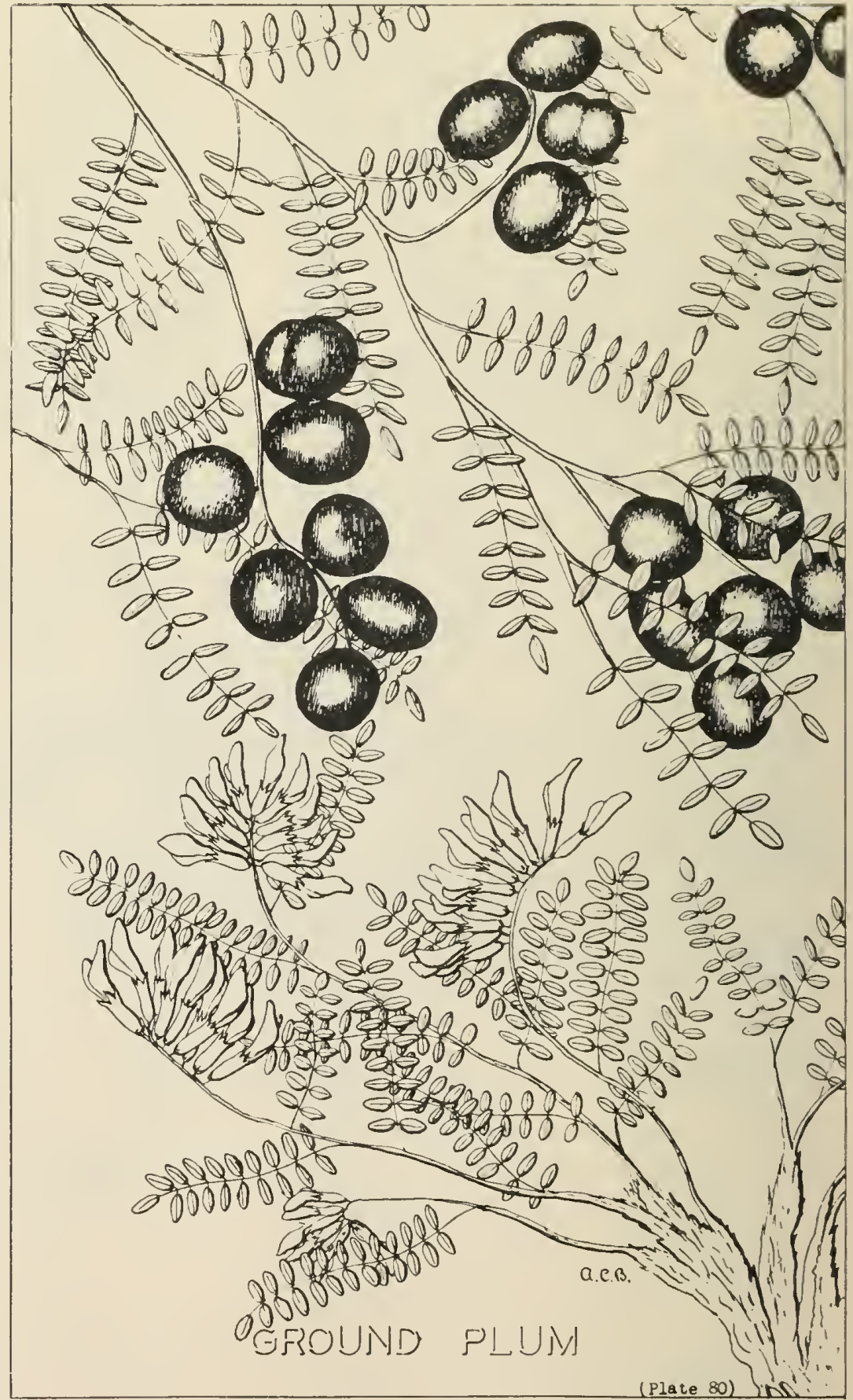




\section{Hedysarum americanum (Michx.) Britt.}

Hedysarum species are members of the pea family found throughout the north temperate zone. They are abundant through the Foothills, the Cypress Hills, and northward from the grassland-forest boundary across the Prairie Area. Of the four known native species, American hedysarum is the most common.

American hedysarum is a fairly erect plant. Its compound leave may bear up to ten pairs of leaflets. The leaflets help to identify the group because they are covered with glandular dots. The flowers are from white to purple and grow in racemes at the end of the erect stems. The flat seed pods are unique - there is a constriction between each seed and the pods break between the seeds rather than splitting along the back. Conspicuous veins run across the seed pod.

Reports on its nutritive value vary considerably, but mistaken identification is one cause of the variable reports. In general hedysarum species are palatable to sheep and fairly so for cattle during midsummer and early autumn. Overuse of these species usually indicates an overgrazed range.

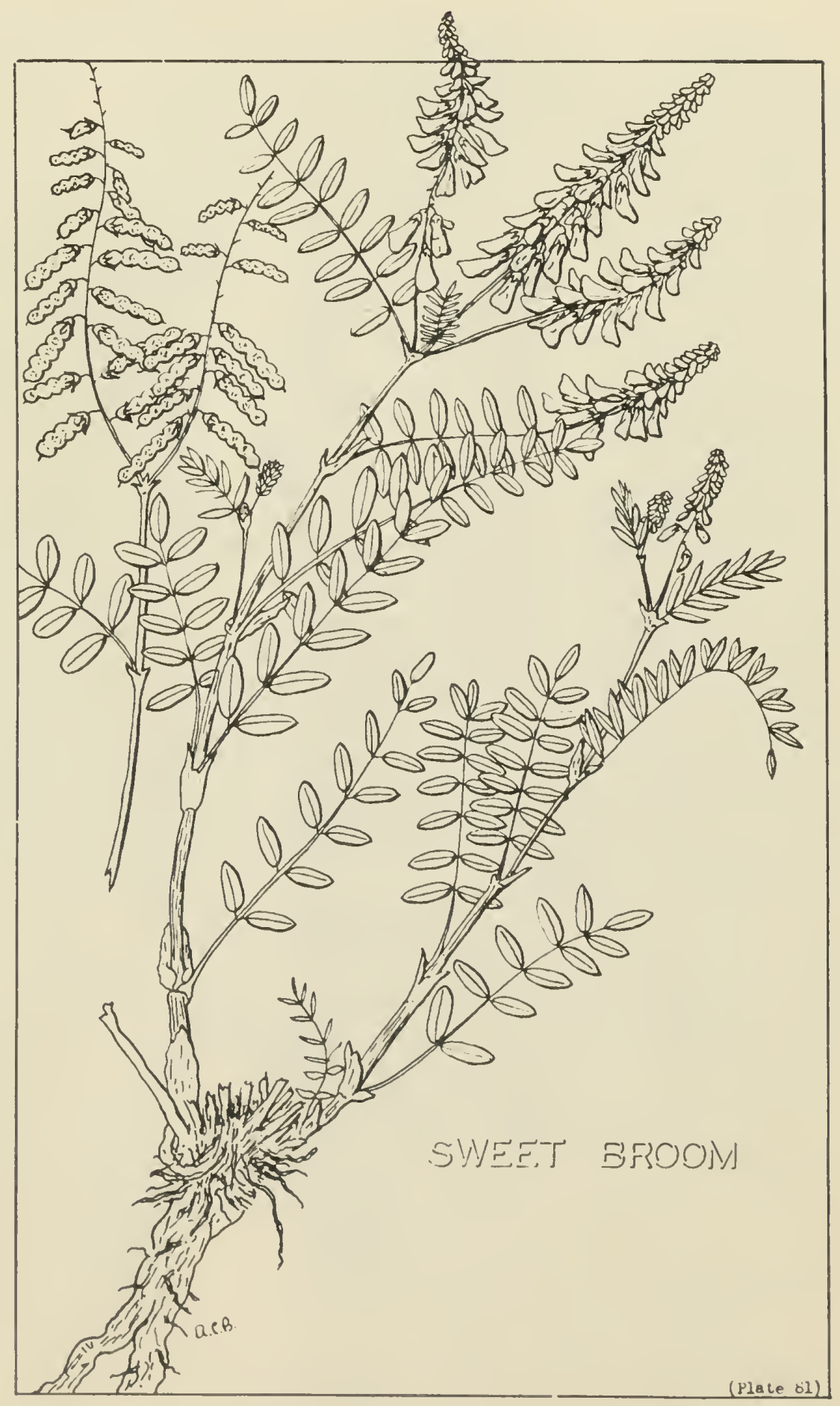




\section{PEA-VINE OR VETCHLING}

Lathyrus venosus Muhl.

Pea-vine is the most common of the four Lathyrus species that grow in the Prairie Area. It has a wide range as it grows from Quebec to British Columbia and southward as far as Georgia, Louisiana, and Texas. Pea-vine is a plant of bushland and forest where it often dominates the understory. The other native species likewise occur in woodlands, but in addition may also be found on the shores of lakes and marshes throughout the open prairie. It is a member of the pea family.

Pea-vine is a climbing plant with four angled stems growing from a woody root. Its leaves have four to six pairs of smooth oval leaflets, while a tendril replaces the usual leaflet at the tip. The twelve to sixteen purple flowers grow in a fairly dense raceme and develop into flat veiny pods up to 2 inches in length. One native species, L. ochroleucus Hook., has creamcolored flowers; it is commonly found in bushland but may occur in the southern part of the Prairie Area.

Pea-vine is palatable. Cattle, sheep, and horses seek it out and fatten on its lush foliage and abundant seed. Unfortunately, the plant does not cure and, as frost will destroy its nutritive qualities, it should be grazed before late summer. Because of its palatability it is easily overgrazed and as its stands disappear the value of bush pasture is reduced accordingly. Fortunately, the woody root will persist for many years, and if bush pastures are rested, pea-vine often makes a marvellous recovery. No management plan has been worked out to maintain this valuable native forage, but grazing should never be heavy enough to graze off all the seed pods. Nutritive qualities as determined by chemical analyses are excellent, with

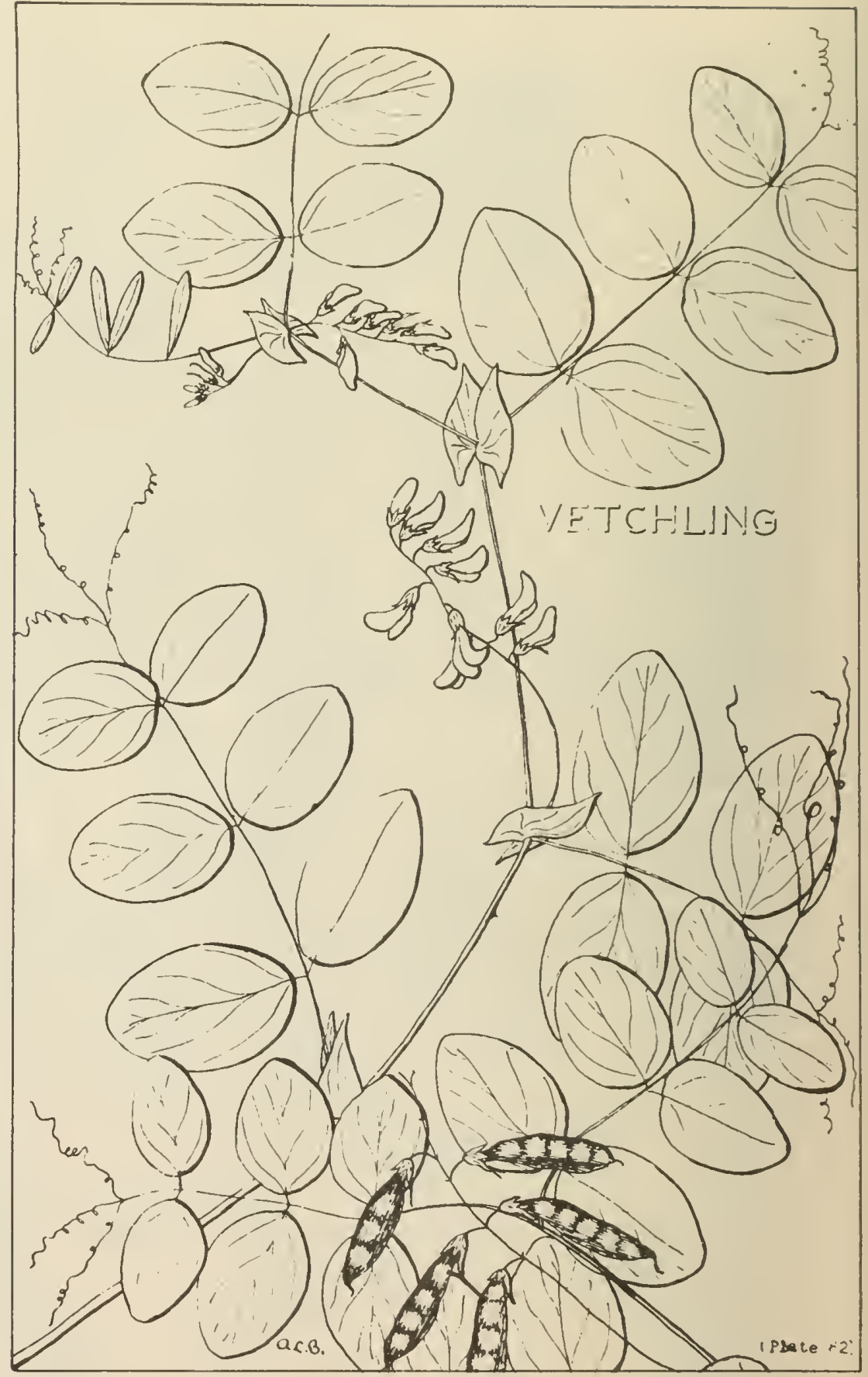

as much as 30 per cent crude protein in the young leafage. 


\section{SILVERY LUPINE}

Lupinus argenteus Pursh.

Lupines are showy members of the pea family which have palmately divided leaves and long brightly colored flower spikes. Five species are native to the Prairie Area; but only the silvery lupine is widespread and of importance as a forage herb. The scientific name "Lupinus" is derived from the Latin meaning "wolf", while one of its many common names is wolfbean. In the Prairie Area, silvery lupine occurs only in the Cypress Hills, the Milk River bench, and in the Foothills about as far north as Rocky Mountain House.

Silvery lupine is a herb which grows from a persistent woody root. The several stems reach a height of 30 inches and are covered with short hairs. Leaves have from six to ten leaflets all growing from a single point, each of these may be over 2 inches in length and are usually hairy. The long racemes bear many white to violet or rose flowers from which hairy pods containing five to six seeds develop. The woody root will persist in cultivated fields; otherwise clean summerfallow may have one to five or more lupines per acre.

Opinion is divided as to the forage value of silvery lupine. In the Intermountain States it is classed as poisonous to sheep and toxic to cattle and horses when grazed; as it is quite palatable it can with reason be classed as a menace in that area. However, no reports of livestock poisoning are available to indicate that it has poisonous properties on prairie pastures, in fact it is considered to be an excellent constituent of upland hay in the Foothills.

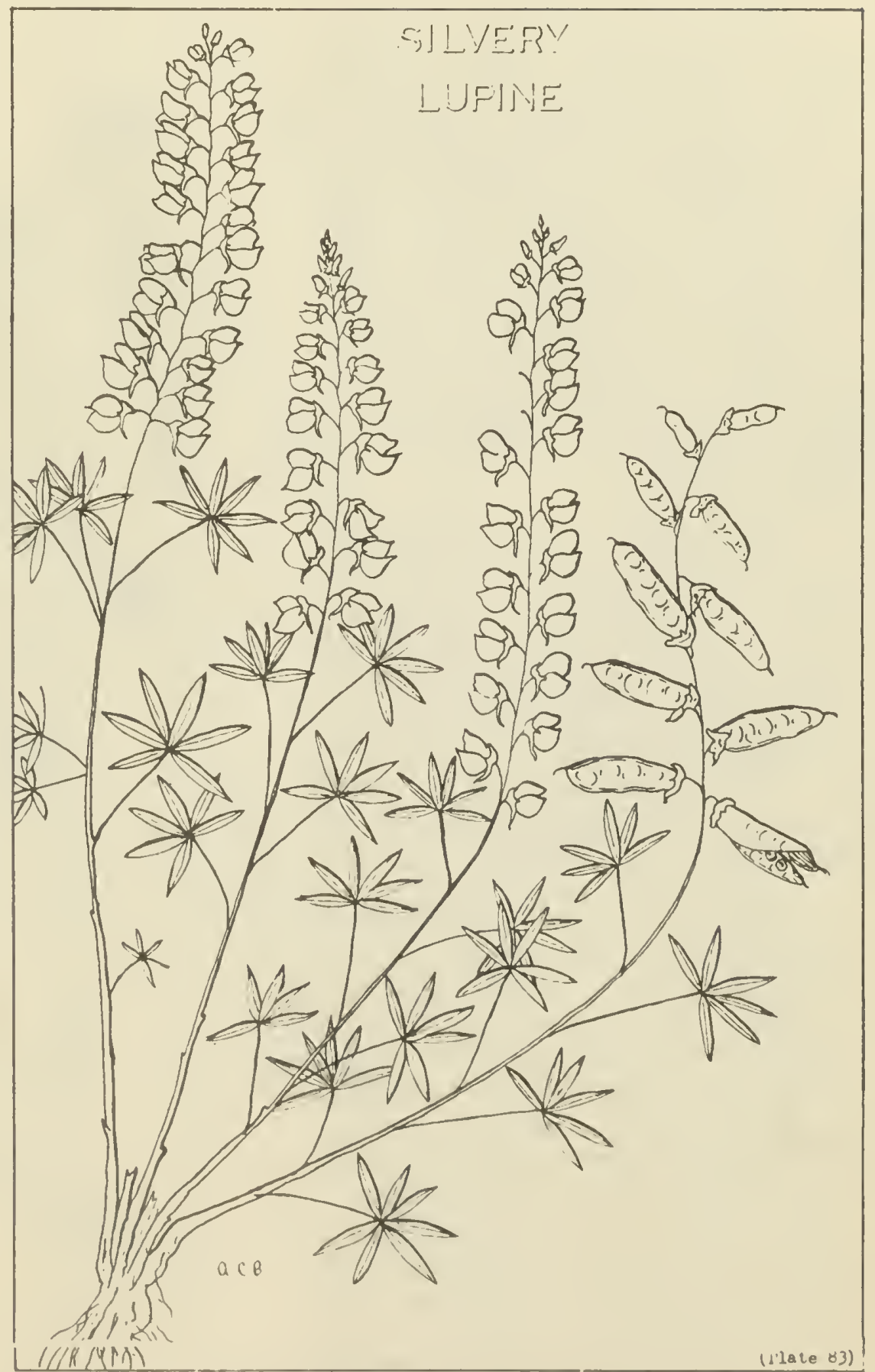


Medicago sativa L.

Alfalfa or lucerne spread throughout Europe and Asia from its home in Asia Minor prior to and following the beginning of the Christian era. It was introduced into North America early in the 18th century but its value was not recognized until after 1850. The variety Grimm was selected from seed imported from Germany, while the Ladak variety was developed from seed obtained in Northern India. Siberian alfalfa, 11. falcata L., was imported from Central Siberia. It is the most cold and droughttolerant of the several species comprising the group.

Alfalfa, is a deep-rooted herb with a woody crown that grows immediately above or below the surface of the ground. It has numerous three-leaflet leaves crowding the 2- to 3 -foot stems. The purple flowers of $M$. sativa develop into coiled pods containing up to ten seeds, while the yellow flowers of $M$. falcata grow into easily split sickle-shaped pods with only three or four seeds.

Alfalfa is palatable to all classes of livestock and is considered one of the best pasture and hay plants throughout the temperate zones of the world. Its digestibility when fed alone is not high, seldom over 55 per cent on a dry-matter basis, but its high protein and mineral contents make it an excellent supplementary feed to balance rations. When mixed with native hays, it increases their digestibility and apparent palatability. When grown in mixtures with grasses, it lengthens the life of the stand while the mixt ure will outyield either grass or alfalfa grown alone. It is the best legume crop for irrigated land and has produced excellently on dry land.

Improved va ieties and strains are becoming available. Disease resistance, drought tolerance, and winter hardiness are being bred into the high producing varieties, and selections are being made

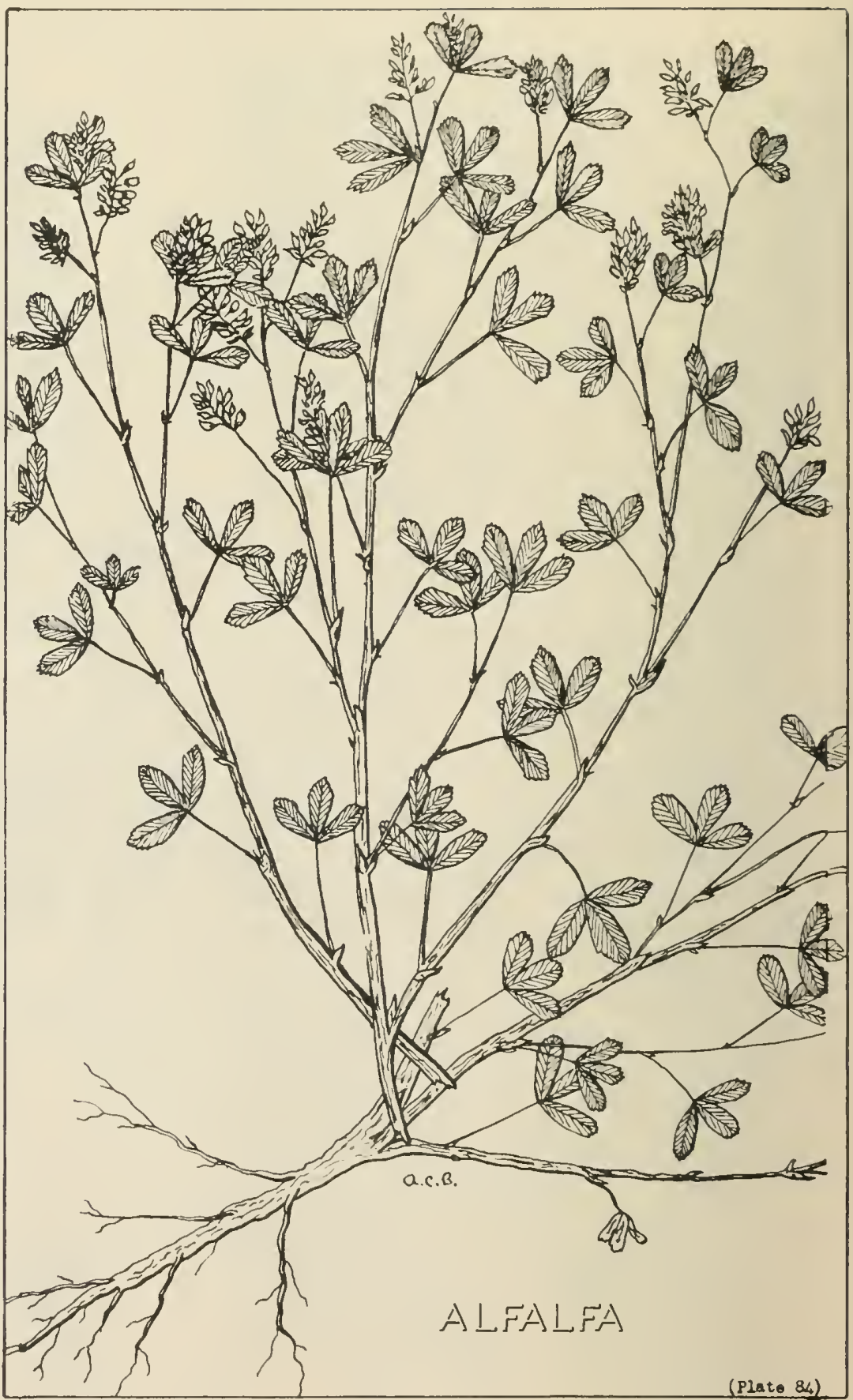

from this material for pasture and hay.

Alfalfa may cause bloat when pastured. However, grass-alfalfa mixtures are less dangerous than alfalfa alone, dryland pastures less hazardous than irrigated fields, and continuous grazing less risky than rotations . 


\section{SWEET CLOVER}

Sweet clover is a native of Asia Minor that was introduced into North America in the early $1700^{\prime}$ s. It was considered to be a weed for nearly 200 years and only since 1875 has it become recognized as a valuable forage plant. As with most members of the pea family, sweet clover produces nodules on its roots which extract nitrogen from the air for the use of the plant.

Sweet clover is a sweet-scented upright annual or biennial herb. It produces three-leaflet leaves which are saw-toothed around most of their edges. Flower racemes grow from the axils of the leaves and produce many white or yellow florets, each of which may develop a seed pod usually containing one seed.

There are two common sweet clover varieties - white, MI. alba Desv., and yellow, $M$. officinalis (L.) Lam. They can be distinguished by the yellow flowers, the shorter and finer stems, more spreading growth, finer leaves, and the purple-flecked seed of the yellow-flowered species. Both of these species are biennials, that is, they produce seed during their second year of growth.

Sweet clover has a well-balanced nutrient content during its early growth, but loses much of its protein as the plants mature. In its young stages of growth it provides palatable pasture for all classes of livestock and when cut early and cured it makes a desirable hay. Its high coumarin content quite often prevents stock from eating it until they become accustomed to the some what bitter flavor. Spoiled sweet clover hay may be harmful to livestock as decomposition of coumarin results in a toxic compound which causes bleeding. In many districts sweet clover has been used

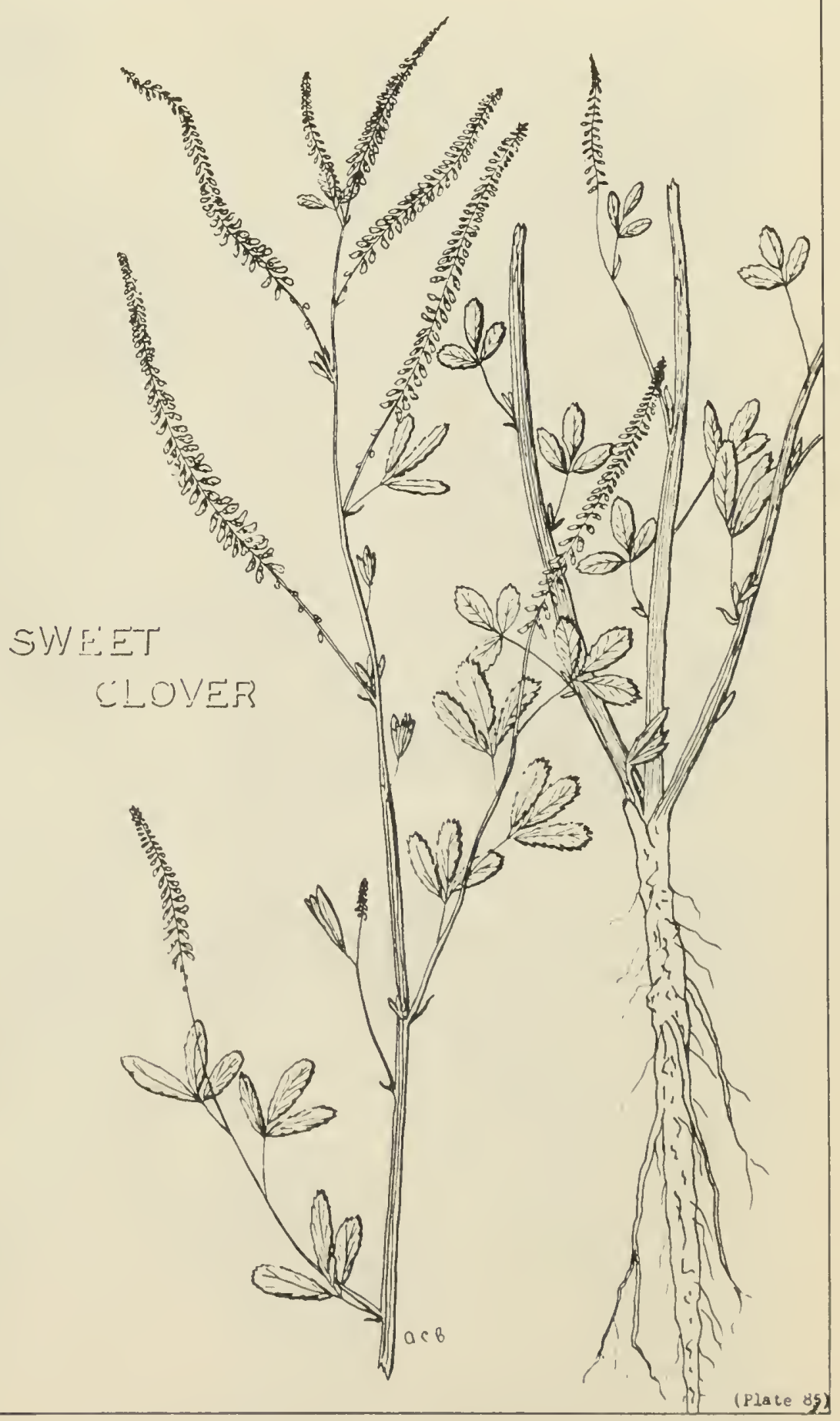

to control the growth of noxious weeds and to build up organic matter content of soils. Sweet clover is recognized as one of the best bee pastures available. 
The true clovers form a large group of the pea family. A few are native to Canada, but those of economic importance have been introduced from Europe where they have been cultivated for several hundred years. The species of agricultural importance in the Prairie Area are white clover, Trifolium repens L., alsike clover, T. hybridum L., and red clover, T. pratense L. Each of these species has named varieties which are adapted to certain districts or soils.

White clover has creeping stems which root and produce new plants, but neither the red nor alsike has this character; both grow from crowns. All species produce three-leaflet leaves which have finely toothed margins. Flowers are borne in crowded heads and develop small pods hidden in the dry flower parts. Most of the true clovers are perennials but a few species of little economic importance are annuals or winter annuals.

Clovers generally are palatable to all classes of livestock. Their high protein contents are valuable qualities to supplement poorer quality feed. Bloat may occur on particularly lush pastures, with the white clover being most dangerous. Reports state that clover leaves have been used as a human food, particularly in salads, while dried flowers and seeds have been made into flour for pastry and bread. Most of the true clovers produce good bee pasture.

True clovers have considerable economic importance for pasture purposes at the margin of the Prairie Area and for irrigated pasture within the drier sections of the region. They respond well in districts where the rainfall is greater than 17 inches per year and where the soil contains satisfactory levels of phosphorus and calcium.
Trifolium spp.

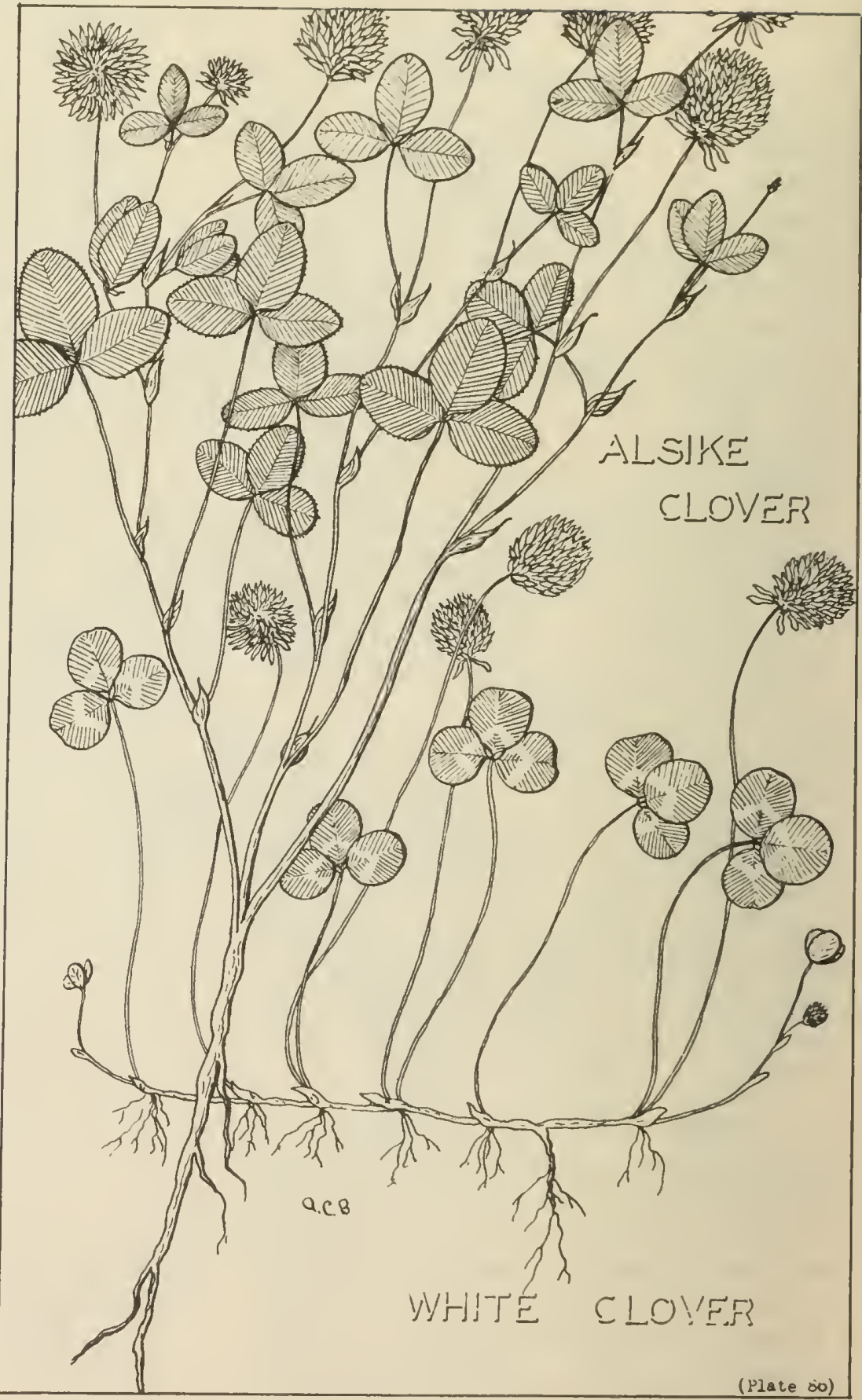

(Plate io) 


\section{VETCH}

Vicia spp.

There are two common vetches growing in the Prairie Area. The narrowleaved vetch, $V$. sparsifolia Nutt., is common throughout the grassland portion of the region, while American vetch, $V$. americana Muhl., is abundant at the margins of bluffs and throughout open woods. A few other species occur rarely, while one, tufted vetch, V. cracca L., is imported and has escaped from cultivation. Vetches are members of the pea family.

Vetches are weak-stemmed 1, rbs which often appear to be vines. Their four-angled stems are easily broken. Leaves consist of six to twelve or more pairs of leaflets with a tendril or tendrils growing at the ends of the leaves. The flower stalks grow from the axil of the leaves and produce a few flowers at their tips. Seed pods are flat and break open easily. The leaflets of the narrow-leaved vetch are narrow and spear-shaped at each end, those of American vetch are broadly oval and have a tip at the end.

Vetches have characters similar to many other legumes. They produce nodules on their roots which contain bacteria to synthesize atmospheric nitrogen, they have the characteristic flower and pod, they are useful for green manuring, and are fair to good bee pasture. However, it is doubtful if vetches generally are as palatable to livestock as most other legumes. Certainly the native species are not so valuable in this regard. Chemical analyses reveal a high spring and early summer protein content and a relatively low crudefiber percentage.

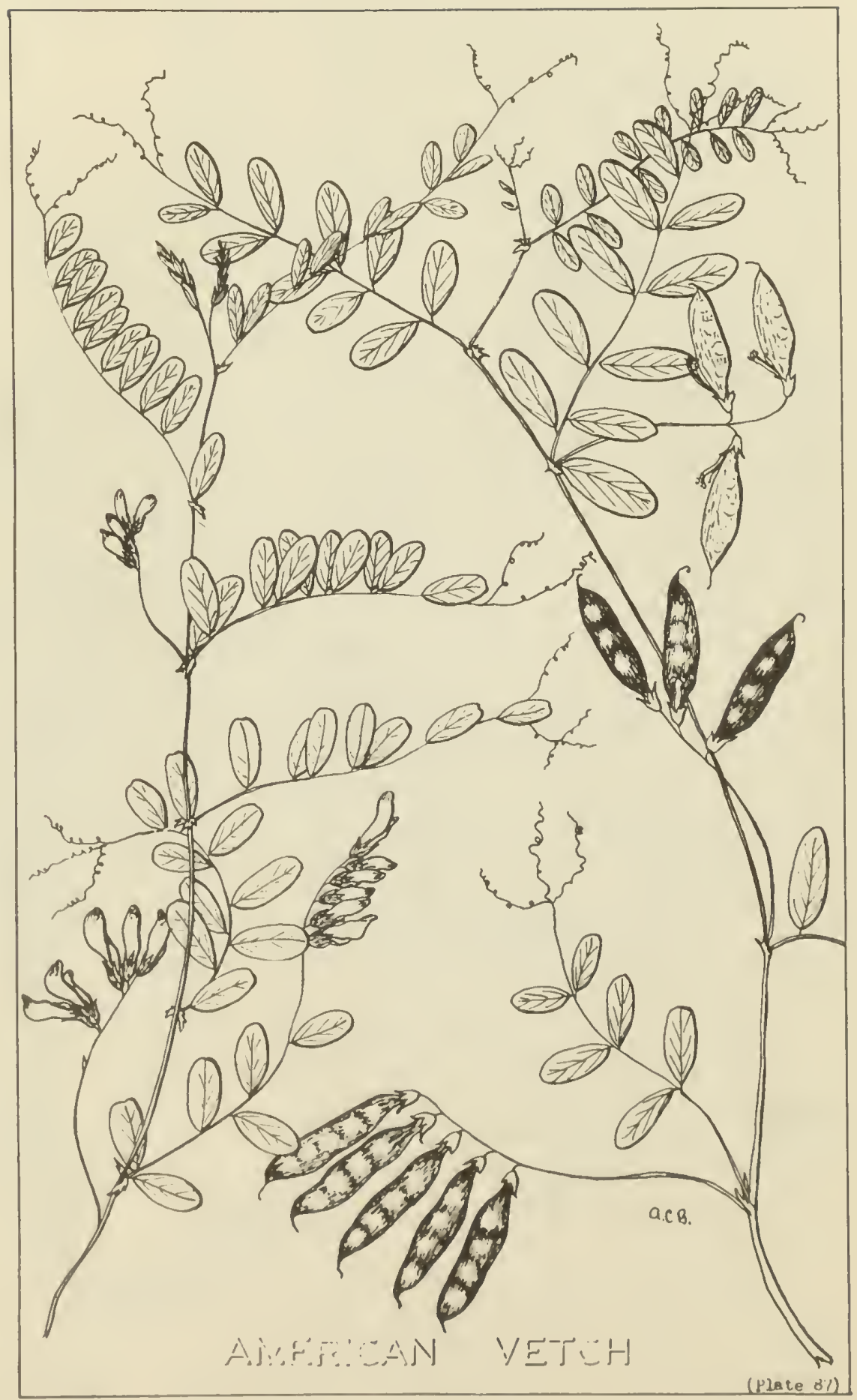




\section{FIREW EED}

Epilobium angustifolium L.

Fireweed is one of the most common members of the evening primrose family growing in the Prairie Area. It has a wide distribution throughout Asia and Europe, while it is common in North America from Newfoundland to Alaska and from the northern limits of growth southward through the United States and into Mexico. Its common name "fireweed" is very apt as it is one of the first plants to invade fireblighted forests. It is also called willowherb because its leaves resemble those of willow and its mass of silky seeds are suggestive of willow catkins. In the Prairie Area it will be found around bluffs and sloughs, in open forests, along roadsides, and throughout moist prairie. It is not common in the dry central region.

Fireweed grows from long creeping roots. Its leafy stems may be as much as 4 feet tall. It has a long flowering season bacause the lower florets blosson first followed in succession by those nearer the the top of the stem. The narrow leaves become red in the autumn. The long flower stalk bears pink or purple flowers which develop into four-sided pods filled with numerous small seeds, each with a parachute of silky white hairs.

Reports vary considerably regarding the grazing value of fireweed. Sheep make good use of it, but apparently require other fodder to balance the ir rations. Cattle will browse it occasionally, while horses and game seldom eat it. Fireweed is excellent bee pasture.

Heavy grazing early in the season increases tillering and the pasture yield during the current season. Although this practice will eventually reduce the vitality of individual plants, it is one which should be followed in

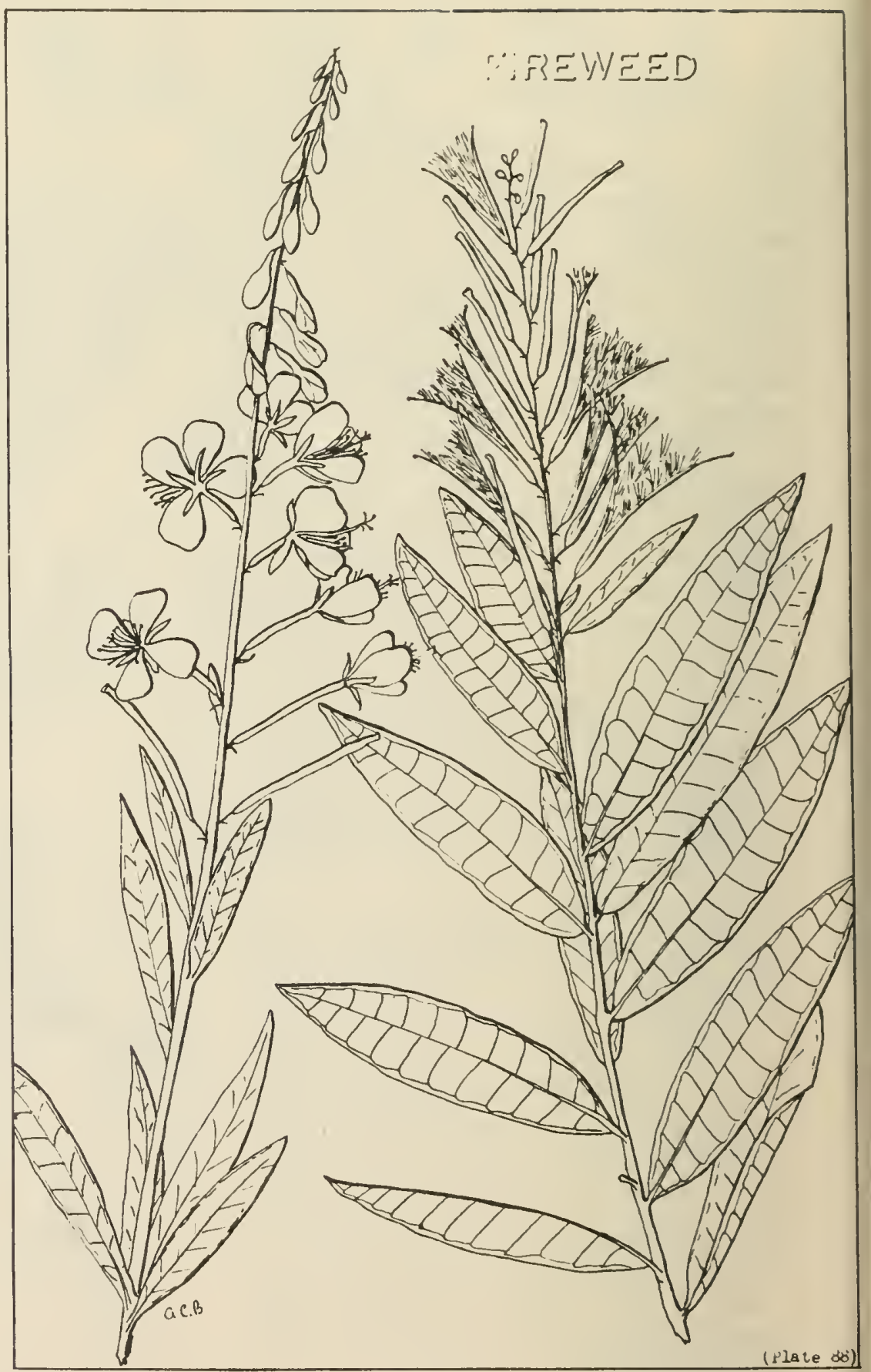

an effort to reduce the fire hazard created by heavy stands. 


\section{Osmorhiza spp.}

Sweet cicely is a member of the parsley or parnip family which is common in the wooded regions at the boundary of the Prairie Area and throughout the Cypress Hills and Foothills. There are two important species, smooth sweet cicely, $O$. longistylis (Torr.) DC., which occurs principally in the Southern Foothills and blunt-fruited sweet cicely, O. obtusa (Coult. and Rose) Fern., which may occur anywhere within the region. Sweet cicely is known also as sweet anise and sweet root.

The parsley family is a large one. It includes useful range plants such as sweet cicely, as well as those with poisonous properties such as water hemlock. Fortunately, water hemlock can be identified readily because its several tuber-like roots and its cross-sectioned crown are not possessed by other members of the family. Because the leafage of sweet cicely can be confused with that of water parsnip, the root character should be checked to ensure identification.

Sweet cicely is a tall herb growing from a single thick aromatic root. There are from three to five leaves on each leaf stem, and these are divided into leaflets each of which will be deeply toothed. There are relatively few white or purple flowers, which develop into deeply-grooved fruits from $1 / 2$ to $l$ inch in length.

All portions of sweet cicely plants are relished by sheep and cattle and will be eaten by horses and deer. However, its palatability and nutritive value will be destroyed by frost. Because it stores food reserves in its fleshy root, it can be grazed fairly intensively without killing individual plants or overgrazing stands.

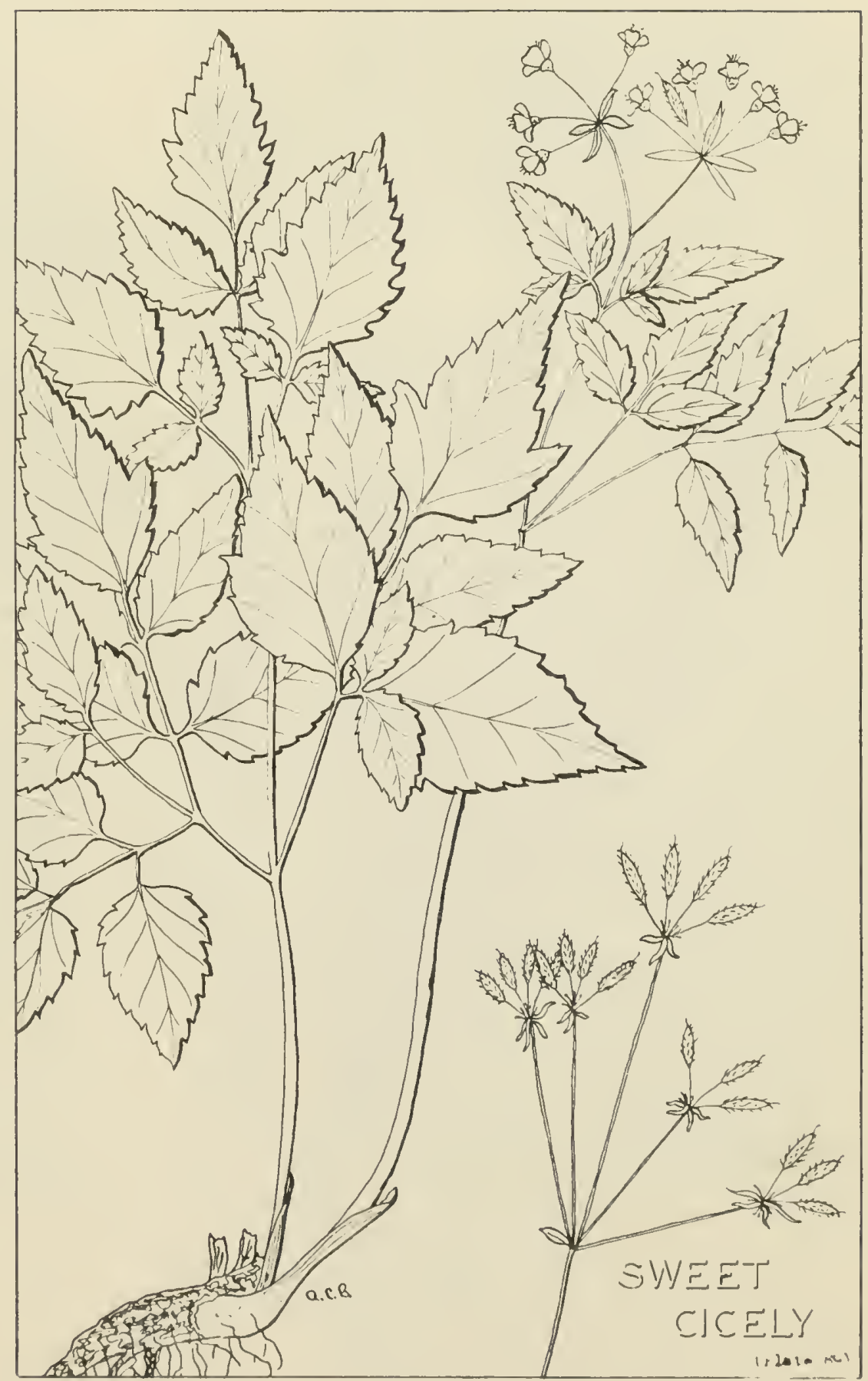


Sanicula marilandica L.

Snake root is another member of the parsley family common in moist woodlands at the edge of the Prairie Area, but rarely encountered in the drier central portion. It seldom grows in dense stands, but the leafy individual plants add considerable fodder to the associations where it is common.

Snake root is a perennial herb. It produces three to four stems which grow from a twisting rootstock. Its leaves are palmately divided with from three to five leaflets growing from one point. As with other members of the family, the leaflets have saw-toothed edges. Flower clusters grow in balls about $1 / 2$ inch in diameter. Seeds are about $1 / 4$ inch in length and are covered with fine hooked bristles.

This plant will be eaten readily by sheep and cattle during its early growth, but loses its palatability by the time it flowers. This is a character possessed by several nembers of the parsley family including musineon, ilusineon spp., squaw root, Perideridia spp., cow parsnip, Heracleum lanatum Vichx., water parsnip, Sium suave Walt., biscuit root, Lomatium spp., alexander, Zizia spp., as well as others. Thus they add considerably to the forage supply at a season before the grasses have completed their growth. In general, all the plants mentioned can be utilized quite heavily, not only because they produce quantities of seed, but their fleshy roots store reserves of food.

The Indians used the fleshy roots of many native members of the parsley family as sources of food and medicine. The roots were eaten raw, baked and roasted, or dried and ground into flour for biscuits, while the young leaves were collected for greens. The common

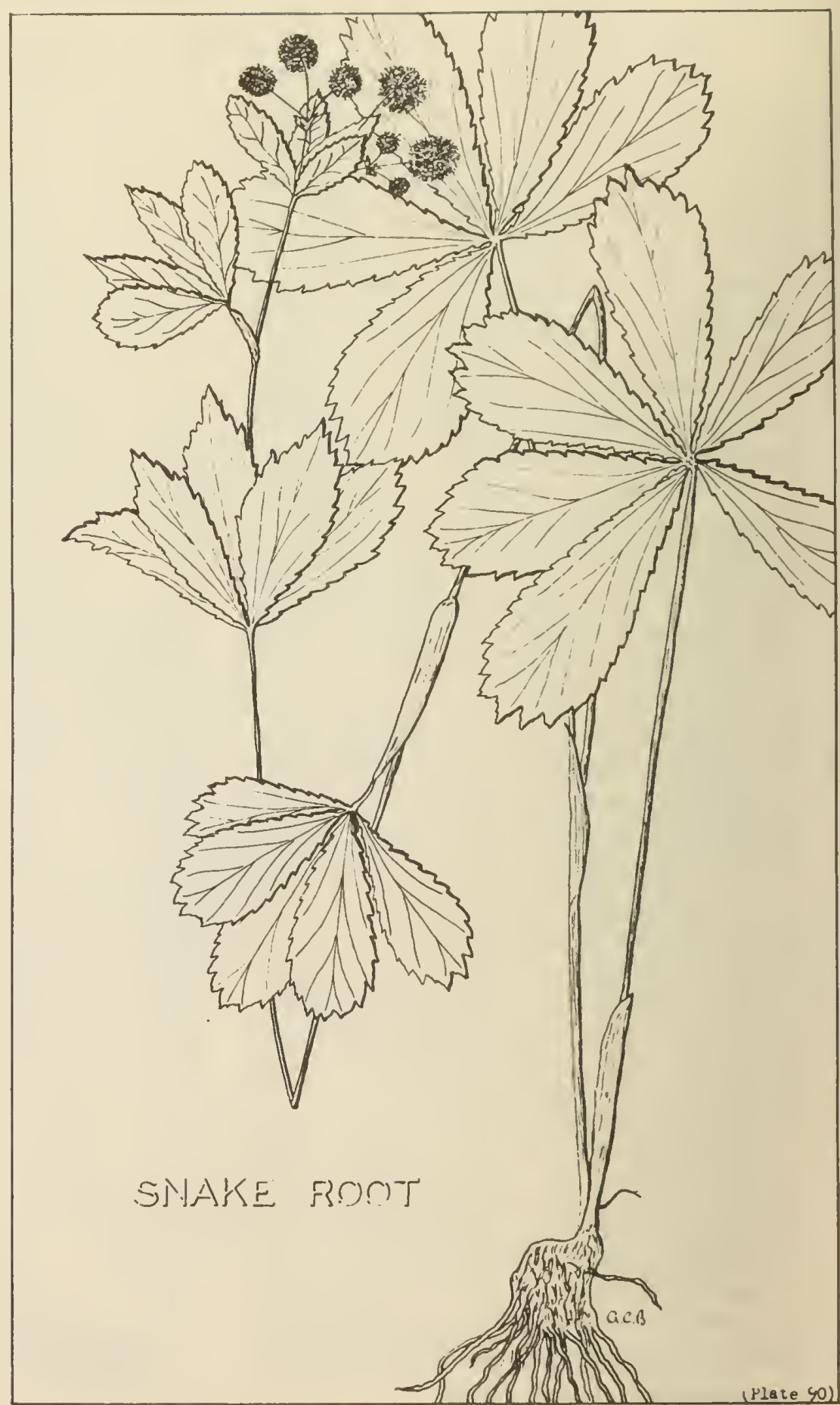

names of biscuit root and squaw root suggest the value of these plants for food. 


\section{INDIAN PAINTBRUSH}

Castilleja mineata Dougl.

Indian paintbrush is the most common of the eight Castilleja species growing in the Prairie Area. It, as well as the other members of the group, occurs as a rather unimportant but colorful member of the open forest communities. Paintbrush seldom grows in a dense stand, but as spaced individuals amongst grass and shrubs. The paintbrushes are known also as painted cups. They are members of the figwort family.

Semi-parasitic in nature and with small root systems, paintbrushes are short sparsely leaved herbs. The distinctive red, crimson, or yellow portion of the flower cluster is not a part of the flower proper, but rather small colored leaves which enclose the true flower parts. All leaves whether stem or flower enclosing are narrow, without stems, and usually entire.

The figwort family has many members amongst the range vegetation of the Prairie Area, several of them quite abundant. However, except for the paintbrushes, none of this numerous family is palatable. Even paintbrushes are not eaten readilybycattle, but sheep graze them throughout the summer.

Paintbrush is a very descriptive name for this group of plants. Their general appearance is that of a brush whose tip has been immersed in red and yellow paint. Because they have a long growing season, they add color to the sward before, during, and after the blooming period of most range flowers.

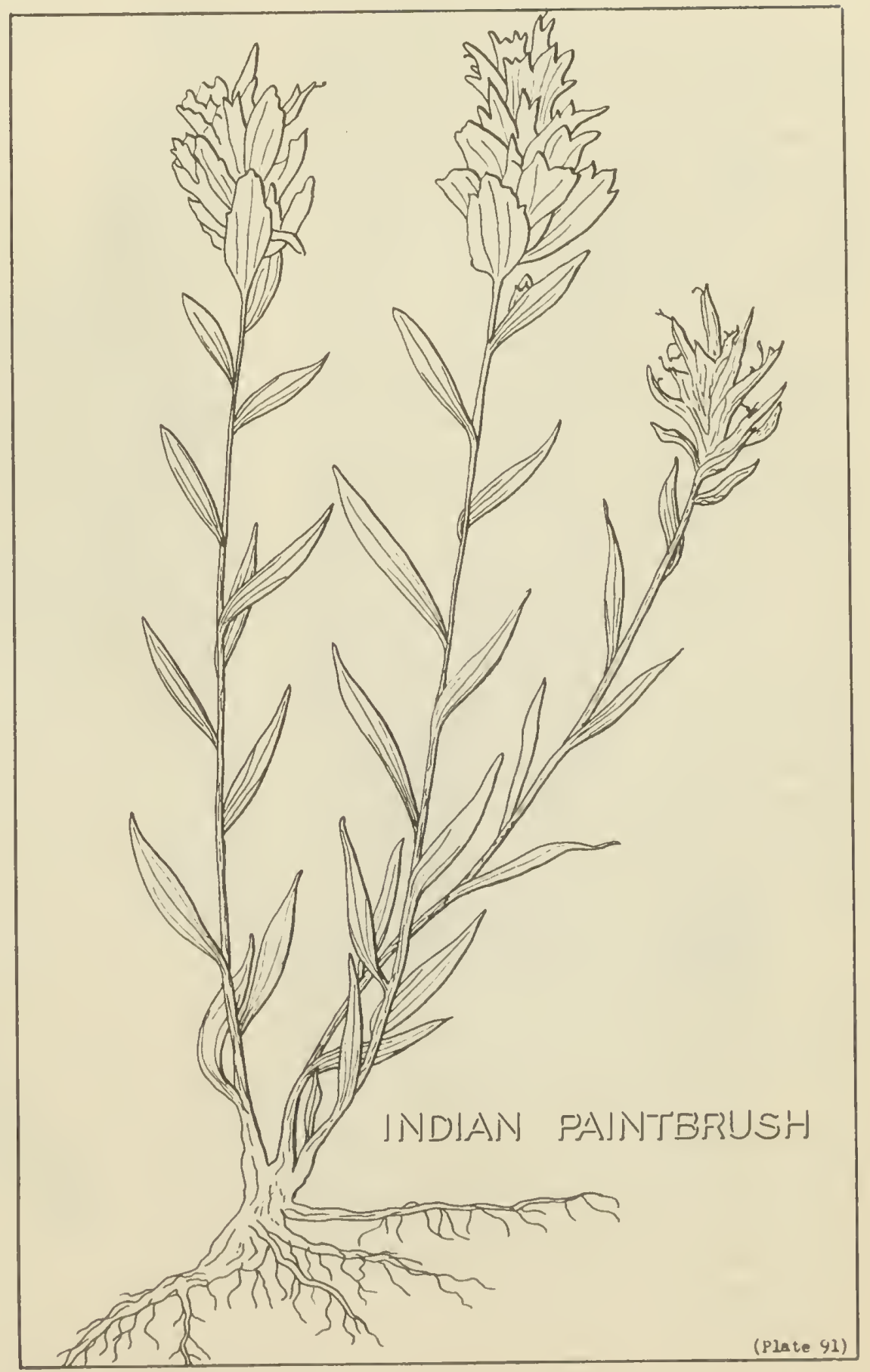


Artemisia cana Pursh.

Hoary sage bush is a shrub member of the thistle family that inhabits the central and western portion of the Prairie Area. It is found northward as far as the Parkland and extends southward through Montana and Utah. Hoary sage bush belongs to the dry plains and sand region and produces its heaviest known stands in the Great Sand Hills of western Saskatchewan.

The 1- to 4-foot tall shrub has a deeply penetrating tap root. Its bark is gray in color and often shredded. The leaves are up to $1 \frac{1}{2}$ inches in length, silvery hairy on both sides, and occasionally toothed at the end. The tiny yellow florets are crowded into a leafy panicle.

A closely related species, big sage bush or black sage, A. tridentata Nutt., occurs only at one known point in the Rocky Mountains in Alberta. However, it is the dominant species over extensive areas in Central British Columbia and throughout the Intermountain Area of the United States. It is distinguished from hoary sage bush by the three indentations at the tips of the leaves, as well as by its larger size.

Hoary sage bush cannot be classified as palatable, although it is eaten on occasions. Sparse stands on sheep range will disappear quickly, but heavy stands seldom show any evidence of utilization. Cattle do not relish the plant but will thrive when forced to feed on it. Chemical analyses indicate that the leaves of hoary sage bush will have over twice the protein, phosphorus, and fat contents of the associated grasses during the summer and autumn.

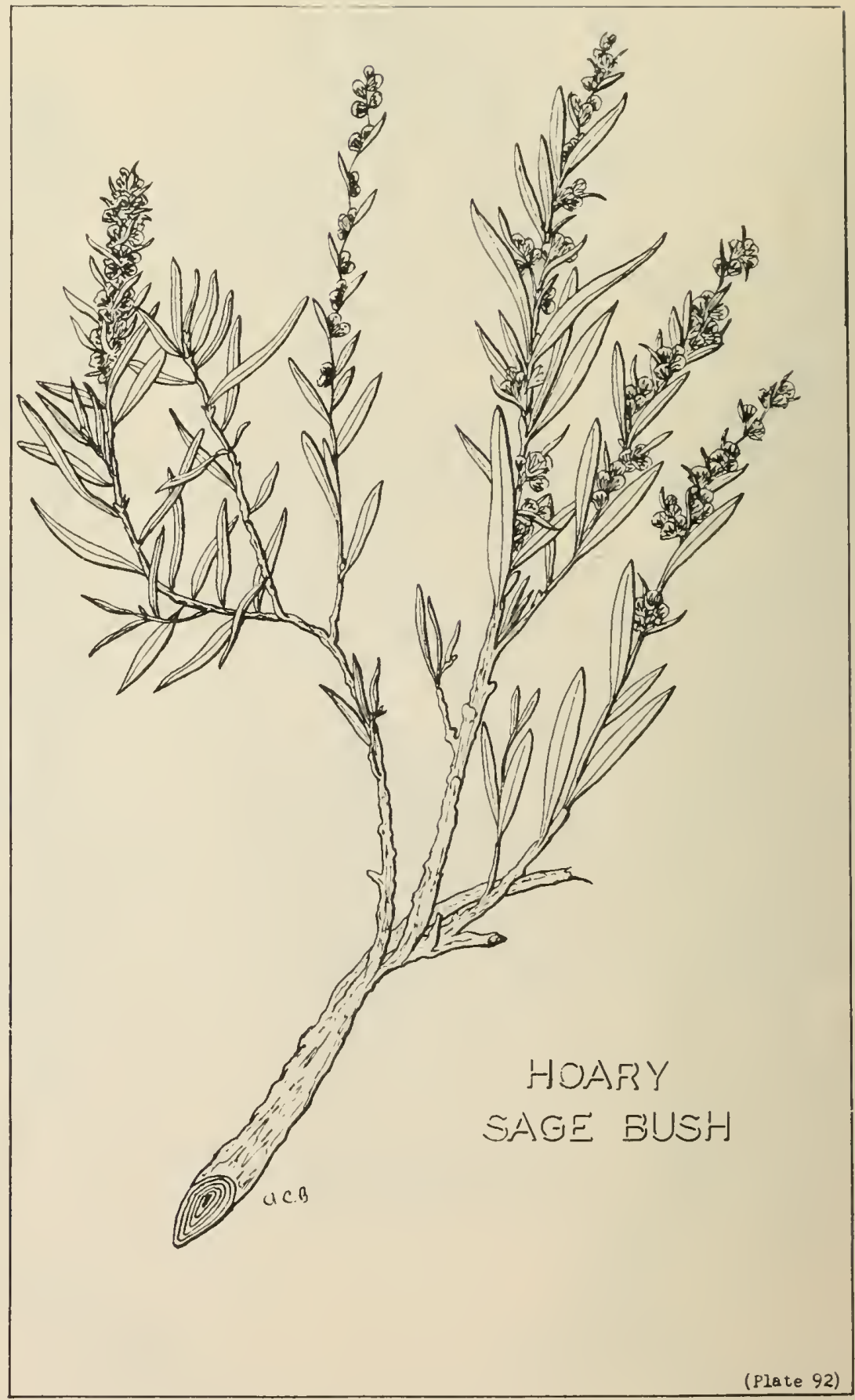


The common low growing sage of the prairies has been called pasture sage for many years. Probably fringed sage is a more descriptive name because its leaves are small, delicate, and lace-like. It has a wide range, occuring naturally in Northern Europe and Asia and throughout Western North America. The name "frigida" refers to the frigid regions in Siberia where the original collections were made.

Pasture sage has a perennial root and crown, but most of its aerial growth is annual. It is a low plant which may extend from a central crown by perennial prostrate stems which root at points of contact with the soil. The woolly stems seldom exceed 15 inches in height and are crowded with small silvery leaves. Yellow flowers bloom from late July to early September and in dense stands give off clouds of pollen which may cause hay fever.

The forage value of pasture sage as determined by chemical analyses is very high. Protein, phosphorus, and fat, contents are well above those for the associated grasses in all stages of growth, in fact the protein content will equal that of good alfalfa. However, the presence of aromatic oils apparently limits its palatability because only during the autumn and winter will cattle graze the plant to any degree. Sheep eat it more readily and will pasture it from early autumn through the winter and until late spring.

In many areas the presence of heavy stands will indicate an overgrazed condition. Numerous viable seeds, drought tolerance, low palatability classification, as well as the ability to root from stems, are all factors which tend to increase stands of pasture sage as the associated grasses are depleted by heavy use. In

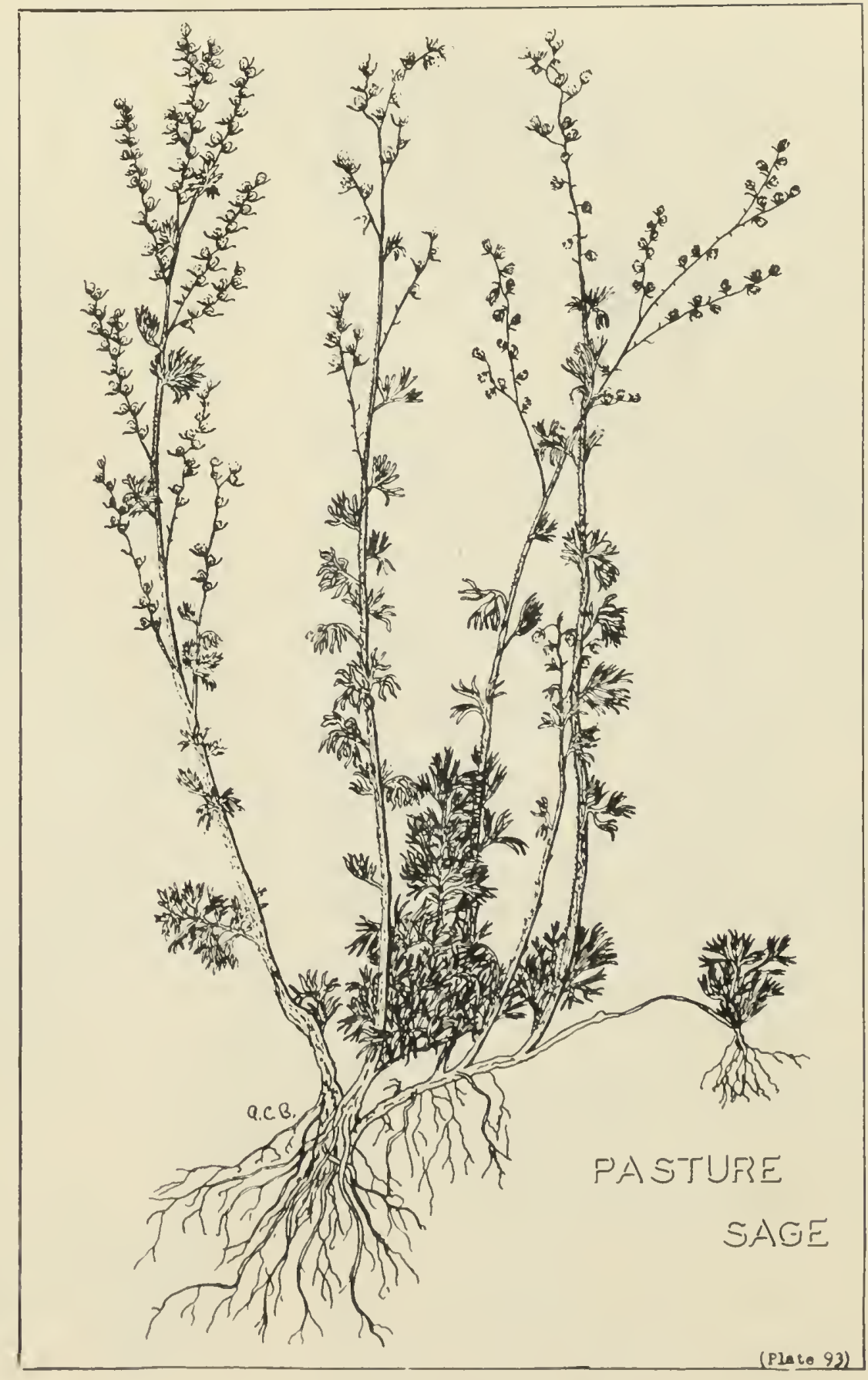

the mixed-grass prairie particularly, increasing stands indicate that overgrazing is being practised. 


\section{ASTERS}

\section{Aster spp.}

Aster means star and refers to the star-like appearance of the ray florets. In all probability it is the most numerous group belonging to the thistle family occurring in the Prairie Area as over twentyfive species have been identified and named. Because of their number, the species vary greatly in type of growth, flower color and size, and palatability.

Asters are usually perennial leafy herbs which grow from thick and often branched rootstocks. Stems may be numerous or solitary, and either herbaceous or woody. Usually there are several flower heads which may be less than $1 / 4$ inch across or more than 1 inch in diameter. However, all species will have flower heads composed of many florets, the rays will not number over fifty, and the bracts which enclose the flower will be in at least three rows.

The woody asters are not eaten, nor are those herbaceous forms with small white or blue flowers. As they have very definite habitats, usually around sloughs, they do not spread into the adjacent range. Thus they persist but lead very useless lives from an economic viewpoint.

Only one native aster can be rated as highly palatable. It has been named showy aster, $A$. conspicuus Lindl., because of large violet to blue flower heads which are often $1 \frac{1}{2}$ inches in diameter. It has a few large leaves up to 6 inches in length and a rough hairy stem. Not only is it palatable but it has a satisfactory balance, containing as much as 20 per cent crude protein and over 0.50 per cent of phosphorus prior to the flowering period. It is quite common throughout the Parkland region, Foothills, Cypress Hills, and Central British Columbia.

Smooth aster, A. Lindleyanus T. \& G., is palatable also, but is not eaten so readily as showy aster.

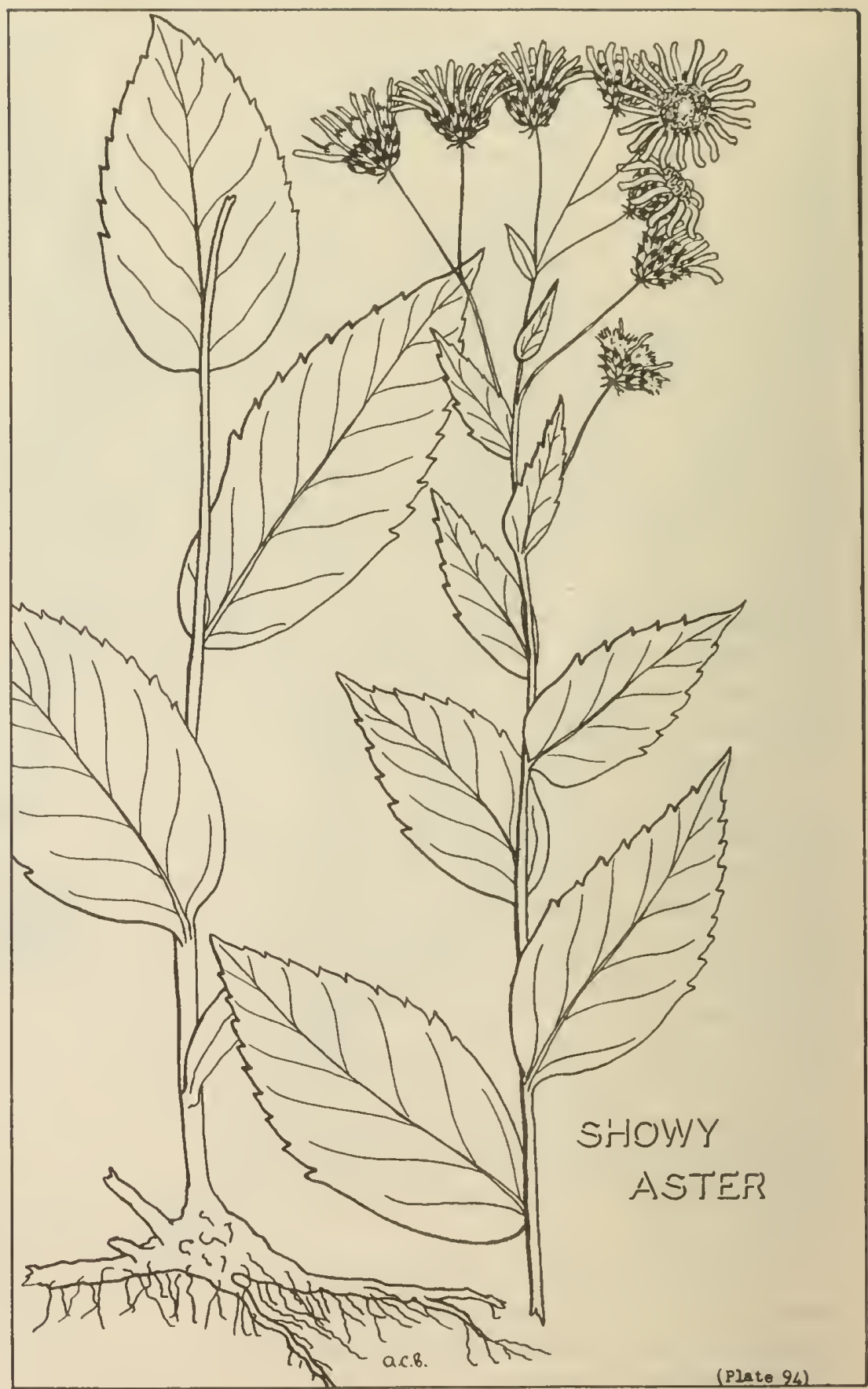

Whereas smooth aster will maintain itself and increase slightly with heavy grazing, showy aster will be grazed out. Smooth aster has a range similar to that of showy aster. 


\section{HAWKSBEARD}

\section{Crepis spp.}

There are seven members of the hawksbeard group found in the Prairie Area. They are members of the thistle family with the typical flower head composed of a number of florets. The milky sap is a character which it has in common with dandelion. No one of the species occurs throughout the region, each having a fairly local distribution or requiring specific growth conditions for its expression.

The native hawksbeards are perennial herbs with deeply penetrating woody tap roots. The toothed leaves are mostly basal, although a few much smaller leaves may occur on the 1- to 2-foot stems. Both leaves and stems are hairy but not woolly. The flowers are yellow in all species and usually in groups of three to five, each about 1 inch across. A European annual has invaded the eastern portion of the Prairie A rea; it differs from the native species by having smaller and more numerous flower heads.

Hawksbeards are palatable to all classes of livestock. Sheep will overgraze, stands to a point that all the plants will be killed out. Cattle make fair to good use and horses will eat them readily. Deer and elk are reported to eat them to almost the same degree as do sheep.

Unfortunately, hawksbeards do not grow in dense stands. They appear instead as scattered plants amongst the associated grasses. Although they do not produce an abundant supply of forage, their fairly dense basal leafage assures a good bite for the grazing animal. Their principal habitat is open woods and meadows at the northern

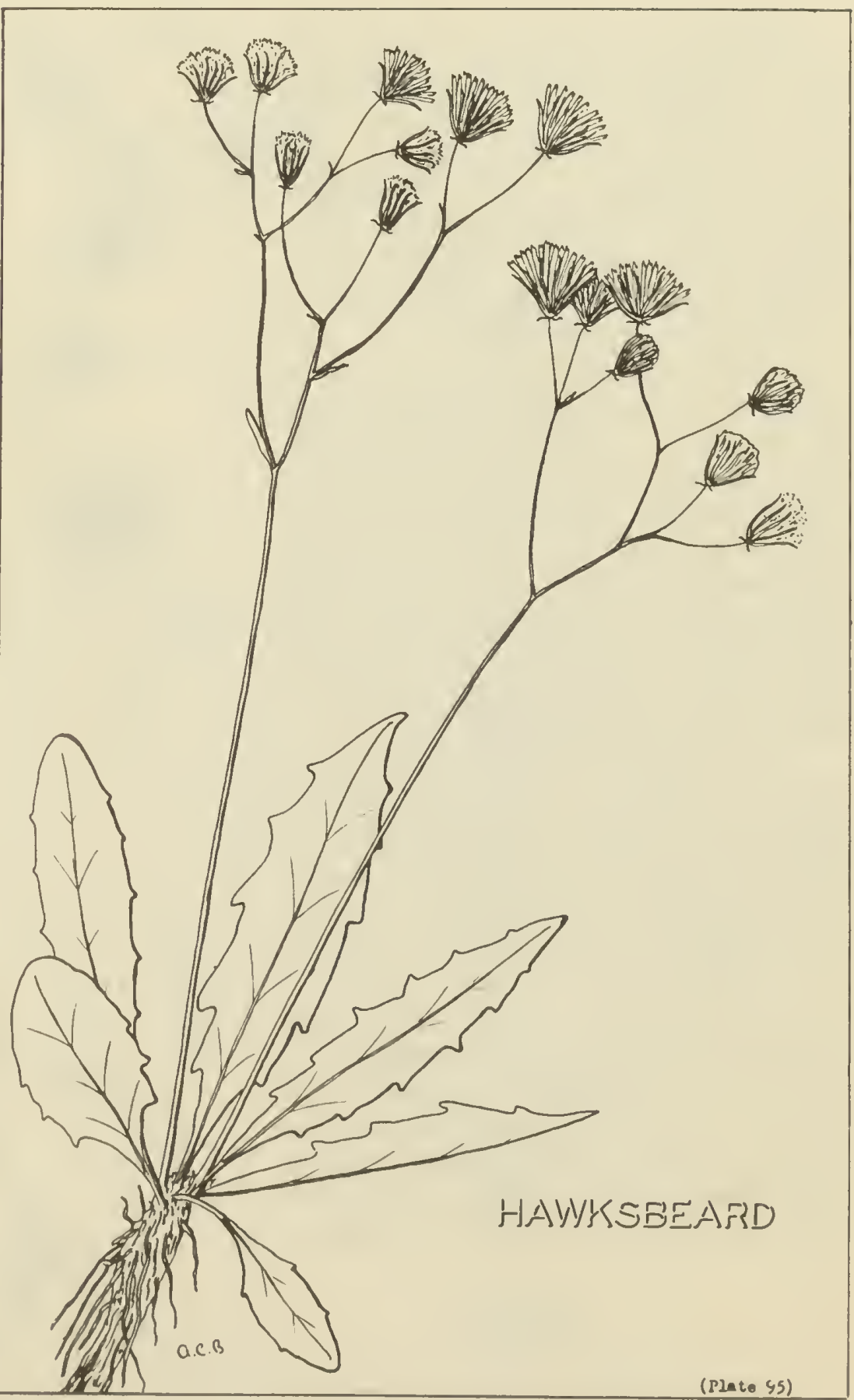
boundary of the region, but one species which grows in moist saline flats may be found any- where within the Prairie Area. 


\section{COMMON HAWKWEED}

Hieracium scabriusculum Schw.

Common hawkweed is the most abundant species of the seven hawkweeds which occur within the Prairie Area. Not only is it the most abundant, but it is also the most widespread as all other species have local distributions. The generic name Hieracium is derived from the Greek word meaning "hawk". It has a milky sap and is a member of the thistle family.

Common hawkweed grows from a stout rootstock. Its stem is unbranched except at the top where short branches end in flower clusters. The leaves are sparsely toothed with their bases clinging to the stem. Both stem and leaves contain a milky sap and both are covered with dense short white hairs giving the plant a woolly appearance. Flower heads are yellow in color, about 1 inch across, and contain ray florets with a square toothed tip.

All classes of livestock graze hawkweed, although sheep utilize it to the greatest extent and horses the least. All parts of the plant are eaten. While the leaves and flowers are the most palatable to domestic livestock, deer and elk will graze all parts readily.

Other native hawkweeds resemble common hawkweed in most characters. All species have a woolly appearance, all have cream-colored or yellow flowers, and all have entire or very sparingly toothed leaves. None of these species are abundant and none have widespread distributions.

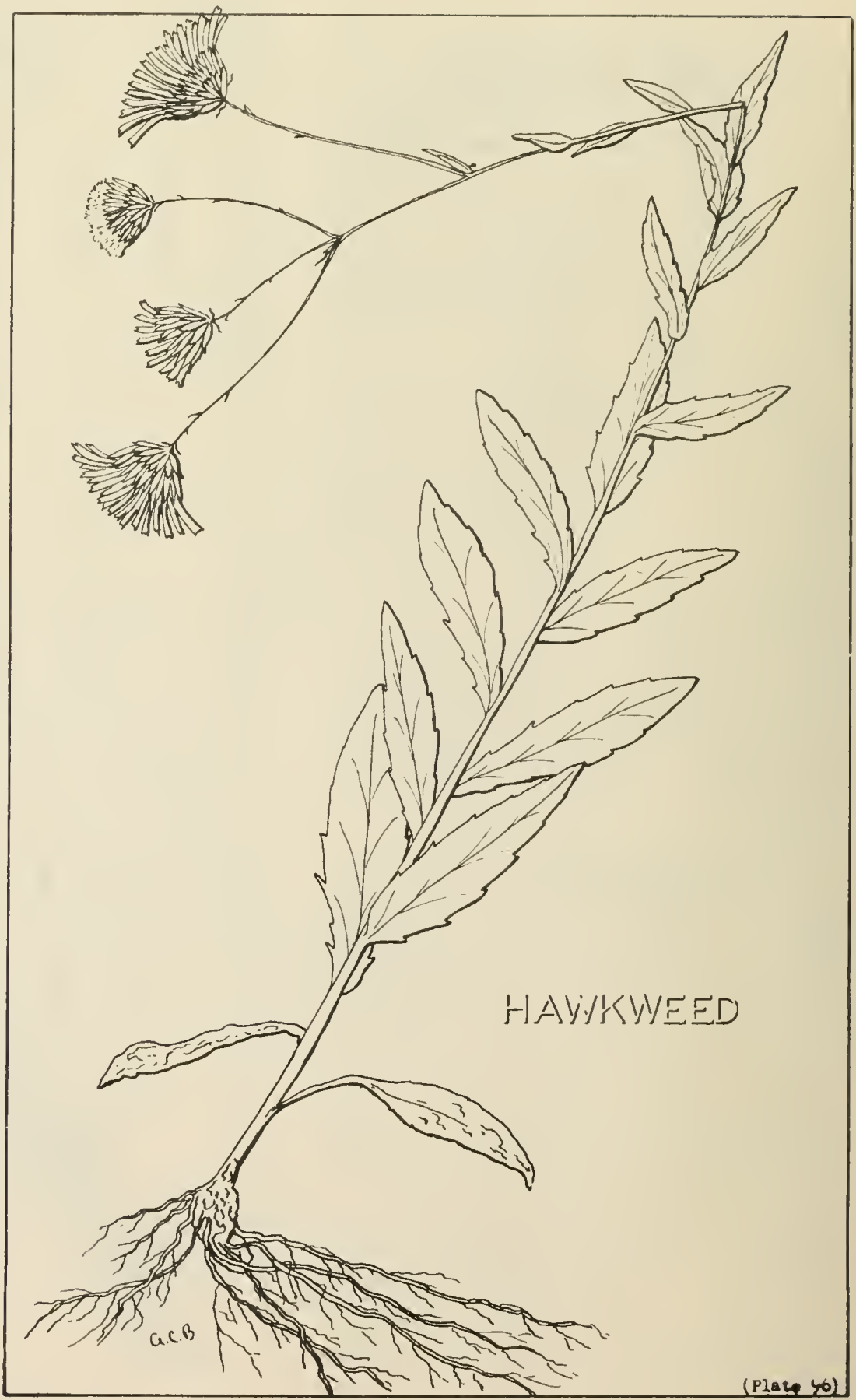




\section{SOW-THISTLE}

Sonchus arvensis $\mathrm{L}$.

Sow-thistle, a member of the thistle family, is an introduced weed coming originally from Europe. It found many sites where growth conditions favored its establishment, and its aggressive and rapidly spreading characters soon caused it to be recognized as an important noxious weed of cropland. In the Prairie Area it spread rapidly through the Portage Plains and Red River Valley before 1920 and more slowly westward throughout the Parkbelt. It moved into the drier portion of the region during the late 1930's and established itself in small patches in favorable locations. Sow-thistle grows from vigorous, creeping, white rootstocks which are from 4 to 10 inches below the surface of the ground. Hollow stems up to 5 feet in height have large and numerous leaves which have lobes that point backwards. The showy yellow flowers may be as much as 2 inches in diameter and grow in clusters at the top of the stem. An acrid milky juice can be squeezed from all parts of the plant.

As with many other members of this family, sow-thistle is grazed readily provided the stands are not too large. Individual plants or even small patches may be eaten but large stands will not be touched to any degree. However, it is an early growing plant and thus often adds to forage supplies before associated grasses come into strong production. Sow-thistle has a marked laxative effect on cattle.

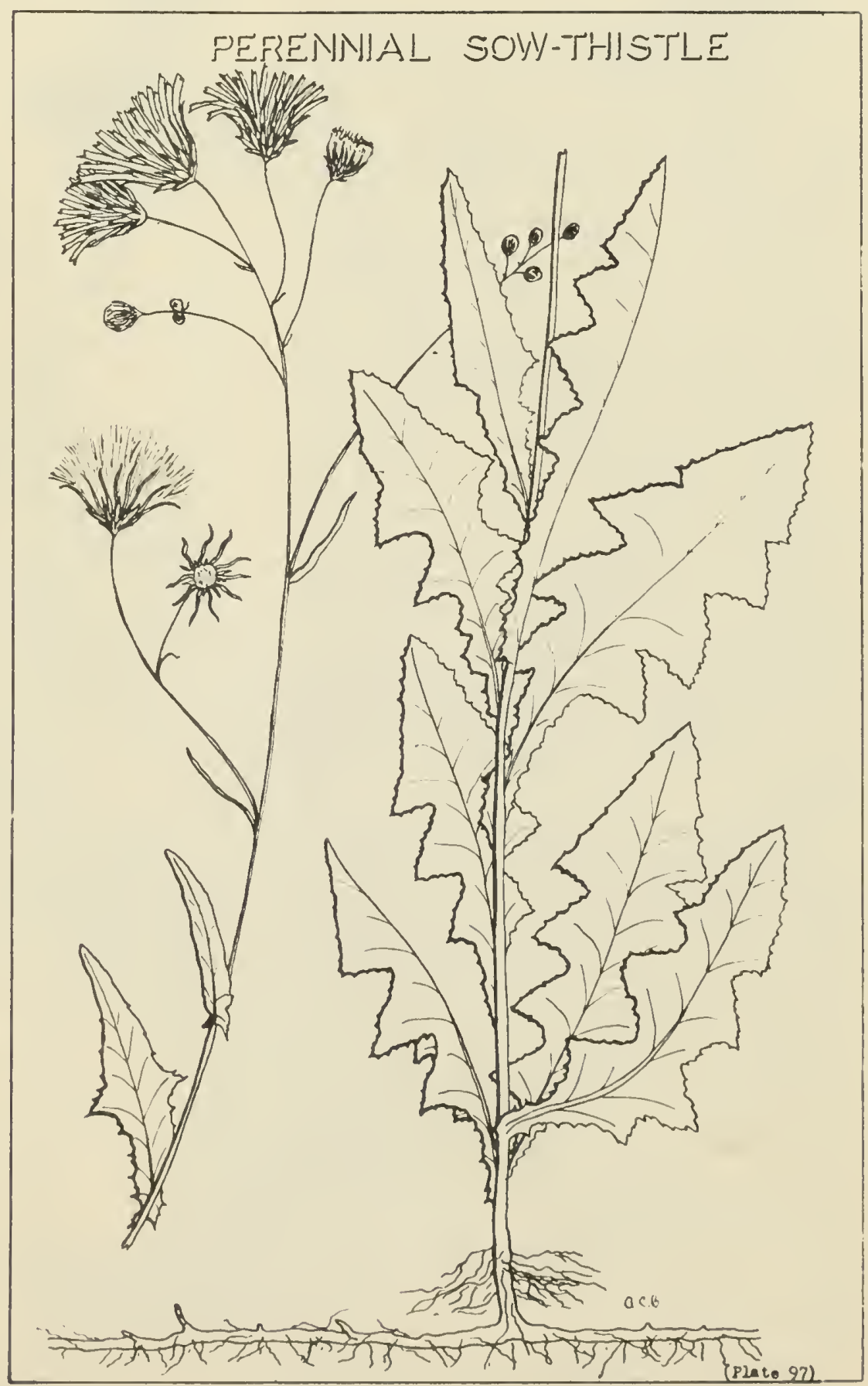




\section{DANDELION}

\section{Taraxacum officinale Weber}

Dandelion is likely the best known and the most widespread plant throughout the world. It will grow on a variety of soils, but prefers moist meadows; it will grow under a wide range of climate, although it prefers moderate conditions. It has spread from Europe throughout the settled portions of both the northern and southern hemispheres. The name dandelion means "lion's tooth" and refers to the deeply cut and backward-pointing segments of the leaves. Dandelion is a member of the thistle family.

Dandelion grows from a deep fleshy tap root. There is no stem and both the numerous leaves and the flower stalks grow directly from the crnwn. The leaves are deeply cut, they may stand erect when growing in shady places or cling to the ground when growing amongst short grass. A single yellow flower head grows at the tip of the hollow flower stalk. Both the leaves and the flower stalk contain an acrid milky sap.

Dandelion is palatable to all classes of livestock and particularly so to sheep. Because dandelion makes an early growth and continues to produce leaves throughout the summer and until late fall, this plant is one of the few herbs which provide forage throughout the growing season. Its abundance may be an indicator of overgrazing in certain areas, but it might also indicate a lack of mineral balance in the soil. Dandelion is considered to be one of the best bee pastures during the early summer, one of the good characters which helps to offset its reputation as a weed of lawns and pastures.

A close relative to the common dandelion is the red-seeded dandelion. It differs principally in leaf shape and color of seed. Its leaf has a small end segment and its seeds are red, whereas

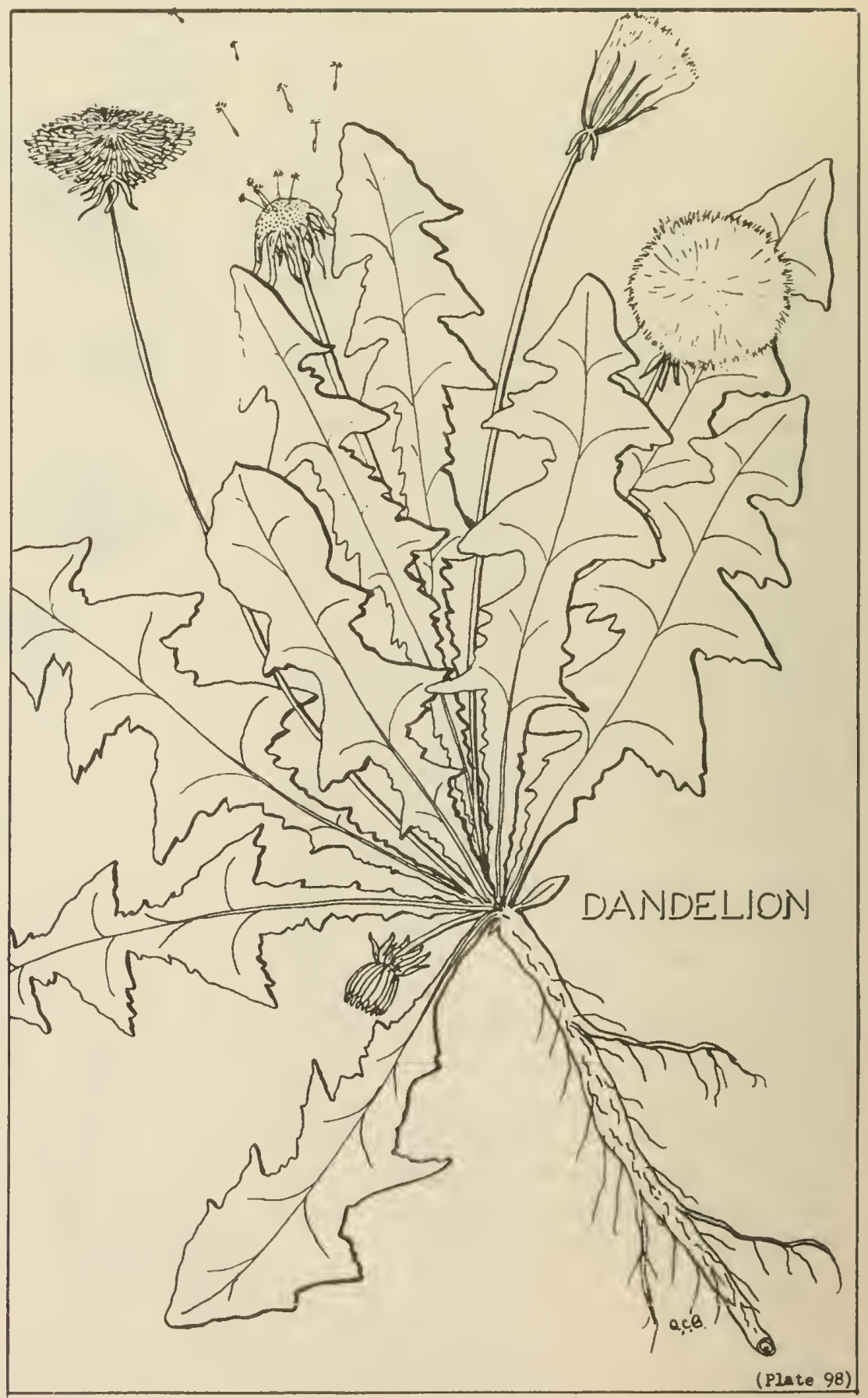

common dandelion leaves have large end segmenis and its seeds are brownish. Both occur everywhere throughout the Prairie Area and both are quite resistant to grazing. 


\section{GROUNDSEL, RAGWORT, OR BUTTER WEED}

Senecio spp.

The Senecio genus or group is a section of the thistle family. It is one of the largest groups of plants known, a total of over 2600 being reported from various places throughout the world. These species have a great variety of growth forms, from giant herbs and shrubs and moderate-sized trees in the equatorial zone of Africa to small herbs in the mountain area of Western Canada. Some fifteen species occur in the Prairie Area. Of these, three or four are palatable and one, an invader from Europe, is reported to be poisonous to cattle and horses.

Although the groundsels superficially resemble many other members of the thistle family, the single row of bracts which enclose the flower head can be used as a character to distinguish this group from others. These bracts are strap shaped with a lance-shaped tip. The leaves are alternate, usually entire or sparsely saw-toothed, although those of the reputedly poisonous species, tansy ragwort, S. Jacobaea L., are deeply dissected into three or four segments.

One or more of the groundsels may be found anywhere in the Prairie Area. One of the most common is marsh ragwort, $S$. $p a$ lustris (L.) Hook., which often forms dense communities around sloughs and lakes and along streams; it is fairly palatable to sheep, but is rated as poor fodder for cattle. Pursh's ragwort, S. Purshianus Nutt., is the most common species in the dry central portion. It is seldom grazed by cattle, but sheep eat it readily. The poisonous species, tansy ragwort, has been reported in the eastern edge of the Prairie Area at

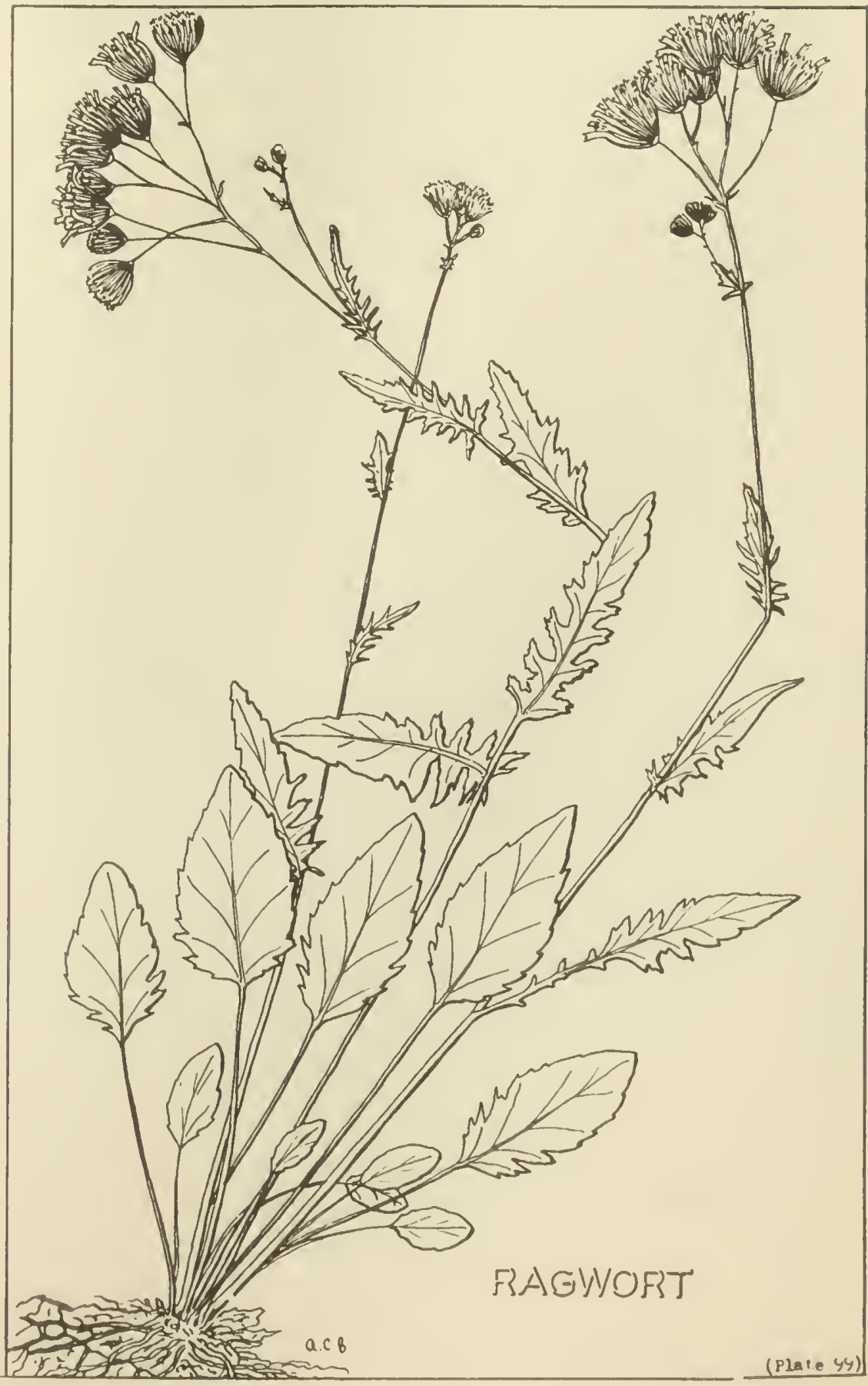

Swan River, Erickson, and Winnipeg. It is palatable and cattle feeding on it may develop a condition known

as Pictou disease. In all probability it will spread westward through the Parkland region. 



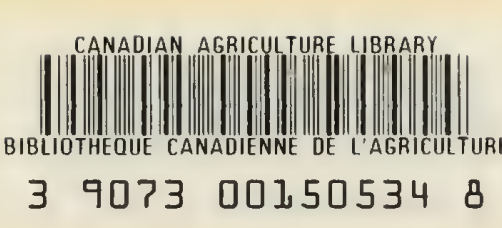


EDMOND CLOUTIER, C.M.G., O.A., D.S.P.

QUEEN'S PRINTER AND CONTROLLER OF STATIONERY OTTAWA, 1955 


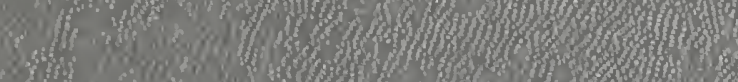

mongen 1. (6)

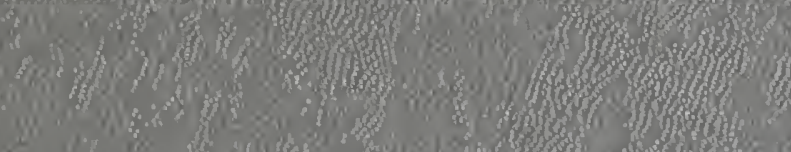

1.7.

H. 3
3

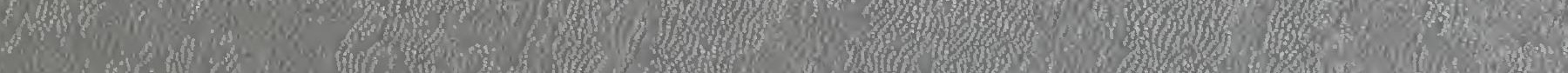

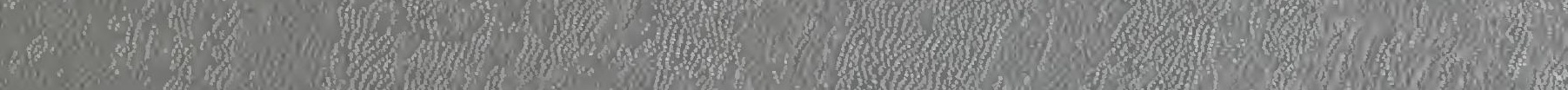

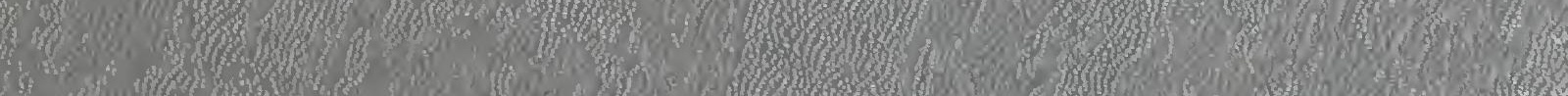

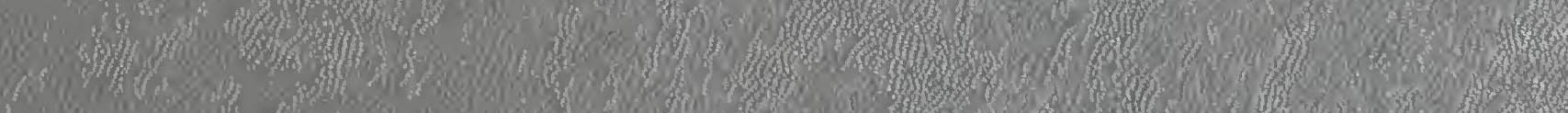
"W

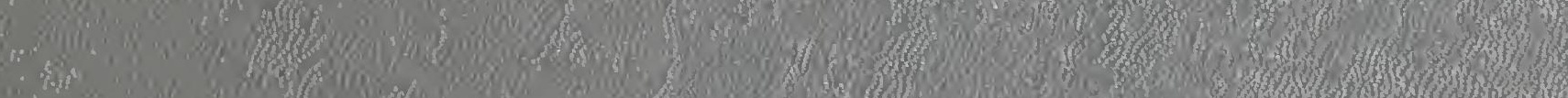

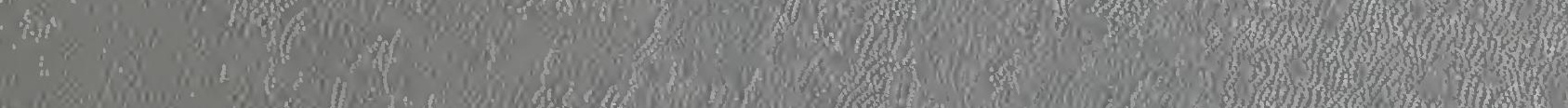

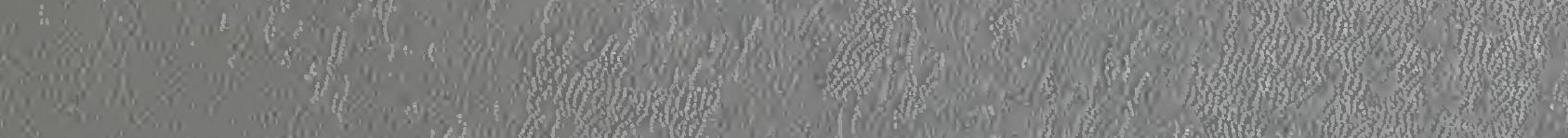

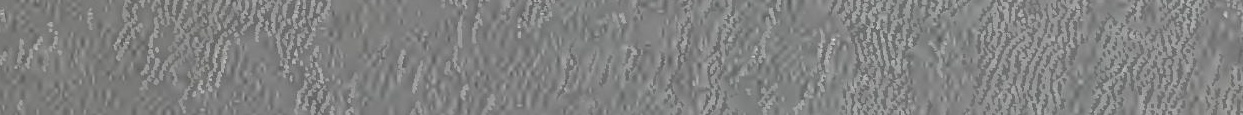
Som W. (1)

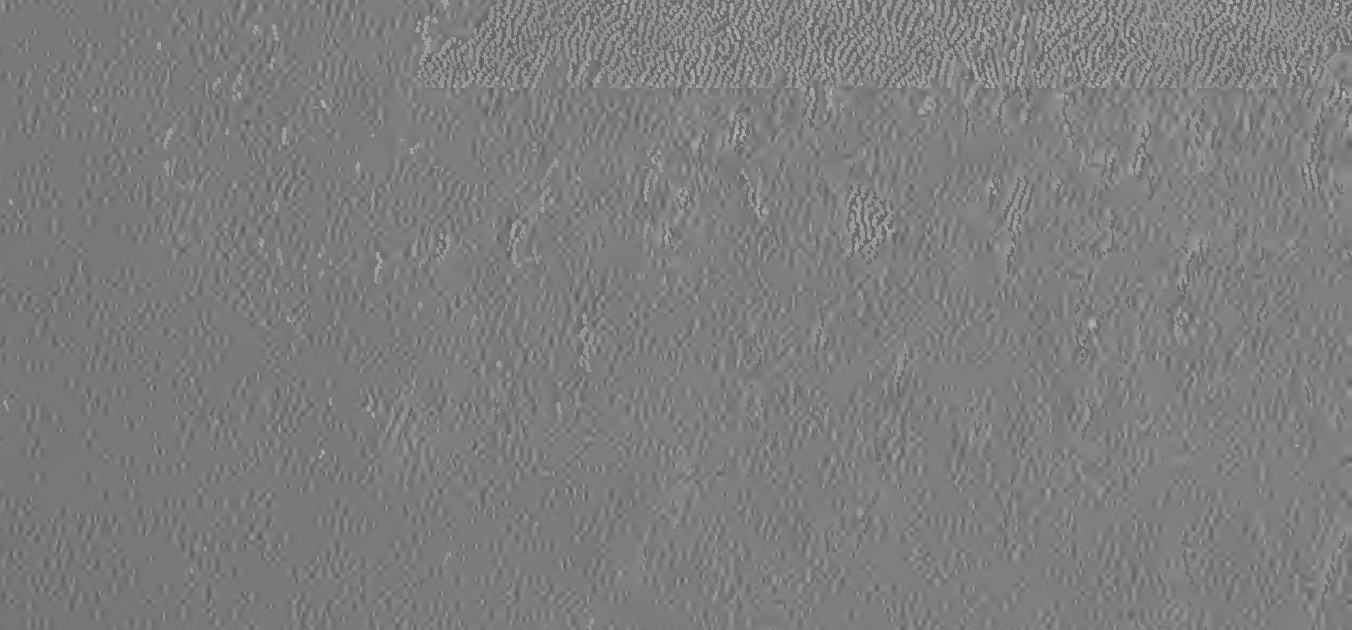

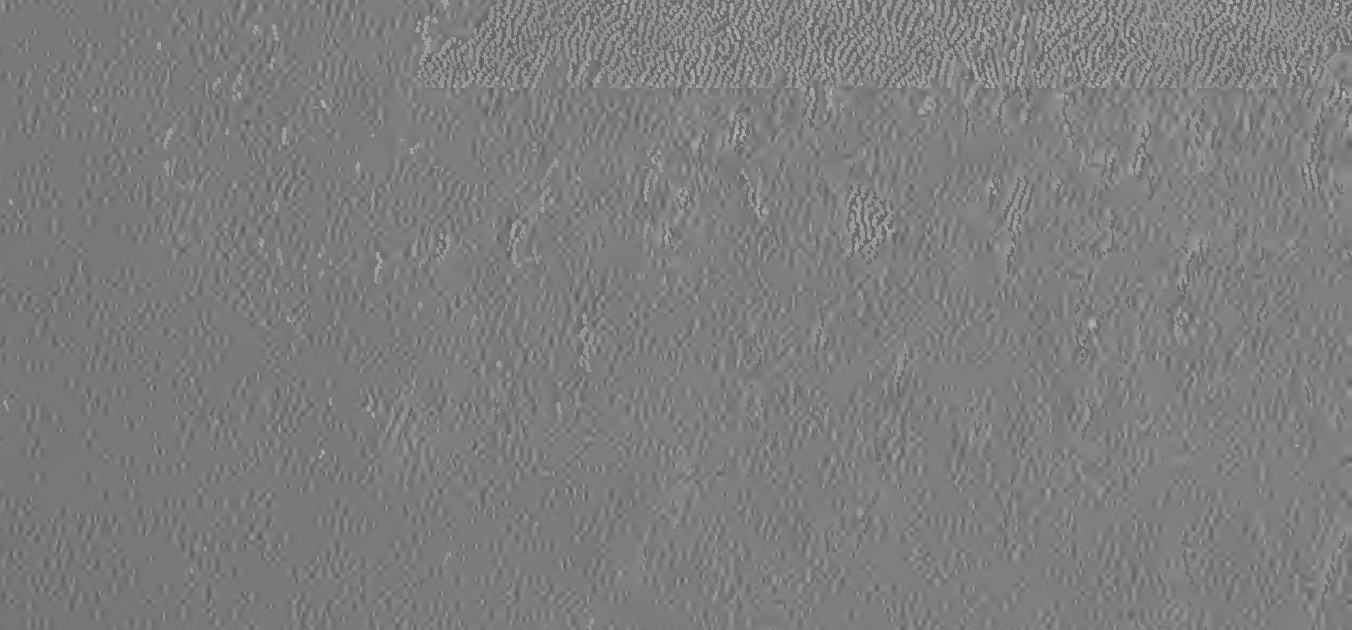

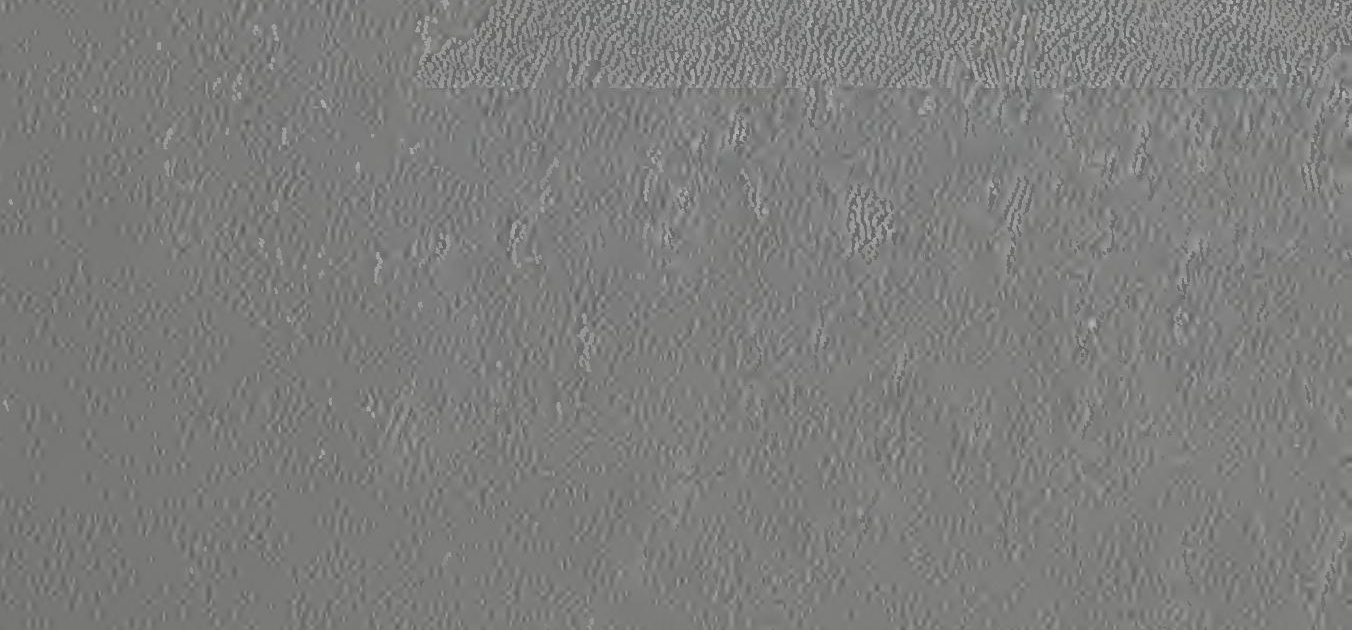

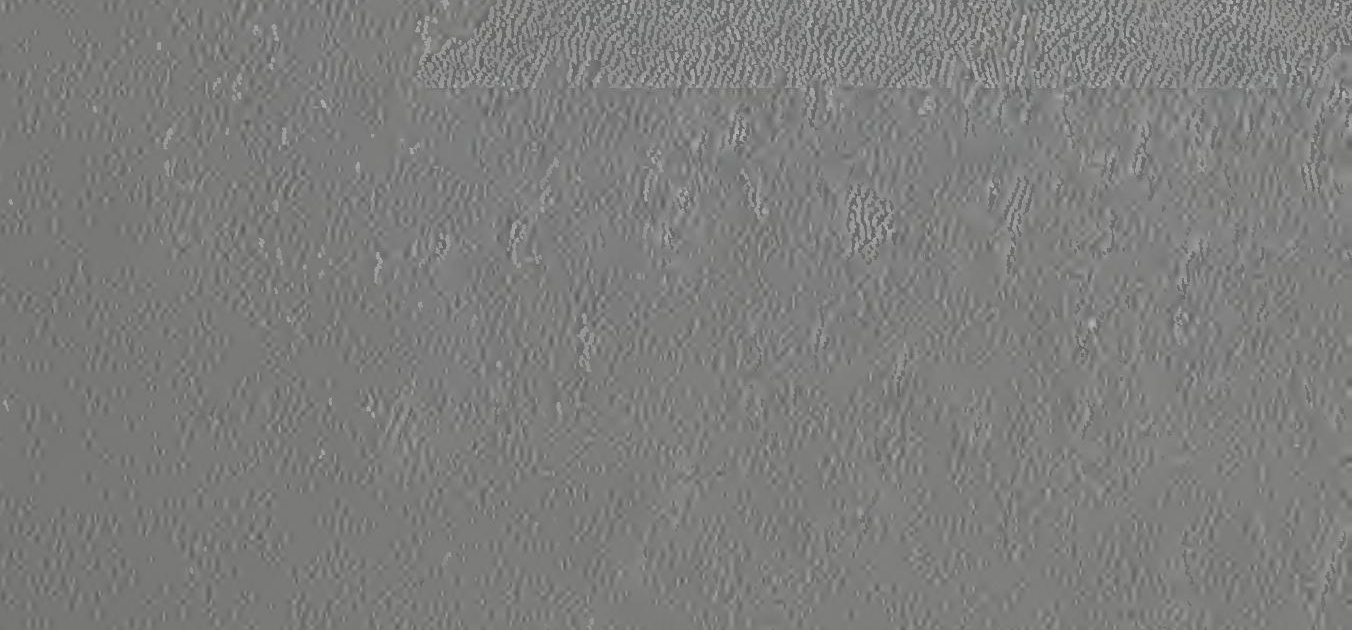

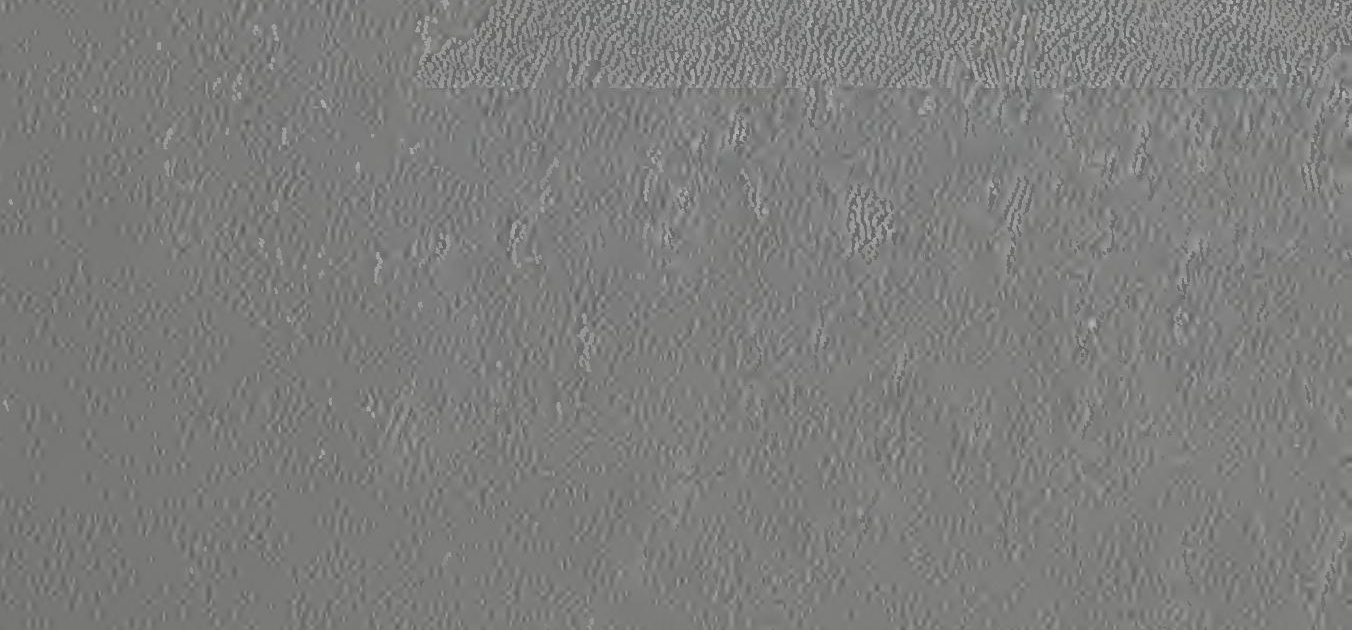

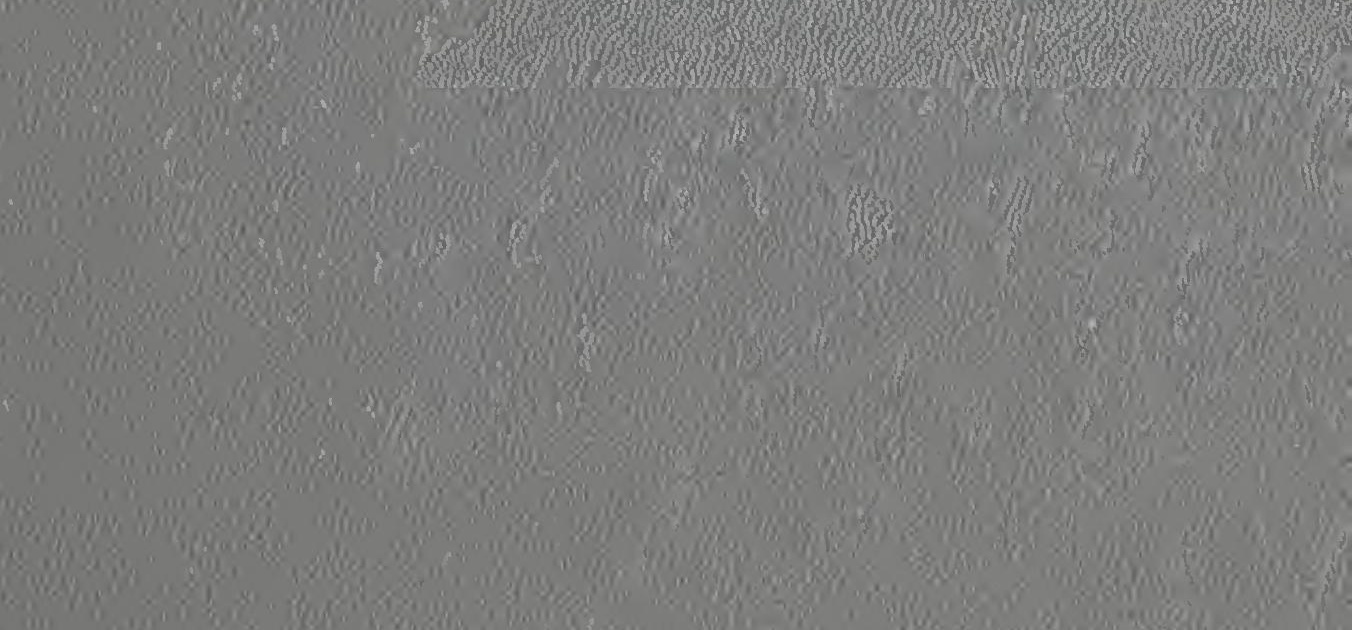

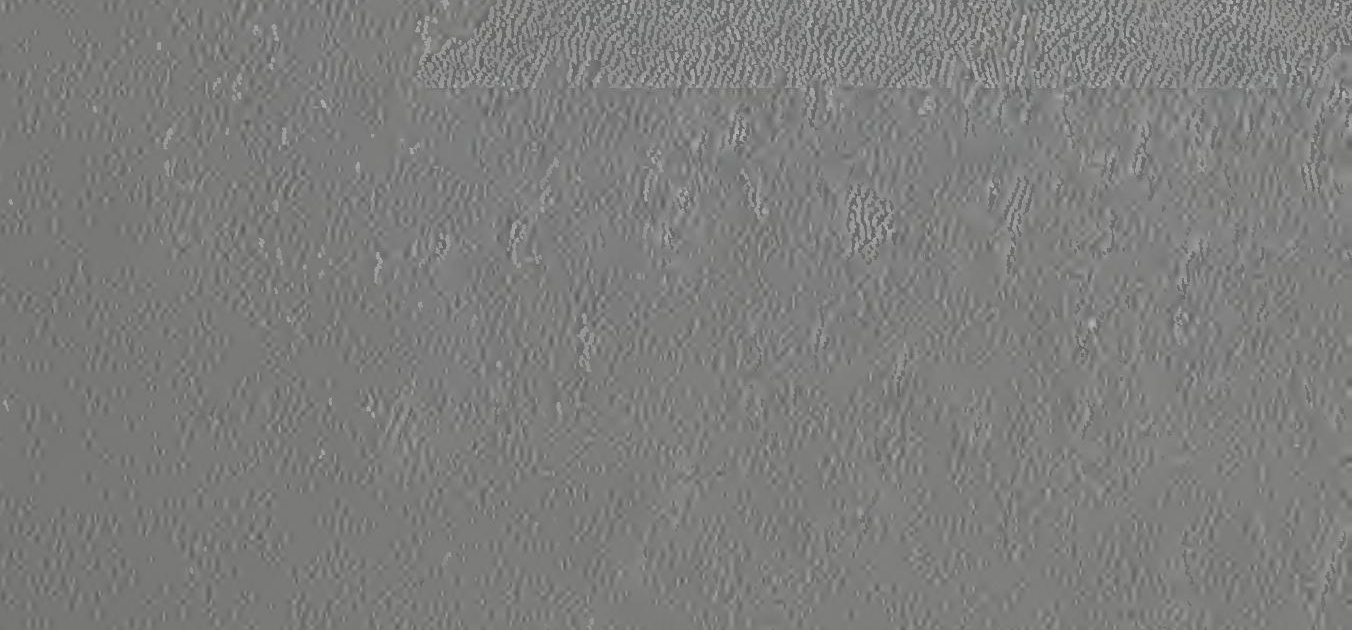

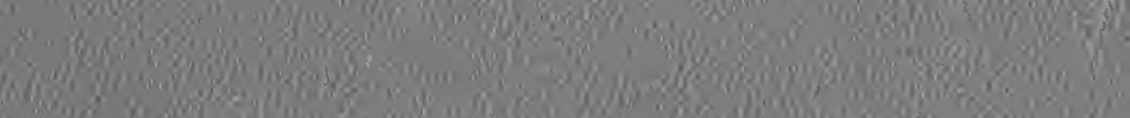

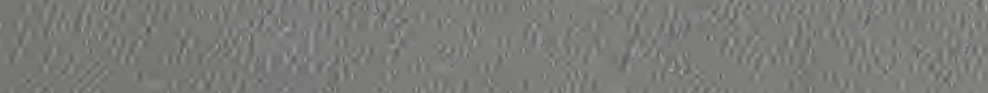
(x)
and
(N)
W.

Won Whe Q al wa 
